\title{
Sistemática e análise filogenética de Epiperipatus Clark, 1913 baseada em dados moleculares e morfológicos (Onychophora: Peripatidae)
}

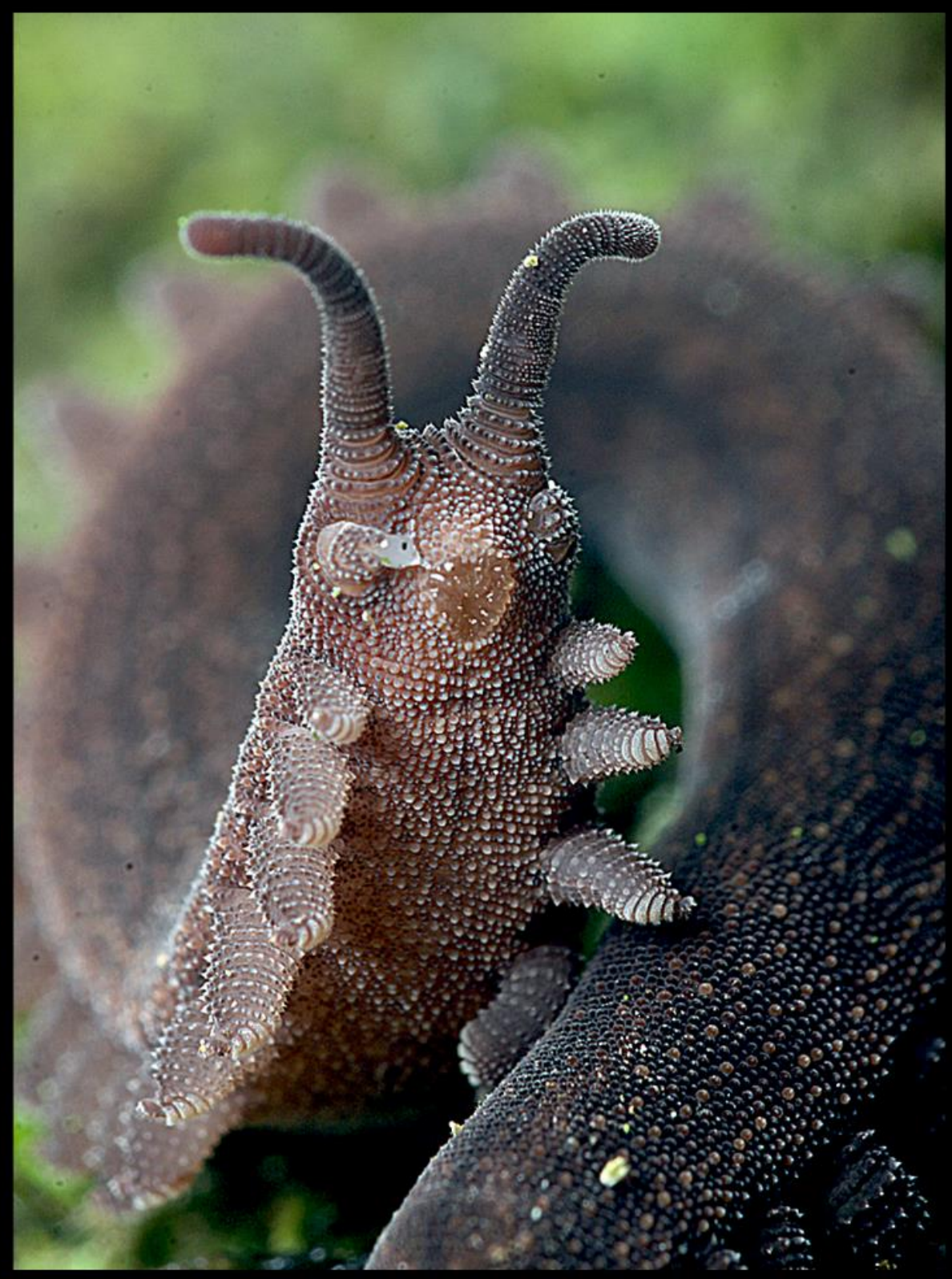

Instituto de Biociências

Unversidade de São Paulo 
Capa: Epiperipatus [sp 17] n. sp.,

por Flávio Uemori Yamamoto

Contracapa: papila oral de Eperipatus acacioi,

por Cristiano Costa 


\section{Cristiano Sampaio Costa}

\section{Sistemática e análise filogenética de Epiperipatus Clark,}

1913 baseada em dados moleculares e morfológicos (Onychophora: Peripatidae)

\section{Systematic and Phylogenetic analysis of Epiperipatus Clark, 1913 (Onychophora: Peripatidae) based on molecular and morphological data}

Tese apresentada ao Instituto de Biociências da Universidade de São Paulo, para a obtenção de Título de Doutor em Ciências, na Área de Zoologia.

Orientador: Dr. Ricardo Pinto da Rocha Coorientador: Dr. Fernando Portella de Luna Marques 
Costa, Cristiano Sampaio

Sistemática e análise filogenética de Epiperipatus Clark, 1913 baseada em dados moleculares e morfológicos (Onychophora: Peripatidae)

999 páginas

Tese (Doutorado) - Instituto de Biociências da Universidade de São Paulo. Departamento de Zoologia.

1. Onychophora 2. Peripatidae 3. Epiperipatus 4. Revisão sistemática. I. Universidade de São Paulo. Instituto de Biociências. Departamento de Zoologia.

\section{Comissão Julgadora:}

$\operatorname{Prof(a).~Dr(a).~}$

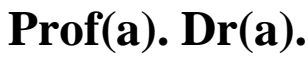

$\operatorname{Prof(a).~Dr(a).~}$

$\operatorname{Prof}(\mathbf{a}) . \operatorname{Dr}(\mathbf{a})$

Prof. Dr. Ricardo Pinto da Rocha 
"Without taxonomy to give shape to the bricks, and systematics to tell us how to put them together, the house of biological science is a meaningless jumble"

R. M. May, Nature 347:129-130, 1990 
A todos que de alguma maneira contribuíram com meu aprendizado ao longo da vida. 


\title{
Agradecimentos
}

\author{
Apoio financeiro
}

FAPESP, processos número 2011/20211-0, 2012-02969-6 e 2014/20557-2

\section{Apoio técnico e científico}

Lab. de Aracnologia, Dep. Zoologia, IB-USP

Lab. de Sistemática Molecular, Dep. Zoologia, IB-USP

Lab. de Histologia, Dep. Zoologia, IB-USP
Lab. de Microscopia Eletrônica, MZUSP

Giribet Lab, MCZ, Harvard University

\section{Instituições colaboradoras}

Evolution et Diversité Biologique Laboratory

Museu Nacional do Rio de Janeiro/ UFRJ

Museu Nacional da Universidade de São Paulo

Museum of Comparative Zoology

Natural History Museum, London

Universidad Autonóma de Chiriquí
Universidade Federal de Mato Grosso

Universidade Federal de Mato Grosso do Sul

Universidade Federal de Minas Gerais

Universidade Federal da Paraíba

Universidade Federal do Piauí

Universidad Nacional de Colombia

\section{Participações especiais}

Aldair de França Neto

Fabrício Sanguinetti Cruz de Oliveira

Manuel Antunes Júnior
Orlemir Carrerette dos Santos

Pedro de Souza Dias

Renato Mitsuo Nagata

\section{Agradecimentos especiais}

Prof. Dr. Gonzalo Giribet, pelo apoio e ensinamento constante enquanto participei do Giribet $l a b$.

Profa. Dra. Cibele Bragagnolo, pelo apoio e sugestões iniciais em meu projeto de doutorado.

Prof. Dr. Ricardo Pinto da Rocha, por aceitar o desafio de me orientar e pelas portas abertas. 
Prof. Dr. Fernando Portella de Luna Marques, pela coorientação e ensinamentos de valor incalculável.

Prof. Dr. Sérgio Antonio Vanin, pela consultoria jurídica em assuntos nomenclaturais e taxonômicos.

Aos alunos do Laboratório de Aracnologia/USP, pelo compartilhamento de conhecimento e amizade.

Denis Jacob Machado, pelo apoio nos últimos meses do meu doutorado e por sua dissertação que me serviu de inspiração.

Tarciana Barbosa, por todo apoio dedicado e o acompanhamento de cada passo. 
ÍNDICE

CAPÍTULO 1. INTRODUÇÃO GERAL ………………………………………………………………...... 1

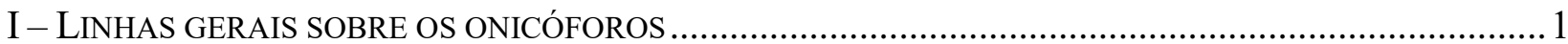

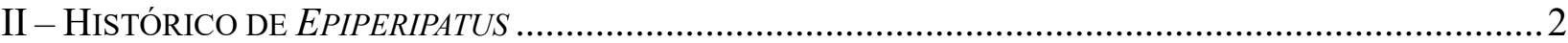

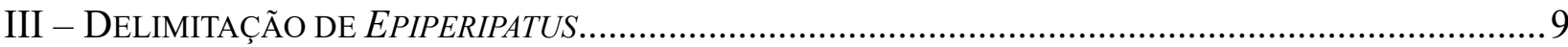

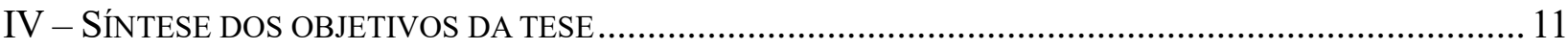

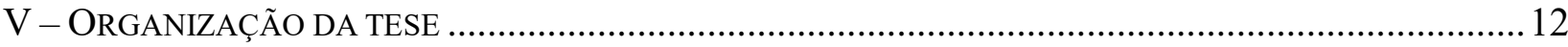

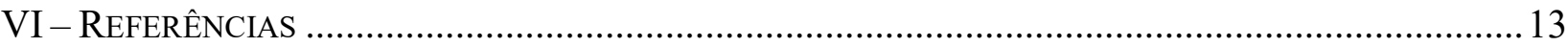

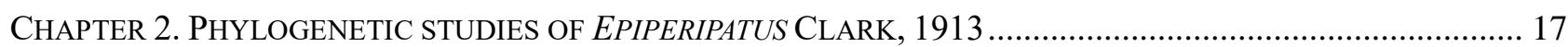

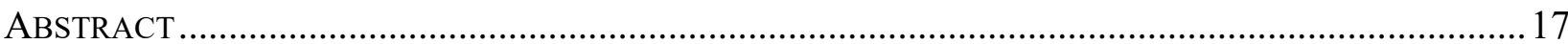

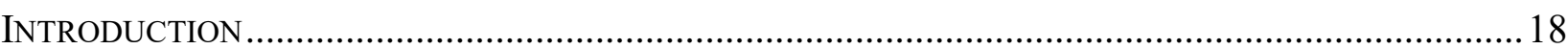

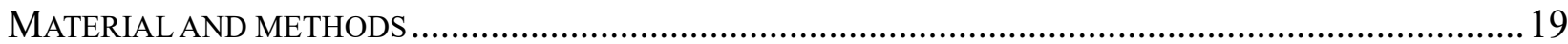

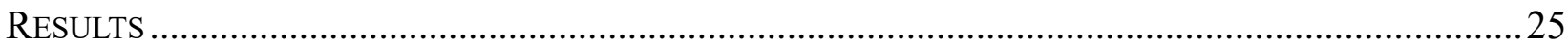

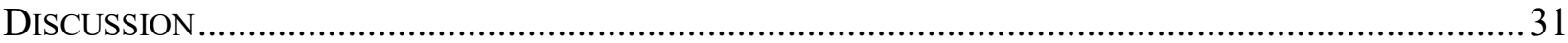

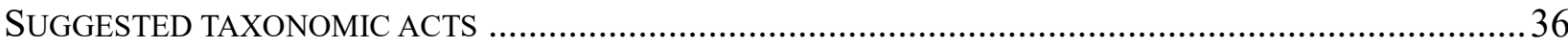

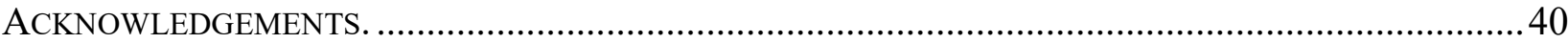

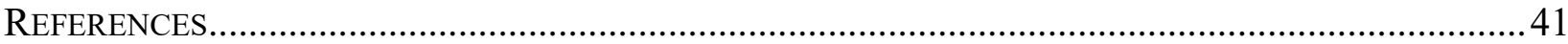

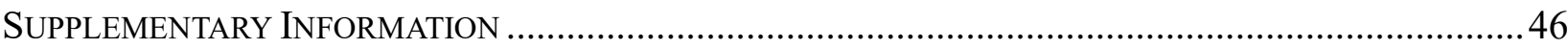

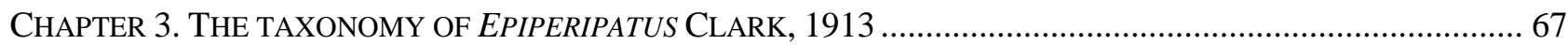

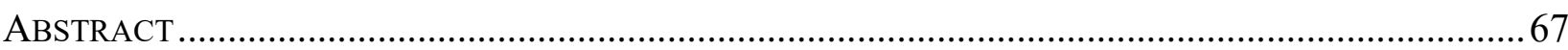

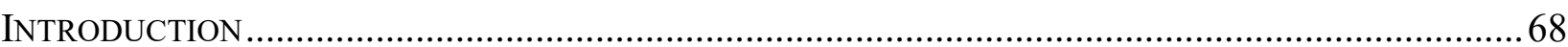

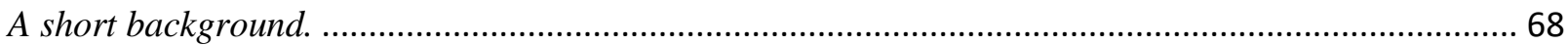

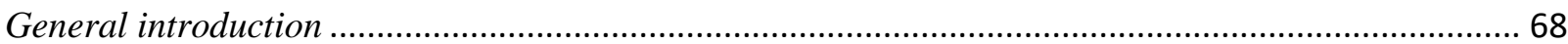

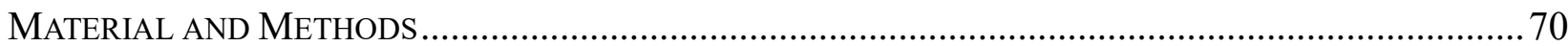

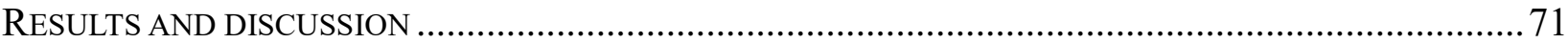

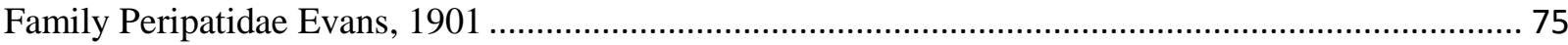

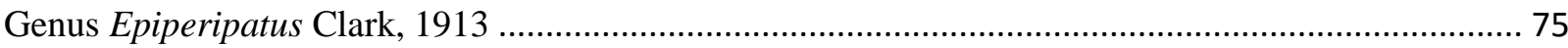

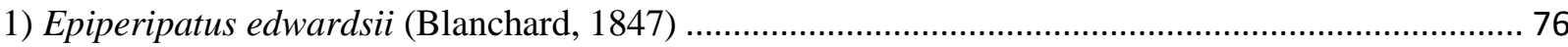

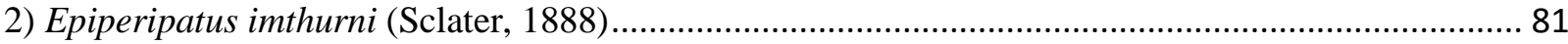




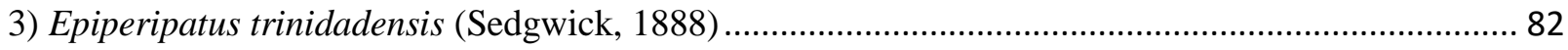

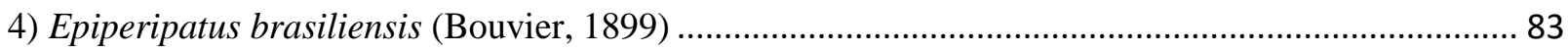

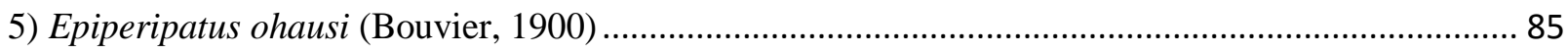

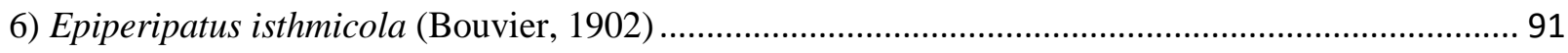

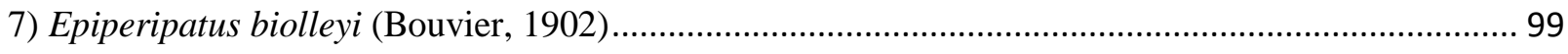

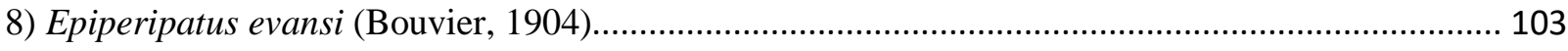

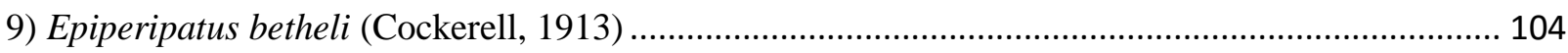

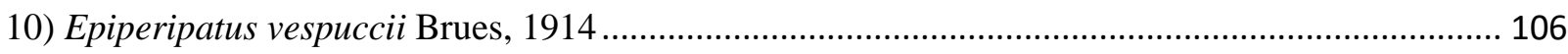

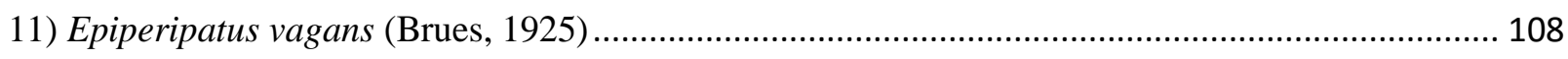

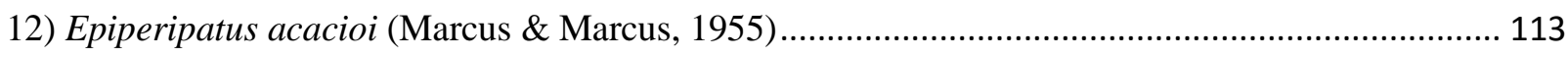

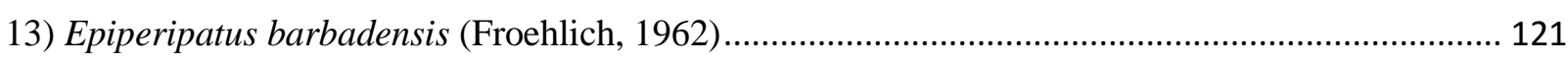

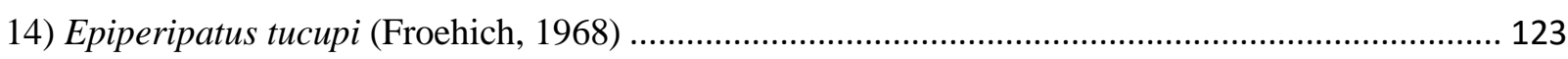

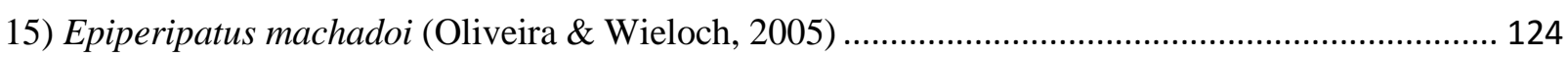

16) Epiperipatus cratensis Brito, Pereira, Ferreira, Vasconscellos \& Almeida, 2010 .......................... 133

17) Epiperipatus diadenoproctus Oliveira, Lacorte, Fonseca, Wieloch \& Mayer, 2011 ..................... 142

18) Epiperipatus adenocryptus Oliveira, Lacorte, Fonseca, Wieloch \& Mayer, 2011 ......................... 144

19) Epiperipatus paurognostus Oliveira, Lacorte, Fonseca, Wieloch \& Mayer, 2011 ........................ 146

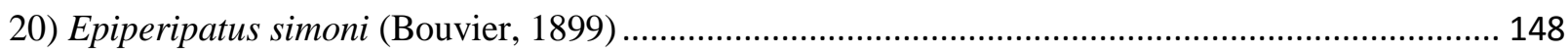

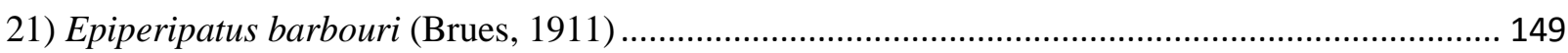

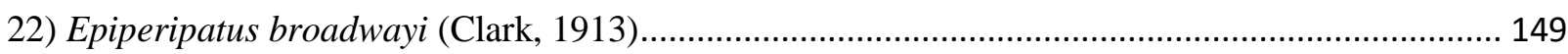

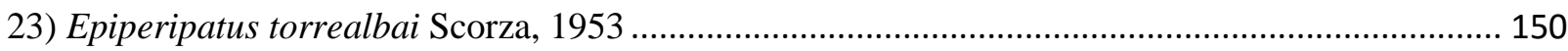

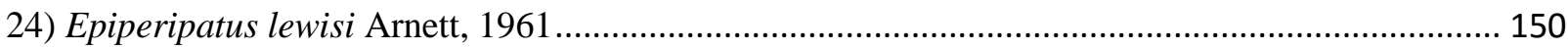

25) Epiperipatus hilkae Morera-Brenes \& Monge-Nájera, 1990 ....................................................... 151

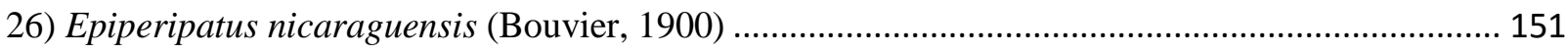

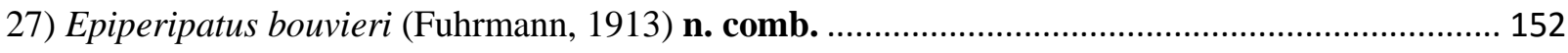

28) Epiperipatus solorzanoi (Morera-Brenes \& Monge-Nájera, 2010) n. comb.................................. 158

29) Epiperipatus hitoyensis (Oliveira et al., 2012) n. comb............................................................... 159

30) Epiperipatus sucuriuensis (Oliveira et al. 2015) n. comb.......................................................... 159

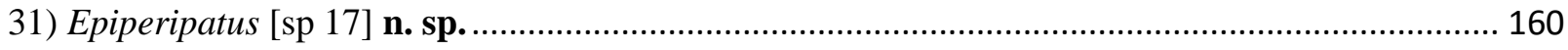

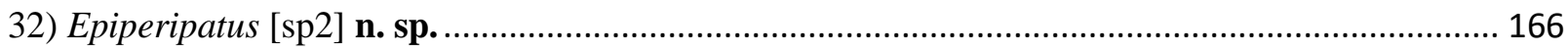

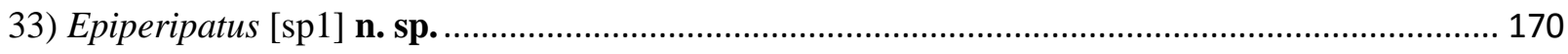

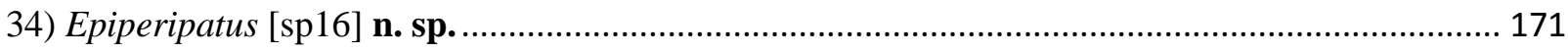

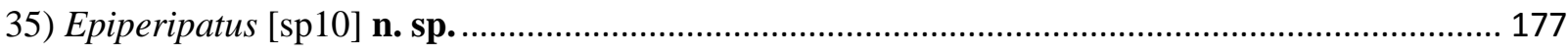

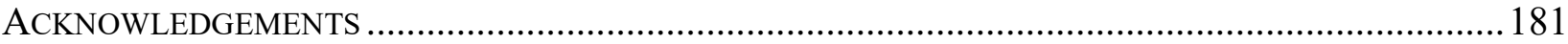

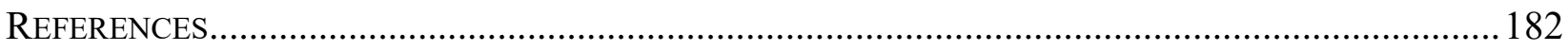




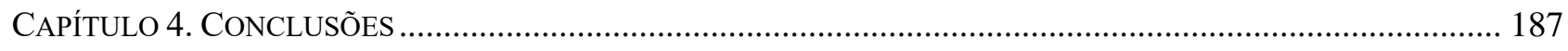

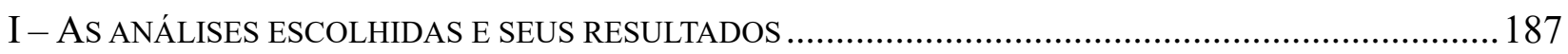

II - CONTRIBUIÇÃO DA MORFOLOGIA E DOS DADOS MOLECULARES PARA OS ESTUDOS

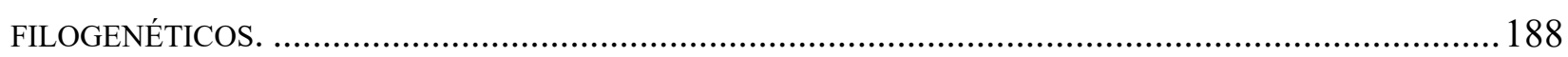

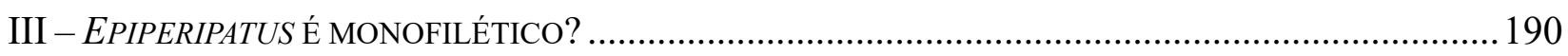

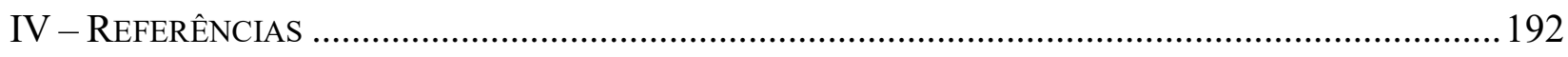

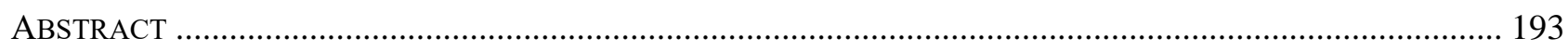

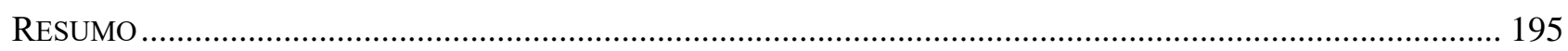




\section{Capítulo 1. Introdução geral}

\section{I - LINHAS GERAIS SOBRE OS ONICÓFOROS}

O nome Onychophora deriva do grego onycho, "garras", e phora, "portador", que em tradução literal significa aquele que porta garras (Brusca \& Brusca 2003). Não há um nome vulgar em português para esses animais, embora sejam chamados de perípato pelos biólogos. No entanto, sabese que em localidades isoladas no Norte do Brasil o nome "embuá de chifre" é associado aos onicóforos (Monge-Nájera \& Morera-Brenes 2015). O filo está dividido em duas famílias viventes (Peripatidae e Peripatopsidae) e quatro fósseis (Helenodoridae, Succinipatopsidae, Tertiapatidae, Tertiapatoidea). São conhecidas 197 espécies viventes (Oliveira et al. 2012).

Os onicóforos apresentam morfologia extremamente conservativa, o que constitui um fator complicante, especialmente em Peripatidae, para a organização taxonômica de seus gêneros e espécies. Peripatidae apresenta 12 gêneros, em torno de 76 espécies válidas e outras nove taxonomia duvidosa (Oliveira et al. 2012a, 2012b, 2013 e 2015). As espécies Neotropicais formam dois grandes grupos segundo Bouvier (1905): um grupo é aqui denominado como "andícola" e compreende todas as espécies encontradas ao longo da Cordilheira dos Andes e sua vertente ocidental. O outro grupo, chamado de "caraíba", reúne as espécies encontradas desde a vertente oriental dos Andes até as Antilhas. O grupo "caraíba" é o mais diverso, e abriga os maiores gêneros de Peripatidae: Peripatus Guilding, 1826 (com 21 espécies) e Epiperipatus Clark, 1913 (com 27 espécies).

Além de mais diversos, Epiperipatus e Peripatus são os gêneros que mais apresentam problemas taxonômicos, como compartilhamento de características e elevada variação morfológica inter e intraespecíficas. Esses são os fatores mais complicantes, uma vez que não são encontrados caracteres diagnósticos evidentes para delimitação de ambos os gêneros (Bouvier 1905, SampaioCosta et al. 2009, Read 1988, Oliveira et al. 2011). Epiperipatus e Peripatus são ambiguamente delimitados com base na morfologia das papilas dorsais e nas contagens de dobras dorsais por segmento, de escamas das papilas principais e de papilas crurais por perna pregenital (característica apenas dos machos). Mesmo assim, Peripatus e Epiperipatus receberam novas espécies nos últimos seis anos.

Em torno de $90 \%$ da diversidade de Peripatidae se encontra no neotrópico, e Peripatus e Epiperipatus possuem as distribuições mais amplas. Os outros $10 \%$ estão distribuídos na África e Malásia. Ambos os gêneros se sobrepõe na América Central, mas Epiperipatus destaca-se por apresentar mais espécies na América do Sul, principalmente no Brasil. Epiperipatus também chama 
a atenção por sua ampla distribuição, ocorrendo desde a Costa Rica (também ocorrendo nas Antilhas) descendo até a América do Sul, onde se distribui pela Colômbia, Venezuela, Guiana, Suriname, Guiana Francesa e Brasil (Brues 1914, Sampaio-Costa et al. 2009, Oliveira et al. 2012a).

\section{II - HISTÓRICO DE EPIPERIPATUS}

O primeiro onicóforo descrito foi Peripatus juliformis Guilding, 1826, coletado em Saint Vincent, atual Saint Vicent and Granadinas, nas Pequenas Antilhas (Guilding 1826). A espécie foi determinada como um molusco inicialmente, pertencente à classe Polypoda. O gênero foi caracterizado pela forma do corpo e das antenas, ausência de escudo (Guilding provavelmente se referia à concha dos moluscos), forma da boca, presença da mandíbula, tipo e cor dos olhos, posição do ânus e do orifício genital, número de lobópodes e aparência das garras. Para delimitar a espécie, Guilding utilizou-se da coloração dorsal e ventral do espécime, aspecto dorsal do corpo, especificando a presença das papilas e da linha média.

A descrição de Peripatus edwardsii foi apresentada por Blanchard (1847), que re-examinou um espécime coletado em Cayenne (Guiana Francesa), pré-identificado como P. juliformis por Jean Victor Audouin e Henri Milne-Edwards. Blanchard concluiu que a espécie de Cayenne era nova, pois, comparada com $P$. juliformis, apresentava menor número de pares de lobópodes, e a nomeou como P. Edwardsii (grafia original).

Moseley (1879) fez um histórico sobre as espécies de Peripatus para criticar a taxonomia dos onicóforos da época. Para esse autor as descrições eram consideravelmente confusas. Por isso, apenas uma análise cuidadosa de pequenas estruturas encontradas nos pés, tegumento e órgãos poderia fornecer resultados satisfatórios. Por exemplo, Moseley chamou a atenção para as papilas orais, comumente confundidas e contadas como apêndices locomotores, e comentou: "Hence some mistake may occur in the counting of the number of the feet in the various species" (Moseley 1879: 265).

Ernst (1881) analisou cinquenta e três exemplares oriundos do campus da Universidade de Caracas, Venezuela, discorrendo sobre dimorfismo sexual, a morfologia externa e detalhes da morfologia interna. Ernst estudou a anatomia e a quantidade dos arcos antenais, mandíbulas e aparelho reprodutor de machos e fêmeas. Dentre os exemplares, Ernst identificou Peripatus edwardsii, mas conclui seu trabalho da seguinte maneira: "I cannot conclude these remarks without confessing that I am not at all quite sure whether our Peripatus is really P. edwardsii as the figure of this species in Nicholson's "Manual of Zoology" (5th edit. p. 315), which is said to be after Grube, does not agree well with my living specimens." (Ernst 1881: 448). 
Sedgwick (1888) publicou a primeira revisão sobre onicóforos e sugeriu agrupar as espécies de acordo com quatro grupos mundiais: Sul Africana, Australiana, Neotropical e Sumatra. Nesse trabalho Sedgwick advertiu sobre a inacurácia dos resultados de autores pretéritos. Além disso, Sedgwick considerava os onicóforos como prototraqueados, que possuem afinidades com os anelídeos. Nesse trabalho, Sedgwick fez críticas às características taxonômicas do grupo. Por exemplo, não havia correspondência entre o número de pares de lobópodes presentes nas descrições de espécies e os espécimes examinados por ele. Por isso, Sedgwick reforçou à necessidade de uma revisão taxonômica das espécies de onicóforo. A monografia de Sedgwick (1888) é um marco na taxonomia dos onicóforos, pois há uma proposta de utilização conjunta de caracteres internos e externos (apresentadas em pranchas detalhadas). Além disso, foi aprimorada a descrição do gênero Peripatus que foi estendida em cerca de vinte características, incluindo a anatomia dos recémnascidos. Dentre as características contempladas estão: coloração, antenas, dobras dorsais, distinção entre papilas orais e lobópodes, mandíbula, aberturas genital e do ânus, e anatomia interna. Em relação às espécies neotropicais, Sedgwick emendou a descrição e distribuição de $P$. edwardsii. Além disso, são citados apenas como "Peripatus" os primeiros registros no Brasil, coletados em Santarém e da Ilha do Marajó (localidades do Pará). Na introdução desse trabalho também há um relatado sucinto sobre espécimes de onicóforos (coletados por Mr. Edgard J. Evans) nas proximidades do Rio de Janeiro, mas que não foram examinados por Sedgwick.

Após a monografia de Sedgwick as descrições em Onychophora tornaram-se mais detalhadas (com exceções) e auxiliadas por ilustrações. Por exemplo, Pollard (1893) estudou indivíduos de ambos os sexos de Peripatus dominicae Pollard, 1893, descrevendo e ilustrando detalhadamente a morfologia externa e órgãos reprodutivos. Nesse trabalho o autor distinguiu $P$. dominicae de $P$. edwardsii, P. trinidadensis Sedgwick, 1888 e P. torquatus von Kennel, 1883 com base em estruturas internas e na anatomia dos arcos de solas dos lobópodos (ou pernas).

Pocock (1894) apresentou um novo sumário de informações sobre onicóforos. Nele o autor separou as espécies em três gêneros (dois novos), de acordo com a área de distribuição: Peripatus Guilding, 1826 (América), Peripatopsis Pocock, 1894 (África do Sul) e Peripatoides Pocock, 1894 (Austrália). Para identificação desses gêneros, o autor fez uma chave de identificação, baseada no número de pernas e na localização do poro genital desses três gêneros.

Bouvier (1898) descreveu Peripatus tholloni, espécie encontrada no Gabão (África), notando que essa espécie apresenta características intermediárias entre os onicóforos africanos (como número de $\operatorname{arcos}$ de sola) e americanos (poro genital). A partir dessa observação, Bouvier sugere uma proximidade entre espécies americanas e africanas austrais. 
Bouvier (1899a, 1899b) redescreveu 14 espécies de onicóforos americanos, dentre elas Peripatus edwardsii, P. simoni Bouvier, 1899, P. trinidadensis e P. imthurmi Sclater, 1888, e ofereceu uma chave de identificação de onicóforos priorizando a morfologia do tegumento dorsal e a forma dos arcos de sola e papilas crurais. Bouvier reconhece a importância taxonômica das papilas crurais (característica dos machos), mas nem sempre estão evidentes, e interespecificamente podem variar em número e no desenvolvimento. Como o próprio autor considerou, esse trabalho foi um predecessor de uma contribuição maior para Onychophora (as monografias sobre esse filo). Bouvier separou onicóforos neotropicais em "andícolas" e "caraíbas". O grupo "andícola" foi caracterizado pela presença de quatro a cinco papilas nos pés, e a papila urinária inserida no terceiro arco de sola. Por sua vez, o grupo "caraíbas" apresenta três papilas nos pés e a papila urinária entre a terceira e a quarta solas. Esse trabalho foi a primeira tentativa de caracterizar os onicóforos neotropicais.

Bouvier (1900) também descreveu Peripatus ohausi Bouvier, 1900, até então a espécie mais meridional do grupo "caraíbas". A espécie foi descrita com base em duas fêmeas coletadas no entorno da cidade de Petrópolis, no estado do Rio de Janeiro. Essa espécie foi descrita com poucos detalhes, mas enfatizando a forma quadrangular das papilas e dobras dorsais, e o número de lobópodes.

Evans (1901) cunhou o nome Peripatidae, até então a única família de Onychophora, subdividida em quatro subfamílias: Peripatinae (Eoperipatus, Mesoperipatus e Peripatus) e Peripatoidinae (Peripatoides e Opisthopatus), Peripatopsinae (Peripatopsis) e Paraperipatinae (Paraperipatus).

A monografia de Bouvier (1905) ainda é o maior trabalho taxonômico desenvolvido até hoje em Peripatidae. Foram examinados espécimes das coleções do Museu de História Natural Britânico, Museu Nacional de História Natural da França, além das coleções dos museus da Bélgica, Alemanha e Itália, num total de trinta e quatro espécies analisadas: doze "andícolas", dezoito "caraíbas" (incluindo duas variações), uma africana e três asiáticas. Esse trabalho conta com descrições robustas, cento e quarenta figuras, dezoito pranchas e cinco chaves de identificação que sustentaram suas conclusões sobre a delimitação de Peripatidae com comentários sobre Peripatopsidae (formalmente criada em 1907).

A primeira monografia de Bouvier (1905) é considerada um marco na taxonomia e sistemática de Onychophora, pois compilou e organizou as informações do grupo em um único trabalho. Esse trabalho, que tem a maior parte dedicada à Peripatidae, supera a segunda monografia (Bouvier 1907, dedicada a Peripatopsidade) devido à vasta quantidade de informação apresentada sobre os onicóforos. Sua contribuição foi extremamente robusta, de maneira que as classificações contidas nesse trabalho mudaram pouco, além de fornecer suporte para estudos atuais em Peripatidae. Naquela 
época já eram conhecidas as espécies $P$. biolleyi, $P$. brasiliensis, $P$. edwardsii, $P$. evansi, $P$. imthurni, P. nicaraguensis, $P$. nicaraguensis var. isthmicola, $P$. trinidadensis e $P$. simoni.

Bouvier (1906) registrou a primeira ocorrência de P. edwardsii para o Brasil. O exemplar, fêmea, foi capturado no Espírito Santo, Porto Cachoeiro, rio Doce. Na mesma época, a espécie já apresentava registros para Guiana e Venezuela. Esse trabalho estendeu a distribuição de $P$. edwardsii e despertou a curiosidade dos zoólogos, como Carvalho (1911), Marcus (1937) e Marcus \& Marcus (1955), sobre as espécies que ocorrem no Brasil, que na época apresentava quatro registros: $P$. edwardsii, P. brasiliensis Bouvier, 1899, P. geayi Bouvier, 1899 e P. ohausi.

Brues (1911) suspeitou da ocorrência de onicóforos em Granada (ilhas Granadinas) e por intermédio do Dr. Barbour, Brues conseguiu acompanhar a expedição do Dr. Allen à Granada entre agosto e setembro de 1910. Durante essa expedição, Brues encontrou o primeiro registro desses animais nessa ilha, reconhecida como uma espécie nova e que apresentava grandes semelhanças com P. trinidadensis. Essa espécie foi descrita como P. barbouri Brues, 1911.

Clark (1913a) propôs a revisão dos grupos descritos por Bouvier (1905, 1907). Nesse trabalho, Peripatidae passou a apresentar duas subfamílias (Peripatinae e Eoperipatinae), três gêneros (Eoperipatus, Mesoperipatus, Oroperiatus e Peripatus) e quatro subgêneros (todos em Peripatus). Os subgêneros foram nomeados: 1) $P$. (Epiperipatus), espécie-tipo $P$. (Epiperipatus) edwardsii; 2) $P$. (Macroperipatus), espécie-tipo P. (Macroperipatus) torquatus, 3) P. (Plicatiperipatus), espécie-tipo P. (Plicatiperipatus) jamaicensis, e 4) Peripatus (Peripatus), espécie-tipo P. (Peripatus) juliformis. Esse trabalho também é um marco na história da taxonomia de Onychophora mundial, pois reorganizou a classificação das espécies. A criação dos subgêneros mostrou a intenção de organizar a sistemática de Onychophora de forma mais clara. Nessa época Epiperipatus apresentava dez espécies que passaram a ser citadas da seguinte forma: Peripatus (Epiperipatus) biolleyi, $P$. (Epiperipatus) barbouri, P. (Epiperipatus) brasiliensis, P. (Epiperipatus) edwardsii, $P$. (Epiperipatus) evansi, P. (Epiperipatus) imthurni, P. (Epiperipatus) nicaraguensis, P. (Epiperipatus) nicaraguensis var. isthmicola, P. (Epiperipatus) trinidadensis e P. (Epiperipatus) simoni.

No mesmo ano, Mr. W. E Broadway, da Estação Botânica de Tobago, coletou e enviou um exemplar de onicóforo para Austin Hobart Clark (1913b). O exemplar foi reconhecido como uma espécie nova, denominada como P. (Peripatus) broadwayi Clark, 1913, que possuía apenas pequenas diferenças de coloração em comparação com P. (Peripatus) trinidadensis e P. (Peripatus) barbouri.

Cockerell (1913) estudando a fauna da Guatemala reconheceu uma variedade, que foi designada como P. (Epiperipatus) biolleyi var. betheli coletada por Mr. Bethel. Cockerell levou em consideração a distância entre a localidade tipo de P. (Epiperipatus) biolleyi e o novo registro, bem como aspectos 
morfológicos (das papilas dorsais, mandíbulas e papilas crurais) para diagnosticar a espécie nova considerada muito próxima de $P$. (Epiperipatus) biolleyi.

A expedição de Bryant Walker, da universidade de Michigan, visitou Serra Nevada na Colômbia. Durante essa expedição foram coletados espécimes de onicóforos em Santa Marta (Brues 1914). Brues reconheceu três espécies, $P$. (Epiperipatus) edwardsii, P. (Epiperipatus) imthurni e uma nova espécie P. (Epiperipatus) vespuccii Brues, 1914. A espécie foi descrita, mas o autor não conseguiu correlacioná-la claramente com as espécies conhecidas naquela época. Nas palavras de Brues, "It appears impossible, therefore, to associate the present form closely with any described species, although it undoubtedly falls near edwardsii while showing a striking similarity to brasiliensis" (Brues 1914: 378).

Em 1925, o mesmo autor recebeu exemplares de onicóforos oriundos do Panamá. Oito exemplares foram examinados, os quais se assemelhavam à $P$. (Epiperipatus) brasiliensis. Porém suas dobras não pareciam tão longas quanto naquela espécie. Além disso, os exemplares apresentam papilas acessórias que os aproximam de P. (Epiperipatus) imthurni. Desta forma, Brues (1925) reconheceu os exemplares como pertencentes a uma variação de brasiliensis, a qual foi descrita como P. (Epiperipatus) brasiliensis var. vagans.

Marcus (1937) descreveu uma espécie nova, encontrada em Cana Brava e Nova Roma, ente Goiás e Minas Gerais, denominada Peripatus (Epiperipatus) evelinae, sem designar o holótipo. A espécie foi descrita com base na morfologia externa de duas fêmeas, coletadas em 1932. O autor classificou a espécie dentro de Epiperipatus por causa da regularidade das papilas principais, as quais nos síntipos são regulares em tamanho, e justificou a designação da nova espécie com base em características presentes nos lobópodes e no arranjo das papilas dorsais.

Em 1955, Marcus \& Marcus descreveram uma espécie nova para Minas Gerais, coletada no município de Ouro Preto, Tripuí, denominada Peripatus acacioi. Segundo os autores, os dois exemplares capturados apresentavam a morfologia das papilas parecidas com as de Peripatus (Macroperipatus) ohausi. Entretanto, a cor e o número de dentes acessórios diferem de P. ohausi, condição suficiente para que os autores designassem os exemplares de Tripuí como uma espécie nova para o Brasil. Esse trabalho é considerado um novo marco na pesquisa sobre onicóforos no Brasil, pois descreveu a espécie que foi alvo de experimentos sobre fisiologia animal (até hoje desenvolvidos) e foi utilizada como espécie bandeira para transformação de sua localidade tipo em área de preservação ambiental, a primeira destinada à proteção de um invertebrado no Brasil.

Scorza (1953) descreveu Peripatus (Epiperipatus) torrealbai, baseado em quatro exemplares de onicóforos coletados nos arredores do Lago Valencia (localizado entre Carabobo e Aragua, na 
Venezuela). Apesar de diagnosticada como pertencente à Epiperipatus, estranhamente o autor correlacionou a espécie nova com $P$. juliformis, que difere de E. torrealbai por causa da disposição das papilas urinárias e papilas principais.

Ross H. Arnett recebeu o privilégio de estudar uma grande quantidade de onicóforos da Jamaica, que foram coletados por C. Bernard Lewis (Diretor do Instituto da Jamaica e curador do museu de ciência). Arnett (1961) foi capaz de reconhecer uma espécie nova dentre os exemplares examinados, mesmo com a maioria do material gravemente destruída pela ação do líquido fixador (álcool). A espécie nova, Peripatus (Epiperipatus) lewisi Arnett, 1961, se aproxima de Peripatus (Epiperipatus) edwardsii (do Panamá), mas difere desta por causa do tamanho e disposição das papilas urinárias.

Froehlich (1968) reexaminou, por sugestão do Dr. Ernest Marcus, os espécimes de Onychophora da coleção do Departamento de Zoologia da Faculdade de Filosofia da Universidade de São Paulo. Dessa coleção ele identificou quatro espécies, sendo uma delas nova. Dentre os resultados estão: 1) a nova combinação Peripatus (Peripatus) evelinae com designação do lectótipo, e 2) a descrição de Peripatus (Epiperipatus) tucupi Froelich, 1968, com localidade-tipo "Pará". A espécie foi descrita com base em duas fêmeas, que são as únicas representantes dessa espécie.

Peck (1975) revisou a distribuição dos onicóforos e descreveu uma espécie nova, cavernícola da Jamaica, nomeada Speleoperipatus spelaeus. Peck apresentou uma chave de identificação dos onicóforos, resultado da compilação dos trabalhos de Bouvier (1905, 1907) e Clark (1913), e uma atualização da lista de espécies do Novo Mundo. Nessa época, Epiperipatus contava com dezessete espécies, mas Peck não citou E. torrealbai e nem E. betheli no checklist das espécies de Epiperipatus.

Buscando aumentar o arcabouço taxonômico de Peripatidae, Read (1988a) estudou a morfologia dos onicóforos através da Microscopia Eletrônica de Varredura (MEV). Para o autor, os caracteres taxonômicos atuais dos gêneros e espécies de Peripatidae eram subjetivos, como, por exemplo, a forma e o arranjo das papilas dorsais em Macroperipatus. A partir das imagens de MEV, Read encontrou padrões com valor taxonômico no tegumento de onicóforos. Os padrões foram encontrados nas escamas das papilas dorsais, potencialmente capazes de resolver as inconsistências dos gêneros de Peripatidae, segundo o autor. Até hoje, os trabalhos de Read (1988a, 1988b), assim como Ruhberg (1985), influenciam os estudos morfológicos em Onychophora. Por exemplo, MoreraBrenes \& Monge-Nájera (1990) descreveram E. hilkae encontrada nos bosques tropical seco da Costa Rica, já utilizando imagens de MEV. Para os autores, as imagens geradas em MEV são melhores que o estudo em microscópio optico para o estudo da anatomia externa dos onicóforos. 
Oliveira et al. (2010) imprimiram um teor mais refinado à taxonomia de Peripatidae ao incluir dados de MEV à descrição de espécies e revisar duas espécies que ocorrem no Brasil. Nesse trabalho foram feitas duas novas combinações: Epiperipatus acacioi (Marcus \& Marcus 1955) e Epiperipatus machadoi (Oliveira \& Wieloch 2005). Ambas as espécies pertenciam à Macroperipatus e os autores notaram que características das papilas dorsais e papilas crurais não remetiam ao gênero antigo.

Brito et al. (2010) descreveram Epiperipatus cratensis Brito et al. 2010. A maioria das espécies Neotropicais de Onychophora é encontrada em florestas úmidas. Entretanto, E. cratensis é excessão por ser encontrada em ambiente típico de cerradão (Chapada do Araripe). Morfologicamente, $E$. cratensis se assemelha à E. brasiliensis e E. tucupi, pois apresenta dobras completas (longas dobras dorsais que se estendem até o ventre do animal), mas difere de ambas as espécies por causa do número de pernas, número de escamas na peça apical da papila principal e na coloração dorsal do corpo. Aparentemente, a definição de E. cratensis é ambígua, pois é baseada em variações quantitativas de poucos espécimes examinados, e esse talvez seja o motivo pelo qual Oliveira et al. (2012a) sugeriram a revisão dessa espécie.

Oliveira e colaboradores se debruçaram sobre os estudos taxonômicos em Peripatidae, nos mais importantes trabalhos dos últimos cinco anos (2011, 2012a, 2012b, 2013, 2015). Dentro desse período foram descritas seis espécies (três de Epiperipatus: E. adenocryptus Oliveira et al., 2011, E. diadenoproctus Oliveira et al., 2011 e E. paurognostus Oliveira et al., 2011. Os autores realizaram estudos filogenéticos dentro da família, mas abstiveram-se das revisões sistemáticas e utilizaram os resultados para a sustenção das novas espécies apresentadas.

Murienne et al. (2014) apresentam uma discussão sobre padrões biogeográficos em Onychophora, e sobre a evolução de cada família do filo. Pode-se afirmar que essa é a mais abrangente amostragem de Peripatidae publicada até o momento, com espécies das Américas, África e Ásia. De acordo com esse trabalho, Onychophora estava distribuído pelo supercontinente Pangea, e seus grupos diversificaram anteriormente à quebra desse continente. Além disso, os resultados sugerem que os eventos de cladogênese em Peripatidae ocorreram anteriormente à separação entre África e América, refutando a possibilidade de dispersão transoceânica das espécies dessa família.

O último trabalho em Epiperipatus tratou da nova combinação Epiperipatus ohausi proposta por Chagas-Junior \& Costa (2014), que revisaram a morfologia externa dessa espécie. Com isso, Epiperipatus passou a ter vinte e seis espécies, e é o gênero mais diverso e amplamente distribuído de Peripatidae. Nos últimos seis anos foi o gênero que mais recebeu espécies (sete) em Peripatidae e, no entanto, é morfologicamente mal delimitado (Sampaio-Costa et al. 2009). No presente estudo Epiperipatus foi incorporado em um abrangente estudo filogenético de Peripatidae, auxiliado por 
dados moleculares e morfológicos de Onychophora. Epiperipatus se mostrou parafilético, e por isso seus problemas taxonômicos foram trabalhados conforme apresentado a seguir.

\section{III - DELIMITAÇÃO DE EPIPERIPATUS}

A delimitação de Epiperipatus é imprecisa desde a primeira definição, oferecida por Bouvier (1905), onde esse grupo ainda não apresentava status de subgênero, as espécies eram descritas dentro de Peripatus e as primeiras espécies de Epiperipatus estavam reunidas na "seção de $P$. Edwardsi" dos onicóforos “caraíbas". Essa definição é mantida até o presente momento, onde há um elevado número de características compartilhadas, principalmente com Peripatus, e não existe uma característica exclusiva. Morfologicamente, Epiperipatus e Peripatus são muito semelhantes, e a separação dos gêneros é feita com base em variações do número de glândulas crurais presentes nas pernas, e no número de escamas presentes nas papilas principais. Entretanto, esses caracteres são difíceis de serem interpretados, pois não é claro o limite de variação quantitativa desses caracteres, resultando em identificações ambíguas. Desta forma, o status de Epiperipatus torna-se duvidoso dentro da taxonomia de Peripatidae.

A delimitação desse gênero contempla caraterísticas de interpretação ambígua, com equívocos de interpretação morfológica, como, por exemplo, a distância entre papilas dorsais, e o número de pernas com papilas crurais, que claramente não delimitam esse gênero. As revisões oferecidas por Clark (1913) e Peck (1975) apenas intensificaram o problema taxonômico dos gêneros neotropicais de Peripatidae. Aparentemente essas revisões foram realizadas sem uma revisão detalhada dos caracteres delimitadores dos gêneros de Peripatidae. Assim, quatro gêneros caribenhos difíceis de serem reconhecidos (Epiperipatus, Peripatus, Macroperipatus e Speleoperipatus) são mantidos.

Oliveira et al. (2010, 2011, 2012a, 2012b, 2013, 2015) abordaram a taxonomia de Peripatidae com uma perspectiva filogenética, mas pouco contribuíram para revisão dos gêneros pré-existentes aos seus trabalhos. A pequena quantidade de gêneros inclusos nas análises filogenéticas pode ter contribuído para a superestimação dos resultados, como, por exemplo, a informação filogenética das características morfológicas exploradas por esses autores, como estruturas sensoriais das antenas e modificações do tegumento ventral. Esses autores advogam que a diversidade de caracteres morfológicos não explorados, porém não há estudos filogenéticos que refutem essa hipótese.

Embora o volume de estudos filogenéticos em Peripatidae tenha aumentado nos últimos cinco anos, parece que os esforços não foram suficientes para conhecer a real distribuição da diversidade de espécies dessa família. Nesse contexto, Epiperipatus permanece como o maior gênero de 
Peripatidae, imprecisamente delimitado e funcionando como um depósito de espécies mal conhecidas.

Apesar de estar incluso em diversos estudos filogenéticos de Metazoa, as relações filogéneticas internas de Onychophora ainda são pouco exploradas e estudadas. Talvez em função do número restrito de famílias e espécies, e a dificuldade de acesso de material, ainda sejam poucos os estudos cladísticos em Onychophora. Os grandes estudos filogenéticos realizados nesse filo ainda são voltados para Peripatopsidae (Ruhberg 1985, Reid 1996), talvez por causa da facilidade de acesso a informação, que é maior nessa família. A participação de Peripatidae em estudos filogenéticos é apenas coadjuvante, funcionando como grupo-externo, embora seja importante para estudos biogeográficos (Murienne et al. 2014).

Read (1988a) propôs novas características taxonômicas para os gêneros de Peripatidae, mas não as testou filogeneticamente. Murienne et al. (2014) mostraram um panorama simples da relação filogenética entre sete dos doze gêneros de Peripatidae, incluindo Epiperipatus. Porém o cladograma apresentado sugere o parafiletismo de Epiperipatus, Macroperipatus e Peripatus. Por exemplo, os três representantes de Epiperipatus, dentre eles E. edwardsii, não formam um grupo monofilético.

Oliveira et al. $(2011,2012,2015)$ incluíram Epiperipatus em seus estudos filogenéticos, mas resultados morfológicos produzidos por esses autores são difíceis de serem replicados. Por exemplo, para observação em MEV das depressões no tegumento ventral chamada “órgãos ventrais" (Oliveira et al. 2012, 2015), é necessário que o tegumento tenha contraído pouco durante a fixação. Esses estudos são caracterizados por grandes números amostrais superiores a quarenta exemplares da mesma espécie, obtidos através de culturas em laboratório, para contemplação das variações morfológicas das espécies. A estratégia pode ser interessante para um estudo detalhado da morfologia das espécies de Peripatidae, porém é inviável para estudos evolutivos envolvendo gêneros diversos e amplamente distribuídos, como Epiperipatus, em função da demanda de espaço e tempo para criação e cultivo, e imprecisão da localidade-tipo de várias espécies desse gênero. Esses autores também ampliaram a diversidade de Epiperipatus com a apresentação de três espécies endêmicas (Oliveira $e t$ al. 2011). E. adenocryptus, E. diadenoproctus e E. paurognostus são suportadas por resultados de inferências filogenéticas baseadas em dados moleculares. Entretanto, incluir mais marcadores numa análise de evidência total poderia trazer mais informação e dar mais suporte aos resultados desses autores (Dikow 2009, Kluge 1989, Kluge 2004).

O conhecimento acumulado nos últimos cinco anos sobre Peripatidae ainda é insuficiente para esclarecer as relações filogenéticas internas dessa família. Nenhuma das hipóteses filogenéticas e abordagens taxonômicas oferecidas recentemente (Oliveira et al. 2011, 2012, 2015) foram testadas. 
Nota-se também o reconhecimento de novos táxons em Peripatidae, em detrimento da revisão taxonônica dos gêneros e espécies preexistentes. Epiperipatus é um dos mais interessantes gêneros de Peripatidae, devido a sua peculiar distribuição geográfica (que abrange as Antilhas e as Américas Central e do Sul) e à diversidade de espécies. Recentemente, o monofiletismo de Epiperipatus foi contestado (Oliveira et al. 2012 e 2015). Porém, desde sua criação nunca passou por uma revisão sistemática, e que cada vez mais se torna necessária.

\section{IV - SÍNTESE DOS OBJETIVOS DA TESE}

O objetivo desta tese é a revisão taxonômica de Epiperipatus com auxílio do resultado de análises filogenéticas que contemplaram dados morfológicos e moleculares desse gênero. As seguintes questões norteiam a realização desta tese:

1 - Quantos gêneros da família Peripatidae existem no continente americano?

Na região neotropical há nove gêneros de Peripatidae, e a delimitação de todos eles sempre foi insatisfatória, devido a: 1) baixa informação morfológica (é um grupo conservativo), 2) má amostragem das espécies, 3) descrições baseadas em caracteres ambíguos; e 4) poucos estudos dedicados a revisão sistemática dentre dessa família, ou que contemplam um restrito número de terminais. Com o objetivo de contribuir para essa resposta, Epiperipatus (o gênero americano mais diverso de Onychophora) foi submetido a uma análise filogenética, que contemplou dados morfológicos e moleculares concatenados. Esse estudo constiuiu o maior banco de dados de Peripatidae já levantado até o momento: 155 espécimes examinados, oriundos das Américas Central e Sul, África e Malásia. Inicialmente o gênero se mostrou parafilético, mas para evitar essa condição dois gêneros foram considerados sinonimizados e cinco espécies foram transferidas para Epiperipatus. Desta forma, reduziu-se para sete os gêneros neotropicais. Além disso, também foram incluídas cinco novas espécies.

\section{2 - Quem é Epiperipatus e como ele é delimitado?}

Este estudo sugere que Epiperipatus é o mais diverso e com a maior distribuição dentre os gêneros de Peripatidae. A partir deste estudo são contabilizadas trinta e cinco espécies para esse gênero. Sua distribuição cobre a Costa Rica (também ocorrendo nas Antilhas), descendo até a América do sul, onde se distribui pela Colômbia, Venezuela, Guiana, Suriname, Guiana Francesa e predominando no Brasil. 
A taxonomia dos onicóforos americanos resume-se à diferença de estados das estruturas: papilas dorsais, mandíbulas, pernas e o ânus dos machos. Para elucidar a delimitação de Epiperipatus, a morfologia desse gênero foi revisada através do mapeamento das características morfológicas, nas topologias apresentadas neste estudo. Com auxílio dos dados moleculares foi possível reunir um conjunto de características morfológicas para definir Epiperipatus. Nossos resultados sugerem que esse gênero apresenta um grau elevado de variação de morfológica, conforme é notado a seguir.

As papilas principais apresentam peça apical simétrica ou assimétrica, e sua forma varia entre cônica, cilíndrica e achatada (raramente). $\mathrm{Na}$ base das papilas principais, o número de escamas enfileiradas, verticalmente, varia entre quarto e dezoito escamas. Geralmente, as pernas apresentam quatro arcos de sola, e raramente um quinto arco pode estar presente. Quando presente, este arco sempre é reduzido em comparação aos arcos de sola anteriores. As papilas crurais sempre ocorrem entre o terceiro e o quarto arco de solas, do quarto e quinto pares de pernas. Nesses mesmos pares de pernas, são contados, nos pés, duas papilas pró-laterais e uma retrolateral, embora exceções ocorram.

De acordo com os resultados, a delimitação morfológica baseia-se em simplesiomorfias. Entretanto, Epiperipatus é suportado por sinapomofias não ambíguas distribuídas entre quatro marcadores moleculares (COI, 12S, 16S e 18S) selecionados para este estudo.

\section{V - ORGANIZAÇÃO DA TESE}

Este estudo foi dividido em dois capítulos independentes, para facilitar a discussão dos resultados e leitura. Os capítulos correspondem a artigos que em breve serão enviados para revistas científicas. Além deste capítulo, a tese está divida da seguinte forma:

O Capítulo 2, "Phylogenetic inferences of Epiperipatus Clark, 1913 (Onychophora: Peripatidae) based on molecular and morphological data”, trata, através de estudos filogenéticos, do posicionamento e delimitação morfológica adequados de Epiperipatus, com base em análises de evidência total.

O Capítulo 3, "On taxonomic status of twenty-one species of Epiperipatus Clark 1913, with descriptions of five new species", é a consequência dos resultados apresentados no Capítulo 2. Nele são realizados, formalmente, os atos nomenclaturais necessários para o reconhecimento de Epiperipatus, as emendas na descrição de Epiperipatus e suas espécies, a descrição de cinco espécies novas, e a atualização da lista de espécies desse gênero.

O Capítulo 4. Mostra um panorama final deste estudo, com as principais conclusões apresentadas nos capítulos anteriores. 
Aguinaldo, A. M. A., Turbeville, J. M., Linford, L. S., Rivera, M. C., Garey, J. R., Raff, R. A. \& Lake, J. A. 1997. Evidence for a clade of nematodes, arthropods and other moulting animals. Nature, 387: 489-493.

Arnett, R. H. 1961. The Onychophora of Jamaica. Entomological News, 72: 213-220.

Blanchard, E. 1847. Recherches sur l'organisation des vers. Annales des Sciences Naturelles, Zoologie, 3(8): 119-149.

Bouvier, E. L. 1898. Note préliminaire sur la distribution géographique et l'évolution des Péripates. Compte Rendu Hebdomadaire des Séances L'Academie des Sciences (Paris), 126 (19): 13581361.

Bouvier, E. L. 1899a. Nouvelles observations sur les Péripates américains. Comptes Rendus Hebdomadaires des Seances de l'Academie des Sciences, 129: 1029-1031.

Bouvier, E. L. 1899b. Contributions a l'histoire des Péripates américains. Annales de la Sociéte Entomologique de France, 68: 385-450.

Bouvier, E. L. 1900. Nouveau Péripate des environs de Rio-de-Janeiro. Bulletin de la Société Entomologique de France, 3:66-68.

Bouvier, E. L. 1905. Monographie des Onychophores. Annales des Sciences Naturelles, Zoologie, [9e Série], 2: 1-383.

Bouvier, E. L. 1906. Observation biologique. Le Peripatus Edwardsi au Brésil. Bulletin de la Société Entomologique de France, 19: 268.

Bouvier, E. L. 1907. Monographie des Onychophores. Annales des Sciences Naturelles, Zoologie [9e Série], 5(1-6): 61-318.

Brito, S. V., Pereira, J. C., Ferreira, F. S., Vasconcellos, A. \& Almeida, W. O. 2010. Epiperipatus cratensis sp. nov. (Onychophora: Peripatidae) from northeastern Brazil. Neotropical Biology and Conservation, 5: 47-52. doi: 10.4013/nbc.2010.51.07.

Brusca, R. C. \& Brusca, G. J. 2003. Invertebrates (2nd Ed.). Sinauer Associates, Massachusetts

Brues, C. T. 1911. A new species of Peripatus from Grenada, with observations on other species of the genus. Bulletin of the Museum of Comparative Zoology, 54: 303-318.

Brues, C. T. 1914. A new Peripatus from Colombia. Bulletin of the Museum of Comparative Zoology, 
58: $375-382$.

Brues, C. T. 1925. Notes on neotropical Onychophora. Psyche, 32: 159-165.

Carvalho, A. L. 1941. Nota prévia sôbre uma nova espécie de "Peripatus" do Brasil Central. Revista brasileira de Biologia, 1 (4): 447-448.

Chagas-Junior, A. \& Costa, C. S. 2014. Macroperipatus ohausi: redescription and taxonomic notes on its status (Onychophora : Peripatidae). Revista de Biología Tropical, 62: 977-985.

Clark, A. H. 1913a. Revision of the American species of Peripatus. Proceedings of the Biological Society of Washington, 26: 15-19.

Clark, A. H. 1913b. Piccole note su degli Onychophora. Zoologischer Anzeiger, 42: 253-255.

Cockerell, T. D. A. 1913. A Peripatus from Guatemala. Proceedings of the Biological Society of Washington, 26: 87-88.

Dikow, T. 2009. A phylogenetic hypothesis for Asilidae based on a total evidence analysis of morphological and DNA sequence data (Insecta: Diptera: Brachycera: Asiloidea). Organisms, Diversity \& Evolution, 9: 165-188.

Ernst, A. 1881. Some remarks on Peripatus edwardsii, Blanch. Nature, 23(593): 446-448.

Evans, R. 1901. On two new species of Onychophora from the Siamese Malay States. Quarterly Journal of Microscopical Science, 44: 473-538.

Froelich, C. G. 1968. On some Brazilian onychophores. Beiträge zur neotropischen Fauna, 5(3): 160171.

Guilding, L. 1826. Mollusca carribbaeana. Zoological Journal (London), 2(14): 157-160.

Kluge, A. G. 1989. A Concern for Evidence and a Phylogenetic Hypothesis of Relationships Among Epicrates (Boidae, Serpentes). Systematic Zoology, 38(1): 7-25.

Kluge, A. G. 2004. On total evidence: for the record. Cladistics, 20: 205-207.

Marcus, E. 1937. Um Onychophoro novo, Peripatus (Epiperipatus) evelinae, spec. nov. de Goyaz. Revista do Museu Paulista, 21: 903-910.

Marcus, E. \& Marcus, E. 1955. A new Peripatus from Minas Gerais, Brazil. Anais da Academia Brasileira de Ciências, 27:189-193.

Monge-Nájera, J. 1995. Phylogeny, biogeography and reproductive trends in the Onychophora. Zoological Journal of the Linnean Society, 114: 21-60. 
Monge-Nájera, J. 1996. Jurassic-Pliocene biogeography: testing a model with velvet worm (Onychophora) vicariance. Revista de Biología Tropical, 44(1): 159-175.

Morera-Brenes, B. \& Monge-Nájera, J. 1990 Epiperipatus hilkae, n. sp. from Costa Rica (Onychophora: Peripatidae). Revista de Biología Tropical, 38: 449-455.

Moseley, H. N. 1879. Notes on the species of Peripatus, and especially on those of Cayenne and the West Indies. Annals and Magazine of Natural History [5e Série], 3 (16): 263-267.

Murienne, J., Daniels, S. R, Buckley, T. R., Mayer, G. \& Giribet, G. 2014. A living fossil tale of Pangaean biogeography. Proceedings of the Royal Society B: Biological Sciences, 281: 20132648. http://dx.doi.org/10.1098/rspb.2013.2648.

Oliveira, I. S., Franke, F. A., Hering, L., Schaffer, S. \& Rowell, D. M. 2012b. Unexplored Character Diversity in Onychophora (Velvet Worms): A Comparative Study of Three Peripatid Species. PLoS ONE, 7(12): e51220.

Oliveira, I. S., Lacorte, G. A., Fonseca, C. G., Wieloch, A. H. \& Mayer, G. 2011. Cryptic Speciation in Brazilian Epiperipatus (Onychophora: Peripatidae) Reveals an Underestimated Diversity among the Peripatid Velvet Worms. PLoS ONE, 6: 1-13.

Oliveira, I. S., Lacorte, G. A., Weck-Heimann, A., Cordeiro, L. M., Wieloch, A. H. \& Mayer, G. 2015. A new and critically endangered species and genus of Onychophora (Peripatidae) from the Brazilian savannah - a vulnerable biodiversity hotspot. Systematics and Biodiversity, 13: 211233.

Oliveira, I. S., Read, V. M. St. J. \& Mayer, G. 2012a. A world checklist of Onychophora (velvet worms), with notes on nomenclature and status of names. ZooKeys, 211: 1-70.

Oliveira, I. S, Tait, N. N., Strübing, I. \& Mayer, G. 2013. The role of ventral and preventral organs as attachment sites for segmental limb muscles in Onychophora. Frontiers in Zoology, 10:73.

Oliveira, I. S., Wieloch, A. H. \& Mayer, G. 2010. Revised taxonomy and redescription of two species of the Peripatidae (Onychophora) from Brazil: a step towards consistent terminology of morphological characters. Zootaxa, 2493:16-34.

Peck, S. B. 1975. A review of the New World Onychophora with the description of a new cavernicolous genus and species from Jamaica. Psyche (Cambridge), 82: 341-358.

Pocock, R. I. 1894. Contributions to our knowledge of the arthropod fauna of the West Indies - Part III. Diplopoda and Malacopoda, with a supplement on the Arachnida of the class Pedipalpi. 
Journal of the Linnean Society - Zoology, 24: 473-544.

Pollard, E. C. 1893. Notes on the Peripatus of Dominica. Quarterly Journal of Microscopical Science, 35: 285-293.

Read, V. M. S. J. 1988a. The application of scanning electron microscopy to the systematics of the neotropical Peripatidae (Onychophora). Zoological Journal of the Linnean Society, 93: 187223.

Read, V. M. S. J. 1988b. The Onychophora of Trinidad, Tobago and the Lesser Antilles. Zoological Journal of the Linnean Society, 93(3): 225-257.

Reid, A. 1996. Review of the Peripatopsidae (Onychophora) in Australia, with comments on peripatopsid relationships. Invertebrate Taxonomy, 10(4): 663-936.

Ruhberg, H. 1985. Die Peripatopsidae (Onychophora) Systematik, Ökologie, Chorologie und phylogenetische Aspekte. Zoologica (Stuttgart), 137: 1-184.

Sampaio-Costa, C., Chagas-Junior, A. \& Baptista, R. L. C. 2009. Taxonomy and distribution of Brazilian Onychophora. Revista Brasileira de Zoologia, 26(3): 553-561.

Sedgwick, A. 1888. A monograph on the species and distribution of the genus Peripatus (Guilding). Quarterly Journal of Microscopical Science, 28: 431-493.

Scorza, J.V. 1953. Contribución al estudio de los Peripatus Caribes (Epiperipatus) de Venezuela, con adición de una nueva especie. Revista de sanidad y asistencia social, 18: 783-788. 


\title{
Chapter 2. Phylogenetic studies of Epiperipatus Clark, 1913
}

\section{Phylogenetic inferences of Epiperipatus Clark, 1913 (Onychophora: Peripatidae) based on molecular and morphological data}

\author{
Costa, C. S. ${ }^{1}{ }^{*}$, GIRIBET, G. ${ }^{2}$ AND PINTO-DA-Rocha, R. ${ }^{1}$ \\ ${ }^{1}$ Departamento de Zoologia, Instituto de Biociências, Universidade de São Paulo. Rua do Matão, Travessa 14, n 321, \\ Cidade Universitária, São Paulo, SP, Brasil. CEP 05508-090. E-mail: ricrocha@usp.br \\ ${ }^{2}$ Museum of Comparative Zoology, Department of Organismic and Evolutionary Biology, Harvard University, 26 \\ Oxford Street, Cambridge, MA 02138, USA. E-mail: ggiribet@g.harvard.edu \\ *E-mail: csampaioc@gmail.com
}

\begin{abstract}
Many authors consider Onychophora as key groups for phylogenetic reconstruction of metazoan evolution. Nowadays their living species are divided in two families: Peripatopsidae and Peripatidae. However, the interrelationships among members of these two families remain poorly known. These families present unresolved taxonomic conditions, but Peripatidae has the most problems. The taxonomic problems seem critical among the Neotropical species, because their morphological characterizations vary widely and are insufficient for accurate identification. For this reason we decided to gather molecular and morphologic datasets of onychophorans from Central and South America, Africa and Malaysia for phylogenetic studies. Four analyses were implemented: two parsimony analyses each exclusive of morphological or molecular data; one parsimony analysis encompassing molecular and morphological data (total evidence); and one maximum likelihood analysis of molecular data. The exclusive morphological analysis was inconclusive, while the other analyses show that species diversity is concentrated in two Neotropical genera. Epiperipatus resulted as a non-monophyletic group, as it includes species described in other genera. To avoid the paraphyly condition of Epiperipatus, Cerradopatus and Principapillatus genera should be synonymized with Epiperipatus. Therefore, Epiperipatus presents stable relationships across the five clades of Neotropical onychophorans, as observed in parsimony versus maximum likelihood analyses, except for the clade where Epiperipatus edwardsii (Blanchard, 1847) nested. We suggest the new combination, E. bouvieri, E. hitoyensis, E. solorzanoi and E. sucuriuensis.
\end{abstract}

Keywords: Phylogenetic systematics, molecular systematics, new world, Epiperipatus, synonyms, new species. 


\section{INTRODUCTION}

Onychophora is an example of a poorly resolved metazoan phylum. Its relationships to other phyla are stable, providing support for Panarthropoda and Ecdyzosoa (Aguinaldo et al. 1997, Mallatt $\&$ Giribet 2006). Nonetheless, authors reported taxonomic problems within the phylum, and phylogenetic studies in Onychophora are rare (Read 1988a, Oliveira et al. 2012b; Chagas-Junior \& Costa 2014; Murienne et al. 2014). The first Peripatopsidae phylogenetic studies took place in the end of the 20th century (Ruhberg 1985). Twenty-seven years later, the first Peripatidae phylogenetic studies were presented, although they were restricted to distribution, taxonomy and biogeography (Murienne et al. 2014, Oliveira et al. 2012a).

Bouvier (1905) created two onychophoran groups with Neotropical distribution. The "andicoles" were represented only by members of Oroperipatus Cockerell, 1908. The "caraïbes" formed a larger group, comprised by all the other Neotropical Peripatidae, including members of Epiperipatus Clark, 1913. The diversity of Peripatidae is concentrated in Epiperipatus and Peripatus, but the poor quality of the morphological characters resulted in misinterpretation of many species of these genera.

Epiperipatus occurs in the Antilles, Central and South America, but most of the species are found in Brazil. This genus is the most diverse and widespread group within Peripatidae. It comprises about 25 species, most of which has been described in the last five years (Brito et al. 2010, Oliveira et al. 2011). Although Epiperipatus is the most intensively studied genera of Peripatidae (Brito et al. 2010, Oliveira et al. 2010, Oliveira et al. 2011, Chagas-Junior 2014), it is poorly defined in terms of synapomorphies (Sampaio-Costa et al. 2009).

Within Epiperipatus there are poorly described species with misleading delimiting characters and uncertain phylogenetic position (Sampaio-Costa et al 2009, Read 1988a, Oliveira et al. 2011). For example, five morphospecies of Epiperipatus found in Brazil could not be identified due to the high number of homoplastic characters used in species-level identification (Sampaio-Costa et al. 2009). Additionally, it is impossible to distinguish Epiperipatus and Peripatus morphologically due to the large number of ambiguous characters present in both genera, such as the shape of dorsal papillae and variation on the number of legs with crural papilla.

Recently, the monophyly of Epiperipatus was contested by three studies, which found it to be paraphyletic with relation to other Peripatidae genera (Oliveira et al. 2012a, 2012b, 2015). Hence, Principapillatus Oliveira et al., 2012b and Cerradopatus Oliveira et al., 2015 were supported by a molecular phylogeny. 
Even with all the criticism over peripatid groups created by Bouvier (afterwards erected to genera), few works attempted to revise the genera, possibly due to the inaccessibility of specimens. Recent phylogenetic studies did not ultimately test the Epiperipatus monophyly, due to the insufficient sampling of this genus. In this context we investigated the monophyly of Epiperipatus. We performed phylogenetic studies based on a large dataset of 175 specimens of Epiperipatus, for which we obtained morphological and molecular data. The morphological and molecular datasets worked complementarily. However, results obtained with morphology and molecules alone diverged. Combined analyses and analyses based on molecular data only resulted in similar topologies. They supported the monophyly of "andicoles" and "caraibes" groups; and four clades within the latter. Moreover, this dataset revealed a large diversity within Neotropical onychophorans. The morphological dataset, on the other hand, suggested that the diversity is concentrated within a few genera. According to our results and the taxonomy of the current Neotropical genera, Epiperipatus is non-monophyletic. Thus, here we reassess the taxonomic status of this genus to maintain monophyletic taxa.

\section{MATERIAL AND METHODS}

Specimen acquisition. Throughout this study, we examined 175 onychophorans, which included 42 sequences from GenBank. Our biological samples were mainly acquired by field expeditions during the period of June 2012 to August 2015. Onychophorans were collected from multiple localities in Central and South America, mostly in Brazil (Figure S.1). The biogeographical provinces (sensu Morrone 2014) visited included Hispaniola, Mosquito, Puntarenas-Chiriqui, Guajira, Magdalena, Ecuadorian, Roraima, Pará, Madeira, Xingu-Tapajós, Caatinga, Cerrado, Atlantic and Valdivian Forest. We also relied on material deposited in reference collections such as Museu Nacional do Rio de Janeiro (MNRJ); Museu de Zoologia da Universidade de São Paulo (MZUSP); Universidade Federal de Minas Gerais (UFMG); Universidade Federal do Mato Grosso do Sul (Ony); Universidade Federal da Paraíba (UFPB); Universidade Federal do Piauí (CHNUFPI); Universidad Nacional de Colombia (ICN-ONY); Universidad Autonóma de Chiriquí (UNACHI) and Museum of Comparative Zoology (MCZ). Specimens from museums and universities collections were examined and tissue samples were obtained for DNA sequencing whenever possible. Specimens and their respective institutions are listed in Supplementary Information (Table S.1).

Newly collected specimens were generally found in the morning when onychophorans are inactive. In general the specimens were found on rotten logs, among deep grass roots, or by digging approximately $10 \mathrm{~cm}$ below leaf litter. In Brazil and Panama, some specimens were collected around 
buildings and piles on roof tiles (usually more than 100 tiles) protected from the sun's radiation by tree cover. After collected, the specimens were photographed and fixed according to Chagas-Junior and Costa (2010). A partial fragment of the velvet worm was extracted (usually the dorsal integument or legs) and fixed in $100 \%$ ethanol and stored at $-10{ }^{\circ} \mathrm{C}$ for DNA studies. Finally, specimens were putatively identified following the original descriptions of Bouvier (1905) and Read (1988a, 1988b).

Molecular data acquisition. For molecular studies, we selected all 175 specimens. Genomic DNA extractions were obtained using Agencourt ${ }^{\circledR}$ DNAdvance ${ }^{\mathrm{TM}}$ DNA Isolation Kit following the specifications of the manufacturer. We amplified partial fragments of cytochrome $c$ oxidase subunit I (COI hereafter), 12S rRNA, 16S rRNA (mitochondrial) and 18S rRNA (nuclear) by PCR reactions. The general PCR protocol included an initial denaturation for $5 \mathrm{~min}$ at $95{ }^{\circ} \mathrm{C}, 35$ cycles of $30 \mathrm{sec}$ at $95^{\circ} \mathrm{C}, 30 \mathrm{sec}$ at $45-55^{\circ} \mathrm{C}$, and $1-2 \mathrm{~min}$ at $72{ }^{\circ} \mathrm{C}$, and a final extension of $7 \mathrm{~min}$ at $72{ }^{\circ} \mathrm{C}$. The specific annealing temperatures for each region were $45^{\circ} \mathrm{C}$ for COI, $12 \mathrm{~S}$ and $16 \mathrm{~S}$ rRNA, and $55{ }^{\circ} \mathrm{C}$ for $18 \mathrm{~S}$ rRNA. All PCR reactions were performed in a Techne ${ }^{\circledR}$ TC-5000TM thermocycler. Primers for amplification and sequencing are in Table 1 . The results of PCR were verified in a $2 \% \mathrm{w} / \mathrm{v}$ agarose gel, 5 volt/cm, stained with GelRed Nucleic Acid Gel Stain (Biotium).

Table 1. List of primer sequences used for amplification and sequencing.

\begin{tabular}{|c|c|c|c|c|}
\hline Primers used for each gene & & & Purpose & Authors \\
\hline \multicolumn{5}{|l|}{ COI rRNA (636 base pairs) } \\
\hline & LCO1490 & 5'-GGTCAACAAATCATAAAGATATTGG-3' & Amp/Seq & Folmer et al . (1994) \\
\hline & HCOoutout & 5'-GTAAATATATGRTGDGCTC-3' & Amp/Seq & Folmer et al . (1994) \\
\hline \multicolumn{5}{|l|}{ 12S rRNA (388 base pairs) } \\
\hline & $12 \mathrm{SAIN}$ & 5'-AAAAACWAGGATTAGATACCCT-3' & Amp/Seq & Pinto-da-Rocha et al. (2014) \\
\hline & $12 \mathrm{SOP} 2 \mathrm{RN}$ & 5'-CССТTAAAYYTACTTTGTTACGACC-3' & Amp/Seq & Pinto-da-Rocha et al. (2014) \\
\hline \multicolumn{5}{|l|}{ 16S rRNA (390 base pairs) } \\
\hline & 16 SpotFN & 5'-GACTGTGCAAAGGTAGCATAATC-3' & Amp/Seq & Pinto-da-Rocha et al. (2014) \\
\hline & $16 \mathrm{SBR}$ & 5'-CCGGTCTGAACTCAGATCACGT-3' & $\mathrm{Amp} / \mathrm{Seq}$ & Pinto-da-Rocha et al. (2014) \\
\hline \multicolumn{5}{|l|}{ 18S rRNA (1023 base pairs) } \\
\hline & $18 \mathrm{SC}$ & 5'-CGGTAATTCCAGCTCCAATAG -3' & $\mathrm{Amp} / \mathrm{Seq}$ & Apakupakul et al. (1999) \\
\hline & $18 \mathrm{SY}$ & 5'-CAGACAAATCGCTCCACCCCA -3' & Seq & Medlin et al. (1988) \\
\hline & $18 \mathrm{~S} 5 \mathrm{~F}$ & 5'-GCGAAAGCATTTGCCAAGAA-3' & Seq & Giribet et al. (1999) \\
\hline & WORMB & 5'-CTTGTTACGACTTTTACTTCC -3' & Amp/Seq & Littlewood and Olson (2001) \\
\hline
\end{tabular}

Legend: Amp - amplification; Seq - sequencing

PCR products were purified using Agencourt AMPure XP (Beckman Coulter, Inc.). Products were then cycle-sequenced directly in forward and reverse directions using the BigDye ${ }^{\circledR}$ Terminator v3.1 Cycle Sequencing Kit (Applied Biosystems), and sequenced in an ABI 3100 Genetic Analyzer at the Centro de Sequenciamento do Departamento de Química, Instituto de Química, of the Universidade de São Paulo. The quality of each chromatogram was accessed using FinchTV version 1.3.1 (Geospiza Inc.). Contiguous sequences were assembled using the package Consed/Phred Phrap (Ewing \& Green 1998, Ewing et al. 1998, Gordon et al. 1998, Gordon et al. 2001). Edits were performed in BioEdit (version 7.0.0, Hall 1999) and then aligned with MAFFT (version 7 online, Katoh \& Standley 2013). 
Morphological data acquisition. We obtained morphological data for 131 adult specimens (See Table S.2). The data included attributes of the external morphology, specifically from legs (the fourth and fifth pair of legs in particular that possess the crural papillae), jaws (inner and outer blades), integument, and the structures of the dorsal papillae (which provide the majority of the data). We coded the multistate morphological characters as unordered on the matrix. We considered all characters that historically have been used in the taxonomy of the group, especially those used in generic diagnoses, in addition to new characters discovered throughout the study.

We compiled morphological characters under a stereomicroscope and Scanning Electronic Microscopy (SEM). For SEM, all tissues were cleaned and dehydrated using an ethanol series (30\%, $50 \%, 70 \%$ and $80 \%$ ). In the cleaning process, soft parts were washed in a solution of hydrochloride $3 \%$ solution diluted in distilled water. The hard parts (e.g., jaws) were cleaned in a solution of distilled water and Ethylenediaminetetraacetic acid (EDTA) in heated solution in an ultrasonic water bath. Then, we used the critical point Auto Samdri 815 Series A (Tousimis) and Baltec CPD 030. Finally, sputter coating was completed using the machines Cressington 208HR sputter coater; Denton Desk IV gold sputter model and Balzer SCD 50 sputter coater. Generally an average of 5 to $10 \mathrm{~nm}$ of gold/paladium or platinum/palladium was deposited over the tissues. SEM images were taken on Carl Zeiss EVOs 50, JEOL JSM-6390LV and DSM 940 Zeiss microscopes. The Backscatter electron detector function was used when available on the microscope to avoid the charging effects on the tissues.

Ingroup and outgroup selection: We included 18 species of Epiperipatus as ingroup-taxa (Table 2), four of them from the MCZ collection and the others from the Museum of Zoology of the University of São Paulo (MZUSP) and from The Natural History Museum, London (NHM). However, we were only possible to collect both morphological and molecular data from 11 species: (1) Epiperipatus edwardsii (Blanchard, 1847) (type species), (2) E. ohausi (Bouvier, 1900), (3) E. biolleyi (Bouvier, 1902), (4) E. isthmicola (Bouvier, 1902), (5) E. brasiliensis (Bouvier, 1899), (6) E. acacioi (Marcus \& Marcus, 1955), (7) E. machadoi (Oliveira \& Wieloch, 2005), (8) E. cratensis Brito et al., 2010, (9) E. adenocryptus Oliveira et al., 2011, (10) E. diadenoprocutus Oliveira et al., 2011 and (11) E. paurognostus Oliveira et al., 2011. The other seven species were only examined morphologically, since they were the type-material or specimens preserved in ethanol for more than fifty years.

The outgroups included eight genera and 11 species, three of them members of Peripatopsidae, Peripatopsis moseleyi (Wood-Mason, 1879), P. lawrencei McDonald, Ruhberg \& Daniels, 2012, and Metaperipatus inae Mayer, 2005. The other eight belong to Peripatidae, such as Mesoperipatus tholloni (Bouvier, 1898) from Africa and Eoperipatus cf. hosti from Malaysia. We obtained 
morphological data for Principapillatus hitoyensis Oliveira et al., 2012 through the literature. Specimens with poor morphological preservation or incomplete molecular data were excluded from the final analyses. Despite their importance, the Brazilian specimens of Cerradopatus sucuriuensis Oliveira et al., 2015 were not available for examination. Therefore, the solution was to use literature information and GenBank sequences in the present analyses. Moreover, we included in the analyses the original sequences of E. adenocryptus, E. diadenoprocutus and E. paurognostus (deposited in GenBank database. See table S.1).

Phylogenetic inference: A debate about of the use of parsimony versus probabilistic methods (Optimality criteria) is found in the literature (Frost et al. 2006, Rindall \& Brower 2011, Wheeler 2012, Giribet \& Edgecombe 2013). Weighing in on this debate is not our objective, although we test the sensitivity of our dataset using two different optimality criteria: parsimony (normally referred as maximum-parsimony; MP) and maximum-likelihood (ML). Behind the differences of what is being minimized in unweighted MP and ML lies a profound difference in the philosophical and theoretical foundations of each method (for more details see Padial et al. 2014). Therefore, the comparison between the results of these criteria cannot add to the support of one hypothesis (cladogram). In fact, Rindall \& Brower (2011) argues that the usage of multiple optimality criteria is largely superfluous given that it has been already observed that results of these methods are frequently similar, with differences resting only in clades that are weakly supported.

Although comparisons among cladograms obtained with MP and ML do not add to the support of a hypothesis, the sensitivity of the data to different optimality criteria may indicate that method choice will give little influence to the results; also it can be useful to readers interested in comparing competing methodologies. Wherever the results obtained by both criteria diverge, we adopted the MP analysis due its methodological clarity and interpretability. In addition, we selected our working hypothesis as the total evidence method to consider it would bring more informative and comparable results than the isolated phylogenetic analyses of solely morphological or genetic data (Dikow 2009, Kluge 1989, Kluge 2004). Our decisions considered the methodological clarity of parsimony methods and the ample support found in literature (Frost et al. 2006, Rindall \& Brower 2011). However, we also show the results of ML analyses and comment on the differences between the results obtained from both criteria. 
Table 2. Species obtained.

Taxon

Locality

N number Morphology DNA Source

Peripatopsis moseleyi (Wood-Mason 1879) South Africa, Eastern Cape; Keiskammahoek

Family Peripatosidae

Bouvier 1905 Metaperipatus inae Mayer 2005 Chile, Araucania

\begin{tabular}{|c|c|c|c|c|c|}
\hline Bouvier 1905 & Metaperipatus inae Mayer 2005 Chile, Araucania & 1 & - & - & $\mathrm{c}$ \\
\hline \multirow{27}{*}{$\begin{array}{c}\text { Family Peripatidae } \\
\text { Evans } 1901\end{array}$} & Eoperipatus cf. horsti Malaysia, Terengganu, Pulau Perhentian Besar & 1 & $\bullet$ & $\bullet$ & $\mathrm{c}$ \\
\hline & Mesoperipatus tholloni (Bouvier 1898) Gabon, Moyen Ogooué Province and Ogooué & 5 & $\bullet$ & $\bullet$ & $\mathrm{c}$ \\
\hline & Oroperipatus corradoi (Camerano 1898) Equador, Esmeralda & 3 & - & • & $\mathrm{c}$ \\
\hline & Peripatus bouvieri Fuhrmann 1913 Colombia, Cundinamarca & 3 & • & - & $\mathrm{c}$ \\
\hline & Peripatus cf. basilensis Dominican Republic & 1 & • & • & $\mathrm{c}$ \\
\hline & P. solorzanoi Morera-Brenes \& Monge-Nájera 2010 Costa Rica, Heredia & 2 & • & • & $\mathrm{c}$ \\
\hline & Principapillatus hitoyensis Oliveira et al. 2012 Costa Rica, Province of Limón & 1 & • & • & $\mathrm{c}$ \\
\hline & Cerradopatus sucuriuensis Oliveira et al. 2015 Brazil, Mato Grosso do Sul state, Chapadão do Sul & 0 & 0 & • & $\mathrm{g}$ \\
\hline & Epiperipatus edwardsii (Blanchard 1847) French Guiana, Nouragues Field Station & 1 & - & - & $\mathrm{c}$ \\
\hline & E. trinidadensis (Sedgwick 1888) ${ }^{1}$ Trinidad island & 1 & • & o & * \\
\hline & E. imthurni (Sclater 1888) ${ }^{1}$ Guyana, Wakapoa & 4 & - & o & $*$ \\
\hline & E. brasiliensis (Bouvier 1899) ${ }^{1}$ Brazil, Pará state, Santarém & 1 & $\bullet$ & ० & $*$ \\
\hline & E. ohausi (Bouvier 1900) Brazil, Rio de Janeiro state, Nova Iguaçu & 3 & - & - & $\mathrm{c}$ \\
\hline & E. biolleyi (Bouvier 1902) Costa Rica, San José & 2 & • & • & $\mathrm{c}$ \\
\hline & E. evansi (Bouvier 1904) ${ }^{1}$ Guyana, Demerara & 1 & $\bullet$ & $\circ$ & $*$ \\
\hline & E. isthimicola (Bouvier 1902) Costa Rica, San José & 1 & $\bullet$ & $\bullet$ & $\mathrm{c}$ \\
\hline & E. betheli (Cockerell 1913) ${ }^{1}$ Tobago island & 3 & • & o & $*$ \\
\hline & E. vespuccii Brues $1914^{1}$ Colombia, Santa Marta & 3 & • & o & * \\
\hline & E.vagans Brues $1925^{1}$ Panama, Barro Colorado, Colón & 14 & - & • & * \\
\hline & E. acacioi (Marcus and Marcus 1955) Brazil, Minas Gerais state & 41 & • & • & $\mathrm{c}$ \\
\hline & E. tucupi Froehlich $1968^{1}$ Brazil, Pará state & 3 & • & $\circ$ & */type \\
\hline & E. machadoi (Oliveira and Wieloch 2005) Brazil, Minas Gerais state, Caratinga & 18 & - & - & $\mathrm{c}$ \\
\hline & E. cratensis Brito et al. 2010 Brazil, Ceará state, Crato, APA do Araripe & 1 & - & - & $\mathrm{c}$ \\
\hline & - $\quad$ Brazil, Ceará state, Crato, FLONA do Araripe & 4 & - & - & $\mathrm{c}$ \\
\hline & E. adenocryptus Oliveira et al. 2011 Brazil, Minas Gerais state, Santa Bárbara do Leste & 7 & - & - & $\mathrm{c}$ \\
\hline & E. diadenoproctus Oliveira et al. 2011 Brazil, Minas Gerais state, Simonésia & 7 & - & - & $\mathrm{c}$ \\
\hline & E. paurognostus Oliveira et al. 2011 Brazil, Minas Gerais state, Piedade de Caratinga & 6 & - & - & $\mathrm{c}$ \\
\hline
\end{tabular}


Phylogenetic protocols: We used tree datasets. One dataset included only morphological data, one considered only molecular data, and the last provided the simultaneous analyses of morphological and molecular data within the context of total evidence (Dikow, 2009, Kluge 1989, Kluge 2004). For each of these datasets we applied different optimality criteria. As such, phylogenetic inferences based on morphological and total evidence datasets were performed under MP criterion, whereas the molecular dataset was evaluated under both MP and ML frameworks.

Static homology: We implemented one parsimony analysis based on static homology using TNT (Goloboff et al. 2003) exclusively for morphological data. As we compiled the morphological characters, we constructed a matrix using MorphoBank (version 3.0, O'Leary \& Kaufman 2011, 2012). Subsequently the MorphoBank matrix was exported, then edited in Mesquite (version 3.02, Maddison \& Maddison 2015) and then exported as Nexus and TNT file formats. Tree search was implemented according the following parameters: hold 10000, no drift, replications 100, hold 1000, ratchet 10 and fuse 10 . We considered only one individual of each recognized species; poorly preserved and extra samples were removed from the morphological matrix. We performed this analysis for eighty-one terminals and included missing data.

Maximum Likelihood: For ML analysis, sequences were aligned by MAFFT and concatenated in SequenceMatrix (Vaidya et al. 2011). The ML search was implemented in RAxML (version 8.1.11, Stamatakis 2014) via the CIPRES Science Gateway (Miller et al. 2010). Analyses were run under a partitioned GTRGAMMA model specifying each partition by gene and further by codon position within COI (positions 1 and 2 composed a single partition while position 3 had its own). Only those clades with a bootstrap support of 100 (high support hereafter) were considered for comparison to parsimony results. The ML analysis was based on the molecular dataset, including missing data. The tree obtained was edited with Figtree (http://tree.bio.ed.ac.uk/software/figtree/).

Dynamic Homology: We partitioned the sequence data of all markers to help reduced the effect of short sequences downloaded from GenBank and to reduce the computational time of phylogenetic analysis (Giribet 2001, Wheeler et al. 2006). Hence, we searched for conservative regions to divide them into homologous small fragments. These parameters and partitions were utilized in all three POY analyses. We implemented Optimization Alignment under MP criterion by direct optimization of nucleotide data (DO, sensu Wheeler 1996) and then rediagnosed trees compiled during DO using Iterative Pass (IP) method (Wheeler 1996) in POY (version 5.1.1, Varón et al. 2010). The sensitivity analysis under POY was run on the Zoology parallel computing cluster using 20 processors at the Bioscience Institute of the Department of Zoology at the University of São Paulo. Five iterations were ran, two cycles of timed searches of one hour each were run under equal costs for indel opening, extension and transversions in all partitions. 
We offer the results of branch lengths, bootstrap and Goodman-Bremer values for the cladograms of the MP of molecular data (Supplementary Information), while for ML, we offer only bootstrap values. Branch lengths in the trees selected using ML analysis correspond to the expected substitutions per site. Branch lengths in the shortest trees from MP analysis are the number of transformations. We mapped the distribution of characters under MP with the program YBYRÁ (Machado 2015). In the topology, clades not supported by any transformation event or absent on each binary tree were collapsed by YBYRÁ. This program categorized ambiguous and unambiguous (i.e., optimization dependent) synapomorphies in all trees. Unambiguous synapomorphies are later categorized into three groups: unique and un-reversed (non-homoplastic), unique (homoplastic, a private stated that is not shared by all terminals derived from the corresponding node), and non-unique (a homoplastic non-private state) (Machado 2015).

\section{RESULTS}

All the analyses relied on 7 genera and 26 species; four of which were type-species (see Table 2). Among the Epiperipatus species, we examined 18 species, however only 11 were included on the phylogenetic analyses, due to the better preservation condition.

Morphological data: the MP analyses considered 33 characters compiled from structures of the integument (dorsal papillae), jaw (inner and outer blades), legs (spinous pad, foot papillae and nephridial tubercles), dimorphic characters (crural papillae and anal gland that are exclusive of males), with most of the characters focused on Peripatidae. The characters were selected if they occur in the current literature of onychophorans and used in diagnosis of the genus, or present in a group of specimens examined. Autapomorphies were not coded on the matrix (See Supplementary Information, Table S.2). The descriptions of characters coded in the matrix are presented in the List of Characters (See Supplementary Information).

Missing data and total evidence: the MP and ML analyses included the specimens sequenced and listed in Table S.1. For Epiperipatus, we obtained data for 140 specimens, including the unidentified specimens. However, in total we obtained molecular data for 175 specimens, including GenBank data (see Table S.1). Four genetic loci were sequenced for both ingroup and outgroup; details can be found in Table 1. Overall we obtained COI data from 136 specimens (20 from GenBank), 158 specimens (20 from GenBank) for 12S, 134 specimens for 16S and lastly 91 specimens for $18 \mathrm{~S}$. The MP total evidence analysis included the same molecular data in addition to morphological data for 131 specimens. 
Topologies. For MP analyses, 100 most parsimonious trees (MPT; score 91) were found under static homology. For dynamic homology, 23 MPT (score 6543) were found for the exclusive analysis for molecular data, while 28 MPT (score 6715) were found for the total evidence analysis. All results, except for the static homology analysis (Figure S.2), rendered completely resolved topologies for Peripatidae groups. The exceptions (small polytomies) occurred only among terminals of the same species and morphotypes. The MP and ML analyses based on molecular data alone showed two major Neotropical clades (Figure 1). The partially assembled clade is composed of the "andicoles", represented by the Oroperipatus species as sister group to the "caraïbes" onychophorans (Figure 1).

Moreover, our working hypothesis (Figure 2) corroborates the group "caraïbes" as a large clade formed by all other Neotropical species, including Epiperipatus. Four major ecoregions (Andean, Caribbean, Central American and South American) were congruent with the phylogenetic pattern recovered (Figure 2). The group "Andicoles" from Ecuador were predictably found in the Andean ecoregion. The "caraïbes" clade is distributed across three major ecoregions: Caribbean, Central American and South American (see clade D in Figure 1; and Figure 2). The Central American ecoregion (clades $\mathrm{K}$ and $\mathrm{H}$ ) is comprised by specimens from Costa Rica, Panama, that is, member of Puntarenas-Chiriqui, Guajira and Mosquito biogeographical provinces. In South America, we found groups of onychophorans from the ecoregions Magdalena, Ecuadorian, Roraima, Pará, Madeira, Xingu-Tapajós, Caatinga, Cerrado and Atlantic provinces (Figure 2 clades G, I, L and U; province names are according to Morrone 2014).

With a closer look at the "caraïbes" species (Figure 2, clade D), we observe six clades: 1) the Colombian and Northern Brazil group (CNB) - formed by specimens from Colombia and Pará state (clade G); 2) the Northern Brazil (Pará state) and French Guiana group - Brazilian specimens are from Pará state (clade I) and E. edwardsii from French Guiana; 3) Central and South American group (CPB) - composed of species from Costa Rica, Panama, Colombia and French Guiana (clade H); 4) a small group formed by E. vagans and their closest relatives - composed of specimens from Central region of Panama (clade K); 5) a large Brazilian group (clade L); and 6) a small group formed by Epiperipatus n. sp. [sp10] and their close relatives (clade U).

MP and ML molecular analyses suggested that the group CNB is sister to all other "caraïbes" species (clade F), however there were minor differences of internal branches between both analyses. The analysis based on molecular alone (Figure 1) and total evidence analyses (Figure 2) differed on the position of the E. edwardsii clade (clade I), E. vagans clade (clade K) and E. n. sp [sp10] [ony_079 to 83] clade (clade $U$ ). Moreover, none of them is supported by the molecular data in the total evidence analysis. This discrepancy does not seem to influence our overall results, yet the phylogenetic placement of Epiperipatus edwardsii is uncertain. Nevertheless, E. edwardsii is nested in clade I and 
it is clearly part of an Amazonian clade across all topologies. The phylogenetic condition of Epiperipatus is unchanged, which is recovered paraphyletic due to Peripatus bouvieri (clade G), Peripatus solorzanoi, Principapillatus hitoyensis (both on clade $\mathrm{H}$ ) and Cerradopatus sucuriuensis (clade L) nested within the Epiperipatus clade.

Total evidence analysis. POY found 28 most parsimonious trees that differed solely on the arrangement of apical intraspecific terminals (score 6715). Peripatidae resulted as monophyletic as Figure 1 and 2. The "caraïbes" group is composed by specimens from Brazil, Colombia, Costa Rica, Dominican Republic and Panama (clade D). The Peripatus species, Peripatus basilensis, P. bouvieri, and $P$. solorzanoi, nested in independent clades (in Figure 1, clades G, F and H respectively). $P$. hitoyensis nested, as expected, closely related to Epiperipatus isthmicola (clade $\mathrm{H}$ ), as is $C$. sucuriuensis to Epiperipatus acacioi (clade T).

Based on the results, Epiperipatus is the most widespread Neotropical genus spanning the bioregions of Amazonia, Caribbean, Central America, Eastern South America, Northern Andes, Orinoco and Southern South America. Epiperipatus edwardsii (the type species) was recovered as sister to another species from the Amazon (Figure 2, Epiperipatus [sp4]). E. biolleyi, E. acacioi, E. cratensis, E. isthmicola and E. ohausi were recovered as monophyletic species. Conversely, E. adenocryptus, E. diadenoproctus and E. paurognostus occur in four clades, one for each species and the fourth composed of a combination of the three species (Figure 2). Fifteen morphotypes could be identified from the topology, but only seven are morphologically distinct: 1) Epiperipatus n. sp. [sp10] (ony_079 to 082), 2) Epiperipatus n. sp. [morfosp15] (ony_148 and 149), 3) Epiperipatus n. sp. [sp16] (ony_002 and 051), 4) Epiperipatus n. sp. [sp1] (ony_045, 046 and 109), 5) Epiperipatus n. sp. [sp2] (ony_041, 044, 047 and 108), 6) Epiperipatus n. sp. [sp17] (040, 043 and 107) and 7) Epiperipatus n. sp. [troglobius] (ony_020). Additionally, there are cases of recognizable clades with overlapping morphology between the morphotypes. For example, the delimitation is unclear among the Epiperipatus [sp11] (ony_003, 027a to 027c), Epiperipatus [sp12] (ony_048) and Epiperipatus [sp13] (ony_029, 030a and 030b).

The topologies based on total evidence and the molecular data also differed, which suggests that the morphological data is relevant to phylogenetic inference of this group. In general, both analyses showed the same order of clade divergences. Within Peripatidae it was only possible to recognize a few Neotropical genera, which will be discussed below. Apart from Epiperipatus, the generic delimitation of Peripatus solorzanoi, P. bouvieri, P. hitoyensis and Cerradoperipatus sucuriuensis were not clarified and must be reviewed. 


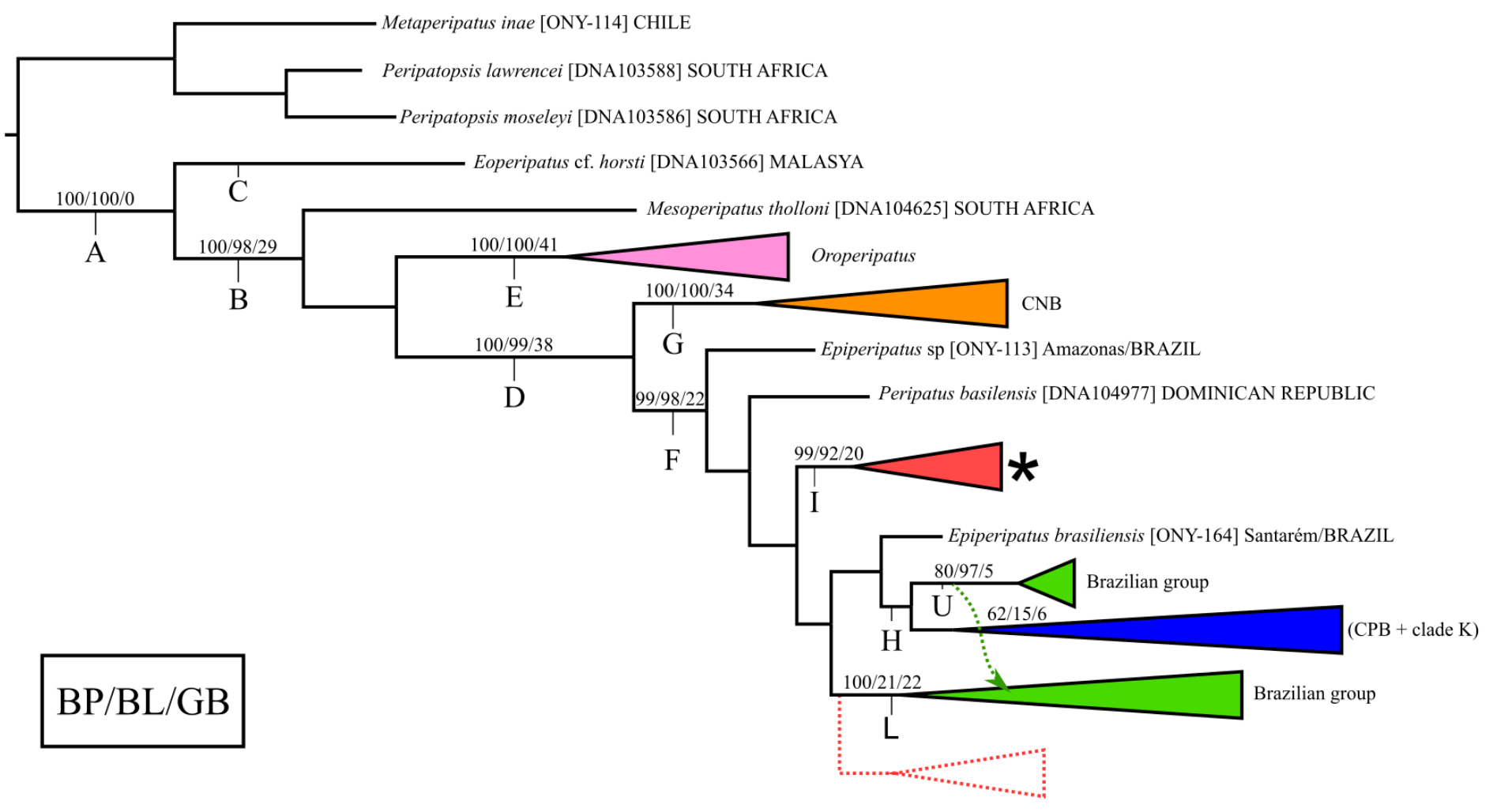

Figure 1. Condensed tree of Maximum parsimony and Maximum Likelihood based on molecular-only dataset. The Bootstrap values for parsimony (BP) and maximum likehood (BL), and Goodman-Bremer for parsimony (GB) are Present by the most inclusive clades of the topology. Clades B, D, E and G do not have large differences among the bootstrap values. Contrary, clade F shows Presents less BL values. In BP and BL, the clade F shows different topology. Some clades show uncertainty relationship such as clades H, I, L and U, besides to differ in their bootstrap values. For BL, the position of clade $\mathrm{I}$ and $\mathrm{U}$ is indicated through the arrow and clade (both dashed). On this topology, groups "andicoles" and "caraïbes" are show in clades E and D respectively. The Neotropical clades on the topology are named as follow. Pink clade: Oroperipatus. Light brown: Colombia and North Brazil (CNB). Light red: Epiperipatus edwardsii (the position indicated with asterisk *) clade. Clade blue (CPB): Colombia, Costa Rica, French Guiana and Panama. The $E$. vagans and their species related are nested in this clade. Green clades: Brazilian clades. 


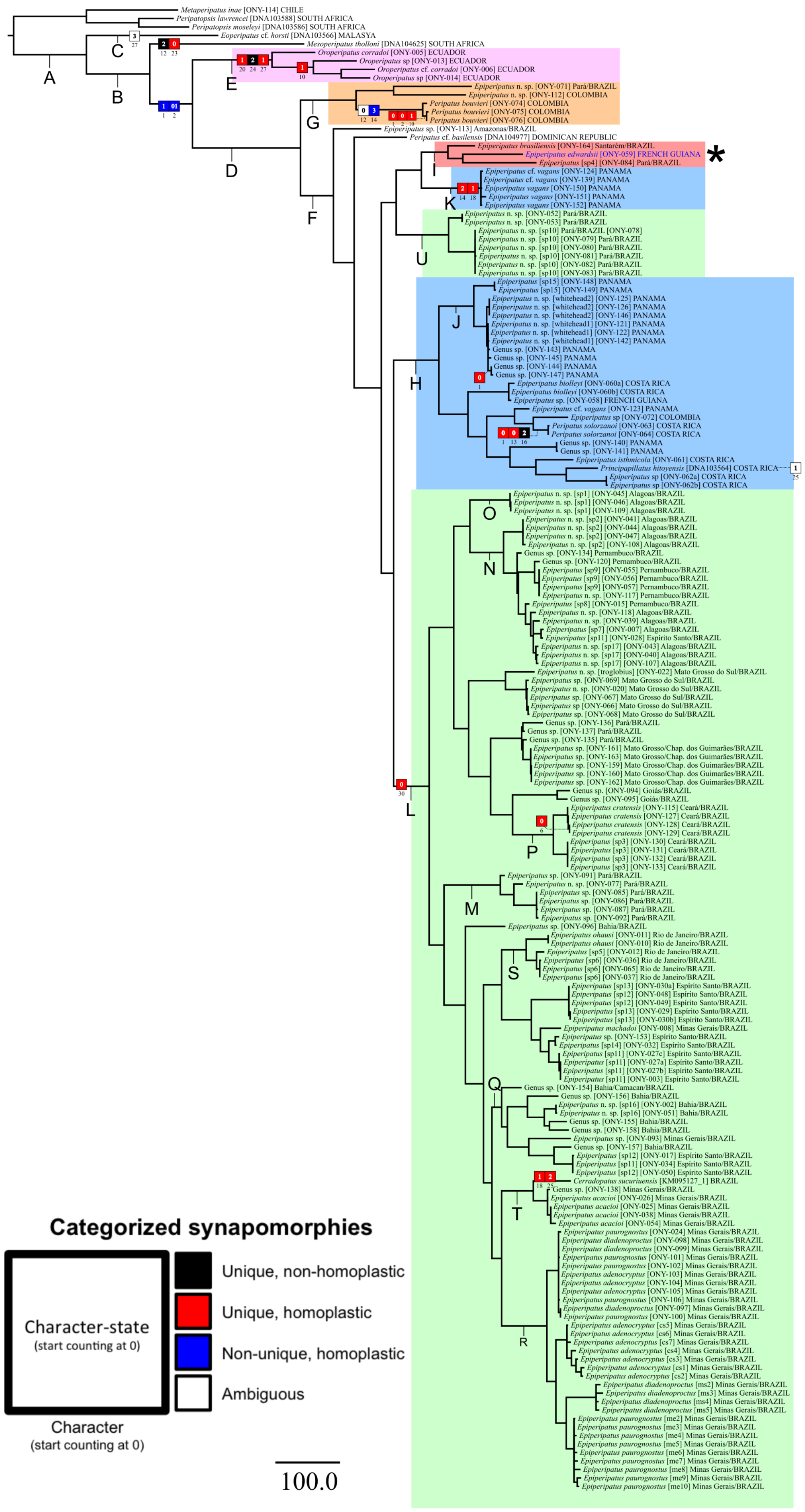


Figure 2. Cladogram to 175 terminals using matrices from incomplete morphological and molecular data (for subunits COI, 12S, 16S and 18S), and analyzed in POY (score 6715). The topology was rooted in Peripatopsidae. In the topology is detailed the morphology mapping through YBYRÁ. The unambiguous synapomorphies mapped for P. solorzanoi, P. bouvieri, and clades Neotropic (D+E), E and L are the same checked in Table S.4. The morphological synapomorphies were mapped for branches and terminal. Different colors stand for diverse groupings: Purple - Oroperipatus; Light brown - Colombia and North Brazil; Light red - North Brazil and French Guiana; Blue - Costa Rica and Panama; Green - Brazilian groups. E. edwardsii - the asterisk indicate their position. In the clade $\mathrm{H}$, note that P. hitoyensis, E. isthmicola and P. solorzanoi in the same clade. Moreover, note C. sucuriuensis and E. acacioi close related in clade T. Sequences from GenBank: C. sucuriuensis, cs1 to cs7, ms2 to ms5 and me2 to me10. 
Morphology and Molecular support in total evidence analysis: At least 19 of the 33 morphological characters were shown to be phylogenetically informative (See Figure S.3). Few groups were supported by morphology. Among the major clades, Peripatidae was not supported (see Figure S.3; clades "D+E", C and Eoperiperipatus cf. horsti). The Neotropical group was supported by two non-unique, homoplastic synapomorphies (clade $\mathrm{D}+\mathrm{E}$ : character 1 state 1; character 2 states 0 and 1), but their internal relationships remained unresolved. Oroperipatus (clade E) was supported by one exclusive synapomorphy (character 24 state 2 ) and two unique, homoplastic synapomorphies (characters 20 state 1 and character 27 state 1). Among the large "caraïbes" groups, only two clades $\mathrm{K}$ and $\mathrm{L}$ were supported though morphological synapomorphies. Both clades are supported by unique, homoplastic synapormorphies. The clade $\mathrm{K}$ is supported by two unique (See Figure 2 and Figure S.3; characters 14 state 2 , and character 18 state 1 ), homoplastic synapomorphies, while clade L is supported by one unique, homoplastic synapomorphies (See Figure 2; characters 30 state 0). Epiperipatus and Peripatus were not supported for any morphological character. However, E. cratensis, P. bouvieri, Peripatus solorzanoi and Genus sp (Figure S.3, Genus sp. Panama) were supported by morphological characters (See Figure 1, Figure S.3 and Table S.3).

Contrary to morphological characters, we found a large number of clades supported by molecular data. The major groups have a high number of unambiguous synapomorphies (Table S.3). Therefore, Peripatidae and their internal groups can be supported based on different data. For example, Oroperipatus was supported in all datasets. In our working hypothesis we delimited Epiperipatus in clade D (Figure 2), which was only supported through the four molecular markers (Table S.3). Among the new species, they were supported only by molecular characters (See Table S.3).

\section{DISCUSSION}

Implications for the systematics of Epiperipatus: Onychophora has an exceptionally conservative morphology (Bouvier 1899, Briscoe \& Tait 1995, Tait \& Norman 2001, Daniels et al. 2009), which makes it difficult to delimit genera based on morphology alone. Many misinterpretations occur in Peripatidae, probably due to the fact that previous studies have not attempted to revise and redescribe the genera of Peripatidae morphologically (Oliveira et al 2005, Oliveira et al 2010, Chagas-Junior \& Costa 2014, Murienne et al. 2014). Our results corroborate the hypothesis of a conservative morphology in Onychophora. We do not believe in a large diversity of genera for Peripatidae, since the results suggest only a few morphological groups in the Neotropics.

Approximately $90 \%$ of Peripatidae diversity is found in Central and South America. The American genera are weakly delimited by ambiguous characters. This is specifically true for the 
Caribbean group, which is circumscribed on the basis of three external characters (namely, the distribution of papillae on the dorsal integument, scale ranks on the primary papillae, and the number of crural papillae per pregenital leg) (Bouvier 1899, Read 1988a, Sampaio-Costa et al. 2009). The morphological conservatism directly affects the taxonomy of the genera of Peripatidae, which are supported by variations of four main structures: plicae, dorsal papillae, jaws and legs. The main question should therefore be why are Peripatidae genera so weakly delimited? In our opinion, the reason is that molecular data conflicts with characters traditionally used to define genera within Peripatidae.

Epiperipatus remains poorly characterized since Bouvier's (1905) monograph on Peripatidae. Clark (1913) and Peck (1975) provided weak theoretical approaches to raise informally the American Peripatidae to generic level. Read (1988a, 1988b) proposed to delimit the Neotropical onychophorans counting the range of scale ranks on the primary papillae. Lacorte et al. (2011) have proposed a boundary (circa of 11 to $50 \mathrm{Km}$ separating each species) in allopatric patterns of distribution of some Brazilian species (recognized through molecular approaches), which was reiterated by Oliveira et al (2012a). After that, E. adenocryptus and E. paurognostus were recognized with the use of statistical models (Oliveira et al 2011).

Contrary to these authors, the monophyly of the specimens [ony_024], [ony_098], [ony_099], and [ony_101] to [ony_106] was recovered. However, in our results the monophyly of $E$. adenocryptus, E. diadenoproctus and E. paurognostus was questioned, although it could be a technical artifact of the analysis, resulting from missing data. Comparatively, the GenBank sequences could be grouped together due to the size and amount of missing data compared to the sequences generated for this study, which were larger and represented more than two loci (no data was available on GenBank for $16 \mathrm{~S}$ and $18 \mathrm{~S}$ ). Moreover, it is possible that this small amount of data (shorter sequence) available in GenBank is contributing for the lack of support for the monophyly of these three species.

The results presented here do not corroborate the dispersal hypothesis suggested by Lacorte et al. (2011). For example, recently E. ohausi was collected in a locality $28 \mathrm{~km}$ from the type locality (Petrópolis), suggesting that this species has a more widespread distribution than is currently known. Additionally, Epiperipatus n. sp. [sp2], Epiperipatus n. sp. [sp1] and Epiperipatus n. sp. [sp17] are examples of species with sympatric distributions. These three new species were found in a single rotten log (45 specimens) at Estação Ecológica de Murici (Alagoas state), and an additional record, collected $35 \mathrm{~km}$ away from to type-locality was found for Epiperipatus n. sp. [sp17].

The monophyly of the clades Principapillatus hitoyiensis and Cerradopatus sucuriuensis were 
supported by our results based on simultaneous analyses of morphological and molecular data (Figure 1), and molecular data alone. However, we think that these species were delimited based on a combination of characters, most of which are shared by species within Epiperipatus (see the diagnosis in Oliveira et al. 2012b, 2015). Fifteen of those characters proposed in the description of $P$. hitoyiensis and $C$. sucuriuensis failed as informative characters on the phylogenetic analysis presented here (Figure 1). Seven of them were compared and we did not find difference among all 200 specimens examined.

Among the new species and unidentified morphotypes, differences were searched in the head dorsal patterns, antennal rings and sensory appendages, oral lips, slime papillae, distal legs patterns, crater-shaped papillae, ventral and preventral organs, and anal glands.

For the species examined, the dorsal patterns on the head do not show any phylogenetic signal. Some species of Peripatopsidae have a depression, resembling a fovea or papillae, with a modified, horn-like shape on the head (Reid 1996). On the other hand, among Peripatidae species, the pattern on the head described in the literature is unclear. In fact, it is hard to understand and codify in a morphological matrix the arrangement of dorsal papillae on the head (Oliveira et al. 2012b).

We examined the dorsal head region for twenty-nine specimens of Peripatidae, and we found only random distribution of the dorsal papillae and weak plicae. The structures, antennal rings and its sensory appendages, body ventral anatomy, dorsal leg area, and embryonic structures were presented as unexplored alternative taxonomic characters (Oliveira et al. 2012b). Unsatisfactory results were obtained for antennal rings and its sensory appendages. We were not able to replicate the results obtained by Oliveira et al. $(2012$ b, 2013, 2015). It is likely that there is no correspondence among the antennal rings on antennae of Peripatidae species, since the antennal rings vary in number inter- and intraspecifically. There is no phylogenetic signal on the dorsal area of the legs for the 29 species examined here. This area of the legs is likely to be affected by fixation methods and display large variation in the shape of papillae. Mouth and the slim gland structures seem invariable in all examined species. Consequently, we avoided these characters in our phylogenetic studies, although they might be interesting for species description.

The morphology contributed to the results as noticed in MP analyses (compare Figures 1 and 2). However, we noticed a large number of “caraïbes" specimens sharing characters used in genera delimitation. For example, all species included in this study share the presence of primary papillae in all dorsal plicae (Character 11, state 1; see Table S.2 and List S.3), with the exception of Epiperipatus n. sp. [troglobius] [ony_022]. Another example, at least in E. edwardsii, E. isthmicola and E. machadoi can be present the fourth spinous pad broken. Therefore, the total evidence analysis shows 
lack of morphological support for "caraïbes" genera included in this study, excepted C. sucuriuensis and P. hitoyensis (Figure 1).

Our working hypothesis allow the delimitation of Epiperipatus. As a cautionary measure, and avoiding paraphyletic condition, it was assumed that all terminals inserted in clade D of the MP analysis belong to Epiperipatus. The results gathered do not support the Cerradopatus, Principapillatus, Peripatus bouvieri and Peripatus solorzanoi as all appear nested within the Epiperipatus clade (Figure 1). Consequently, C. sucuriuensis, P. bouvieri, P. dominicae, P. solorzanoi, P. hitoyensis should also be transferred to Epiperipatus.

Our results corroborated valid status of $P$. hitoyensis and $C$. sucuriuensis, but diverges from the paraphyletic Epiperipatus proposed by Oliveira et al. (2012b, 2015). Our study constitutes the largest onychophoran dataset to date and the results suggest all clade D belong to one genus only, in this case Epiperipatus. That diversity seems to be concentrated in five Neotropical genera. The most diverse genus within the family is Epiperipatus, which was considered to be paraphyletic, but here is redefined to include several other genera. There is no morphological support to explain the high number genera among the New World onychophorans. Prudently, it could be better to reduce the number of genera for this family. Aiming to solve the paraphyletic condition of Epiperipatus, here we suggest synonymized Principapillatus and Cerradopatus with Epiperipatus. There is no doubt about their richness and wide range of distribution. Bootstrap values supported Epiperipatus as a clade (88 in parsimony and 100 in maximum likelihood). Consequently, C. sucuriuensis, P. bouvieri, P. solorzanoi, P. hitoyensis should be transferred to Epiperipatus.

Groups from Eastern South America. Brazil is one of the most diverse in type of biomes and Amazonia is one of them. This biome is formed by a mosaic of areas of endemism, each of which with their own evolutionary relationship and biotic assemblages (Silva et al. 2005). Currently, Amazonia is divided in eight areas of endemism (Borges \& Silva 2012): Belém, Tapajós, Xingu, Rondônia, Inambari, Napo, Imeri and Guiana. The riverine barriers may have been important in shaping the current distribution patterns of diverse groups of animals which include invertebrates and vertebrates (Silva et al. 2005, Hall \& Harvey 2002).

The total evidence analysis showed unexpected results. Two species from Belém formed a clade, while another one occurred in an independent clade, inside of the large Brazilian group. Species from Tapajós were observed in four independent groups, three of them nested in Brazilian clade and the other one related with Colombia species (Figure 2). Epiperipatus sp. [ony_113] is a unique species from Guiana area. Genus sp [ony_135 to 137], from Tapajós area, resulted in sister group of Epiperipatus sp. [ony_159 to 163] from the state of Mato Grosso (Cerrado). The others species from 
Tapajós area were observed in independent clades (Figure 2, inside of clade L). Hence, ours results do not show correlation among the South American areas of Endemism. It is unclear the importance of the barriers in a dispersion and relationships among groups of onychophorans from Amazonia. As noticed, seven species of Amazonia nested in different positions of the cladogram. Among clades from Amazonia, only species from Belém area of endemism seem to be closely related among each one. Epiperipatus n. sp. [ony_052], Epiperipatus n. sp. [ony_053] and Epiperipatus n. sp. [sp10] [ony_078 to 82] formed an exclusive group (Figure 2, clade U), although Epiperipatus [sp4] [ony_084] occur in a different clade (Figure 2, clade I).

Likewise, among the five species from Cerrado, only two of them have close relationships with each other. For example, they all nested in the Brazilian clade into three independent groups (Figure 2). Epiperipatus n. sp [troglobius] [ony_022]; Epiperipatus n. sp. [ony_020] and Epiperipatus sp. [66 to 68] and Genus sp [ony_159 to 163] from Mato Grosso formed a monophyletic group. Epiperipatus sp. [ony_159 to 162] nested in a second clade, sister to Genus sp [ony_135 to 137]. Finally, $C$. sucuriuensis [ONY-MTS08], from Mato Grosso do Sul, resulted as sister to E. acacioi which occurs in region marked a mix of Cerrado and Atlantic rain forest biomes.

Morphology and Molecular delimitation. This result shows that morphological data alone cannot be used to resolve the phylogenetic relationships of this group (figure S3), since the number of characters and the distribution of character states are insufficient to solve any topology showed here. It means that "andicoles" and "caraïbes" clades are supported by the molecular data in the total evidence analyses. However, Epiperipatus was supported through the four molecular markers as previous discussed. Epiperipatus was supported by a large number of molecular synapomorphies from all molecular markers (Table S.3). Epiperipatus rely with unambiguous synapomorphies for COI in seven positions, for $12 \mathrm{~S}$ in 26 positions, for $16 \mathrm{~S}$ in 14 positions and for $18 \mathrm{~S}$ in a single position. Hence of the new delimitation of Epiperipatus, the generic delimitation of the species $P$. solorzanoi, P. bouvieri, P. hitoyensis and C. sucuriuensis were clarified and reviewed.

Based on the above findings, the genus Epiperipatus is delimited with molecular synapomorphies, although morphologically this genus is delimited by a combination of symplesiomorphies as follows: twelve complete or incomplete dorsal plicae with regular width. When incomplete (they are only two) elongating until the long axis (anterior-posterior) in sagittal view. Dorsal papillae with roundish insertion and dome shape basal piece. Primary papillae showing asymmetrical or symmetrical apical piece, in a variety of shapes: conical, cylindrical and (rarely) flat. A range of scale ranks vary from four to eighteenth on the basal piece. The bristle can be moved to a posterior region of the apical piece, or on top of it. Four, rarely five, spinous pads occur on the fourth and the fifth pair of legs. A fifth spinous pad, when it is present, which is always reduced compared 
with the anterior spinous pad. A nephridial tubercle occurs on the fourth and the fifth pair of legs, between the third and the fourth spinous pads. Moreover, there are two pro-lateral and one retrolateral foot papillae on the feet of the fourth and fifth legs.

\section{SUGGESTED TAXONOMIC ACTS}

According to our findings, we propose the new combination for four species. Moreover, the combinations of COI, $12 \mathrm{~S}, 16 \mathrm{~S}$ and $18 \mathrm{~S}$ sequences allowed identifying five new species. Epiperipatus [sp1] n. sp, Epiperipatus [sp2] n. sp. and Epiperipatus [sp17] share the same type locality, the Estação Ecológica de Murici in Alagoas state (Brazil). Epiperipatus [sp10] n sp. occurs in Marajó Island, in Pará state and Epiperipatus [sp16] is the first species record to Bahia state. Each species have a large number of exclusive nucleotide identities as described below.

\section{Family Peripatidae Evans, 1901}

Genus Epiperipatus Clark, 1913

Synonyms: Principapillatus Oliveira et al., 2012b: 11 n. syn.

Cerradopatus Oliveira et al., 2015: 216 n. syn.

Diagnostic molecular characters: Characterized for unambiguous synapomorphies for COI in seven positions, for $12 \mathrm{~S}$ in 26 positions, for $16 \mathrm{~S}$ in 14 positions and for $18 \mathrm{~S}$ in a single position (see Table S.3).

Distribution: Neotropical

Type-species: Epiperipatus edwardsii (Blanchard, 1847)

1) Epiperipatus bouvieri (Fuhrmann, 1913) n. comb.

Synonyms: Peripatus bouvieri Fuhrmann, 1913: 245; Peck 1975: 348; Oliveira et al.: 2012a: 24

Examined material: ICN-ONY-13; 1q; COLOMBIA, Cundinamarca, Soacha, Vereda San Francisco, Granja Ecológica El Porvenir (2.500 m alt.); 17.viii.2009; Luna, D.. leg. ICN-ONY-27 and 28; 19 and 1ठ̊; Colombia, Cundinamarca, San Antonio del Tequendama, Reserva Los Tunos; 
28.v.2012; Chagas-Junior, A. and Chaparro, E. leg.

Diagnostic molecular characters: Characterized for unambiguous synapomorphies for COI in 33 positions, for $12 \mathrm{~S}$ in 26 positions, for $16 \mathrm{~S}$ in 13 positions and for $18 \mathrm{~S}$ in 15 positions (see Table S.3).

Type locality: Colombia, Boca del Monte.

2) Epiperipatus solorzanoi (Morera-Brenes \& Monge-Nájera, 2010) n. comb.

Synonyms: Peripatus solorzanoi Morera-Brenes \& Monge-Nájera, 2010: 979; Oliveira et al.: 2012a: 27.

Diagnostic molecular characters: There is no molecular diagnosis for this species; although it is supported through three morphological characters (see Table S.3).

Examined material: MZUSP 0013; 2ᄋ, 1ठ; COSTA RICA, Limón Province, Guayacán de Siquirres; 01-14.ix.2012; Miguel leg.

Type locality: Costa Rica, Limón Province, Guayacán de Siquirres.

3) Epiperipatus hitoyensis (Oliveira et al., 2012) n. comb.

Synonyms: Principapillatus hitoyensis Oliveira et al., 2012b: 11

Examined material: IZ 131339; unsexed 2 body segments; COSTA RICA, neat Limón, Reserva Biologica Hitoy-Cerere; xi.2005; Mayer, G. leg; DNA Reference Code: DNA103564.

Remarks: We only accessed the molecular data of the body segments deposited at MCZ. There is no molecular diagnosis for this species. More details of E. hitoyensis see Oliveira et al. (2012b).

Type locality: Costa Rica, Limón Province, Reserva Biologica Hitoy-Cerere.

4) Epiperipatus sucuriuensis (Oliveira et al., 2015) n. comb.

Synonyms: Cerradopatus sucuriuensis Oliveira et al., 2015: 216.

Molecular data accessed: ONY-MTS08; BRAZIL, Mato Grosso do Sul, Chapadão do Sul; xi.2005; Mayer, G. leg; GenBank accession number: KM095121 (COI), KM095127 (12S rRNA).

Remarks: There is no molecular diagnosis for this species presented here. More details of $E$. sucuriuensis see Oliveira et al. (2015). 
Type locality: Brazil, Mato Grosso do Sul state, Chapadão do Sul.

5) Epiperipatus $[\mathrm{sp} 1]$ n. sp. (Brazil, Alagoas state)

This species is represented by one male and two females (MNRJ ony 045 ony 046 and ony 109) from Alagoas state, in Northeastern Brazil. Epiperipatus [sp1] share with Epiperipatus [sp2] and Epiperipatus [sp17] the same type locality (the Estação Ecológica de Murici in Alagoas state (Brazil). See below), making this first example of sympatric occurrence among onychophorans in Northeast Region of Brazil. This species is identified by the base of the primary papillae having six or seven scale ranks. The apical piece is spherical, asymmetric having six or seven scale ranks on anterior region and three scale ranks on the posterior region. The body measurements vary from 26 to $31 \mathrm{~mm}$ long, $3.0 \mathrm{~mm}$ width and $3.0 \mathrm{~mm}$ tall. Intraspecifically, the number of legs vary from 23 to 25 pairs.

Diagnostic molecular characters: Characterized for unambiguous synapomorphies for COI in 17 positions, for $12 \mathrm{~S}$ in 14 positions, for $16 \mathrm{~S}$ in 12 positions and for $18 \mathrm{~S}$ in five positions (see Table S.3).

Type locality: Brazil, Alagoas state, Estação Ecológica de Murici, Murici.

6) Epiperipatus [sp2] n. sp.

This species is represented by one male and three females (MNRJ ony 044, ony 047, ony 108 ; MZUSP ony 041) from Alagoas state, in Northeastern Brazil. It is identified by the number of scale ranks that vary from four to eight scale ranks on the basal piece of the primary papillae. The apical piece is cylindrical, asymmetric and composed of two scale ranks on the posterior region and three scale ranks on the anterior region. The body measurements vary from 13 to $44 \mathrm{~mm}$ long, 1.0 to 4.0 $\mathrm{mm}$ wide and 1.0 to $3.0 \mathrm{~mm}$ tall. Intraspecifically, the number of legs varies from 27 to 31 pairs.

Diagnostic molecular characters: Characterized for unambiguous synapomorphies for COI in 11 positions, for $12 \mathrm{~S}$ in four positions and for $16 \mathrm{~S}$ in four positions (see Table S.3).

Type locality: Brazil, Alagoas state, Estação Ecológica de Murici, Murici.

7) Epiperipatus $[\mathrm{sp} 10]$ n. sp. (Brazil, Pará state)

This species was found comparing the descriptions of Epiperipatus simoni (Bouvier 1899) with new specimens collected in Marajó island, Pará state, in North Brazil. We do not believe that E. simoni is a widespread species (Bouvier 1905, Sampaio-Costa et al. 2009, Peck 1975) and we propose that 
the specimens gathered from this Brazilian locality are examples of a new species. It is represented by five males (MZUSP ony 078 to 83 ) and is characterized by its primary papillae possessing small cylindrical apical piece. The measurements vary from to 27.0 to $34.4 \mathrm{~mm}$ long, 2.0 to $6.0 \mathrm{~mm}$ wide and 1.0 to $6.0 \mathrm{~mm}$ tall. Intraspecifically, the number of legs varies from 27 to 31 pairs.

Diagnostic molecular characters: Characterized for unambiguous synapomorphies only for COI in 21 positions (see Table S.3).

Type locality: Brazil, Pará state, Marajó Island, Breves, Reserva Extrativista Mapuá.

\section{8) Epiperipatus [sp16] n. sp. (Brazil, Bahia state)}

This species is represented by two females (MNRJ ony 007 and MZUSP ony 051) from Bahia state, in Northeastern Brazil. It shares with Epiperipatus [sp17] the same number of scales ranks on the base and the apical piece of the primary papillae, but differs by having an orangish dorsal body background color. Smaller than Epiperipatus [sp17] the body measurements of Epiperipatus [sp16] vary from 35 to $53 \mathrm{~mm}$ long, $2.0 \mathrm{~mm}$ wide and $4.0 \mathrm{~mm}$ tall. Intraspecifically, the number of legs varies from 28 to 30 pairs.

Diagnosis molecular characters: Characterized for unambiguous synapomorphies for $12 \mathrm{~S}$ in eight positions and for $16 \mathrm{~S}$ in eight positions (see Table S.3).

Type locality: Brazil, Bahia state, Camacan, Reserva Particular do Patrimônio Natural Serra Bonita.

9) Epiperipatus [sp17] n. sp. (Brazil, Alagoas state)

This species is represented by three females (MNRJ ony 043 and ony 107; MZUSP ony 040) from Alagoas state, in Northeastern Brazil. Epiperipatus [sp17] is identified by the base of the primary papillae having eight or ten scale ranks. The apical piece is reduced, symmetric having just one scale ranks on anterior and posterior regions. The body measurements vary from 16 to $76 \mathrm{~mm}$ long, 2.5 to $6.0 \mathrm{~mm}$ width and 1.0 to $3.0 \mathrm{~mm}$ tall. Intraspecifically, the number of legs varies from 36 to 39 pairs.

Diagnostic molecular characters: Characterized for unambiguous synapomorphies for COI and $12 \mathrm{~S}$ in one position, and for $16 \mathrm{~S}$ in two positions (see Table S.3).

Type locality: Brazil, Alagoas state, Estação Ecológica de Murici, Murici. 


\section{ACKNOWLEDGEMENTS.}

We are in debit with all collaborators which help us to perform this study. The fact of the difficulty to collect onychophorans we acknowledge many colleagues, which provide samples of all parts of the world. Among them, Jerome Murienne, which provided the unique specimen of Epiperipatus edwardsii examined from French Guiana. Julián Monge-Nájera and Bernal MoreraBrenes whom donated specimens of Peripatus solozanoi and Epiperipatus biolleyi and Epiperipatus isthmicola. Dr Eduardo Florez, for providing specimens from Colombia. Beka Buckman, Brittany Damron and Denis Jacob provided help and comments. We also acknowledge partial support funding such as Labex CEBA (ANR-10-LABX-25-01) to collect the Epiperipatus edwardsii specimen. This work was partially supported by FAPESP 2011/20211-0, 2012/02969-6 and 2014/20557-2 to C.S. and R.P.R. authors. 


\section{REFERENCES}

Aguinaldo, A. M. A., Turbeville, J. M., Linford, L. S., Rivera, M. C, Garey, J. R., Raff, R. A. \& Lake, J. A. 1997. Evidence for a clade of nematodes, arthropods and other moulting animals. Nature, 387: 489-493.

Borges, S. H. \& Silva, J. M. C. 2012. A new area of endemism for amazonian birds in the rio Negro basin. The Wilson Journal of Ornithology, 124 (1):15-23.

Bouvier, E. L 1899. Sur les caractères externes des Péripates. Proceedings of the International Congress of Zoology, 4:269-271.

Bouvier, E. L. 1905. Monographie des Onychophores. Annales des Sciences Naturelles, Zoologie, (Série 9) 2: 1-383

Briscoe, D. A. \& Tait, N. N. 1995. Allozyme evidence for extensive and ancient radiations in Australia Onychophora. Zoological Journal of the Linnean Society, 114: 91-102.

Brito, S. V., Pereira, J. C., Ferreira, F. S., Vasconcellos, A. \& Almeida, W. O. 2010. Epiperipatus cratensis sp. nov. (Onychophora: Peripatidae) from northeastern Brazil. Neotropical Biology and Conservation, 5: 47-52.

Chagas-Junior, A. \& Costa, C. S. 2014. Macroperipatus ohausi: redescription and taxonomic notes on its status (Onychophora: Peripatidae). Revista de Biología Tropical, 62: 977-985.

Clark, A. H. 1913. Revision of the American species of Peripatus. Proceedings of the Biological Society Washington, 26: 15-19.

Daniels, S. R., Picker, M. D., Cowlin, R. M \& Hamer, M .L. 2009. Unravelling evolutionary lineages among South African velvet worms (Onychophora: Peripatopsis) provides evidence for widespread cryptic speciation. Biological Journal of the Linnean Society, 97: 200-216. doi: 10.1111/j.1095-8312.2009.01205.x.

Dikow, T. 2009. A phylogenetic hypothesis for Asilidae based on a total evidence analysis of morphological and DNA sequence data (Insecta: Diptera: Brachycera: Asiloidea). Organisms, Diversity \& Evolution, 9: 165-188.

Ewing, B. \& Green, P. 1998. Base-calling of Automated Sequencer Traces using Phred II. Error Probabilities. Genome Research, 8: 186-194.

Ewing, B., Hillier, L., Wendl, M. C. \& Green, P. 1998. Base-calling of Automated Sequencer Traces using Phred I. Accuracy Assessment. Genome Research, 8: 175-185. 
Frost, D. R., Grant, T., Faivovich, J., Bain, R. H., Haas, A., Haddad, C. F. B., Sá, R. O. de, Channing, A., Wilkinson, M., Donnellan, S. C., Raxworthy, C. J., Campbell, J. A., Blotto, B. L., Moler, P., Drewes, R. C., Nussbaum, R. A., Lynch, J. D., Green, D. M. \& Wheeler, W .C. 2006. The Amphibian Tree of Life. Bulletin of the American Museum of Natural History, 297:1-291.

Giribet, G. 2001. Exploring the Behavior of POY, a Program for Direct Optimization of Molecular Data. Cladistics, 17: S60-S70.

Giribet, G. \& Edgecombe, G. D. 2013. Stable phylogenetic patterns in scutigeromorph centipedes (Myriapoda: Chilopoda: Scutigeromorpha): dating the diversification of an ancient lineage of terrestrial arthropods. Invertebrate Systematics, 27:485-501.

Goloboff, P., Farris, J. \& Nixon, K. 2003. TNT: Tree analysis using newtechnology. Program and documentation. Available at: http://www.zmuc.dk/public/phylogeny/tnt.

Gordon, D., Abajian, C. \& Green, P. 1998. Consed: a graphical tool for sequence finishing. Genome Research, 8: 195-202.

Gordon, D., Desmarais, C. \& Green, P. 2001. Automated finishing with autofinish. Gemome Research, 11: 614-625.

Hall, T. A. 1999. BioEdit: a user-friendly biological sequence alignment editor and analysis program for Windows 95/98/NT. Nucleic Acids. Symposium Series, 41: 95-98.

Hall, J. P. W. \& Harvey, D. J. 2002. The phylogeography of Amazonia revisited: new evidence from riodinid butterflies. Evolution, 56:1489-1497.

Katoh, K. \& Standley, D.M. 2013. MAFFT multiple sequence alignment software version 7: improvements in performance and usability. Molecular Biology and Evolution, 30(4): 772-780.

Kluge, A.G. 1989. A Concern for Evidence and a Phylogenetic Hypothesis of Relationships Among Epicrates (Boidae, Serpentes). Systematic Zoology, 38(1): 7-25.

Kluge, A.G. 2004. On total evidence: for the record. Cladistics, 20: 205-207.

Lacorte, G. A., Oliveira, I. S. \& Fonseca C. G. 2011. Population structure and demographic inferences concerning the endangered onychophoran species Epiperipatus acacioi (Onychophora: Peripatidae). Zootaxa, 65: 57-65.

Machado D. J. 2015. YBYRÁ facilitates comparison of large phylogenetic trees. BMC Bioinformatics, 16: 204.

Maddison, W. P. \& Maddison, D.R. 2015. Mesquite: a modular system for evolutionary analysis. 
Version $3.02 \mathrm{http}: / /$ mesquiteproject.org.

Mallatt, J. \& Giribet, G. 2006. Further use of nearly complete 28S and 18S rRNA genes to classify Ecdysozoa: 37 more arthropods and a kinorhynch. Molecular Phylogenetics and Evolution, 40, $772-794$.

Morrone, J. J. 2014. Biogeographical regionalisation of the neotropical region. Zootaxa, 3782(1): 1110.

Miller, M. A., Pfeiffer, W. \& Schwartz, T. 2010. "Creating the CIPRES Science Gateway for inference of large phylogenetic trees" in Proceedings of the Gateway Computing Environments Workshop (GCE), 14 Nov. 2010, New Orleans, LA pp 1-8.

Murienne, J., Daniels, S. R, Buckley, T. R., Mayer, G. \& Giribet, G. 2014. A living fossil tale of Pangaean biogeography. Proceedings of the Royal Society B: Biological Sciences, 281: 20132648. http://dx.doi.org/10.1098/rspb.2013.2648.

O’Leary, M.A. \& Kaufman, S.G. 2011. MorphoBank: Phylophenomics in the "cloud". Cladistics 27: $1-9$.

O’Leary, M. A. \& Kaufman, S. G. 2012. MorphoBank 3.0: Web application for morphological phylogenetics and taxonomy. http://www.morphobank.org.

Oliveira, I. S. \& Wieloch, A. H. 2005. Macroperipatus machadoi sp. n. (Onychophora: Peripatidae) da floresta atlântica de Minas Gerais, Brasil. Lundiana, 6 (supplement): 61-66.

Oliveira, I. S., Wieloch, A. H. \& Mayer, G. 2010. Revised taxonomy and redescription of two species of the Peripatidae (Onychophora) from Brazil: a step towards consistent terminology of morphological characters. Zootaxa, 2493: 16-34.

Oliveira, I. S., Lacorte, G. A., Fonseca, C. G., Wieloch, A. H. \& Mayer, G. 2011. Cryptic Speciation in Brazilian Epiperipatus (Onychophora: Peripatidae) Reveals an Underestimated Diversity among the Peripatid Velvet Worms. PLoS ONE, 6: 1-13.

Oliveira, I. S., Read, V. M. St. J. \& Mayer, G. 2012a. A world checklist of Onychophora (velvet worms), with notes on nomenclature and status of names. ZooKeys, 211: 1-70.

Oliveira, I. S., Franke, F.A., Hering, L., Schaffer, S. \& Rowell, D. M. 2012b. Unexplored Character Diversity in Onychophora (Velvet Worms): A Comparative Study of Three Peripatid Species. PLoS ONE, 7(12): e51220.

Oliveira, I. S, Tait, N. N., Strübing, I. \& Mayer, G. 2013. The role of ventral and preventral organs as 
attachment sites for segmental limb muscles in Onychophora. Frontiers in Zoology, 2013 10:73.

Oliveira, I. S., Lacorte, G. A., Weck-Heimann, A., Cordeiro, L. M., Wieloch, A. H. \& Mayer, G. 2015. A new and critically endangered species and genus of Onychophora (Peripatidae) from the Brazilian savannah - a vulnerable biodiversity hotspot. Systematics and Biodiversity, 13: 211233.

Padial, J. M., Grant, T. \& Frost, D. 2014. Molecular systematics of terraranas (Anura: Brachycephaloidea) with an assessment of the effects of alignment and optimality criteria. Zootaxa, 3825(1): 1-132.

Peck, S. B. 1975. A review of the New World Onychophora with the description of a new cavernicolous genus and species from Jamaica. Psyche, 82: 341-358.

Read, V. M. S. J. 1988a. The application of scanning electron microscopy to the systematics of the neotropical Peripatidae (Onychophora). Zoological Journal of the Linnean Society, 93: 187223.

Read, V. M. S. J. 1988b. The Onychophora of Trinidad, Tobago and the Lesser Antilles. Zoological Journal of the Linnean Society, 93: 225-257.

Reid, A. 1996. Review of the Peripatopsidae (Onychophora) in Australia, with comments on peripatopsid relationships. Invertebrate Taxonomy, 10(4): 663-936.

Rindal, E. \& Brower, A. V. Z. 2011. Do model-based phylogenetic analyses perform better than parsimony? A test with empirical data. Cladistics, 27(3): 1-4.

Ruhberg, H. 1985. Die Peripatopsidae (Onychophora). Systematik, Ökologie, Chorologie und phylogenetische Aspekte. Zoologica (Stuttgart), 137: 1-184.

Sampaio-Costa, C., Chagas-Junior, A., Baptista, R. L. C. 2009. Brazilian species of Onychophora with notes on their taxonomy and distribution. Zoologia, 26(3): 553-561.

Silva, J. M. C., Rylands, A. B. \& Fonseca, G. A. B. 2005. The Fate of the Amazonian Areas of Endemism. Conservation Biology, 19(3): 689-694.

Stamatakis, A. 2014. RAxML Version 8: A tool for Phylogenetic Analysis and Post-Analysis of Large Phylogenies.

Bioinformatics, 10.1093/bioinformatics/btu033 http://bioinformatics.oxfordjournals.org/content/early/2014/01/21/bioinformatics.btu033.abstr act.

Tait, N. N. \& Norman, J. M. 2001. Novel mating behaviour in Florelliceps stutchburyae gen. nov., 
sp. nov. (Onychophora: Peripatopsidae) from Australia. The Zoological Society of London, 253: 301-308.

Vaidya, G., Lohman, D. J., \& Meier, R. 2011. SequenceMatrix: concatenation software for the fast assembly of multi-gene datasets with character set and codon information. Cladistics, 27, 171180. doi:10.1111/j.1096-0031.2010.00329.x.

Varón, A., L. S. Vinh, W. C. Wheeler. 2010. POY version 4: phylogenetic analysis using dynamic homologies. Cladistics, 26: 72-85.

Wheeler, W. C., Aagesen, L., Arango, C. P., Faivovich, J., Grant, T., D'Haese, C., Janies, D., Smith, W.L., Varón, A., \& Giribet, G. 2006. Dynamic Homology and Phylogenetic Systematics: A Unified Approach Using POY. New York: American Museum of Natural History, New York. 365 pp.

Wheeler, W. C. 2012. Comparison of Optimality Criteria, in Systematics: A Course of Lectures. John Wiley \& Sons, Ltd, Chichester, UK. doi: 10.1002/9781118301081.ch5. 


\section{Supplementary Information}

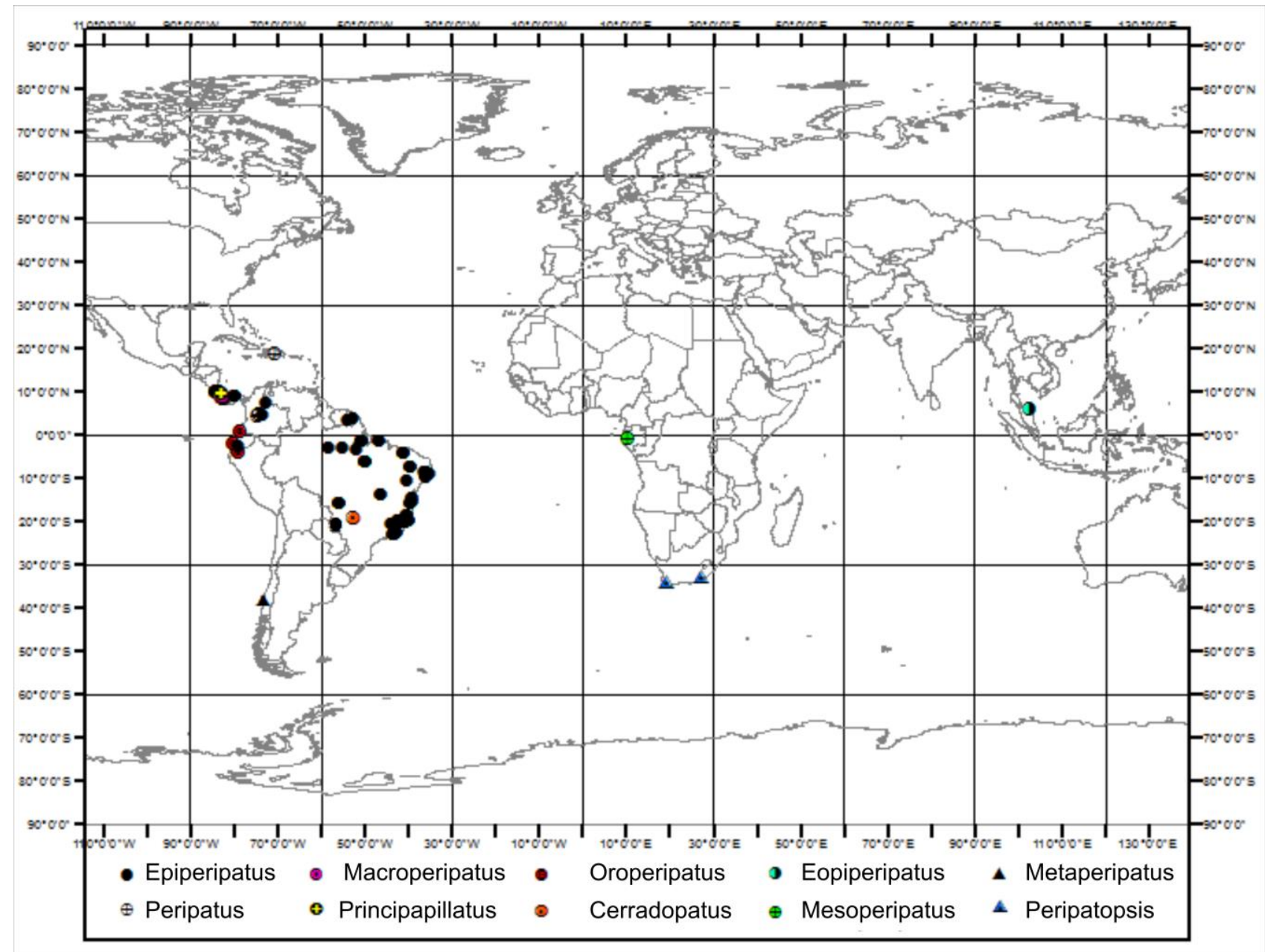

Figure S.1. Overview map highlighting the localities where the specimens were obtained. For Peripatidae, Epiperipatus are indicated by black dots, while the others dots show the localities of Oroperipatus species; C. sucuriuensis Oliveira et al., 2015; E. cf. horsti; M. tholloni (Bouvier, 1898) Peripatus basilensis Brues, 1935; P. hitoyiensis Oliveira et al., 2012. For Peripatopsidae, the dots indicate M. inae Mayer 2005; P. moleseyi (Wood-Mason, 1879) and P. lawrencei McDonald, Ruhberg \& Daniels, 2012. Note the Epiperipatus distribution in neotropic. 

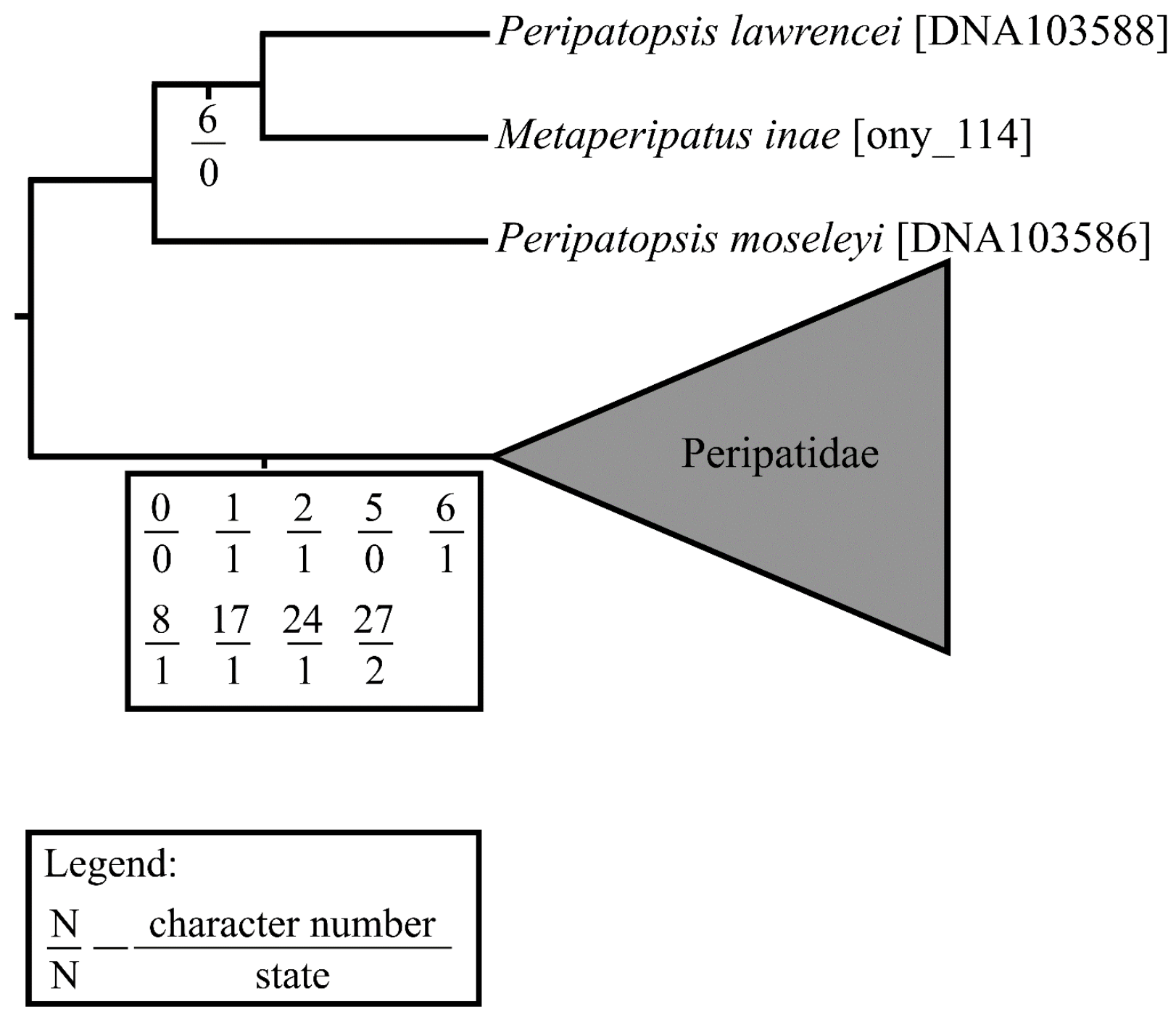

Figure S.2. Consensus tree of 100 equally parsimonious trees (score 91). The topology was obtained through TNT analyses for seventy-four terminals. The characters and its states can be checked in the List of Characters (Supplementary Information) and the morphological matrix Table S.2. 


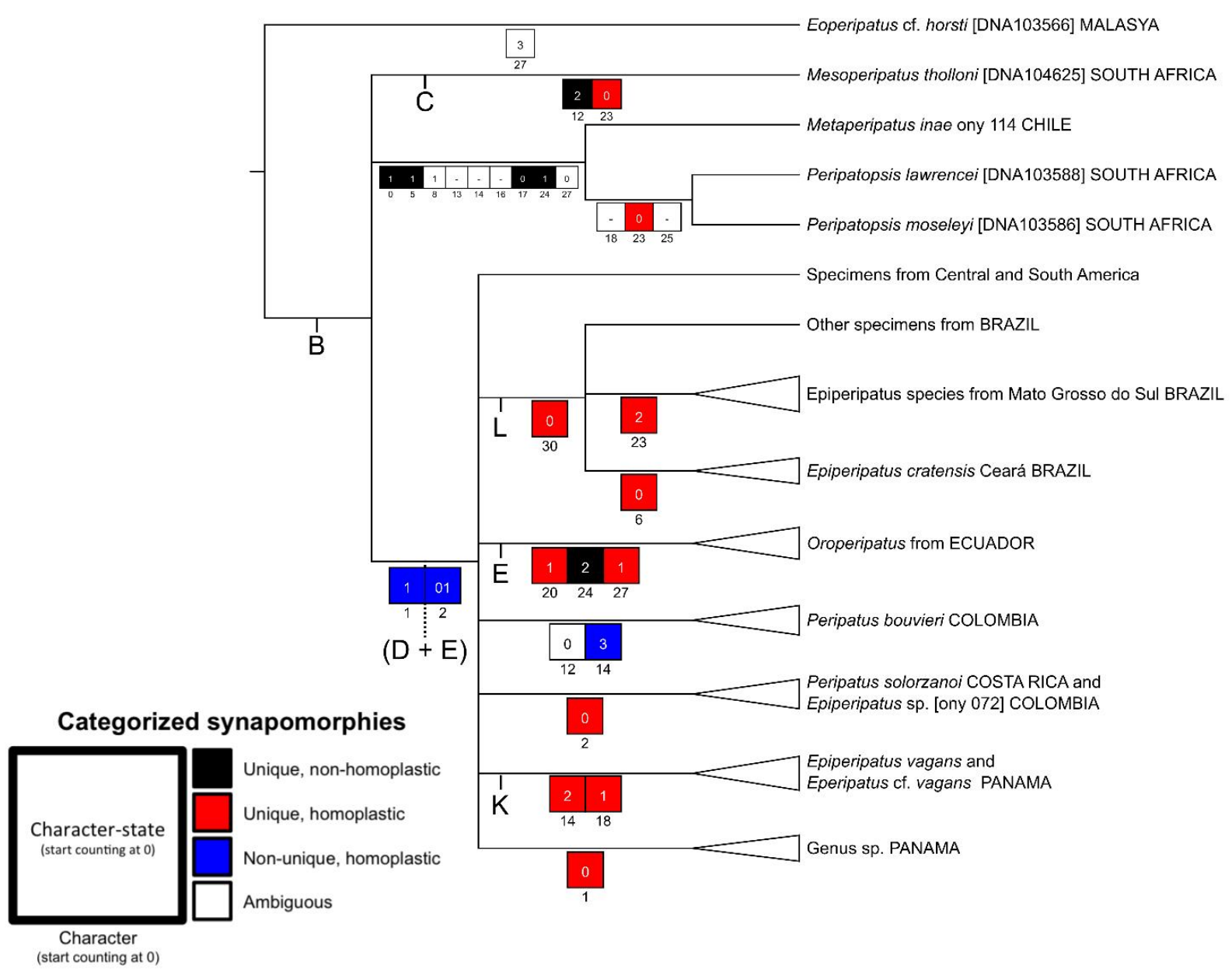

Figure S.3. Morphology mapping through YBYRÁ. The topology resulted from the total evidence analysis under POY. The collapsed nodes are non-supported nodes through morphological characters. The characters and its states can be checked in the List of Characters (Supplementary Information). 
Table S.1. Specimens examined and markers obtained (1/5).

\begin{tabular}{|c|c|c|c|c|c|c|c|}
\hline Morphotype & ID Number & Voucher & Locality & COI & $12 \mathrm{~S}$ & $16 \mathrm{~S}$ & 18S \\
\hline Epiperipatus n. sp. [sp16] & MNRJ 0045 & ony_002 & Brazil, Bahia state, Camacan municipality & $\cdot \bullet$ & - & - & $\bullet$ \\
\hline Epiperipatus [sp11] & MNRJ 0046 & ony_003 & Brazil, Espírito Santo state, Santa Teresa municipality & - & $\circ$ & - & $\circ$ \\
\hline Oroperipatus corradoi & MNRJ 0071 & ony_005 & Ecuador, Lora, Zamora huayco & - & - & - & - \\
\hline Oroperipatus cf. corradoi & MNRJ 0073 & ony_006 & Ecuador, Guayas, Guayaquil & - & - & - & - \\
\hline Epiperipatus [sp7] & MNRJ 0052 & ony_007 & Brazil, Alagoas state, Satuba municipality & - & - & - & $\circ$ \\
\hline Epiperipatus machadoi & MNRJ 0043 & ony_008 & Brazil, Minas Gerais state, Caratinga municipality & - & - & - & $\circ$ \\
\hline Epiperipatus ohausi & MNRJ 0058 & ony_010 & Brazil, Rio de Janeiro state, Nova Iguaçu municipality & - & 0 & o & o \\
\hline Epiperipatus ohausi & MNRJ 0056 & ony_011 & Brazil, Rio de Janeiro state, Nova Iguaçu municipality & - & - & - & - \\
\hline Epiperipatus [sp5] & MNRJ 0059 & ony_012 & Brazil, Rio de Janeiro state, Guapimirim municipality & - & 0 & - & $\circ$ \\
\hline Oroperipatus sp. & MNRJ 0072 & ony_013 & Ecuador, Chimborazo, Sibambe & - & - & - & - \\
\hline Oroperipatus sp. & MNRJ 0069 & ony_014 & Ecuador, Esmeraldas, Chuchuvi & - & - & - & - \\
\hline Epiperipatus [sp8] & MNRJ 0055 & ony_015 & Brazil, Pernambuco state, Tamandaré municipality & - & - & - & - \\
\hline Epiperipatus [sp12] & MNRJ 0065 & ony_017 & Brazil, Espírito Santo state, Pinheiros municipality & - & - & - & $\circ$ \\
\hline Epiperipatus $\mathrm{n}$. sp. & ONY-19 & ony_020 & Brazil, Mato Grosso do Sul state, Bodoquena municipality & - & - & - & - \\
\hline Epiperipatus n. sp. [troglobius] & ONY-10 & ony_022 & Brazil, Mato Grosso do Sul state, Bodoquena municipality & - & - & - & $\circ$ \\
\hline Epiperipatus paurognostus & UFMG & ony_024 & Brazil, Minas Gerais state, Piedade de Caratinga municipality & - & - & - & - \\
\hline Epiperipatus acacioi & UFMG & ony_025 & Brazil, Minas Gerais state, Ouro Preto municipality, Tripuí & - & - & - & $\circ$ \\
\hline Epiperipatus acacioi & UFMG & ony_026 & $\begin{array}{l}\text { Brazil, Minas Gerais state, Ouro Preto municipality, Tripuí and } \\
\text { Itacolomi }\end{array}$ & $\bullet$ & $\circ$ & $\circ$ & 。 \\
\hline Epiperipatus [sp11] & MNRJ 0042 & ony_027A & Brazil, Espírito Santo state, Santa Teresa municipality & - & - & - & $\circ$ \\
\hline Epiperipatus [sp11] & MNRJ 0042 & ony_027B & Brazil, Espírito Santo state, Santa Teresa municipality & - & - & - & $\circ$ \\
\hline Epiperipatus [sp11] & MNRJ 0042 & ony_027C & Brazil, Espírito Santo state, Santa Teresa municipality & - & - & - & $\circ$ \\
\hline Epiperipatus [sp11] & MNRJ 0015 & ony_028 & Brazil, Espírito Santo state, Santa Teresa municipality & - & $\circ$ & $\circ$ & $\circ$ \\
\hline Epiperipatus [sp13] & MNRJ 0020 & ony_029 & Brazil, Espírito Santo state, Linhares municipality & $\circ$ & - & - & $\circ$ \\
\hline Epiperipatus [sp13] & MNRJ 0018 & ony_030A & Brazil, Espírito Santo state, Linhares municipality & $\circ$ & - & - & $\circ$ \\
\hline Epiperipatus [sp13] & MNRJ 0018 & ony_030B & Brazil, Espírito Santo state, Linhares municipality & 0 & - & $\circ$ & $\circ$ \\
\hline Epiperipatus [sp14] & MNRJ 0016 & ony_032 & Brazil, Espírito Santo state, Cariacica municipality & $\circ$ & $\circ$ & - & $\circ$ \\
\hline Epiperipatus [sp11] & MNRJ 0034 & ony_034 & Brazil, Espírito Santo state, Santa Teresa municipality & $\bullet$ & $\bullet$ & - & $\circ$ \\
\hline Epiperipatus [sp6] & MNRJ 0088 & ony_036 & Brazil, Rio de Janeiro state, Cachoeiras de Macacu municipality & $\bullet$ & • & $\bullet$ & • \\
\hline Epiperipatus [sp6] & MNRJ 0087 & ony_037 & Brazil, Rio de Janeiro state, Cachoeiras de Macacu municipality & $\bullet$ & $\circ$ & $\bullet$ & $\circ$ \\
\hline Epiperipatus acacioi & MNRJ 0044 & ony_038 & Brazil, Minas Gerais state, Ouro Preto municipality, Tripuí & - & - & - & $\circ$ \\
\hline
\end{tabular}

Legend: • fragments sequenced; ○ fragments not sequenced. Names of the institutions: MNRJ - Museu Nacional do Rio de Janeiro; MZUSP Museu de Zoologia da Universidade de São Paulo; UFMG - Universidade Federal de Minas Gerais; Ony - Universidade Federal do Mato Grosso do Sul; UFPB - Universidade Federal da Paraíba; CHNUFPI - Universidade Federal do Piauí; ICN-ONY - Universidade Nacional de Colombia; UNACHI - Universidade Autonoma de Chiriquí; MCZ, FG - Museum of Comparative Zoology; GB - Genbank. 
Table S.1. (Continued, 2/5)

\begin{tabular}{|c|c|c|c|c|c|c|c|}
\hline Morphotype & ID Number & Voucher & $\begin{array}{ll}\text { Locality } \\
\end{array}$ & COI & $12 \mathrm{~S}$ & 16S & 18S \\
\hline Epiperipatus n. sp. & MZUSP 0009 & ony_039 & $\begin{array}{l}\text { Brazil, Alagoas state, Murici municipality (Federal University of } \\
\text { Alagoas state) }\end{array}$ & • & - & - & $\circ$ \\
\hline Epiperipatus n. sp. [sp17] & MZUSP 0010 & ony_040 & Brazil, Alagoas state, Murici municipality & - & - & - & $\circ$ \\
\hline Epiperipatus n. sp. [sp2] & MZUSP 0011 & ony_041 & Brazil, Alagoas state, Murici municipality & - & - & - & $\circ$ \\
\hline Epiperipatus n. sp. [sp17] & MNRJ 0053 & ony_043 & Brazil, Alagoas state, Murici municipality & - & - & - & - \\
\hline Epiperipatus [sp2] & MNRJ 0053 & ony_044 & Brazil, Alagoas state, Murici municipality & - & - & - & - \\
\hline Epiperipatus [sp1] & MNRJ 0053 & ony_045 & Brazil, Alagoas state, Murici municipality & - & - & - & - \\
\hline Epiperipatus [sp1] & MNRJ 0053 & ony_046 & Brazil, Alagoas state, Murici municipality & - & - & - & - \\
\hline Epiperipatus [sp2] & MNRJ 0053 & ony_047 & Brazil, Alagoas state, Murici municipality & - & - & - & $\circ$ \\
\hline Epiperipatus [sp12] & MNRJ 0023 & ony_048 & Brazil, Espírito Santo state, Pinheiros municipality & - & - & - & o \\
\hline Epiperipatus [sp12] & MNRJ 0026 & ony_049 & Brazil, Espríito Santo state, Pinheiros municipality & $\circ$ & • & - & $\circ$ \\
\hline Epiperipatus [sp12] & MNRJ 0027 & ony_050 & Brazil, Espírito Santo state, Pinheiros municipality & - & $\circ$ & - & o \\
\hline Epiperipatus n. sp. [sp16] & MZUSP 0017 & ony_051 & Brazil, Bahia state, Camacan municipality & - & - & - & $\circ$ \\
\hline Epiperipatus n. sp. & MNRJ 0083 & ony_052 & Brazil, Pará state, Bragança municipality & $\circ$ & $\circ$ & - & $\circ$ \\
\hline Epiperipatus n. sp. & MNRJ 0086 & ony_053 & Brazil, Pará state, Bragança municipality & - & $\circ$ & - & $\circ$ \\
\hline Epiperipatus acacioi & MNRJ 0044 & ony_054 & Brazil, Minas Gerais state, Ouro Preto municipality, Tripuí & - & - & - & - \\
\hline Epiperipatus [sp9] & MNRJ 0054 & ony_055 & Brazil, Pernambuco state, Caruaru municipality & - & - & - & - \\
\hline Epiperipatus [sp9] & MNRJ 0054 & ony_056 & Brazil, Pernambuco state, Caruaru municipality & - & - & - & - \\
\hline Epiperipatus [sp9] & MNRJ 0054 & ony_057 & Brazil, Pernambuco state, Caruaru municipality & • & • & • & - \\
\hline Epiperipatus sp. & MNRJ 0091 & ony_058 & Guiana Francesa, R. S. of Maripasoula & - & o & $\circ$ & o \\
\hline Epiperipatus edwardsii & GF180312HC003-06 & ony_059 & Guiana Francesa, Nouragues Field Station & - & - & - & - \\
\hline Epiperipatus biolleyi & MZUSP 0012 & ony_060A & Costa Rica, San José, Cascajal de Coronado & - & - & - & - \\
\hline Epiperipatus biolleyi & MZUSP 0012 & ony_060B & Costa Rica, San José, Cascajal de Coronado & $\circ$ & $\circ$ & - & • \\
\hline Epiperipatus isthmicola & MNRJ 0092 & ony_061 & Costa Rica, San José, Barrio Vasconia & - & - & - & $\circ$ \\
\hline Epiperipatus sp. & MNRJ 0089 & ony_062A & Costa Rica, Heredia & • & • & • & o \\
\hline Epiperipatus sp. & MNRJ 0089 & ony_062B & Costa Rica, Heredia & o & - & - & $\circ$ \\
\hline Peripatus solorzanoi & MZUSP 0013 & ony_063 & Costa Rica, Limón, Guayacán de Siquirres & - & - & - & - \\
\hline Peripatus solorzanoi & MNRJ 0090 & ony_064 & Costa Rica, Cartago, Guayacán de Turrialba & - & $\circ$ & $\circ$ & ० \\
\hline Epiperipatus [sp6] & MNRJ 0093 & ony_065 & Brazil, Rio de Janeiro state, Cachoeiras de Macacu municipality & • & • & • & $\circ$ \\
\hline Epiperipatus sp. & ONY-30 & ony_066 & Brazil, Mato Grosso do Sul, Bodoquena municipality & - & - & - & - \\
\hline Epiperipatus sp. & ONY-32 & ony_067 & Brazil, Mato Grosso do Sul, Bodoquena municipality & - & - & - & - \\
\hline
\end{tabular}

Legend: • fragments sequenced; ○ fragments not sequenced. Names of the institutions: MNRJ - Museu Nacional do Rio de Janeiro; MZUSP Museu de Zoologia da Universidade de São Paulo; UFMG - Universidade Federal de Minas Gerais; Ony - Universidade Federal do Mato Grosso do Sul; UFPB - Universidade Federal da Paraíba; CHNUFPI - Universidade Federal do Piauí; ICN-ONY - Universidade Nacional de Colombia; UNACHI - Universidade Autonoma de Chiriquí; MCZ, FG - Museum of Comparative Zoology; GB - Genbank. 
Table S.1. (Continued, 3/5)

\begin{tabular}{|c|c|c|c|c|c|c|c|}
\hline Morphotype & ID Number & Voucher & Locality & COI & $12 \mathrm{~S}$ & $\mathbf{1 6 S}$ & $18 \mathrm{~S}$ \\
\hline Epiperipatus sp. & ONY-31 & ony_068 & Brazil, Mato Grosso do Sul state, Bodoquena municipality & $\cdot$ & - & - & - \\
\hline Epiperipatus sp. & ONY-16 & ony_069 & Brazil, Mato Grosso do Sul state, Bodoquena municipality & $\circ$ & - & - & $\circ$ \\
\hline Epiperipatus n. sp. & MZUSP 0018 & ony_071 & Brazil, Pará state, Altamira & - & - & - & - \\
\hline Epiperipatus sp. & ICN-ONY-15 & ony_072 & Colombia, Boyacá, Santa Maria & - & - & $\circ$ & $\circ$ \\
\hline Peripatus bouvieri & ICN-ONY-27 & ony_074 & Colombia, Cundinamarca, San Antonio del Tequendama & - & - & - & - \\
\hline Peripatus bouvieri & ICN ONY-28 & ony_075 & Colombia, Cundinamarca, San Antonio del Tequendama & - & - & - & - \\
\hline Peripatus bouvieri & ICN ONY-13 & ony_076 & Colombia, Cundinamarca, Soacha & - & - & - & - \\
\hline Epiperipatus sp. & MZUSP 0021 & ony_077 & Brazil, Pará state, Parauapebas municipality & - & - & - & - \\
\hline Epiperipatus n. sp. [sp10] & MZUSP 0022 & ony_078 & Brazil, Pará state, Breves municipality & - & - & - & - \\
\hline Epiperipatus n. sp. [sp10] & MZUSP 0023 & ony_079 & Brazil, Pará state, Breves municipality & - & - & - & - \\
\hline Epiperipatus n. sp. [sp10] & MZUSP 0024 & ony_080 & Brazil, Pará state, Breves municipality & - & - & - & - \\
\hline Epiperipatus n. sp. [sp10] & MZUSP 0025 & ony_081 & Brazil, Pará state, Breves municipality & - & - & $\circ$ & - \\
\hline Epiperipatus $\mathrm{n}$. sp. [sp10] & MZUSP 0026 & ony_082 & Brazil, Pará state, Breves municipality & - & - & - & - \\
\hline Epiperipatus n. sp. [sp10] & MZUSP 0027 & ony_083 & Brazil, Pará state, Breves municipality & - & - & - & - \\
\hline Epiperipatus [sp4] & MZUSP 0028 & ony_084 & Brazil, Pará state, Bragança municipality & - & - & - & - \\
\hline Epiperipatus sp. & MZUSP 0001 & ony_085 & Brazil, Pará state, Carajás municipality & $\circ$ & - & $\circ$ & $\circ$ \\
\hline Epiperipatus sp. & MZUSP 0002 & ony_086 & Brazil, Pará state, Carajás municipality & - & - & - & $\circ$ \\
\hline Epiperipatus sp. & MZUSP 0003 & ony_087 & Brazil, Pará state, Carajás municipality & - & - & - & $\circ$ \\
\hline Epiperipatus sp. & MZUSP 0007 & ony_091 & Brazil, Pará state, Carajás municipality & - & 0 & - & 0 \\
\hline Epiperipatus sp. & MZUSP 0008 & ony_092 & Brazil, Pará state, Carajás municipality & - & $\circ$ & $\circ$ & $\circ$ \\
\hline Epiperipatus sp. & MZUSP 0015 & ony_093 & Brazil, Mina Gerais state, Jequitinhonha municipality & $\bullet$ & $\bullet$ & $\bullet$ & $\circ$ \\
\hline unidentified & MZUSP 0019 & ony_094 & Brazil, Goias state, São Domingos municipality (Angelica Cave) & - & $\bullet$ & $\bullet$ & $\bullet$ \\
\hline unidentified & MZUSP 0020 & ony_095 & Brazil, Goias state, São Domingos municipality (Suspirão Cave) & - & $\circ$ & - & $\circ$ \\
\hline Epiperipatus sp. & MZUSP 0029 & ony_096 & Brazil, Bahia state, Campo Formoso municipality & • & - & • & - \\
\hline Epiperipatus diadenoproctus & UFMG 0155 & ony_097 & Brazil, Minas Gerais state, Simonésia municipality & - & - & - & $\circ$ \\
\hline Epiperipatus diadenoproctus & UFMG 0113 & ony_098 & Brazil, Minas Gerais state, Simonésia municipality & - & • & - & $\circ$ \\
\hline Epiperipatus diadenoproctus & UFMG 0110 & ony_099 & Brazil, Minas Gerais state, Simonésia municipality & $\circ$ & - & - & $\circ$ \\
\hline Epiperipatus paurognostus & UFMG 0184 & ony_100 & $\begin{array}{l}\text { Brazil, Minas Gerais state, Piedade de Caratinga municipality } \\
\text { (Sítio Gegê) }\end{array}$ & $\circ$ & $\bullet$ & $\bullet$ & $\circ$ \\
\hline Epiperipatus paurognostus & UFMG 0060 & ony_101 & Brazil, Minas Gerais state, Piedade de Caratinga municipality & - & - & - & 0 \\
\hline Epiperipatus paurognostus & UFMG 0181 & ony_102 & Brazil, Minas Gerais state, Piedade de Caratinga municipality & - & - & - & $\circ$ \\
\hline
\end{tabular}

Legend: • fragments sequenced; ○ fragments not sequenced. Names of the institutions: MNRJ - Museu Nacional do Rio de Janeiro; MZUSP Museu de Zoologia da Universidade de São Paulo; UFMG - Universidade Federal de Minas Gerais; Ony - Universidade Federal do Mato Grosso do Sul; UFPB - Universidade Federal da Paraíba; CHNUFPI - Universidade Federal do Piauí; ICN-ONY - Universidade Nacional de Colombia; UNACHI - Universidade Autonoma de Chiriquí; MCZ, FG - Museum of Comparative Zoology; GB - Genbank. 
Table S.1. (Continued, 4/5)

\begin{tabular}{|c|c|c|c|c|c|c|c|}
\hline Morphotype & ID Number & Voucher & Locality & COI & $12 \mathrm{~S}$ & $16 \mathrm{~S}$ & $18 \mathrm{~S}$ \\
\hline Epiperipatus adenocryptus & UFMG 0089 & ony_103 & Brazil, Minas Gerais state, Santa Bárbara do Leste municipality & $\circ$ & $\cdot \bullet$ & 0 & 0 \\
\hline Epiperipatus adenocryptus & UFMG 0072 & ony_104 & Brazil, Minas Gerais state, Santa Bárbara do Leste municipality & $\circ$ & - & - & o \\
\hline Epiperipatus adenocryptus & UFMG 0083 & ony_105 & Brazil, Minas Gerais state, Santa Bárbara do Leste municipality & o & - & - & o \\
\hline Epiperipatus paurognostus & MZUSP 0033 & ony_106 & Brazil, Minas Gerais state, Piedade de Caratinga municipality & - & - & - & - \\
\hline Epiperipatus n. sp. [sp17] & MNRJ 0053 & ony_107 & Brazil, Alagoas state, Murici municipality & - & - & - & - \\
\hline Epiperipatus n. sp. [sp2] & MNRJ 0053 & ony_108 & Brazil, Alagoas state, Murici municipality & - & - & - & - \\
\hline Epiperipatus $\mathrm{n}$. sp. [sp1] & MNRJ 0053 & ony_109 & Brazil, Alagoas state, Murici municipality & - & - & - & $\circ$ \\
\hline Epiperipatus $\mathrm{n}$. sp. & MZUSP 0073 & ony_112 & Colombia, Santander, Pamplona & - & - & - & - \\
\hline Epiperipatus sp. & MZUSP 0072 & ony_113 & Brazil, Amazonas state, Silves municipality & - & - & $\circ$ & - \\
\hline Metaperipatus inae & MZUSP 0074 & ony_114 & Chile, Araucania & - & - & - & $\circ$ \\
\hline Epiperipatus cratensis & CHNUFPI (ONY) 0001 & ony_115 & Brazil, Ceará state, Crato & $\circ$ & - & - & - \\
\hline Epiperipatus n. sp. & UFPB PG 0005 & ony_117 & Brazil, Pernambuco state, Caruaru municipality & $\circ$ & - & - & $\circ$ \\
\hline Epiperipatus sp. & UFPB PG 0008 & ony_118 & Brazil, Alagoas state, Ibateguara municipality, Serra Grande & - & - & 0 & - \\
\hline unidentified & UFPB PG 0010 & ony_120 & Brazil, Pernambuco state, Bonito & $\circ$ & $\circ$ & - & $\circ$ \\
\hline Epiperipatus $\mathrm{n}$. sp. [white head 1] & MZUSP 0087 & ony_121 & Panama, Chiquiri, Jaramillo abajo, Boquete. & - & - & $\circ$ & - \\
\hline Epiperipatus n. sp. [white head 1] & MZUSP 0087 & ony_122 & Panama, Chiquiri, Jaramillo abajo, Boquete. & $\circ$ & - & - & $\circ$ \\
\hline Epiperipatus cf. vagans & MZUSP 0086 & ony_123 & Panama, Chiriqui, Jurutungo, near PN La Amistad & $\circ$ & - & - & $\circ$ \\
\hline Epiperipatus cf. vagans & MZUSP 0088 & ony_124 & Panama, Sendero El Charco, Soberanía & - & - & - & - \\
\hline Epiperipatus $\mathrm{n}$. sp. [white head 2] & UNACHI & ony_125 & Panama, Chiquiri, Barrio Bolivar, David & - & - & - & - \\
\hline Epiperipatus n. sp. [white head 2] & UNACHI & ony_126 & Panama, Chiquiri, Barrio Bolivar, David & - & - & - & $\circ$ \\
\hline Epiperipatus cratensis & MZUSP 0083 & ony_127 & Brazil, Ceará state, Crato & $\circ$ & - & - & - \\
\hline Epiperipatus cratensis & MZUSP 0084 & ony_128 & Brazil, Ceará state, Crato & $\circ$ & - & - & - \\
\hline Epiperipatus cratensis & MZUSP 0084 & ony_129 & Brazil, Ceará state, Crato & $\circ$ & - & - & - \\
\hline Epiperipatus [sp3] & MZUSP 0090 & ony_130 & Brazil, Ceará state, Ubajara municipality & - & - & - & - \\
\hline Epiperipatus [sp3] & MZUSP 0089 & ony_131 & Brazil, Ceará state, Ubajara municipality & - & - & - & - \\
\hline Epiperipatus [sp3] & MZUSP 0091 & ony_132 & Brazil, Ceará state, Ubajara municipality & - & - & - & - \\
\hline Epiperipatus [sp3] & MZUSP 0092 & ony_133 & Brazil, Ceará state, Ubajara municipality & - & - & - & $\circ$ \\
\hline unidentified & UFPB & ony_134 & Brazil, Pernambuco state, Bonito & $\circ$ & - & $\circ$ & • \\
\hline unidentified & MZUSP 0095 & ony_135 & Brazil, Pará state, Parauapebas municipality & $\circ$ & - & $\circ$ & - \\
\hline unidentified & MZUSP 0096 & ony_136 & Brazil, Pará state, Parauapebas municipality & $\circ$ & - & $\circ$ & - \\
\hline
\end{tabular}

Legend: • fragments sequenced; ○ fragments not sequenced. Names of the institutions: MNRJ - Museu Nacional do Rio de Janeiro; MZUSP Museu de Zoologia da Universidade de São Paulo; UFMG - Universidade Federal de Minas Gerais; Ony - Universidade Federal do Mato Grosso do Sul; UFPB - Universidade Federal da Paraíba; CHNUFPI - Universidade Federal do Piauí; ICN-ONY - Universidade Nacional de Colombia; UNACHI - Universidade Autonoma de Chiriquí; MCZ, FG - Museum of Comparative Zoology; GB - Genbank. 
Table S.1. (Continued, 5/5)

\begin{tabular}{|c|c|c|c|c|c|c|c|}
\hline Morphotype & ID Number & Voucher & Locality & COI & $12 S$ & $16 \mathrm{~S}$ & $18 \mathrm{~S}$ \\
\hline unidentified & MZUSP 0097 & ony_137 & Brazil, Pará state, Parauapebas municipality & 0 & $\bullet$ & $\circ$ & - \\
\hline unidentified & MZUSP 0100 & ony_138 & Brazil, Minas Gerais state, Itabirito municipality & - & - & 0 & - \\
\hline Epiperipatus cf. vagans & MZUSP 0101 & ony_139 & Panama, Panama City & - & - & - & - \\
\hline unidentified & MZUSP 0102 & ony_140 & Panama, Chiquiri, Jaramillo abajo, Boquete. & - & - & - & - \\
\hline unidentified & MZUSP 0103 & ony_141 & Panama, Chiquiri, Jaramillo abajo, Boquete. & - & - & - & - \\
\hline Epiperipatus n. sp. [white head 1] & MZUSP 0104 & ony_142 & Panama, Chiquiri, Jaramillo abajo, Boquete. & $\bullet$ & $\bullet$ & $\circ$ & $\bullet$ \\
\hline unidentified & MZUSP 0106 & ony_143 & Panama, Chiquiri, Universidade Autonoma de Chiriqui & $\bullet$ & $\bullet$ & $\bullet$ & $\bullet$ \\
\hline unidentified & MZUSP 0107 & ony_144 & Panama, Chiquiri, Universidade Autonoma de Chiriqui & - & • & - & - \\
\hline unidentified & MZUSP 0108 & ony_145 & Panama, Chiquiri, Gualaca & $\bullet$ & $\bullet$ & - & $\bullet$ \\
\hline Epiperipatus n. sp. [white head 2] & MZUSP 0109 & ony_146 & Panama, Chiquiri, Barrio Bolivar, David & $\bullet$ & $\bullet$ & $\bullet$ & o \\
\hline unidentified & MZUSP 0110 & ony_147 & Panama, Chiquiri, Universidade Autonoma de Chiriqui & $\bullet$ & $\bullet$ & $\bullet$ & $\bullet$ \\
\hline Epiperipatus [sp15] & MZUSP 0111 & ony_148 & Panama, Chiquiri, Rio Sereno, Monte Lirio & $\bullet$ & $\bullet$ & $\bullet$ & $\bullet$ \\
\hline Epiperipatus [sp15] & MZUSP 0112 & ony_149 & Panama, Chiquiri, Rio Sereno, Santa Clara & $\bullet$ & $\bullet$ & $\bullet$ & $\bullet$ \\
\hline Epiperipatus vagans & MZUSP 0113 & ony_150 & Panamá, Panama City, Parque Nacional Soberanía & $\bullet$ & • & $\bullet$ & $\bullet$ \\
\hline Epiperipatus vagans & MZUSP 0114 & ony_151 & Panama, Panama City, Parque Nacional Soberanía & $\bullet$ & $\bullet$ & $\bullet$ & $\bullet$ \\
\hline Epiperipatus vagans & MZUSP 0115 & ony_152 & Panama, Panama City, Parque Nacional Soberanía & $\bullet$ & $\bullet$ & $\bullet$ & $\bullet$ \\
\hline Epiperipatus sp. & MNRJ 0100 & ony_153 & Brazil, Espírito Santo state, Santa Leopoldina & $\circ$ & - & - & - \\
\hline unidentified & MZUSP 0116 & ony_154 & Brazil, Bahia state, Camacan municipality & $\circ$ & - & - & • \\
\hline unidentified & MZUSP 0117 & ony_155 & Brazil, Bahia state, Uruçuca municipality & ० & $\bullet$ & $\bullet$ & $\bullet$ \\
\hline unidentified & MZUSP 0118 & ony_156 & Brazil, Bahia state, Uruçuca municipality & $\circ$ & $\bullet$ & $\bullet$ & $\bullet$ \\
\hline unidentified & MZUSP 0119 & ony_157 & Brazil, Bahia state, Una & $\circ$ & $\bullet$ & $\bullet$ & $\bullet$ \\
\hline unidentified & MZUSP 0120 & ony_158 & Brazil, Bahia state, Una & $\circ$ & $\bullet$ & $\bullet$ & $\bullet$ \\
\hline Epiperipatus sp. & UFMT & ony_159 & Brazil, Mato Grosso state, Chapada dos Guimarães & $\circ$ & $\bullet$ & $\bullet$ & $\bullet$ \\
\hline Epiperipatus sp. & UFMT & ony_160 & Brazil, Mato Grosso state, Chapada dos Guimarães & ○ & $\bullet$ & $\bullet$ & $\bullet$ \\
\hline Epiperipatus sp. & UFMT & ony_161 & Brazil, Mato Grosso state, Chapada dos Guimarães & $\circ$ & $\bullet$ & $\bullet$ & $\bullet$ \\
\hline Epiperipatus sp. & UFMT & ony_162 & Brazil, Mato Grosso state, Chapada dos Guimarães & $\circ$ & $\bullet$ & $\bullet$ & $\bullet$ \\
\hline Epiperipatus sp. & UFMT & ony_163 & Brazil, Mato Grosso state, Chapada dos Guimarães & $\circ$ & $\bullet$ & $\bullet$ & $\bullet$ \\
\hline Epiperipatus brasiliensis & MZUSP 0121 & ony_164 & Brazil, Santarém state, Terra Rica (km 67), FLONA do Tapajós & $\circ$ & $\bullet$ & $\bullet$ & $\bullet$ \\
\hline Eoperipatus cf. horsti & MCZ-IZ131341 & DNA103566 & Malaysia & $\bullet$ & $\bullet$ & $\bullet$ & $\bullet$ \\
\hline Peripatopsis lawrencei & MCZ-IZ131348 & DNA103588 & South Africa, Western Cape; Off Franschoek & $\bullet$ & $\bullet$ & $\bullet$ & $\bullet$ \\
\hline Peripatopsis moseleyi & MCZ-IZ131346 & DNA103586 & South Africa, Eastern Cape; Keiskammahoek & $\bullet$ & $\bullet$ & $\bullet$ & $\bullet$ \\
\hline Peripatus basilensis & MCZ-IZ131422 & DNA104977 & Dominican Republic & $\bullet$ & $\bullet$ & $\bullet$ & $\bullet$ \\
\hline Mesoperipatus tholloni & MCZ-IZ131381 & DNA104625 & Gabon & $\bullet$ & $\bullet$ & $\bullet$ & $\bullet$ \\
\hline Principapillatus hitoyensis & MCZ-131339 & DNA103564 & Costa Rica, Limón & $\bullet$ & $\bullet$ & $\bullet$ & $\bullet$ \\
\hline Cerradopatus sucuriuensis & GENBANK & KM095127.1 & Brazil, Mato Grosso do Sul state, Chapadão do Sul municipality & $\bullet$ & $\bullet$ & $\circ$ & $\circ$ \\
\hline Epiperipatus diadenoproctus & GENBANK & ms2; HQ236094.1/HQ236120.1 & Brazil, Minas Gerais state, Simonésia municipality & $\bullet$ & $\bullet$ & $\circ$ & $\circ$ \\
\hline Epiperipatus diadenoproctus & GENBANK & ms3; HQ236095.1/HQ236121.1 & Brazil, Minas Gerais state, Simonésia municipality & - & - & 0 & $\circ$ \\
\hline Epiperipatus diadenoproctus & GENBANK & ms4; HQ236096.1/HQ236122.1 & Brazil, Minas Gerais state, Simonésia municipality & $\bullet$ & $\bullet$ & o & ○ \\
\hline Epiperipatus diadenoproctus & GENBANK & ms5; HQ236097.1/HQ236123.1 & Brazil, Minas Gerais state, Simonésia municipality & $\bullet$ & $\bullet$ & o & $\circ$ \\
\hline Epiperipatus paurognostus & GENBANK & me2; HQ236099.1/HQ236125.1 & Brazil, Minas Gerais state, Piedade de Caratinga municipality & $\bullet$ & $\bullet$ & $\circ$ & $\circ$ \\
\hline Epiperipatus paurognostus & GENBANK & me3; HQ236100.1/HQ236126.1 & Brazil, Minas Gerais state, Piedade de Caratinga municipality & $\bullet$ & $\bullet$ & o & $\circ$ \\
\hline Epiperipatus paurognostus & GENBANK & me4; HQ236101.1/HQ236127.1 & Brazil, Minas Gerais state, Piedade de Caratinga municipality & $\bullet$ & $\bullet$ & $\circ$ & $\circ$ \\
\hline Epiperipatus paurognostus & GENBANK & me5; HQ236102.1/HQ236128.1 & Brazil, Minas Gerais state, Piedade de Caratinga municipality & $\bullet$ & $\bullet$ & o & $\circ$ \\
\hline Epiperipatus paurognostus & GENBANK & me6; HQ236103.1/HQ236129.1 & Brazil, Minas Gerais state, Piedade de Caratinga municipality & $\bullet$ & $\bullet$ & $\circ$ & $\circ$ \\
\hline Epiperipatus paurognostus & GENBANK & me7; HQ236104.1/HQ236130.1 & Brazil, Minas Gerais state, Piedade de Caratinga municipality & $\bullet$ & $\bullet$ & $\circ$ & $\circ$ \\
\hline Epiperipatus paurognostus & GENBANK & me8; HQ236105.1/HQ236131.1 & Brazil, Minas Gerais state, Piedade de Caratinga municipality & $\bullet$ & $\bullet$ & $\circ$ & $\circ$ \\
\hline Epiperipatus paurognostus & GENBANK & me9; HQ236106.1/HQ236132.1 & Brazil, Minas Gerais state, Piedade de Caratinga municipality & $\bullet$ & $\bullet$ & $\circ$ & $\circ$ \\
\hline Epiperipatus paurognostus & GENBANK & me10; HQ236107.1/HQ236133.1 & Brazil, Minas Gerais state, Piedade de Caratinga municipality & $\bullet$ & $\bullet$ & $\circ$ & $\circ$ \\
\hline Epiperipatus adenocryptus & GENBANK & cs1; HQ236108.1/ HQ236134.1 & Brazil, Minas Gerais state, Santa Bárbara do Leste municipality & $\bullet$ & - & $\circ$ & $\circ$ \\
\hline Epiperipatus adenocryptus & GENBANK & cs2; HQ236109.1/ HQ236135.1 & Brazil, Minas Gerais state, Santa Bárbara do Leste municipality & - & - & $\circ$ & $\circ$ \\
\hline Epiperipatus adenocryptus & GENBANK & cs3; HQ236110.1/ HQ236136.1 & Brazil, Minas Gerais state, Santa Bárbara do Leste municipality & $\bullet$ & $\bullet$ & $\circ$ & $\circ$ \\
\hline Epiperipatus adenocryptus & GENBANK & cs4; HQ236111.1/HQ236137.1 & Brazil, Minas Gerais state, Santa Bárbara do Leste municipality & $\bullet$ & $\bullet$ & ○ & $\circ$ \\
\hline Epiperipatus adenocryptus & GENBANK & cs5; HQ236112.1/HQ236138.1 & Brazil, Minas Gerais state, Santa Bárbara do Leste municipality & - & - & 0 & $\circ$ \\
\hline Epiperipatus adenocryptus & GENBANK & cs6; HQ236113.1/HQ236139.1 & Brazil, Minas Gerais state, Santa Bárbara do Leste municipality & $\bullet$ & $\bullet$ & o & $\circ$ \\
\hline Epiperipatus adenocryptus & GENBANK & cs7; HQ236114.1/HQ236140.1 & Brazil, Minas Gerais state, Santa Bárbara do Leste municipality & $\bullet$ & $\bullet$ & $\circ$ & $\circ$ \\
\hline
\end{tabular}

Legend: • fragments sequenced; ○ fragments not sequenced. Names of the institutions: MNRJ -

Museu Nacional do Rio de Janeiro; MZUSP - Museu de Zoologia da Universidade de São Paulo;

UFMG - Universidade Federal de Minas Gerais; Ony - Universidade Federal do Mato Grosso do

Sul; UFPB - Universidade Federal da Paraíba; CHNUFPI - Universidade Federal do Piauí; ICN-

ONY - Universidade Nacional de Colombia; UNACHI - Universidade Autonoma de Chiriquí;

MCZ, FG - Museum of Comparative Zoology; GB - Genbank. 
Table S.2. Compiled morphological matrix for 131 specimens examined (1/3).

\begin{tabular}{|c|c|c|c|c|c|c|c|c|c|c|c|c|c|c|c|c|c|c|c|c|c|c|c|c|c|c|c|c|c|c|c|c|c|}
\hline Espécie/caracter & 0 & 1 & 2 & 3 & 4 & 5 & 6 & 7 & 8 & 9 & 10 & 11 & 12 & 13 & 14 & 15 & 16 & 17 & 18 & 19 & 20 & 21 & 22 & 23 & 24 & 25 & 26 & 27 & 28 & 29 & 30 & 31 & $32+>>>$ \\
\hline$\overline{\text { Peripatopsis lawrencei [iz131348] }}$ & 1 & 0 & $\overline{0}$ & & 0 & 1 & 0 & & 1 & 0 & & $\overline{0}$ & $?$ & $\underline{I}$ & & & & 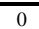 & & $\overline{1}$ & $\overline{0}$ & $\overline{0}$ & & $\overline{0}$ & $\overline{1}$ & & - & 0 & 1 & 0 & 0 & 然 & \\
\hline Peripatopsis moseleyi [iz131346] & 1 & 0 & 0 & -3 & 0 & 1 & 1 & 0 & 1 & & - & 0 & ? & - & - & - & - & 0 & - & 1 & 0 & 0 & - & 0 & 1 & - & - & 0 & 0 & - & - & - & - \\
\hline Metaperipatus inae [ony_114] & 1 & 0 & 0 & - & 0 & 1 & 0 & - & 1 & 1 & 0 & 0 & 1 & - & - & - & - & 0 & 1 & 0 & 0 & 1 & 1 & 1 & 1 & 3 & - & 0 & 0 & - & - & 1 & 1 \\
\hline Eoperipatus cf. horsti [iz131341] & 0 & 0 & 0 & - & 0 & 0 & ? & ? & ? & ? & ? & 0 & ? & 1 & 2 & 0 & ? & 1 & 0 & 0 & 0 & 0 & & 1 & 0 & 0 & & 3 & 0 & & & 1 & 1 \\
\hline Mesoperipatus tholloni [iz131381] & 0 & 0 & 0 & - & 0 & 0 & 1 & 0 & 0 & 1 & 0 & 0 & 2 & 1 & 0 & 1 & 1 & 1 & 1 & 1 & 0 & 0 & - & 0 & 0 & 3 & - & 2 & - & - & - & - & - \\
\hline Peripatus basilensis [iz131422] & 0 & 1 & 1 & 0 & 0 & 0 & 1 & 0 & 0 & 1 & 0 & 0 & ? & 1 & 0 & 1 & ? & 1 & 0 & 1 & 0 & 0 & & 1 & 0 & 0 & - & 2 & - & - & - & - & \\
\hline Principapillatus hitoyensis [iz131339] & 0 & $0 \& 1$ & $0 \& 1$ & 0 & 0 & 0 & 1 & 0 & 0 & 1 & 0 & 0 & 1 & 0 & 0 & 1 & 1 & 1 & 0 & 1 & 0 & 0 & - & 1 & 0 & 1 & - & 2 & - & - & - & - & - \\
\hline Cerradopatus sucuriuensis [ONY-MTS08] & 0 & 1 & 0 & & 0 & 0 & 1 & 0 & 0 & 1 & 0 & 0 & 1 & 1 & 0 & 1 & 1 & 1 & 1 & 1 & $0 \& 1$ & 0 & & 1 & 0 & 2 & - & 2 & - & - & - & - & \\
\hline Oroperipatus sp. [ony_013] & 0 & 1 & 1 & 0 & 0 & 0 & 1 & 0 & 0 & 1 & 1 & 0 & ? & 1 & 0 & 1 & ? & 1 & 1 & 1 & 1 & 0 & - & 1 & 2 & 0 & - & 1 & - & - & - & - & - \\
\hline Oroperipatus sp. [ony_014] & 0 & 1 & 1 & 0 & 0 & 0 & 1 & 0 & 0 & 1 & 1 & 0 & ? & 1 & 0 & 1 & ? & 1 & 1 & 1 & 1 & 0 & & 1 & 2 & 0 & & 1 & - & - & - & - & \\
\hline Oroperipatus corradoi [ony_005] & 0 & 1 & 1 & 0 & 0 & 0 & 1 & 0 & 0 & 1 & 0 & 0 & 1 & 1 & 0 & $0 \& 1$ & 1 & 1 & 0 & 1 & 1 & 0 & - & 1 & 2 & 0 & - & 1 & - & - & - & - & - \\
\hline Oroperipatus cf. corradoi [ony_006] & 0 & ? & ? & ? & 0 & 0 & 1 & 0 & 0 & 1 & 1 & 0 & ? & 1 & 0 & 1 & ? & 1 & 1 & 1 & 1 & 0 & & 1 & 2 & 0 & & 1 & - & - & - & - & \\
\hline Epiperipatus n. sp. [ony_112] & 0 & 1 & 1 & 1 & 0 & 0 & 1 & 0 & 0 & 1 & 0 & 0 & ? & 1 & 0 & 1 & ? & 1 & 0 & 1 & 0 & 0 & - & 2 & 0 & 0 & 1 & 2 & - & - & - & - & \\
\hline Peripatus bouvieri [ony_074] & 0 & 1 & 1 & 0 & 0 & 0 & 1 & 0 & 0 & 1 & 0 & 0 & 0 & 1 & 3 & - & ? & 1 & 0 & 1 & 0 & 0 & & 2 & 0 & 0 & 1 & 2 & 1 & 0 & 1 & 1 & 1 \\
\hline Peripatus bouvieri [ony_075] & 0 & 0 & 0 & - & 0 & 0 & 1 & 1 & 0 & 1 & 1 & 0 & 0 & 1 & 3 & - & ? & 1 & 0 & 1 & 0 & 0 & - & 2 & 0 & 0 & 1 & 2 & & - & - & - & \\
\hline Peripatus bouvieri [ony_076] & 0 & 0 & 0 & - & 0 & 0 & 1 & 0 & 0 & 1 & 1 & 0 & 0 & 1 & 3 & - & ? & 1 & 0 & 1 & 0 & 0 & & 2 & 0 & 0 & 1 & 2 & - & - & - & - & \\
\hline Epiperipatus n. sp. [ony_071] & 0 & 1 & 1 & 0 & 0 & ? & 1 & 0 & 0 & 1 & 0 & 0 & $?$ & 1 & 0 & ? & $?$ & 1 & 0 & 1 & 0 & 0 & - & 1 & 0 & 0 & - & 2 & 1 & 1 & 1 & 1 & 0 \\
\hline Epiperipatus n. sp. [ony_052] & 0 & 1 & 1 & 0 & 0 & 0 & 1 & 0 & 0 & 1 & 0 & 0 & ? & ? & 0 & 1 & ? & 1 & 0 & 1 & 0 & 0 & & 1 & 0 & 0 & - & 2 & 1 & 0 & 0 & 1 & 0 \\
\hline Epiperipatus n. sp. [ony_053] & 0 & 1 & ? & ? & 0 & 0 & 1 & 0 & 0 & 1 & 0 & 0 & ? & ? & 0 & 1 & ? & 1 & 0 & 1 & 0 & 0 & - & 1 & 0 & 0 & - & 2 & - & - & - & - & \\
\hline Epiperipatus n. sp. [sp10] [ony_078] & 0 & 1 & 1 & 0 & 0 & 0 & 1 & 0 & 0 & 1 & 1 & 0 & 1 & 0 & 2 & 1 & 1 & 1 & 0 & 1 & 0 & 0 & & 1 & 0 & 0 & - & 2 & 1 & 0 & 1 & 1 & 0 \\
\hline Epiperipatus n. sp. [sp10] [ony_079] & 0 & 1 & 1 & 0 & 0 & 0 & 1 & 0 & 0 & 1 & 0 & 0 & ? & ? & ? & 1 & ? & 1 & 0 & 1 & 0 & 0 & - & 1 & 0 & 0 & - & 2 & 1 & 1 & $0 \& 1$ & 1 & 0 \\
\hline Epiperipatus n. sp. [sp10] [ony_080] & 0 & 1 & ? & ? & 0 & 0 & 1 & 0 & 0 & 1 & 0 & 0 & ? & ? & ? & 1 & ? & 1 & 0 & 1 & 0 & 0 & & 1 & 0 & 2 & - & 2 & 1 & 0 & 1 & 1 & 0 \\
\hline Epiperipatus n. sp. [sp10] [ony_081] & 0 & 1 & 1 & 0 & 0 & 0 & 1 & 0 & 0 & 1 & 0 & 0 & ? & ? & ? & 1 & ? & 1 & 0 & 1 & 0 & 0 & - & 1 & 0 & 2 & - & 2 & 1 & 1 & $0 \& 1$ & 1 & 0 \\
\hline Epiperipatus n. sp. [sp10] [ony_082] & 0 & 1 & 1 & 0 & 0 & 0 & 1 & 0 & 0 & 1 & 0 & 0 & ? & ? & ? & 1 & ? & 1 & 0 & 1 & 0 & 0 & & 1 & 0 & 0 & - & 2 & 1 & 0 & 1 & 1 & \\
\hline Epiperipatus n. sp. [sp10] [ony_083] & 0 & 1 & 1 & 0 & 0 & 0 & 1 & 0 & 0 & 1 & 0 & 0 & ? & ? & ? & 1 & ? & 1 & 0 & 1 & 0 & 0 & - & 1 & 0 & 2 & - & 2 & - & - & - & - & \\
\hline Epiperipatus sp. [ony_062a] & 0 & ? & 1 & 0 & 0 & 0 & ? & ? & 0 & ? & ? & 0 & ? & ? & 0 & 1 & ? & 1 & 0 & 1 & 0 & 0 & & 1 & 0 & 3 & - & 2 & 1 & 1 & 1 & ? & \\
\hline Epiperipatus sp. [ony_062b] & 0 & ? & 1 & 0 & 0 & 0 & ? & ? & $?$ & ? & ? & 0 & ? & ? & 0 & 1 & ? & 1 & 0 & 1 & 0 & 0 & & 1 & 0 & 3 & - & 2 & 0 & - & - & - & - \\
\hline Epiperipatus isthmicola [ony_061] & 0 & 1 & 1 & 0 & 0 & 0 & 1 & 0 & 0 & 1 & 0 & 0 & 1 & 1 & 0 & 1 & 1 & 1 & 0 & 1 & 0 & 0 & & 1 & 0 & 0 & - & 2 & & & & & \\
\hline Peripatus solorzanoi [ony_064] & 0 & 0 & 0 & 0 & 0 & 0 & ? & ? & ? & ? & ? & 0 & 1 & 0 & 0 & 1 & 2 & 1 & 0 & 1 & 0 & 0 & - & 1 & 0 & 2 & - & 2 & 1 & 2 & $0 \& 1$ & 1 & 0 \\
\hline Epiperipatus sp. [ony_072] & 0 & 1 & 0 & ? & ? & 0 & 1 & 0 & 0 & $i$ & 0 & 0 & 1 & 1 & 0 & 1 & 1 & 1 & 0 & 1 & 0 & 0 & & 1 & 0 & 0 & - & 2 & - & - & - & - & \\
\hline Epiperipatus sp. [ony_058] & 0 & ? & ? & ? & 0 & 0 & 1 & 0 & 0 & 1 & 0 & 0 & ? & ? & 0 & 1 & ? & 1 & 0 & 1 & 0 & 0 & - & 1 & 0 & 0 & - & 2 & - & - & - & - & \\
\hline Epiperipatus biolleyi [on__060a] & 0 & 0 & 0 & - & 0 & 0 & 1 & 0 & 0 & 1 & 0 & 0 & 1 & $0 \& 1$ & 0 & & 1 & 1 & 0 & 1 & 0 & 0 & & 1 & 0 & 0 & & & & & & & \\
\hline Epiperipatus biolleyi [ony_060b] & 0 & 0 & 0 & - & 0 & 0 & 1 & 0 & 0 & 1 & 0 & 0 & 1 & $0 \& 1$ & 0 & 1 & 1 & 1 & 0 & 1 & 0 & 0 & & 1 & 0 & 0 & - & 2 & 1 & 1 & 1 & 1 & ? \\
\hline Peripatus solorzanoi [ony_063] & 0 & 0 & 0 & & 0 & 0 & ? & ? & ? & ? & ? & 0 & 1 & 0 & 0 & 1 & 2 & 1 & 0 & 1 & 0 & 0 & & 1 & 0 & 0 & - & 2 & - & - & - & - & \\
\hline Epiperipatus sp. [ony_113] & 0 & ? & ? & ? & 0 & 0 & 1 & 0 & 0 & 1 & 0 & 0 & ? & ? & 0 & 1 & ? & 1 & 0 & 1 & 0 & 0 & - & 1 & 0 & 0 & - & 2 & - & - & - & - & \\
\hline Epiperipatus morfosp4 [ony_084] & 0 & 1 & 1 & 0 & 0 & 0 & 1 & 0 & 0 & 1 & 1 & 0 & ? & 1 & ? & ? & ? & 1 & 0 & 1 & 0 & 0 & & 2 & 0 & 0 & $1 \& 2$ & 2 & - & - & - & - & - \\
\hline Epiperipatus edwardsii [ony_059] & 0 & 1 & 1 & 0 & 0 & 0 & 1 & 0 & 0 & 1 & 0 & 0 & 1 & 1 & 0 & 1 & 1 & 1 & 0 & 1 & 0 & 0 & - & 1 & 0 & $0 \& 2$ & - & 2 & 0 & - & - & 1 & 0 \\
\hline Epiperipatus sp. [ony_092] & 0 & ? & ? & ? & ? & ? & ? & ? & $?$ & ? & ? & ? & ? & ? & ? & ? & ? & ? & ? & ? & ? & ? & ? & ? & ? & $?$ & ? & ? & ? & ? & ? & ? & ? \\
\hline Epiperipatus sp. [ony_085] & 0 & ? & ? & ? & 0 & 0 & 1 & 0 & 0 & 1 & 0 & 0 & ? & 1 & 0 & 1 & ? & 1 & 0 & 1 & 0 & 0 & - & 1 & 0 & 0 & - & 2 & - & - & - & - & \\
\hline Epiperipatus sp. [ony_086] & 0 & ? & ? & ? & 0 & 0 & ? & ? & 0 & ? & ? & 0 & ? & 1 & 0 & & ? & 1 & 0 & 1 & 0 & 0 & & 1 & 0 & 0 & - & & & & - & & \\
\hline Epiperipatus sp. [ony_087] & 0 & ? & ? & ? & 0 & 0 & 0 & - & 0 & 1 & 0 & 0 & ? & 1 & 0 & 1 & ? & 1 & 0 & 1 & 0 & 0 & - & 1 & 0 & 0 & - & 1 & - & - & - & - & \\
\hline Epiperipatus sp. [ony_091] & 0 & ? & 1 & ? & 0 & 0 & 1 & 0 & 0 & 1 & 0 & 0 & ? & 1 & 0 & 1 & ? & 1 & 0 & 1 & 0 & 0 & - & 1 & 0 & 0 & - & 2 & 1 & 1 & 0 & 1 & 0 \\
\hline Epiperipatus sp. [ony_077] & 0 & 1 & 1 & 0 & 0 & 0 & 1 & 0 & 0 & 1 & 0 & 0 & ? & 1 & 0 & 1 & ? & 1 & 1 & 1 & 0 & 0 & - & 1 & 0 & 0 & - & 2 & & - & 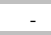 & & \\
\hline s cratensis [ony_115] & 0 & ? & ? & ? & ? & ? & ? & ? & ? & ? & ? & ? & ? & ? & $?$ & ? & ? & ? & ? & ? & ? & ? & ? & ? & ? & ? & ? & ? & ? & ? & ? & ? & ? \\
\hline Genus sp. [ony_094] & 0 & ? & ? & ? & 0 & 0 & ? & $?$ & ? & ? & ? & ? & ? & ? & 0 & ? & ? & 1 & 1 & 1 & 0 & 0 & - & 1 & 0 & 0 & - & 2 & - & - & - & - & \\
\hline Genus sp. [ony_095] & 0 & ? & ? & ? & 0 & 0 & 1 & 0 & 0 & 1 & 0 & ? & ? & ? & 0 & ? & ? & 1 & 1 & 1 & 0 & 0 & & 1 & 0 & 0 & & 2 & 1 & ? & ? & ? & $?$ \\
\hline Epiperipatus n. sp. [troglobius] [ony_022] & 0 & 1 & $?$ & & 1 & 0 & 1 & 0 & 0 & 1 & $0 \& 1$ & 1 & 1 & 1 & 0 & 1 & 1 & 1 & 1 & 2 & 1 & 0 & & 2 & 0 & 0 & $0 \& 3$ & 2 & 1 & 2 & 0 & 1 & 0 \\
\hline
\end{tabular}


Table S.2. (Continued, 2/3)

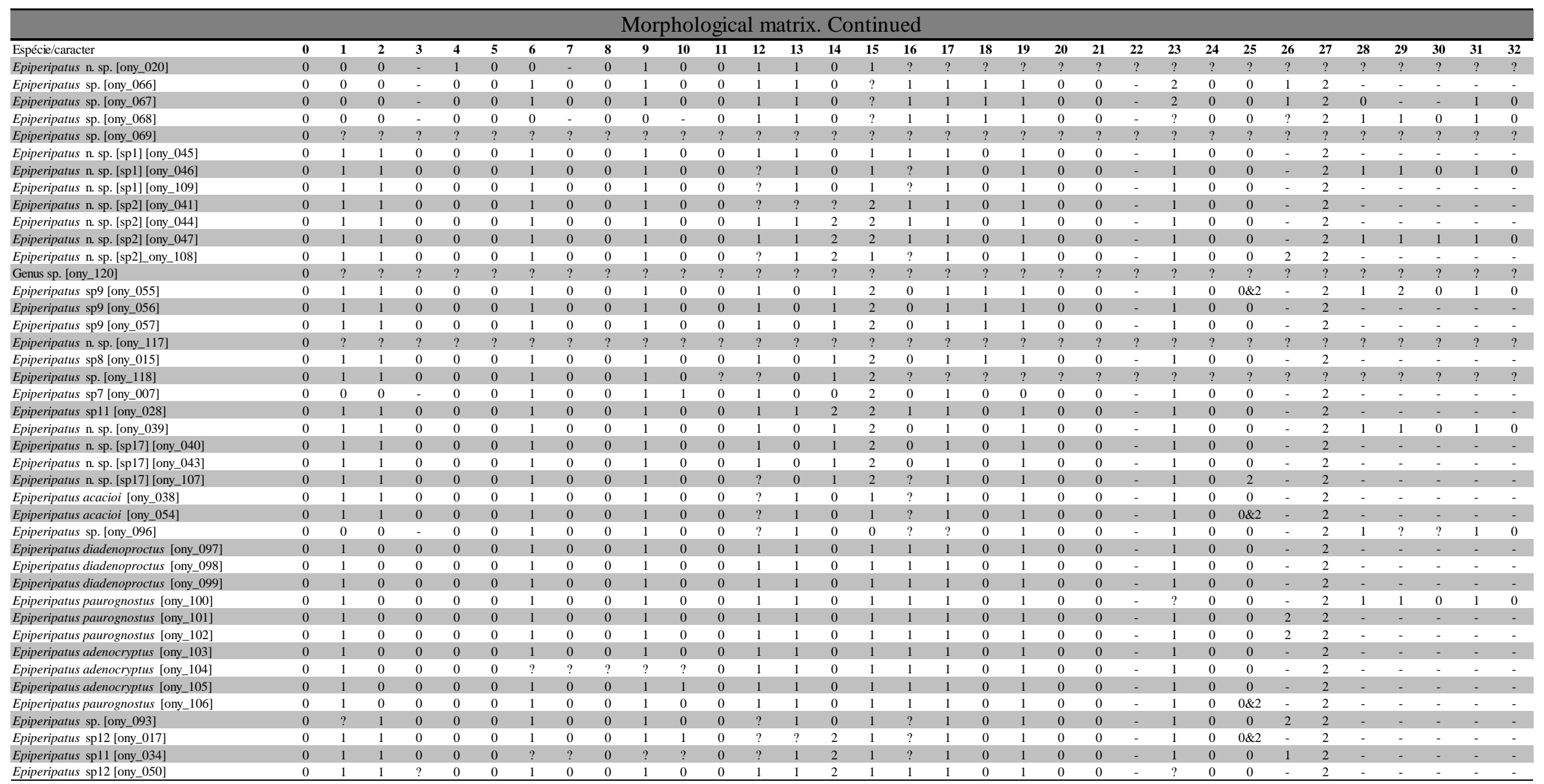


Table S.2. (Continued, 3/3)

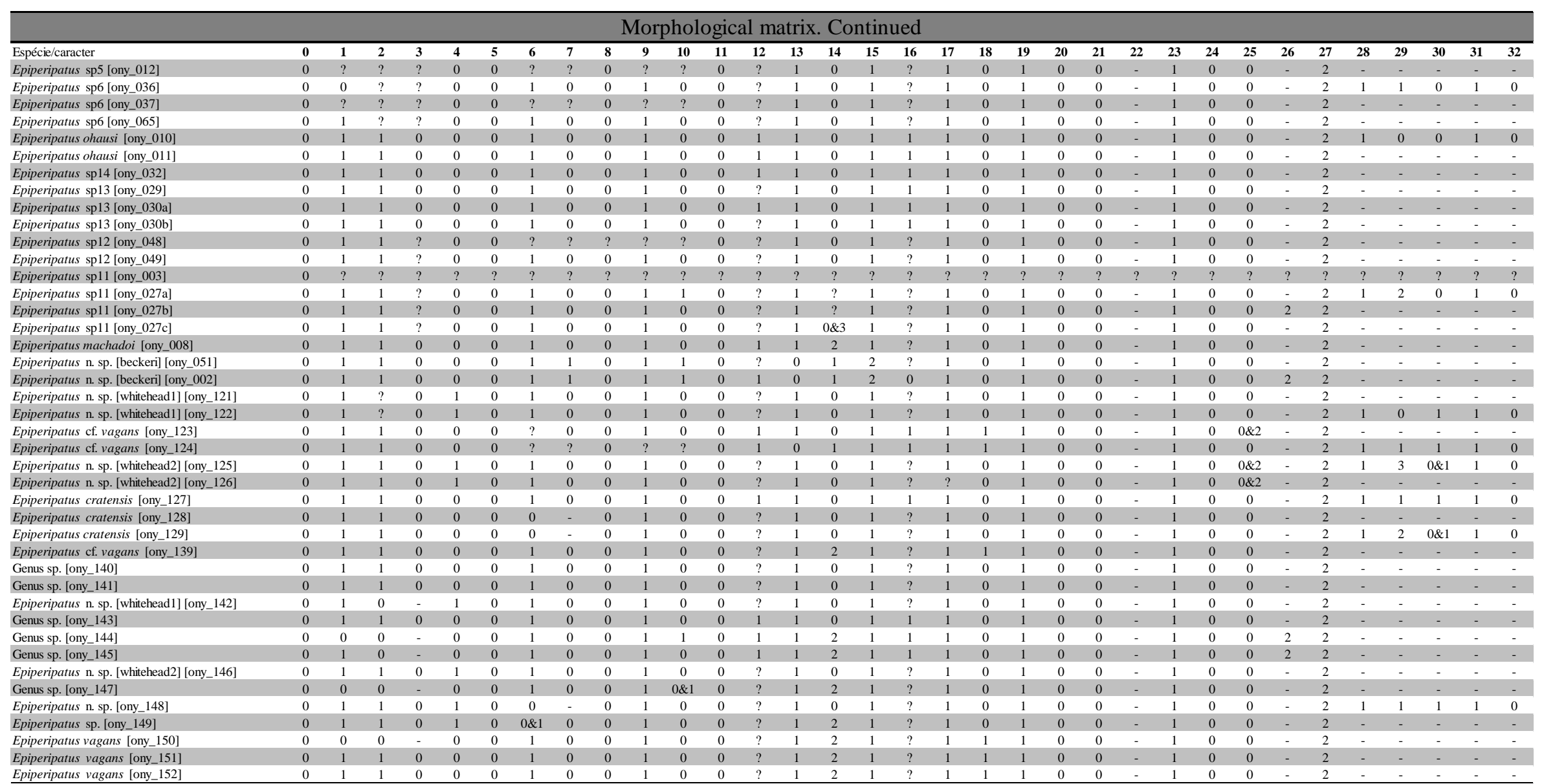


Table S.3. Locations and identities of molecular unambiguous synapomorphies and morphology support for Peripatidae clades (1/5).

\begin{tabular}{ccccc}
\hline \multicolumn{5}{c}{ Neotropical group (clade D+E) } \\
\hline COI & $\mathbf{1 2 S}$ & $\mathbf{1 6 S}$ & $\mathbf{1 8 S}$ & Morphology \\
\hline $122: 0$ & $56: 3$ & $278: 3$ & $51: 0$ & $1: 1$ \\
$225: 0$ & $59: 3$ & $279: 3$ & $62: 3$ & $2: 1$ \\
462:0 & $109: 0$ & $288: 3$ & $126: 1$ & \\
& $110: 0$ & $309: 3$ & $209: 2$ & \\
& $138: 3$ & $406: 0$ & $215: 3$ & \\
& $214: 0$ & $418: 0$ & $859: 0$ & \\
& $231: 0$ & $430: 3$ & $1677: 3$ & \\
& $304: 0$ & $437: 3$ & $1726: 0$ & \\
& $369: 3$ & $469: 3$ & & \\
& $416: 0$ & & & \\
$421: 3$ & & & \\
$434: 0$ & & & \\
$480: 0$ & & &
\end{tabular}

\begin{tabular}{|c|c|c|c|c|}
\hline \multicolumn{5}{|c|}{ Oroperipatus (clade E) } \\
\hline COI & $12 S$ & $16 \mathrm{~S}$ & $18 \mathrm{~S}$ & Morphology \\
\hline 383:0 & 11:3 & 19:0 & $40: 1$ & 20:1 \\
\hline 403:2 & 29:0 & $44: 3$ & 195:3 & $24: 2$ \\
\hline 414:2 & $60: 1$ & 60:0 & 1773:1 & 27:1 \\
\hline 488:3 & $61: 1$ & $134: 4$ & & \\
\hline \multirow[t]{21}{*}{ 632:0 } & 79:2 & 262:0 & & \\
\hline & $91: 3$ & 277:3 & & \\
\hline & 106:3 & 312:3 & & \\
\hline & $118: 3$ & 320:4 & & \\
\hline & 142:3 & $323: 0$ & & \\
\hline & 159:3 & $361: 1$ & & \\
\hline & 172:0 & 381:3 & & \\
\hline & 181:2 & 411:0 & & \\
\hline & 229:3 & 440:3 & & \\
\hline & 263:4 & & & \\
\hline & 342:1 & & & \\
\hline & 359:0 & & & \\
\hline & 360:0 & & & \\
\hline & 407:0 & & & \\
\hline & 441:4 & & & \\
\hline & 487:2 & & & \\
\hline & 497:2 & & & \\
\hline & 502:0 & & & \\
\hline & 523:0 & & & \\
\hline & $542: 3$ & & & \\
\hline & $543: 3$ & & & \\
\hline
\end{tabular}

\begin{tabular}{ccccc}
\hline \multicolumn{5}{c}{ Epiperipatus (clade D) } \\
\hline COI & $\mathbf{1 2 S}$ & $\mathbf{1 6 S}$ & $\mathbf{1 8 S}$ & Morphology \\
\hline $12: 2$ & $53: 3$ & $18: 0$ & $197: 2$ & \\
$17: 2$ & $63: 1$ & $34: 1$ & & \\
$284: 0$ & $113: 3$ & $37: 3$ & & \\
$339: 1$ & $254: 0$ & $49: 0$ & & \\
$341: 3$ & $255: 0$ & $73: 3$ & & \\
$353: 0$ & $313: 0$ & $88: 0$ & & \\
$479: 3$ & $431: 4$ & $109: 2$ & & \\
& $492: 4$ & $111: 2$ & & \\
& $495: 0$ & $142: 1$ & \\
& $513: 4$ & $157: 4$ & \\
& $521: 1$ & $167: 0$ & \\
& $525: 0$ & $180: 4$ & \\
& $527: 2$ & $192: 2$ & \\
& $550: 1$ & $199: 0$ & \\
& $202: 1$ & & \\
& $264: 3$ & & \\
& $271: 0$ & & \\
& $286: 4$ & & \\
& $293: 3$ & & \\
& $298: 4$ & & \\
& $304: 3$ & & \\
& $310: 0$ & & \\
$358: 0$ & & \\
$429: 3$ & & \\
$431: 2$ & & \\
$439: 3$ & & \\
\hline
\end{tabular}


Table S.3. (Continued, 2/5)

\begin{tabular}{|c|c|c|c|c|}
\hline \multicolumn{5}{|c|}{ Brazilian group (clade L) } \\
\hline COI & $12 \mathrm{~S}$ & $16 \mathrm{~S}$ & $18 \mathrm{~S}$ & Morphology \\
\hline 415:2 & $110: 3$ & 159:0 & $64: 3$ & $30: 0$ \\
\hline 423:3 & 208:3 & 426:0 & 102:0 & \\
\hline 461:0 & 251:0 & $465: 3$ & 111:0 & \\
\hline 479:0 & $369: 0$ & $124: 3$ & & \\
\hline & 402:4 & 297:0 & & \\
\hline & 421:0 & 407:3 & & \\
\hline & 425:0 & 417:1 & & \\
\hline & 427:0 & & & \\
\hline & $428: 3$ & & & \\
\hline & 441:3 & & & \\
\hline & 452:0 & & & \\
\hline & $488: 3$ & & & \\
\hline & 543:2 & & & \\
\hline & 610:4 & & & \\
\hline & 1156:0 & & & \\
\hline & 1176:1 & & & \\
\hline & 1192:3 & & & \\
\hline & $1217: 2$ & & & \\
\hline & $1350: 2$ & & & \\
\hline & 1371:1 & & & \\
\hline & 1397:0 & & & \\
\hline & 1412:3 & & & \\
\hline & 1475:3 & & & \\
\hline & 1484:2 & & & \\
\hline & 1490:3 & & & \\
\hline & 1493:1 & & & \\
\hline & $1500: 3$ & & & \\
\hline & 1527:0 & & & \\
\hline & 1908:0 & & & \\
\hline
\end{tabular}

Three species of Epiperipatus : $E$ adenocryptus, $E$. diadenoproctus, E. paurognostus (clade $\mathbf{R}$ )

\begin{tabular}{ccccc}
\hline COI & $\mathbf{1 2 S}$ & $\mathbf{1 6 S}$ & $\mathbf{1 8 S}$ & Morphology \\
\hline $225: 3$ & $20: 3$ & & &
\end{tabular}

428:3 $100 \cdot 3$

443:2 $\quad 107: 0$

548:3 $\quad 167: 2$

171:0

287:0

$302: 1$
$504: 0$

521:0

524:1

528:0

530:0

531:0

Epiperipatus [sp1] n. sp. (clade O)

\begin{tabular}{ccccc}
\hline COI & $\mathbf{1 2 S}$ & $\mathbf{1 6 S}$ & $\mathbf{1 8 S}$ & Morphology \\
\hline $32: 3$ & $42: 0$ & $7: 0$ & $55: 1$ & \\
$80: 2$ & $59: 0$ & $29: 0$ & $281: 1$ & \\
$101: 2$ & $87: 2$ & $34: 3$ & $306: 3$ & \\
$173: 2$ & $92: 1$ & $59: 2$ & $470: 1$ & \\
$230: 0$ & $136: 0$ & $88: 3$ & $476: 0$ & \\
$239: 0$ & $306: 4$ & $101: 3$ & & \\
$248: 0$ & $308: 3$ & $151: 0$ & & \\
$260: 2$ & $328: 3$ & $243: 2$ & & \\
$287: 3$ & $343: 3$ & $278: 2$ & & \\
$353: 3$ & $515: 0$ & $279: 2$ & & \\
$392: 1$ & $521: 3$ & $285: 0$ & & \\
$398: 2$ & $545: 1$ & $364: 0$ & & \\
$405: 0$ & $550: 3$ & & & \\
$414: 2$ & $551: 3$ & & & \\
$479: 2$ & & & & \\
$485: 0$ & & & & \\
$494: 3$ & & & &
\end{tabular}


Table S.3. (Continued, 3/5)

\begin{tabular}{|c|c|c|c|c|c|c|c|c|c|}
\hline \multicolumn{5}{|c|}{ Epiperipatus [sp2] n. sp. (clade N) } & \multicolumn{5}{|c|}{ Epiperipatus $[$ sp10] n. sp. (clade U) } \\
\hline COI & $12 \mathrm{~S}$ & $16 \mathrm{~S}$ & $18 \mathrm{~S}$ & Morphology & COI & $12 \mathrm{~S}$ & $16 \mathrm{~S}$ & $18 \mathrm{~S}$ & Morphology \\
\hline $14: 2$ & 334:1 & $98: 2$ & & & $2: 3$ & & & & \\
\hline 23:1 & $408: 3$ & $131: 2$ & & & 41:2 & & & & \\
\hline 41:2 & 471:1 & 192:0 & & & $92: 2$ & & & & \\
\hline 77:2 & 503:0 & 259:0 & & & $122: 2$ & & & & \\
\hline 98:0 & & & & & $143: 2$ & & & & \\
\hline 125:1 & & & & & 155:1 & & & & \\
\hline 197:2 & & & & & 182:1 & & & & \\
\hline 209:2 & & & & & $185: 2$ & & & & \\
\hline 413:2 & & & & & $221: 2$ & & & & \\
\hline 512:2 & & & & & $236: 2$ & & & & \\
\hline 593:2 & & & & & 257:0 & & & & \\
\hline & & & & & 290:1 & & & & \\
\hline & & & & & 390:2 & & & & \\
\hline & & & & & $410: 2$ & & & & \\
\hline & & & & & 414:2 & & & & \\
\hline & & & & & 422:2 & & & & \\
\hline & & & & & 449:2 & & & & \\
\hline & & & & & 452:2 & & & & \\
\hline & & & & & $467: 2$ & & & & \\
\hline & & & & & 500:0 & & & & \\
\hline & & & & & $515: 2$ & & & & \\
\hline
\end{tabular}

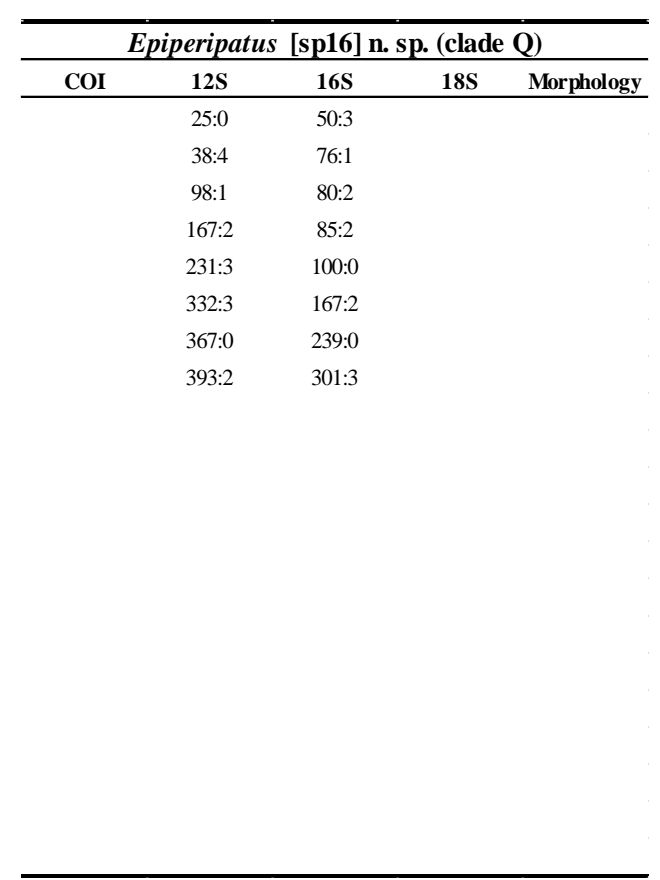


Table S.3. (Continued, 4/5)

\begin{tabular}{ccccc}
\hline \multicolumn{5}{c}{ Epiperipatus lucerus [sp17] } \\
\hline COI & $12 \mathrm{~S}$ & $16 \mathrm{~S}$ & $18 \mathrm{~S}$ & Morphology \\
\hline $248: 0$ & $546: 2$ & $93: 2$ & & \\
& & $371: 3$ & & \\
& & & & \\
& & & \\
& & & \\
\hline
\end{tabular}

\begin{tabular}{ccccc}
\hline \multicolumn{5}{c}{ Epiperipatus ohausi (clade $\mathbf{S}$ ) } \\
\hline COI & $12 S$ & $16 \mathrm{~S}$ & $18 \mathrm{~S}$ & Morphology \\
\hline $20: 1$ & & & & \\
$29: 2$ & & & & \\
$53: 2$ & & & & \\
$65: 0$ & & & \\
$200: 2$ & & & \\
$308: 2$ & & & \\
$362: 2$ & & & & \\
$422: 2$ & & & & \\
$449: 2$ & & & \\
$524: 2$ & & & \\
\hline
\end{tabular}

Epiperipatus solorzanoi

\begin{tabular}{|c|c|c|c|c|}
\hline \multicolumn{5}{|c|}{ Epiperipatus solorzanoi } \\
\hline $\mathrm{COI}$ & $12 \mathrm{~S}$ & $16 \mathrm{~S}$ & $18 \mathrm{~S}$ & Morphology \\
\hline & & & & 1:0 \\
\hline & & & & 13:0 \\
\hline & & & & $16: 2$ \\
\hline
\end{tabular}


Table S.3. (Continued, 5/5)

\begin{tabular}{ccccc}
\hline \multicolumn{5}{c}{ Epiperipatus cratensis } \\
\hline COI & 12 S & $16 \mathrm{~S}$ & $18 \mathrm{~S}$ & Morphology \\
\hline & $33: 3$ & $34: 3$ & $446: 1$ & \\
& $38: 0$ & $57: 2$ & $447: 3$ & \\
$100: 1$ & $167: 2$ & $1344: 1$ & \\
& $287: 1$ & $240: 3$ & $1589: 3$ & \\
$344: 1$ & $260: 0$ & & \\
& $415: 1$ & $419: 3$ & & \\
$471: 1$ & & & \\
$504: 1$ & & & \\
& $517: 0$ & & &
\end{tabular}

\begin{tabular}{|c|c|c|c|c|}
\hline \multicolumn{5}{|c|}{ Epiperipatus bouvieri } \\
\hline $\mathrm{COI}$ & $12 \mathrm{~S}$ & $16 \mathrm{~S}$ & $18 \mathrm{~S}$ & Morphology \\
\hline $20: 2$ & $42: 0$ & $7: 0$ & $389: 4$ & $14: 3$ \\
\hline 101:3 & $84: 3$ & $19: 2$ & 408:0 & \\
\hline $102: 2$ & 109:1 & $38: 3$ & $445: 1$ & \\
\hline 122:2 & $127: 0$ & $59: 2$ & $599: 2$ & \\
\hline 164:0 & $136: 1$ & 101:2 & 1189:1 & \\
\hline 173:1 & $158: 2$ & $166: 3$ & $1192: 4$ & \\
\hline 194:2 & $181: 2$ & $176: 2$ & $1196: 2$ & \\
\hline 206:0 & $187: 2$ & $240: 2$ & 1214:0 & \\
\hline 209:2 & $263: 4$ & 280:0 & $1237: 2$ & \\
\hline 216:0 & 269:1 & 291:2 & $1276: 1$ & \\
\hline $218: 2$ & $278: 1$ & 294:3 & $1280: 0$ & \\
\hline 224:2 & $309: 3$ & $420: 0$ & $1316: 1$ & \\
\hline 237:0 & $323: 4$ & $436: 3$ & $1325: 0$ & \\
\hline $242: 2$ & $327: 4$ & & 1344:1 & \\
\hline 275:0 & $367: 0$ & & $1356: 1$ & \\
\hline 285:2 & $377: 1$ & & & \\
\hline 287:2 & 394:0 & & & \\
\hline $305: 3$ & $447: 1$ & & & \\
\hline 333:1 & $471: 2$ & & & \\
\hline $335: 3$ & $481: 2$ & & & \\
\hline 347:0 & $482: 2$ & & & \\
\hline 386:0 & $514: 1$ & & & \\
\hline 387:0 & $540: 2$ & & & \\
\hline 389:3 & $546: 1$ & & & \\
\hline $398: 2$ & $559: 3$ & & & \\
\hline $461: 2$ & $560: 0$ & & & \\
\hline 485:0 & & & & \\
\hline 494:3 & & & & \\
\hline 536:0 & & & & \\
\hline $539: 3$ & & & & \\
\hline $551: 2$ & & & & \\
\hline $563: 3$ & & & & \\
\hline $614: 2$ & & & & \\
\hline
\end{tabular}




\section{List of Characters}

The initial matrix relied on 50 characters, which were revised during this study. The list of characters was exhaustively refined through MorphoBank online matrix, which was adapted to present here. After the last revision, the morphological matrix relies on 33 characters which are list as below.

0. Pigment solubility.

\section{High}

1. Low

Remarks: Although color is not recommended as characters by many phylogenetic studies, the pigment solubility is one easy way to recognize the Onychophora families. This is wide known, once the pigment is lost immediately after fixation in Peripatidae, while the pigment is more durable in Peripatopsidae.

1. Patterns of the dorsal body region.

0. Absent

1. Present

Remarks: Dorsal patterns can be color mosaics, and structures on the body such as modified dorsal papillae and their distributions.

2. Diamonds on dorsal side.

0 . Absent

1. Present (see Chapter 2: Figure 2, E. edwardsii)

3. Color of the diamonds

0. Light (see Chapter 2: Figure 2, E. edwardsii)

1. Dark

4. Head color.

0. Dark

1. White (or white head band)

Remarks: This character was observed in Panama species, although the white band head occurs in some species from Colombia and Brazil such as Peripatus heloisae Carvalho, 1941. 
5. Dorsamedian furrow.

0 . Continuous

1. Discontinuous

Remarks: Some Peripatopsidae species show discontinued dorsamedian furrow, interrupted by dorsal papillae or line interruptions.

6. Accessory teeth on the outer jaw.

0 . Absent

1. Present

7. Number of accessory teeth on the outer jaw.

0.1

1. 2

8. Diastema on the Inner jaw.

0 . Present

1. Absent

9. Accessory teeth on the Inner jaw.
0 . Absent
1. Present

10. Number of accessory teeth on the inner jaw.
0.1
1. 2

11. Distribution of the Primary Papillae.

0 . On all dorsal plicae

1. On alternate dorsal plicae

12. Texture of the scales on the base of the Primary papillae.

0 . Smooth and flat

1. Rugous with furrows

2. Rugous and flat

Remarks: On the rugous and flat state, the scales show ridge on the top, although smooth 
furrows occur as such on states 0 and 1 .

13. Distribution of ranks of scales in the anterior and posterior portions of the distal end of papillae.

0 . Symmetrical

1. Asymmetrical

14. Morphology of the apical piece.

0. Spherical

1. Conical

2. Digitiform

3. Flat

Remarks: The flat state (3) is present only in bidimensional apical piece and recognized through constriction between the two parts of primary papillae.

15. Size of the apical piece.

0 . Bigger than the base and large insertion diameter

1. Slightly smaller than the base and small insertion diameter

2. Smaller than the base and reduced insertion diameter

16. Range of scale ranks on the posterior side of the apical piece.

0.1

1. 2 to 4

2. 5 or more

17. Type of dorsal plicae.

0 . Dorsally anastomosing plicae (circa of 9-14)

1. 12 dorsally non-anastomosing plicae

18. Incomplete plicae.

0 . Present

1. Absent

Remarks: Incomplete plicae never extend close to the insertion of the legs.

19. Foot papillae on the leg prolateral side. 

0.1
1. 2
2. 3

20. Foot papillae on the leg retrolateral side.
0.1
1. 2
2.3

21. Apical papillae on the top of the foot.
0. Absent
1. Present

22. Foot papillae on the top of the foot.
0.1
1. 2

23. Number of spinous pads on the fourth and fifth legs.
0.3
1.4
2. 5

24. Shape of the third spinous pad on the fourth and fifth legs.
0. Complete
1. Two similar fragments
2. Two dissimilar fragments

25. Shape of the fourth spinous pad on the fourth and fifth legs
0 . Complete
1. Fragmented or reduced
2. Two fragments or fissured
3. Thinner (much narrower than the others and fragmented)

26. Shape of the fifth spinous pad on the fourth and fifth legs
0 . Complete 

1. Fragmented or reduced
2. Vestigial
3. Fractioned

27. Position of the nephridial tubercles.

0 . Along the midline on third spinous pad

1. On a retrolateral position of the third spinous pad

2. Discrete papillae between the third and fourth spinous pads

3. On a retrolateral position of the fourth spinous pad

28. Crural papilla.

0 . Absent

1. Present

29. Number of legs with crural papilla (male characteristic).
0.1
1. 2
2.3
3. 4

30. Number of crural papillae per leg.

0.1

1. 2

31. Anal glands.

0. Absent

1. Present

32. Anal glands opening.

0 . Opening present with inconspicuous organ.

1. Present forming a fold

2. Present, appendage-shaped 


\title{
Chapter 3. The taxonomy of Epiperipatus Clark, 1913
}

\section{On taxonomic status of twenty-one species of Epiperipatus Clark, 1913, with descriptions of five new species (Onychophora: Peripatidae)}

\author{
Costa, C. S..$^{*}$, Chagas-JR, A. ${ }^{2}$ AND PINTO-DA-Rocha, R. ${ }^{1}$ \\ 1. Departamento de Zoologia, Instituto de Biociências, Universidade de São Paulo. Rua do Matão- \\ Travessa 14, no 321, Cidade Universitária, São Paulo, SP, Brasil. CEP 05508-090. E-mail: ricrocha@usp.br \\ 2. Departamento de Biologia e Zoologia, Instituto de Biociências, Universidade Federal de Mato Grosso. \\ Avenida Fernando Correa da Costa, 2367, Boa Esperança, CEP-78060-900, Cuiabá, MT, Brasil. E-mail: \\ amazonaschagas@gmail.com. \\ * E-mail: csampaioc@gmail.com
}

\begin{abstract}
As consequence of the recent phylogenetic studies for Epiperipatus, this genus is revisited and its traditional characteristics are examined. Nineteen of twenty-six species are revised based on new specimens or type material. Five new species are here described: Epiperipatus [sp1], Epiperipatus [sp2], Epiperipatus [sp17] (having same type locality: Murici, Alagoas state, Brazil), Epiperipatus [sp16] (type locality: Camacan, Bahia state, Brazil) and Epiperipatus [sp10] (type locality: Breves, Marajó island, Pará state, Brazil). According the suggested acts proposed by Costa et al. (in prep.), here the external morphology of Peripatus bouvieri Fuhrmann, 1913, P. solorazanoi Morera-Brenes \& Monge-Nájera, 2010, Principapillatus hitoyensis Oliveira et al., 2012b and Cerradopatus sucuriuensis Oliveira et al., 2015 is reinvestigated. It was concluded that this species possesses a large number of morphological characters shared with Epiperipatus, such as the distribution of dorsal papillae, spinous pad shape, and number of crural papillae per pregenital leg. Based on our morphological data and in accordance with recent phylogenetic studies for Epiperipatus, P. bouvieri, P. solorzanoi, P. hitoyensis and C. sucuriuensis were included in Epiperipatus.
\end{abstract}

Keywords: Onychophorans, Peripatus, Neotropics, Velvet worms 


\section{INTRODUCTION}

A short background.

There are three important periods in the taxonomy of Onychophora. The first period is marked by ambiguous description and many misinterpretations of morphological characters. Only after the monographies of Sedgwick (1988) and Bouvier (1905, 1907), the Onychophora taxonomy seems to have become more detailed. Undoubtedly, Bouvier was the researcher who concentrated more knowledge about onychophorans, which was disseminated in many works. Basing his work on morphology, Bouvier (1905) created a system of groups in which species of Peripatidae were assembled into four sections named: $\left.1^{\circ}\right) P$. jamaicensis; $\left.2^{\circ}\right) P$. torquatus; $\left.3^{\circ}\right) P$. juliformis; and $\left.4^{\circ}\right) P$. edwardsii. Years later, these sections were erected in the current genera.

The second period is marked by revisions of the groups created by Bouvier. Clark (1913a) was the first author to revise these groups and he created four subgenera for Peripatus. Years later, Peck (1975) perfomed the second revision for onychophorans from the new world, but he did not deeply study the morphology of the genera of Peripatidae. Finally, Read (1988a) considered the characters for Peripatidae genera created by Bouvier to be subjective and promoters of great ambiguity among the current genera, such as Epiperipatus and Peripatus. Hence, Read suggested a way based on images of Scanning Electron Microscopy (SEM), aiming an improvement in good specific characters and better uniformity among Peripatidae genera.

The last period, which comprises the last five years, is marked by the increase of studies using multiple methods in the taxonomy of Peripatidae (Oliveira et al. 2011, 2012a). Especially in Epiperipatus, the phylogenetic and taxonomic knowledge was improved due to the inclusion of SEM images and molecular data.

\section{General introduction}

Onychophora is a phylum poorly known, although the widely applicability of the onychophorans in multiple scientific fields such as Funcional Biology (Hertel et al. 2002), Chemistry (Grahan et al. 2013) and Physics (Concha et al. 2015). The phylum is represented by two extant families with circa of 200 species worldwide. Peripatopsidae has 39 genera, 115 species and Austral distribution, and Peripatidae has 12 genera, 85 species and Septentrional distribution (Monge-Nájera et al. 1995, Murienne et al. 2014, Oliveira et al. 2012a, Oliveira et al. 2012b, Oliveira et al. 2013, Oliveira et al. 2015). Bouvier monographs $(1905,1907)$ are the most important works about 
onychophorans and at where most of velvet worms knowledge was disseminated (Sampaio-Costa et al. 2009). About $90 \%$ of the Peripatidae diversity is concentrated in the two groups created by Bouvier called "andicoles" and "caraïbes". Nowadays, we could refer as "andicoles" group only to Oroperipatus, while the "caraïbes" group to the others Neotropical genera of Peripatidae, which includes Epiperipatus (Bouvier 1905, Read 1988a, Sampaio-Costa et al. 2009). Years later the taxonomy of Peripatidae is still largely based on Bouvier's propositions and few taxonomists gathered focus on "caraïbes" general review. After Bouvier, Read was the unique to revise the genera from the New World, and did it through SEM images (Read 1988a, 1988b). Read (1988a) subdivided five genera (Epiperipatus, Macroperipatus, Oroperipatus, Peripatus and Plicatoperipatus) and three Peripatopsidae species in groups based on the number of scale ranks on the base and apical piece of the primary papillae.

In spite of that, the taxonomy of Peripatidae genera still remains unsolved, especially for Peripatus and Epiperipatus which have unclear definition due to the high variability of the characters (Read 1988a, Sampaio-Costa et al. 2009). Peripatus and Epiperipatus are the most diverse in number of species and have a widespread distribution. As far as we know at present, Epiperipatus is the largest Peripatidae genus, possessing 26 species (excepting the new combinations and new species presented here), having wide distribution in Central America, although there is no record from Mexico and El Salvador, and then spreading through of east South America territories.

The conservative morphology, the high variability of the morphological characters and scarce works attempting to revise the Peripatidae genera resulted in many taxonomical problems. There are many examples of misinterpreted characters that have been wrongly and ambiguously applied. Common errors in morphological examination occur in: 1) dorsal color pattern, 2) disposition of the dorsal papillae distributed on the plicae and 3) the number of legs (Bouvier 1905, Brues 1925, Sampaio-Costa 2009). Generally, not all important diagnostic characters could be studied in a single specimen, and identification as a result was uncertain. This resulted in a number of species showing doubtful geographical distribution, such as Epiperipatus edwardsii (Blanchard, 1847). The latter is the most important species of Epiperipatus, widespread in the Neotropics and covering an area from Panama, Trininad \& Tobago, Venezuela, French Guiana, Suriname, Colombia and Brazil (SampaioCosta et al. 2009, Read 1988b, Oliveira et al. 2012a). This distribution seems unreal if compared to other species of onychophorans, which generally show high endemism and low dispersability.

Three genera of Peripatidae, namely Epiperipatus, Macroperipatus and Peripatus, have been difficult to separate due to the combination of characters with discrete variation among the genera. 
These are shown with the shape of dorsal papillae, the number of scales ranks and the number of pregenital legs with crural papillae. Recently, Costa et al. (in prep.) corroborated the hypothesis of conservative morphology of onychophorans (Peck 1975, Ruhberg 1985, Read 1988a, Gleeson 1996, Reid 1996), and also noticed that the Epiperipatus is paraphyletic and includes three genera. In order to avoid the paraphyletic condition of the latter, they synonymized Principapillatus and Cerradopatus to Epiperapatus and also transferred two species from Peripatus to Epiperipatus. Given this new definition, the Epiperipatus monophyly was supported with unambiguous synapormophies founded in four molecular markers (COI, 12S, 16S and 18S). Moreover, this result showed the ambiguity of the traditional morphology characteristics of Neotropical Peripatidae, and it can be solved in a rearrangement of the current species and a revision of the genus from that region of the world. Here the taxonomy of Epiperipatus was reexamined, based in new and old specimens. This genus seems to be the largest genus of Peripatidae and occupies an area from Belize to Brazil. The review of this genus was based on the traditional morphology characteristics such as color, body patterns, morphology of the dorsal papillae and spinous pad.

\section{Material AND Methods}

In a total we examined 197 specimens. We collected recent specimens of the animals from 2008 to 2014, and they were used in the phylogenetic analysis (see Costa et al. in prep.). The Epiperipatus edwardsii (Blanchard, 1847) types belong to the Muséum National d'Histoire Naturelle (MNHN). We contacted the MNHN requesting exam of the specimens, but, unfortunately, we did not have answer of this institution.

The material examined, which includes the type material, were loaned or studied from the following institutions: British Museum of Natural History (NHM); Museum of Comparative Zoology, Harvard (MCZ or ONYC); Museu Nacional do Rio de Janeiro (MNRJ); Museu de Zoologia da Universidade de São Paulo (MZUSP); Universidad Nacional de Colombia (ICN-ONY); Universidade Federal de Minas Gerais (UFMG); Collection of the Evolution et Diversité Biologique laboratory at Université Toulouse III Paul Sabatier (GF), hereafter only referred to by the acronyms.

For color and body patterns while alive, we photographed the samples with SONY Cybershot DSC-HX1 with built-in flash, or Canon EOS Rebel XS with flash circular cameras. We described the color following the standard names of the 267 Color Centroids of NBS/ISCC Color System (Mundie 1995) and used in descriptions and with codes given between parentheses. 
We obtained the automontage images through a Leica MZ125 Stereomicroscope with built-in Leica DFC 290 camera, Leica Light source CLS100X series 00373 and assembled through of software Leica Application Suite version 3.3.0. We compiled descriptions and dissections with dead specimens through stereomicroscope. The morphological descriptive nomenclature follows the terminology present in Read (1988a), Morera-Brenes \& Monge-Nájera (2010) and Oliveira et al. (2010).

We photographed dorsal integument, jaws and legs (antennae when possible) using SEM. All of tissues were subjected to the steps of clean, critical point and sputter coating. In the cleaning process, the soft parts were washed in a solution of hypochlorite $3 \%$ solution diluted in distilled water. The hard parts (for example the jaws) were cleaned in distilled water and Ethylenediaminetetraacetic acid (EDTA) heat solution in sonicator processor. For critical point, the tissues were dehydrated using an increasing ethanol series: $30 \%, 50 \%, 70 \%, 80 \%, 90 \%$ and $100 \%$.

We used the critical point machines Auto Samdri 815 Series A (Tousimis) and Baltec CPD 030. The sputter coating was completed using the machines Cressington 208HR sputter coater; Denton Desk IV gold sputter model and Balzer SCD 50 sputter coater. Generally an average of 5 to $10 \mathrm{~nm}$ of gold/paladium or platinum/palladium was deposited over the tissues. The navigation for SEM images was done on the microscopes Carl Zeiss EVOs 50, JEOL JSM-6390LV and DSM 940 Zeiss scanning electron. The Backscatter electron detector (BSD) function was used when available on the microscope to avoid the charging effects on the tissues.

Below we present a list of Epiperipatus species. First, we present the valid species names sorted chronologically. Following, species not examined, including nomina dubia. Finally, the new species described in this work. Synonyms are arranged in chronological order.

\section{RESULTS AND DISCUSSION}

Costa et al. (in prep.) showed problems with the morphological support for clades within Peripatidae in their working hypothesis. Among the Peripatidae clades, the "caraibes" group, the largest clade of the result, was not supported by morphology, although internally some clades were supported by morphology. The majority of the characters selected by Costa et al. (in prep.) were from two ways used to identify a Peripatidae genus.

The classical way, offered by Bouvier (1905), focused in quantitave and qualitative characters observed on the external macromorphology. For example Epiperipatus is identified through: (1) 
roundish dorsal papillae insertion, (2) nephridial papillae inserted between the third and fourth spinous pad, on the fourth and fifth pairs of legs and (3) two pregenital legs with crural papillae each. Bouvier explored the internal anatomy such as the length of slime glands and reproductory organs, but they do not seem helpful to recognize the genera.

More recently, Read (1988a) proposed a quantitative way to separate the Neotropical peripatids, counting the range of scale ranks noticed on the basal and apical piece of primary papillae (micromorphology). Groups were suggested according the scalation on the basal or apical pieces. Three major groups were suggested based on apical piece scalation: "(1) with more than three ranks of scales in the apical piece, (2) with three ranks of scales in the apical piece and (3) with less than three ranks of scales in the apical piece" (Read 1988a: 209). In the same way, two groups were suggested based on the number of scales on the base: (1) 15 ranks or more, and (2) an intermediate number between seven to 15 rank, or less than seven. Using Epiperipatus as example, this genus belongs to the second group.

Undoubtfully, these are important tools for the taxonomy of Peripatidae. However, they suffer with low diversity of morphological characters (Costa et al. in prep.), which is evident by the low number of genera supported by morphological characters in working hypothesis of Costa et al. (in prep.). While they could be accurate for distinct species (such as Mesoperipatus tholoni (Bouvier, 1898), and Epiperipatus ohausi), they could sometimes be inefficient, such as in Epiperipatus [sp17] as described below.

Examining the characters chosen by Costa et al. (in prep.), we note that majority of characters (for example presence of incomplete plicae, four spinous pad on the fourth and fifth legs, number of foot papillae on the leg prolateral and retrolateral sides) are shared by the genera of "caraíbes".

Three genera of New World Peripatidae are clearly distinguishable (Heteroperipatus, Oroperipatus and Plicatoperipatus), but the other three genera (Epiperipatus, Peripatus and Speleoperipatus) are weakly distinguishable. For example, the main characteristics of Heteroperipatus are: four foot papillae, three anterior and one posterior, or rarely two anterior and two posterior (see Peck 1975:342); the fourth and fifth pairs of legs present four or five spinous pads; and nephridial papillae between the third and fourth spinous pad on the fourth and fifth pair of legs, or aligned with the fourth spinous pad. Oroperipatus is recognized through: roundish dorsal papillae insertion; four or five spinous pads; and nephridial papillae inserted on the third spinous pad on the fourth and fifth pair of legs. Plicatoperipatus is notably identified through 24 dorsal plicae per segment. Speleoperipatus is unique among Peripatidae genera for being recognized through the blind 
species and depigmented body. However, the external morphology is very similar to observed in the other Neotropical genera as follow: dorsal papillae with roundish insertion; four spinous pads per leg; and nephridial papillae occurring between the third and fourth spinous pad on the fourth and fifth pair of legs. Macroperipatus is recognized through: squared dorsal papillae insertion, exclusive of this genus. However some species of Macroperipatus present squared-like shape of the dorsal papillae insertion (such as M. guianensis Evans, 1909 and M. perrieri Bouvier, 1899) which frequently is hard to recognize. The fourth and fifth pairs of legs present four or five spinous pads. Nephridial papillae are inserted on the third spinous pad on the fourth and fifth pair of legs. Species of Macroperipatus (for example, M. perrieri) can present two pregenital legs bearing crural papillae as such observed among the Epiperipatus species. Peripatus is recognized through: roundish dorsal papillae insertion; and nephridial papillae inserted between the third and fourth spinous pad, on the fourth and fifth pairs of legs. The main characteristics of Epiperipatus are the same of Peripatus, although both are separated by the number of pregenital legs bearing crural papillae.

Epiperipatus, Macroperipatus and Peripatus are still extremely difficult to recognize based on the propositions of Bouvier (1905) and Read (1988a). E. acacioi, E. machadoi and E.ohausi were recently transferred to Epiperipatus (Oliveira et al. 2010, Chagas-Junior \& Costa 2014) due to misinterpretations of the shape of dorsal papillae in the original description. Based on the last phylogenetic study of Epiperipatus (see Costa et al. in prep), it seems to share many morphological characters with Peripatus. For example both genera present the same relationship among nephridial papillae and spinous pad on third and fourth pair of legs and the range of scale ranks on the base and apical piece. Moreover, additional characters were discovered in Epiperipatus since Read (1988a). For example, Sampaio-Costa et al. (2009) found a different range of scale ranks of the primary papillae (See character 15: 2 in Costa et al. (in prep); and here Epiperiatus [sp17] Figure 74) among Epiperipatus species, but they do not discuss this result.

Costa et al. (in prep.) demonstrated the weak morphological support present in Peripatidae. Consequently, Epiperipatus was supported by molecular data and its morphological diagnosis shared characters with Peripatus. These authors recovered the paraphyletic condition of Epiperipatus, because this genus includes species of other genera. To avoid the paraphyly of Epiperipatus, Costa et al. (in prep.) transferred to Epiperipatus the species: Cerradopatus sucuriuensis Oliveira et al., 2015, Principapillatus hitoyensis Oliveira et al., 2012b, Peripatus bouvieri Fuhrmann, 1913 and $P$. solorzanoi Morera-Brenes \& Monge-Nájera, 2010. 
Based on our studies of the species currently considered in Epiperipatus (including E bouvieri, E. solorzanoi, E. hitoyensis and E. sucuriuensis) we can conclude that Epiperipatus possesses a large morphological variation, and many characters shared with Peripatus. For example, after our results Epiperipatus can be inserted on groups (2) and (3). Moreover, in this genus the number of scales on the base of the papillae varies from one to 18 (see E. [sp17] and E. bouvieri).

The diversity of Epiperipatus in Brazil is also expanded. Hence Epiperipatus presents 15 species in this country. We reported Camacan (Bahia state) and Murici (Alagoas state) as two new records of Epiperipatus in Brazil. Most species of Epiperipatus display a limited distribution, the majority restricted to the type-locality and proximities (Oliveira et al 2012a, Chagas-Junior \& Costa 2014). Additionally, some species previously believed to be widely distributed have their distribution revised and reduced here, such as E. brasiliensis, E. edwardsii and E. simoni.

There are many examples of misidentification and morphological misinterpretation on the literature (Bouvier 1905, Brues 1914, Oliveira \& Wieloch 2005, Sampaio-Costa et al. 2009). The emblematic examples are E. edwardsii, E. brasiliensis and E. simoni. Several records in the Neotropics were identified as E. edwardsii and E. simoni, due to the dorsal body papillae distribution, dorsal color pattern, and position of nephridial tubercles similar to the observed in holotypes (Bouvier 1905, Brues 1914, Sampaio-Costa et al. 2009). For E. brasiliensis from Panama, Venezuela, and some records in Brazil the misunderstanding is caused by the absence of incomplete folds exclusive of this species (Brues 1925, Sampaio-Costa et al. 2009).

We reported that it is unlikely that species such as E. edwardsii (Blanchard, 1847) and E. brasiliensis (Bouvier, 1899a) are as widespread as currently understood. There are no rules for onychophorans dispersal range, although they typically do not have huge areas of distribution.

According the arrangement suggested by Costa et al. (in prep.), Epiperipatus becomes the largest Peripatidae genus with thirty-five species, due to four new combinations and another four new species that are presented here. 


\section{Family Peripatidae Evans, 1901}

\section{Genus Epiperipatus Clark, 1913}

Peripatus (Epiperipatus) Clark, 1913a: 17; Cockerell 1913: 87; Scorza: 1953: 783; Froehlich 1968: $163,165-168$

Epiperipatus: Clark 1937:2; Peck 1975: 334; Arnett 1961: 218; Sampaio-Costa et al. 2009: 556; Morera-Brenes and Monge-Nájera 1990: 449, 2010: 1134; Morera-Brenes and León 1986: 278; Röhlig et al. 2010: 229; Chagas-Junior and Costa 2014: 979; Oliveira et al. 2010: 16, 2012a: 7, 2012b: 18, 2015: 227

Principapillatus Oliveira et al., 2012b: 11 (type species Principapillatus hitoyensis Oliveira et al 2012b, by original designation) n. syn.

Cerradopatus Oliveira et al., 2015: 216 (type species Cerradopatus sucuriuensis Oliveira et al. 2015, by original designation) $\mathbf{n}$. syn.

Type-species: Epiperipatus edwardsii (Blanchard, 1847) by original designation

Diagnostic molecular characters: Characterized for unambiguous synapomorphies transformations for $\mathrm{COI}$ in seven positions, for $12 \mathrm{~S}$ in twenty-six positions, for $16 \mathrm{~S}$ in fourteen positions and for $18 \mathrm{~S}$ in one position (See Costa et al. in prep.).

Remarks: Costa et al. (in prep.) observed the non-monophyletic condition of Epiperipatus, due to the presence of Peripatus, Principapillatus and Cerradopatus species nested into the Epiperipatus. Rejecting the paraphyletic condition of Epiperipatus, Costa et al. (in prep.) suggest to transfer C. sucuriuensis, P. bouvieri, P. solorzanoi and P. hitoyensis to Epiperipatus. Hence, Epiperipatus presents stable relationships across the five clades of Neotropical onychophorans, as observed Costa et al. (in prep.) in parsimony analyses, except for the clade where Epiperipatus edwardsii (Blanchard, 1847) is inserted. According the topologies observed in Costa et al. (in prep.), there are three possibilities to delimitations of Epiperipatus at least: 1) only the small clade where $E$. edwardsii was nested, 2) the clade of E. edwardsii and its sister group clades and 3) all clades that result sister group of Oroperipatus. As the authors did not find morphological differences among the "caraíbas" onychophorans, as a result they adopted the third assumption to delimit Epiperipatus. 
Distribution: Central America: Belize (possibly) (sic in Peck 1975:345), Costa Rica, Guatemala, Honduras, Nicaragua and Panama; Antilles: Barbados, Grenada, Jamaica and Puerto Rico; South America: Brazil, Colombia, French Guyana, Guyana, Suriname, Trinidad and Tobago and Venezuela.

\section{1) Epiperipatus edwardsii (Blanchard, 1847)}

(Figures 1 to 6 )

Peripatus edwardsii Blanchard, 1847:140

Peripatus (Epiperipatus) edwardsii: Clark 1913a: 18

Epiperipatus edwardsii: Peck 1975: 345; Read 1988b: 249; Sampaio-Costa et al. 2009: 556; Oliveira et al. 2012a: 10

Examined material: GF180312HC003-06 (collection of the Evolution et Diversité Biologique laboratory at Université Toulouse III Paul Sabatier); 1 ○̊; FRENCH GuIANA, Cayenne, Nouragues Field Station; no further data. Type material not examined.

Diagnosis: Dorsal body background varying on the purple spectrum (Figure 2). Roundish dorsal papillae, and the primary papillae show small range of scale ranks on the base and the apical piece. The apical piece is asymmetrical and spherical with the bristle moved to the posterior region (Figure 4). On the fourth and fifth pair of legs there are four complete spinous pads, although the last one can be broken sometimes (Figure 6).

Redescription: Measurements. The measurements varies from 30 to $35 \mathrm{~mm}$ long, 3.0 to 4.0 $\mathrm{mm}$ wide and $3.0 \mathrm{~mm}$ tall. Color (living specimens). Three color patterns are observed on $E$. edwardsii. In lateral body region the body background is Dark Purplish Gray (234), in top region the color changes to Dark Grayish Reddish Brown (47) with diamonds of Purplish Gray (233) overlapping the dorsomedian furrow which is Light Brownish Gray (63) (Figure 2). The Purplish Gray (233) spreads out of ventral body background, with a median band of Light Grayish Yellowish Brown (79). Legs White (263) and ventral organs Pale Pink (7).

Body description. The dorsomedian furrow and hyaline organs are clearly evident for the whole axis length. There are twelve complete plicae "per segment", two of them are incomplete and seven cross over to the ventral side. The dorsal plicae have a uniform width as described in previously described species. Dorsal papillae distributed on all plicae (Figure 1). Primary papillae are the largest 
dorsal papillae, all of them presenting roundish dome insertion and an asymmetrical spherical apical piece (Figures 1 and 4). The basal piece is bigger than the apical piece and show a range of seven scale ranks, at least, while on the posterior region the apical piece the has a range of three scale ranks (Figure 4). The bristle is moved to the posterior region of the apical piece (Figure 4). The accessory papillae are the smallest, but some of those are as big as the basal piece of a primary papilla (Figure 1). The accessory papillae also present a roundish insertion. In quantity, the accessory papillae are more abundant than the primary papillae on the plicae (Figure 1). Primary papillae frequently separated by accessory papillae, although they can be close together rarely. One to four accessory papillae could be present between two primary papillae. All dorsal papillae are on the plicae, but only (and rarely) the accessory papillae occur over the flanks.

Head. No evident structures or color patterns on the head. The antennae are composed of fortyfour rings. The antennal tip is composed of seven large rings, excluding the disc on the top, and followed by a sequence of slim and large rings until the eighteenth antennal ring, at least. Eyes and frontal organs present in the external ventrolateral region of the antennal base. The length of the frontal organs is equivalent to four fused antennal papillae. The mouth opening is surrounded by one small and unique lobe followed by seven lobes in a decreasing sequence from anterior to posterior sides of the mouth. The jaws dental formula is: 1/1 (Figure 5) and 1/1-2/10. The second accessory tooth seems to be vestigial.

Legs. The number of legs on this species is thirty pairs. On the fourth and fifth pair of legs there are at least four complete spinous pads, although the fourth can be broke sometimes, and without vestige of a fifth spinous pad (Figure 6). The nephridial tubercle occurs on the fourth and the fifth pair of legs, between the third and the fourth spinous pads (Figure 6). This organ is connected at the top with the third spinous pad and free of the fourth spinous pad. There are two pro-lateral (AP) and one retro-lateral (PP) foot papillae on the feet of the fourth and fifth legs (Figure 3). Ventral and preventral organs are evident. The gonopore is located close to the penultimate pair of legs in both sexes.

Sexual dimorphism. Pregenital without crural papillae, although these organs are not described for this species. Inconspicuous anal glands represented only by the two respective pores on the anterior board of anal aperture.

Comments: Epiperipatus edwardsii is the most frequent misidentified species of Epiperipatus and with overestimated distribution. The shape and distribution of the dorsal papillae, dorsal diamond pattern and number of legs are frequently misinterpreted. For example, Ernst (1881) identified fifty- 
three specimens of E. edwardsii from Caracas (the Capital city of Venezuela) based the dorsal color and the number of legs. Bouvier (1905) recognized the same dorsal patterns of E. edwardsii on specimens from Panama, Suriname and four additional Venezuela localities.

Later the distribution range was expanded after Brues (1914) verified the patterns of similar dorsal papillae of E. edwardsii on specimens from Colombia (Cincinnati Coffee Plantation, near Santa Marta). Here it was observed that the diamond patterns are a general feature of most species of Epiperipatus, lacking only in a few species. The molecular data support the species of Epiperipatus (see Costa et al. in prep.), although we did not study all records of E. edwardsii. We will be recognize as E. edwardsii the specimens with molecular similarities in the sequence of the four markers used in phylogenetic study of Epiperipatus (Costa et al. in prep.). Unfortunately, we do not have enough evidence to evaluate the distribution of E. edwardsii, since only one specimen was accessed. It is possible that E. edwardsii only occurs in the type locality or near localities, due to the slow locomotion and strict habitat selection of these animals, which could be strong conditions for a small distribution of species of onychophorans. In consequence, the other records found in literature of $E$. edwardsii such as from Brazil, Costa Rica, Colombia and Venezuela are in fact new species that will not be described here.

The interesting diagnostic features to delimit E. edwardsii are: lighter color of the dorsal middle line, with highlighted diamonds, overlapping a Dark Grayish Purple (229) band; dorsal papillae are over the plicae and never on the folds. Usually the primary papillae are separated by one or two accessory papillae, but they can be close together. The specimens of E. edwardsii from Aripo (Trinidad) identified by Read (1988a), probably constitute another species, closely related to $E$. edwardsii, because the former has darker dorsalmedian furrow line, while the later has lighter dorsalmedian furrow line.

Type locality: French Guyana, Cayenne.

Distribution: French Guyana: Cayenne and adjacency of Nouragues Field Station (Bélizon, Bita, Coco). 


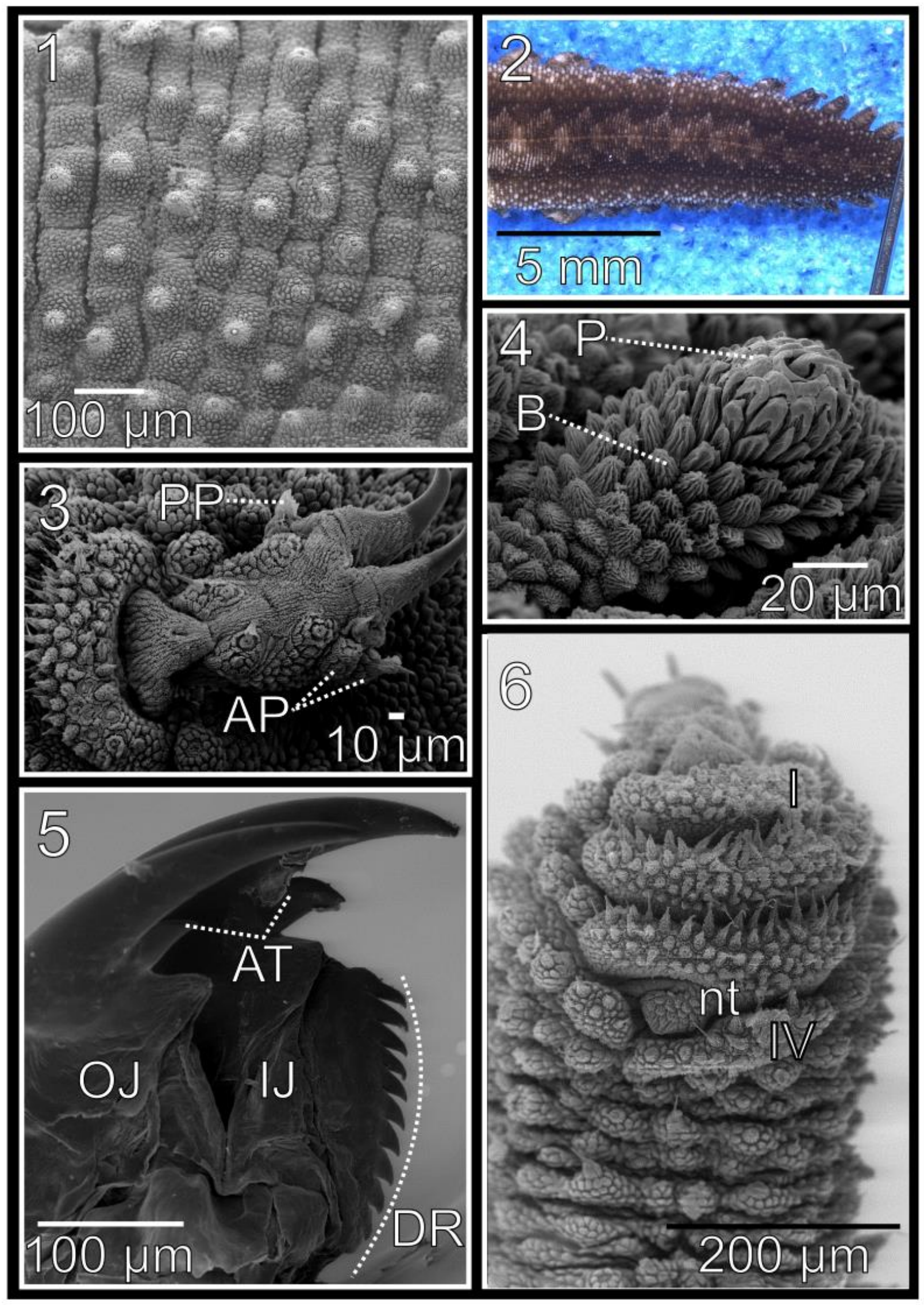


Figures 1 to 6. Epiperipatus edwardsii Blanchard; GF180312HC003-06; Cayenne, Nouragues Field Station. 1. Dorsal papillae arrangement. Scale bar $=100 \mu \mathrm{m}$. 2. Dorsal pattern at middle to posterior region of the dorsal body. Note the diamonds overlapping the dorsomedian furrow. Scale bar $=5 \mathrm{~mm}$. 3. Primary papillae in posterior view. $\mathrm{B}=$ basal part and $\mathrm{P}=$ apical piece. Note that the number and shape of the scales are different on both parts. The count of scales rank is seven on the base and three on the apical piece. Scale bar $=20 \mu \mathrm{m}$. 4. Right Jaw (outer blade in first plan). Scale bar $=100 \mu \mathrm{m}$. 5. Foot ventral view. One retrolateral foot papilla (on the top of the image) and two prolateral foot papillae (on the bottom of the image). Scale bar $=10 \mu \mathrm{m}$. 6. Right fourth leg in ventral view. The Roman numeral showing the first and last spinous pads. Scale bar $=200 \mu \mathrm{m}$. Note the fourth spinous pad broke in two unequal parts. Legend: $\mathrm{B}=$ basal piece, $\mathrm{P}=$ apical piece; $\mathrm{PP}=$ prolateral foot papillae, $\mathrm{AP}=$ retrolateral foot papillae; $\mathrm{OJ}=$ outer blade, $\mathrm{IJ}=$ inner blade, $\mathrm{AT}=$ accessory papillae, $\mathrm{DR}=$ series of denticles; $\mathrm{nt}=$ nephridial tubercle. 


\section{2) Epiperipatus imthurni (Sclater, 1888)}

Peripatus imthurni Sclater, 1888: 344

Peripatus demeraranus Sedgwick, 1888: 476

Peripatus (Epiperipatus) imthurmi: Clark 1913a: 18

Epiperipatus imthurmi: Peck 1975: 345; Read 1988b: 240; Oliveira et al. 2012a: 11

Examined material: NHM 1914.5.1.68-70; 39 ; GUYANA; no data of capture; no data of the collectors; MZUSP 0049; 1 unsexed specimen; GUYANA, Wakapoa, Pomeroom; 8.viii.1959; E. J. Pearce leg. Type material not examined.

General comments: The specimens examined were partially damaged. According to the supporting literature and the exam of NHM and MZUSP specimens, there are no reasons to question the delimitation of this species. The reasons for keeping the status of E. imthurni are: Dorsal integument. Presence of twelve dorsal plicae per segment with uniform width across the dorsal integument and seven of them cross over to the ventral side. Two incomplete plicae per segment at least. Dorsal papillae distributed on all plicae. The dorsal papillae measurement is variable among them, but all of them present a roundish insertion and basal piece in dome. The largest primary papillae apparently occur in alternate plicae. The basal piece is a little bit larger than the apical piece. The accessory papillae seem to be the smallest dorsal papillae and are more abundant than the primary papillae on the plicae. Unfortunately the morphology of the apical piece and structures such as the bristles and scales, were not examined due to the condition of the preserved specimens. On the fourth and the fifth pair of legs there are at least four complete spinous pads and no evidence of a fifth spinous pad. The nephridial tubercle occurs on the fourth and the fifth pair of legs, between the third and the fourth spinous pads. The feet have two prolateral and one retrolateral foot papillae on the fourth and the fifth legs. The recent phylogenetic inferences have suggested a small distribution of the Peripatidae species (Costa et al. in prep.), sometimes restricted to just the type locality. Unfortunately the distribution of E. imthurni is kept in doubt, but its distribution is probably limited to the type locality and nearest localities. This species needs more detailed revision including molecular data to show this.

Type locality: Guyana, Maccasseema on Pomeroom river. 
Distribution: Guyana*: Essequibo, Georgetown, Maccasseema on Pomeroon River, Hoorubea on Demerara River, Dunoon, Wakapa, Issororo (Sclater, 1887, 1888; Bouvier, 1905;

Clark, 1915; Brues 1925; Froehlich, 1962). Trinidad: near to Arima, St Ann's. (Brues 1914; Read 1988b). Colombia: Santa Marta, Cincinnati Coffee Plantation, 3000 ft., seen. (Brues 1914, 1925; Froehlich 1968; Read 1988b), this is probably wrong record (see E. vespucci below). French GuyanaCayenne, Haut Carsevenne (now Alto Rio Calçoene, Brazil). Surinam-Paramaribo. (Bouvier, 1905).

\section{3) Epiperipatus trinidadensis (Sedgwick, 1888)}

Peripatus trinidadensis Sedgwick, 1888: 477

Peripatus trinitatis, Bouvier 1905: 289

Peripatus (Epiperipatus) trinidadensis: Clark 1913a: 18

Epiperipatus trinidadensis: Peck: 1975: 346; Oliveira et al. 2012: 9

Examined material: NHM 1903.11.24.16.1; 1q; TRINIDAD ISLAND; 1903; Dr. P. Reudle leg. Type material not examined.

General comments. The unique specimen examined was a female with 27 pairs of legs. This specimen was the same one examined by Read (1988b), who verified the generic characteristics which approximate this species to Epiperipatus. E. trinitadensis presents dorsal papillae with roundish insertion. The feet on the fourth and the fifth pair of legs have two prolateral and one retrolateral foot papillae. On the same pairs of legs, the nephridial tubercle occurs between the third and fourth spinous pads. The last important revision of E. trinidadensis can be found in Read (1988b), who examined the integument with SEM. According to the SEM images offered in this paper, $E$. trinidadensis is closely related to E. brasiliensis due to the presence of primary papillae with cylindrical apical pieces, but differs to the latter by the presence of incomplete plicae. For more details see Read (1988b) and Oliveira et al. (2012a) for the remarks on taxonomic and nomenclatural problems.

Type locality: Trinidad

Distribution: Trinidad. 


\section{4) Epiperipatus brasiliensis (Bouvier, 1899)}

(Figures 7-14)

Peripatus brasiliensis Bouvier 1899a: 1031

Peripatus sp (Peripatus from Amazons): Moseley 1879: 265

Peripatus Santarem: Sedgwick 1888:484 (invalid name)

Peripatus (Epiperipatus) brasiliensis: Clark 1913a: 18.

Epiperipatus brasiliensis: Peck 1975: 345; Oliveira et al. 2012a: 9

Examined material: NHM; 1 ; ; BRAZIL, Pará, Santarém; no date data; Wickham, purchased from W. H. J. Carter. NHM 96.5.14-25; 2 and 1ठ̋; BRAZIL, Pará, Santarém; no date data; no data of the collectors. MUZSP 0121; 1ठ; BRAZIL; Pará, Santarém, National Forest of Tapajós, km 84; 30.xii.2014; Costa, C.S., Cabra García, J.J., Chirivi, D. and Coronato, A. leg. Type material not examined.

Diagnosis: Dorsal body background reddish brown, no evidence of diamond pattern. The dorsomedian furrow is darker than the body background. It starts in front of the head as a brown spot and between the insertions of the antennae. The dorsal plicae extends until near the legs, with no evidence of incomplete dorsal folds. Primary papillae have a small base, roundish insertion and cylindrical apical piece. The range of pairs of legs on this species varies from Twenty-nine to thirtythree pairs.

Redescription: Measurements. The only specimen examined was a male: MZUSP 0121. 22.1 $\mathrm{mm}$ long, $1.5 \mathrm{~mm}$ wide and $1.2 \mathrm{~mm}$ tall. Color (living specimens). Dorsal body background Grayish Reddish Brown (46) with light dorsal spots (primary papillae) of Light Brown (57) (Figure 7). Lacking a trace of any dorsal pattern with dorsomedian furrow Dark Brown (59) (Figure 7). The dorsomedian furrow starts in front of the head with two spots (like small diamonds) (43) between the insertions of the antennae (Figure 7). The head color is the same as the body background and antennae, Moderate Brown (58). Dorsal side of legs colored the same as the body background. Ventral body background Grayish Red (19) with light papillae Reddish Gray (22). Ventral organs Light Grayish Red (18), spinous pad Light Reddish Brown (42) (Figure 8). 
Body description. The dorsomedian furrow and hyaline organs are clearly evident, with the later present across the extension of the dorsomedian furrow. There are twelve complete plicae per segment, no evidence of incomplete plicae (Figure 9). The dorsal plicae have uniform width across the dorsal integument and seven of them cross over to the ventral side (Figure 9). Dorsal papillae distributed on all plicae. Primary papillae are the largest dorsal papillae, all of them presenting a roundish insertion dome and asymmetrical cylindrical apical piece. Basal piece is a little bit smaller than the apical piece and both show a small range of scale ranks (Figure 12). The former has four scale ranks and the later presents a two anterior and two posterior range of scale rank (Figure 11 and 12). Bristle is a slightly moved to posterior region of the apical piece (Figure 11). Accessory papillae are the smallest and present a roundish insertion also (Figure 10). In quantity, the accessory papillae are more abundant than the primary papillae on the plicae (Figure 10).

No evidence of patterns on the head, but a black diamond is present in frontal position and between the insertions of the antennae. Antennae of E. brasiliensis present forty to forty-five antennal rings. In the specimens examined the number varies around forty-five antennal rings. On the best specimen examined, the top of the antenna presented seven large rings followed by a slim ring, then a sequence of slim and large rings until at least the eighteenth ring. Eyes and frontal organs present in the external ventro-lateral region of the antenna insertion. Frontal organs could be or could not be present. When present, their length is equivalent to four fused antennal papillae.

Head. The mouth opening is surrounded by seven lobes in a decreasing sequence from anterior to posterior sides of the mouth and carrying small spines on the top. The jaws were not observed, but according to the last revision of E. brasiliensis, the dental formula is 1/1 and 1/1/9-11 (Bouvier 1905: 272).

Legs. The intra-specific range of legs is twenty-nine to thirty-two pairs for E. brasiliensis. On the fourth and the fifth pair of legs, in general, there are four complete spinous pads and no evidence of a fifth spinous pad (Figure 14). The nephridial tubercle occurs on the fourth and the fifth pair of legs, between the third and the fourth spinous pads (Figure 14). This organ is connected by the top with the third spinous pad and free of the fourth spinous pad. Two prolateral and one retrolateral foot papillae are on the feet of the fourth and the fifth legs (Figure 13). Ventral and preventral organs are evident, with similar aspects as found in another species (Figure 8). The oldest specimens have had the ventral side dissected, so gonopore and anal opening are not preserved. These structures were only examined on the recent male specimen collected. The gonopore is located close to the 
penultimate pair of legs in both sexes as in all species of Peripatidae, but the opening is not preserved very well.

Sexual dimorphism. Only males presents external dimorphic characteristics. One or two pregenital legs with crural papillae and one crural papilla each. Inconspicuous anal glands represented only by the respective two pores on the anterior board of anal aperture.

Comments: In Brazil, the E. brasiliensis occurs in the states below Santarém, Maranhão and Ceará (Sampaio-Costa et al. 2009: 556), in spite of the distribution seems restricted to Santarém or nearest localities. As found in the results of the Epiperipatus phylogenetic inferences (Costa et al. in prep.), E. brasiliensis only occurs in Santarém, so E. brasiliensis var. vagans is a distinct species, morphologically close to E. brasiliensis as observed Oliveira et al. (2012a). Indeed, E. brasiliensis differs to $E$. vagans through these characteristics: number of antennal rings and body length. $E$. brasiliensis seems a small species and has fewer number of antennal rings comparatively with $\mathrm{E}$. vagans. The specimens identified from Maranhão and Ceará states seem to be a wrong identification. Probably the specimen from Maranhão is an unknowable species, while the specimen from Ceará is clearly a wrong identification (see E. cratensis description below). In the same way the other records found in literature of E. brasiliensis in fact belong to new species not described here.

Type locality: Santarém, Pará state, Brasil.

Distribution: Santarém, Brazil.

\section{5) Epiperipatus ohausi (Bouvier, 1900)}

Peripatus ohausi Bouvier, 1900b: 67; Bouvier 1905: 204

Peripatus (Macroperipatus) ohausi: Clark 1913a: 17

Macroperipatus ohausi: Peck 1975: 347; Sampaio-Costa et al. 2009: 558; Oliveira et al. 2012b:16.

Epiperipatus ohausi: Chagas-Junior and Costa 2014: 979

Type material examined. Museum Hamburg/Germany; 19 syntype (by Hilke Ruhberg personal communication); no data of date and collectors obtained. 

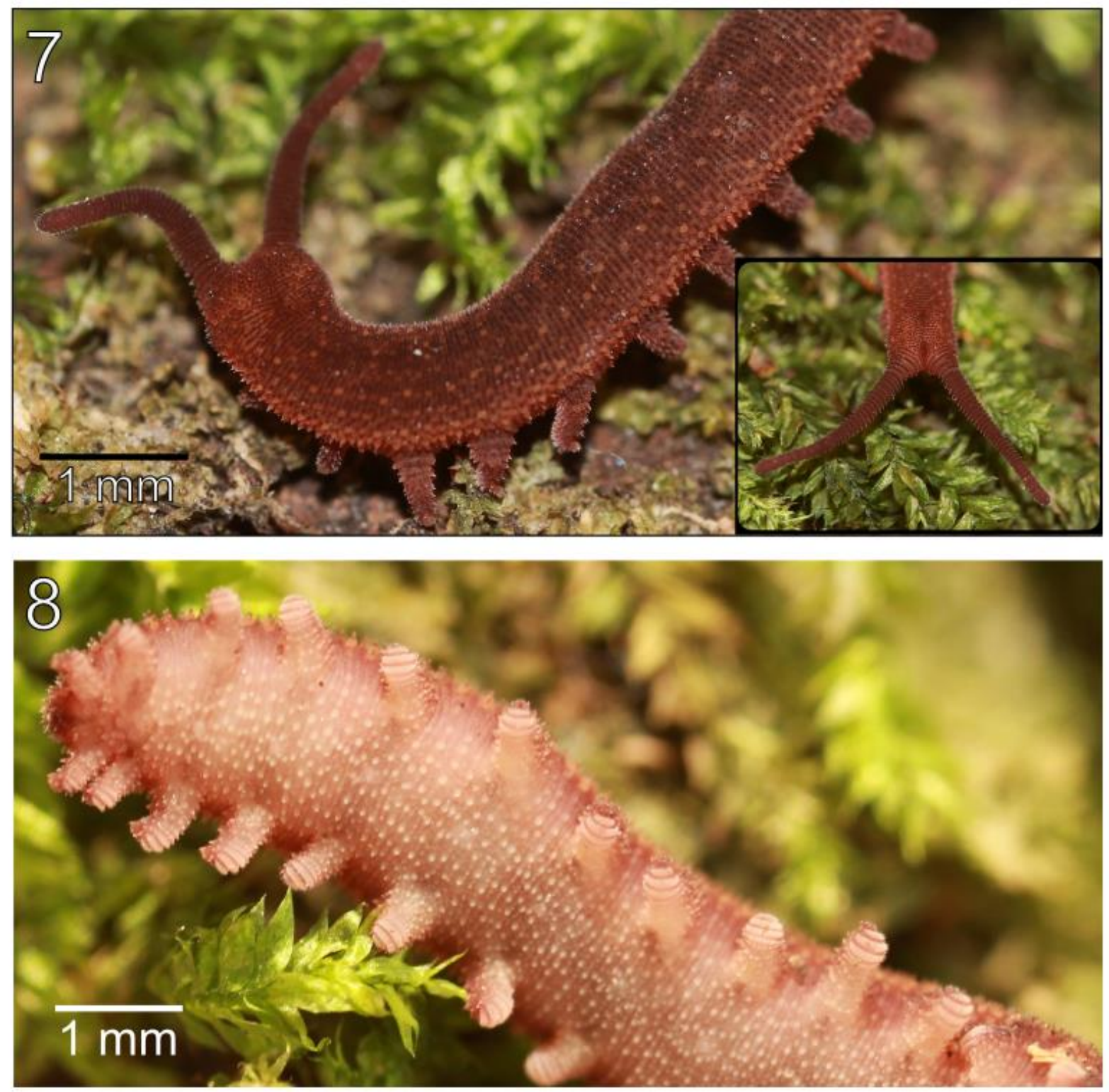

Figures 7 and 8. Epiperipatus brasiliensis Bouvier; MZUSP 0121; Santarém, National Forest of Tapajós. 7. Body background of dorsal side. The small box on the right corner showing the frontal side with the small diamond between the antennae insertion. Scale bar $=1 \mathrm{~mm}$. 8. Body background of ventral side. Scale bar $=1 \mathrm{~mm}$. 


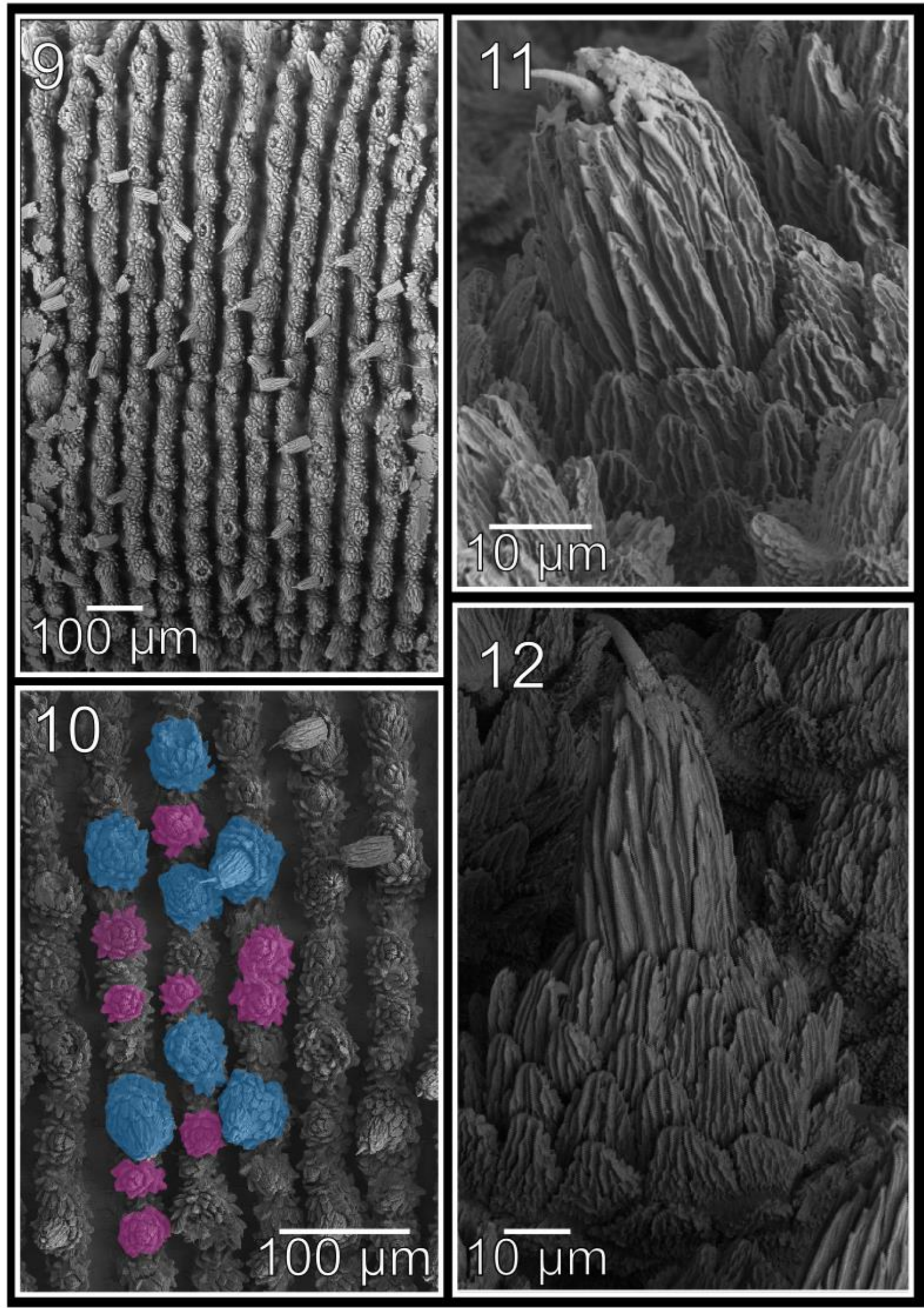


Figures 9 to 12. Epiperipatus brasiliensis Bouvier; MZUSP 0121; Santarém, National Forest of Tapajós. 9. Dorsal plicae arrangement. The image shows a complete region from the dorsal (close to the dorsomediam furrow) to ventral (the leg insertion) sides. Note no incomplete folds. Scale bar = $100 \mu \mathrm{m}$. 10. Detail of the primary papillae (highlighted in blue) and accessory papillae (highlighted in pink). Note the primary papillae are bigger than the accessory papillae. Scale bar $=100 \mu \mathrm{m} .11$. Detail of the apical piece in posterior view. Scale bar $=10 \mu \mathrm{m}$. 12. Apical piece on anterior view. Note the number of scale ranks is the same as the posterior view. Scale bar $=10 \mu \mathrm{m}$. 

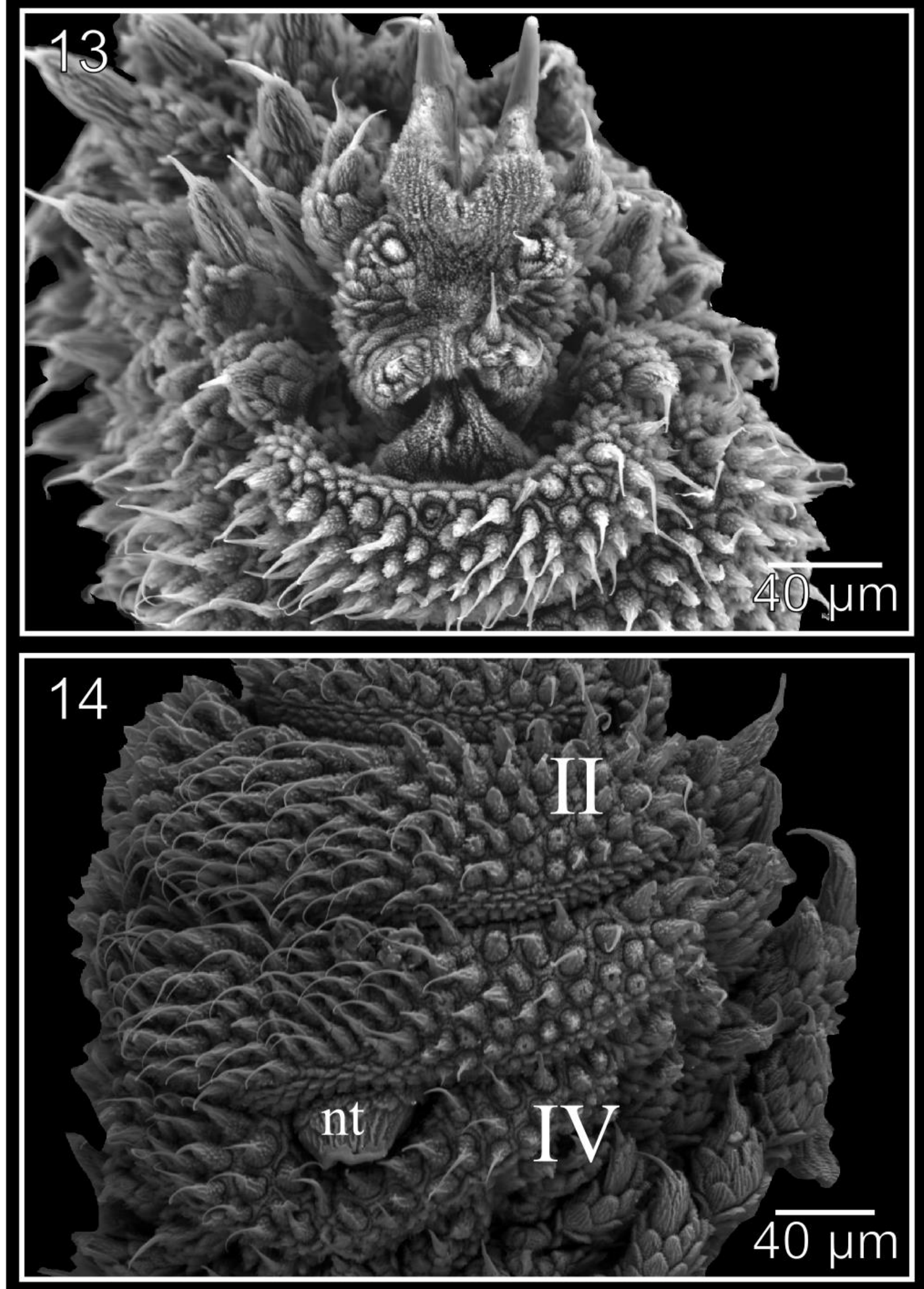
Figures 13 and 14. Epiperipatus brasiliensis Bouvier; MZUSP 0121; Santarém, National Forest of Tapajós. 13. Foot of the fourth left leg with two prolateral foot papilla (left side) and one retrolateral foot papillae (right side). Scale bar $=40 \mu \mathrm{m}$. 14. The same leg found in figure 13, but with detail of the spinous pads. The roman numerals showing the first and last spinous pads. Note the complete fourth spinous pad. Scale bar $=40 \mu \mathrm{m}$. Legend: $\mathrm{nt}=$ nephridial tubercle. 
Examined material. MNRJ 0056; 1q; BRAZIL, Rio de Janeiro, Nova Iguaçu, Reserva Particular do Patrimônio Natural dos Petroleiros; 23.xii.2009; Costa, C.S., Giupponi, A.P.L. leg. MNRJ 0058; 1ठ̊; idem; 11.iii.2010; Costa, C.S., Chagas-Junior, A., Giupponi, A.P.L., Kury, A.B. leg.

Generic comments: This species was transferred to Epiperipatus based on an examination of new samples, from an additional locality, that included SEM images (see Chagas-Junior \& Costa 2014).

Diagnostic molecular characters: According Costa et al. (in prep.), E. ohausi was characterized for unambiguous synapomorphies transformations for COI in ten positions.

Type locality: Brazil, Rio de Janeiro, Petrópolis and Nova Iguaçu, around Parque Nacional da Serra dos Órgãos and related forest near to this national park.

Distribution: Brazil, Rio de Janeiro, Petrópolis and Nova Iguaçu.

\section{6) Epiperipatus isthmicola (Bouvier, 1902)}

(Figures 15 to 23 )

Peripatus nicaraguensis var. isthmicola, Bouvier 1902b: 240

Peripatus (Epiperipatus) isthmicola: Clark 1913a: 18

Epiperipatus isthmicola: Peck 1975: 345; Oliveira et al. 2012a: 11

Examined material: MNRJ 0092; 1 ; COSTA RICA, San José, Barrio Vasconia (near Plaza Viquez); 02.viii.2004; Elodia Sánchez Barrantes leg. MNHN; CosTA RICA, near to San Mateo; no data of capture; Biolley leg. Type material not examined.

Diagnosis: No regular measurement among primary papillae; and the largest dorsal papillae is always represented by primary papillae. The fourth and the fifth pairs of legs have four complete spinous pads. Males with twenty-six pairs of legs and females with twenty-nine to thirty-two pairs. The fourth pair of legs is reduced and exposes the nephridial tubercles on retrolateral region of the spinous pads. 
Redescription: Only one specimen was examined and it was a female. Measurements. $23 \mathrm{~mm}$ long, $2.8 \mathrm{~mm}$ wide and $2.0 \mathrm{~mm}$ tall. Color. There is no information of the color or dorsal pattern of the integument in vivo, but it was possible to verify the presence of the diamond pattern on the dorsal integument.

Body description. Evident dorsomedian furrow and hyaline organs. Twelve plicae per segment with uniform width, two of them are incomplete and seven cross over to the ventral side (Figure 17). Primary papillae distributed across all plicae, large and small primary papillae randomly distributed among the dorsal plicae (Figure 17 to 19). Primary papillae diameter of the basal piece do not exceeds the plicae width. Basal and apical pieces with small range of scales ranks, on the former it varies from three to five scale ranks and on posterior region the later has two (rarely one) scale ranks (Figure 20). Bristle is moved to the posterior region of the apical piece (Figure 20). Accessory papillae are smallest and present a roundish insertion (Figure 18 and 19). In quantity, the accessory papillae are more abundant that the primary papillae on the plicae (Figure 18). The accessory papillae occur on the top of the plicae and on the furrow between two plicae (Figure 18).

Head. No evidence of patterns on the head, but it was possible to observe a trace of dorsal diamonds across the dorsal body region overlapping the dorsomedian furrow. There were forty-six antennal rings with the six largest rings on the top of the antennae, before the first narrow antennal ring (Figure 15). After this followed a sequence of slim and then large rings until the last rings of the antenna (Figure 15). Eyes and frontal organs present in the external ventro-lateral region of the antenna insertion (Figure 16). Frontal organs length is the equivalent of two fused antennal papillae (Figure 16). The mouth opening is surrounded by seven lobes in a decreasing sequence from anterior to posterior sides of the mouth. The jaws dental formula is 1/1 and 1/1/10 (Figure 21 and 22).

Legs. This unique specimen had twenty-nine pair of legs, but the range of legs on E. isthmicola varies around twenty-six to thirty-two pair of legs. Ventral and preventral organs are evident, with similar aspect as found in another species. The genital opening is located close to the penultimate pair of legs, opening in a crux, and usually surrounded by tumescent lobes higher than the ventral integument. 

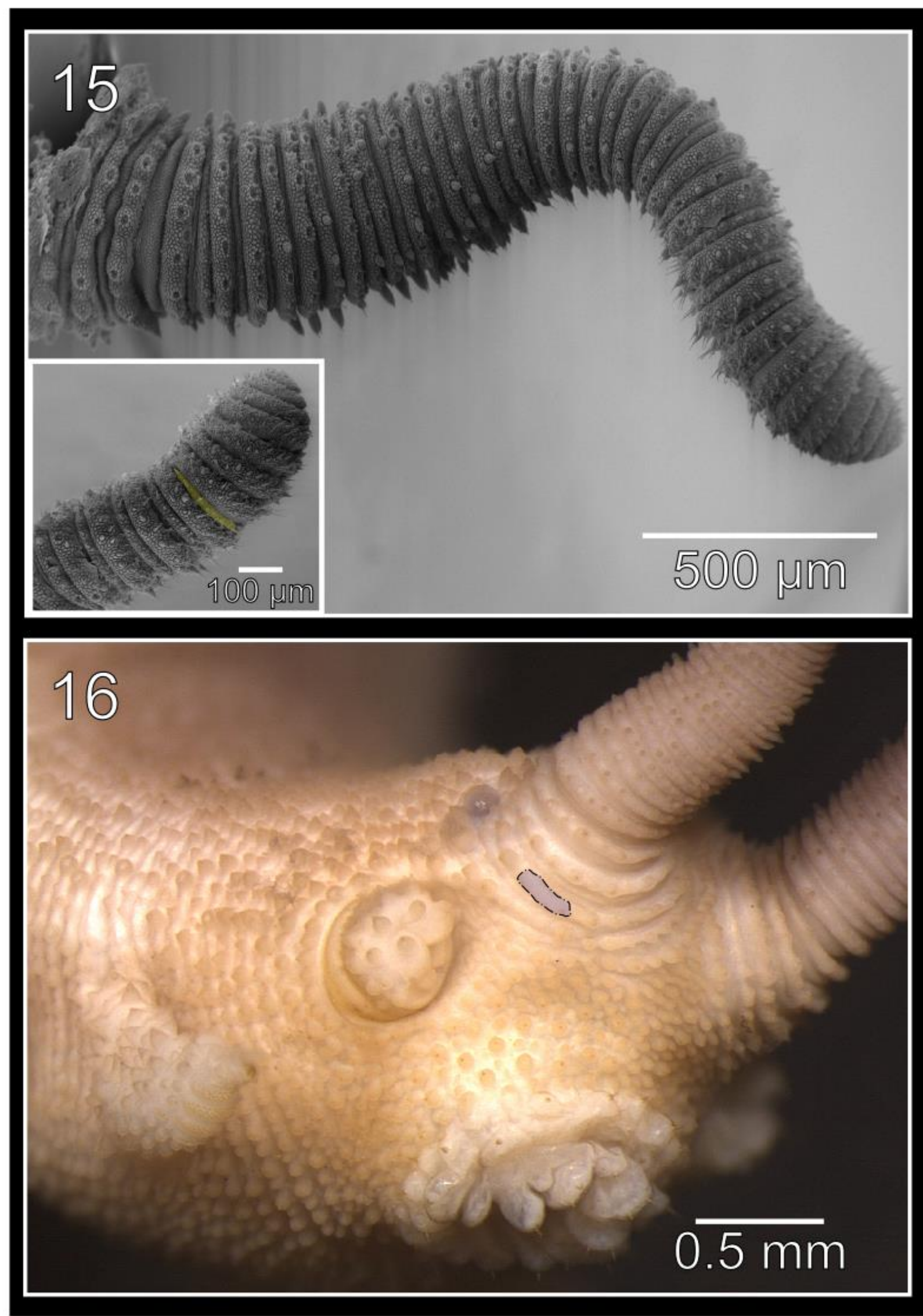
Figures 15 and 16. Epiperipatus isthmicola Bouvier; MNRJ 0092; Costa Rica, San José, Barrio Vasconia. 15. Right antenna. Note the sequence of large and narrow rings after the six rings on the top. In the small square (on corner of the left side) the seventh ring is highlighted in yellow. Scales bar: $500 \mu \mathrm{m}$ for the whole antenna image; $100 \mu \mathrm{m}$ for the small box. 16. The detail of the frontal organ (highlighted with a dash line and purple background) of the right side. Scale bar $=0.5 \mathrm{~mm}$. 


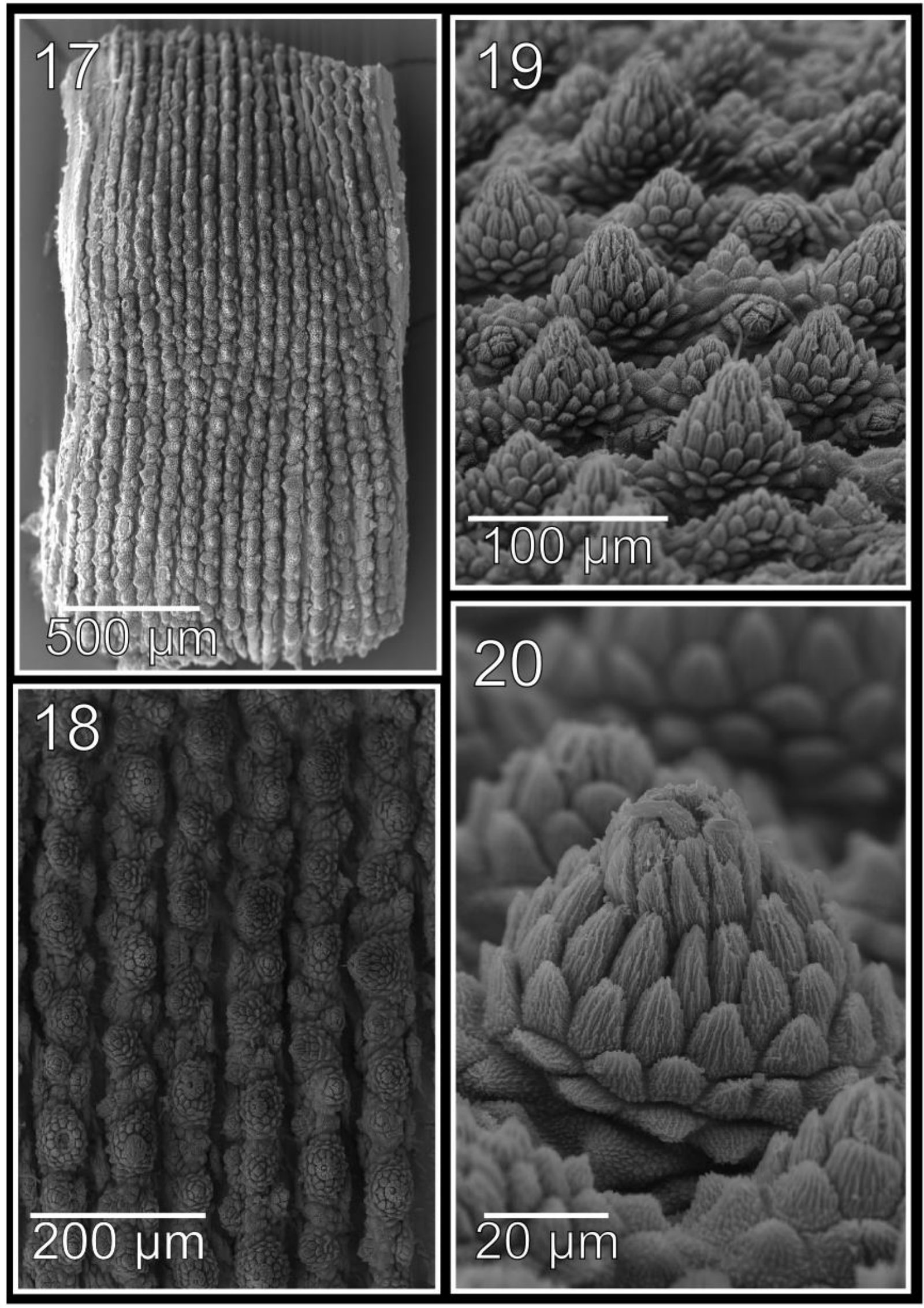


Figures 17 to 20. Epiperipatus isthmicola Bouvier; MNRJ 0092; Costa Rica, San José, Barrio Vasconia. 17. Dorsal plicae arrangement. The image shows a complete region from the dorsomediam furrow (on the top) to the leg insertion (on the bottom). Note the incomplete folds extend to mid body side. Scale bar $=500 \mu \mathrm{m}$. 18. Detail of the dorsal papillae arrangement. Note small accessory papillae on the flanks. Scale bar $=200 \mu \mathrm{m}$. 19. Detail of the apical piece in anterior view. Scale bar $=100$ $\mu \mathrm{m}$. 20. Primary papillae in posterior view. Note the small number of scale ranks on the apical piece. Scale bar $=20 \mu \mathrm{m}$. 


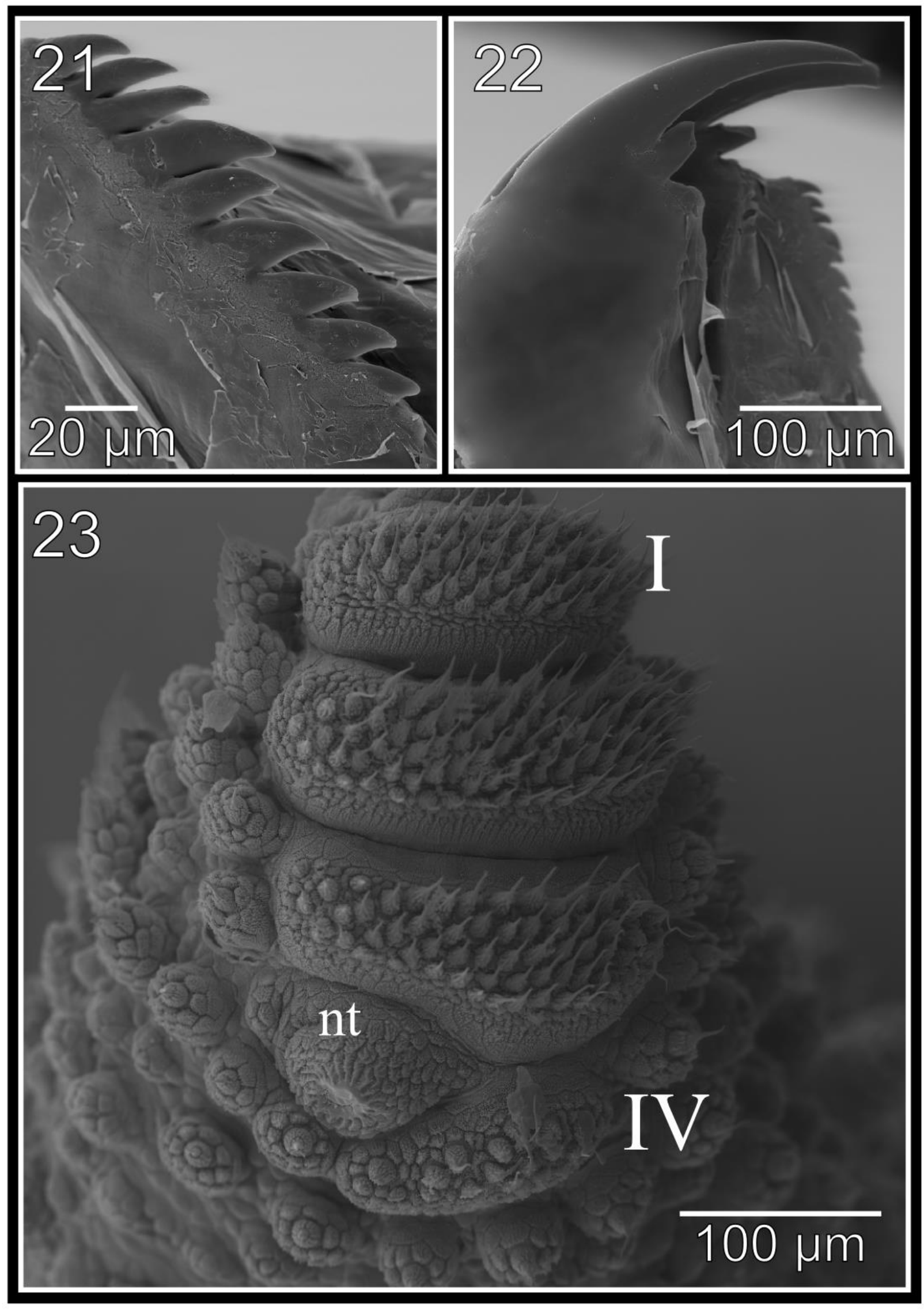


Figures 21 to 23. Epiperipatus isthmicola Bouvier; MNRJ 0092; Costa Rica, San José, Barrio Vasconia. 21 and 22. Detail of the denticles series of the outer blade. Scale bar $=20 \mu \mathrm{m}$. 22. Right Jaw (outer blade in first plane). Scale bar $=100 \mu \mathrm{m}$. 23. Spinous pad of the fifth right leg. The roman numerals show the first and last spinous pads. Note the complete fourth spinous pad reduced and the nephridial tubercles moved to retrolateral side. Scale bar $=100 \mu \mathrm{m}$. Legend: $\mathrm{nt}=$ nephridial tubercle. 
Comments: E. isthmicola is clearly recognized by the morphology of the fourth spinous pad which is shared with Principapillatus hitoyensis Oliveira et al., 2012b (see discussion below) and Epiperipatus nicaraguenis (Bouvier, 1900a). E. isthmicola differs to the last two species by the violaceous body background color "aprés quelques mois dans l'álcool, la femelle type présentait du côté dorsal une teinte violacée brunâtre uniforme" (Bouvier 1905: 330) and the fourth spinous pad morphology

The MNHM specimens examined seems to be wrongly identified. There is clear evidence that the fourth spinous pad morphology which is complete on the specimen from San Mateo while is reduced on the specimen from Barrio Vasconia (Figure 23). If E. isthmicola is marked by the reduced spinous pad on the fourth and the fifth legs, the specimens from San Mateo seem to be an unknown species.

Type locality: Imprecise data.

Distribution: Costa Rica, around San José.

\section{7) Epiperipatus biolleyi (Bouvier, 1902)}

(Figures 24 to 27)

Peripatus biolleyi Bouvier, 1902a: 258.

Peripatus (Epiperipatus) biolleyi: Clark 1913a: 18.

Epiperipatus biolleyi: Peck 1975: 345; Oliveira et al. 2012a: 8

Examined material: MZUSP0012; $1 \uparrow$ and 1ठ̋; CoSTA RICA, San José, Cascajal de Coronado; 01-08.ix.2012; Morera-Brenes, B. leg. Type material not examined.

Diagnosis: Dorsal body background varying on the red spectrum. Dorsal papillae with roundish insertion. Primary papillae asymmetrical with spherical apical piece.

Redescription: Color (living specimens). Dorsal body background Deep Red (13), dorsomedian furrow Strong Brown (55) and antennae Blackish Blue (188). There is no evidence of dorsal diamonds or dorsal pattern. The Pale Purplish Pink (252) spreads out on to the whole ventral body background. Indistinct ventral organs. 
Body description. The dorsomedian furrow and hyaline (sometimes hard to check) organs are clearly evident for the whole length axis. There are twelve complete plicae per segment, two of them are incomplete and seven cross over to the ventral side. The dorsal plicae have uniform width as is described in the previous species. Dorsal papillae distributed by all plicae. Primary papillae are the largest dorsal papillae, all of them presenting a roundish insertion dome and asymmetrical spherical apical piece (Figure 24). The basal piece is bigger than the apical piece and show a range of seven to eleven scale ranks, while in posterior region the apical piece varies with a range of one or three scale ranks (Figure 25 and 26). The bristle is moved to the posterior region of the apical piece (Figure 25). The accessory papillae are the smallest, but some of those as big as the basal piece of a primary papilla (Figure 24). The accessory papillae present a roundish insertion also (Figure 24). In quantity, the accessory papillae are more abundant than the primary papillae on the plicae (Figure 24). Primary papillae are either close together or separated by one to three accessory papilla between the two primary papillae (Figure 24). All dorsal papillae are on the plicae (Figure 24).

Head. No evident structures or patterns on the head. The antennae are composed of forty to forty-three rings. The antennal tip is composed of seven large rings, excluding the disc on the top, and followed by a sequence of slim and large rings until the eighteenth antennal ring, at least. Eyes and frontal organs are present in the external ventrolateral region of the antennal base. The length of the frontal organs is equivalent to four fused antennal papillae, although it can also be absent. The mouth opening is surrounded by one small and unique lobe followed by seven lobes in a decreasing sequence from anterior to posterior sides of the mouth. The jaws dental formula is: $1 / 1-2$ and 1/1/711 (Figure 27).

Legs. Intra-specifically the number of legs varies with from twenty-six to thirty pairs. These numbers vary on males from twenty-six to twenty-eight and females have thirty pair of legs. On the fourth and fifth pair of legs there are four complete spinous pads, without vestige of the fifth spinous pad. The nephridial tubercle occurs on the fourth and the fifth pair of legs, between the third and the fourth spinous pads. This organ is connected by the top with the third spinous pad and free of the fourth spinous pad. There are two pro-lateral and one retro-lateral foot papillae on the feet of the fourth and fifth legs. Ventral and preventral organs are evident. The gonopore is located close to the penultimate pair of legs in both sexes.

Sexual dimorphism. Two pregenital legs present crural papillae and there are two crural papilla each, although the structure can be absent on some specimens. Inconspicuous anal glands represented only by the respective two pores on the anterior board of the anal aperture. 


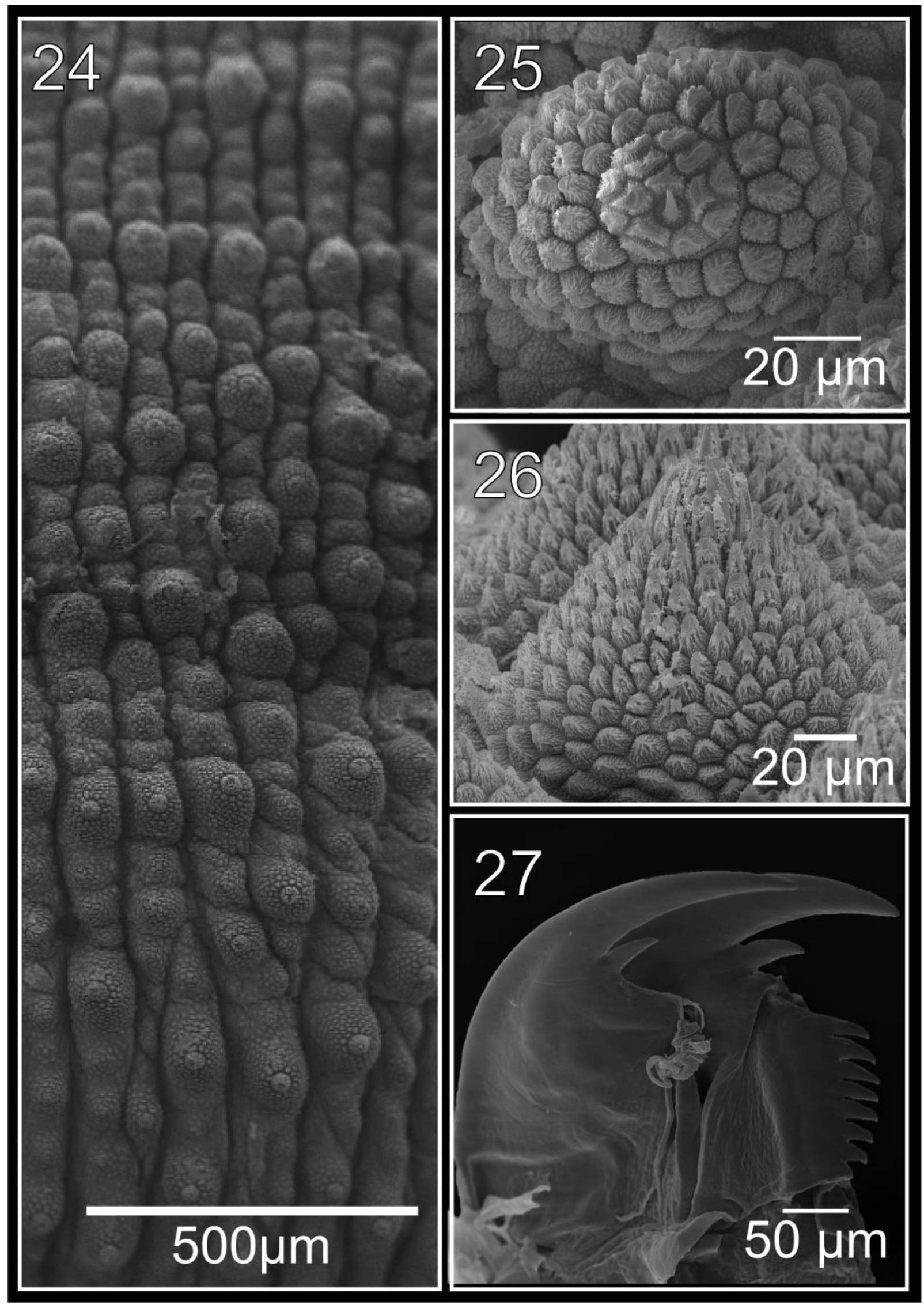


Figures 24 to 27. Epiperipatus biolleyi Bouvier; MZUSP 0012; Costa Rica, San José, Cascajal de Coronado. 24. Dorsal plicae arrangement. The image shows only the dorsal region (dorsomedian furrow on the top) until the mid-lateral region. Note the incomplete folds (the fourth and sixth folds from left to right). Scale bar $=500 \mu \mathrm{m}$. 25. Primary papillae in the top view. Note the bristle moved to posterior region. Scale bar $=20 \mu \mathrm{m}$. 26. Detail of the apical piece in anterior view. Scale bar $=20$ $\mu \mathrm{m} .27$, Right Jaw (outer blade in first plan). 
Comments: E. biolleyi is one the most studied species of Epiperipatus with well-documented morphology and is clearly recognized. For example, E. biolleyi and E. edwardsii differ in the maximum number of accessory papillae between two primary papillae. The former presents one (rarely two) accessory papilla, while the later showing three accessory papillae. The scale ranks on E. biolleyi seems bigger than on E. edwardsii, with the former presenting ten scale ranks on the base and one or two scale ranks on the apical piece. The color pattern is clear distinguishable on these species, because E. biolleyi do not present a dorsal pattern. The scale ranks on E. biolleyi seems bigger than on E. edwardsii, with the former presenting ten scale ranks on the base and one or two scale ranks on the apical piece.

Type locality: Costa Rica, around to San José.

Distribution: Costa Rica, around to San José: Surubres; Cascajal de Coronado.

\section{8) Epiperipatus evansi (Bouvier, 1904)}

Peripatus evansi Bouvier, 1904: 54

Peripatus (Epiperipatus) evansi: Clark 1913a: 18

Epiperipatus evansi: Peck: 1975: 345; Oliveira et al. 2012: 10

Examined material. NHM 1903.11.24.2-3; $1 \uparrow$ and 1 juvenile; GUYANA, Demerara river; no date data; no data of the collectors. Type material not examined.

General comments: It was possible to assess only one of the specimens examined by Bouvier (1905) and it was in bad preservation condition, but it was possible to verify generic characteristics that approximate this species to Epiperipatus. E. evansi presents dorsal papillae with roundish insertion. The feet on the fourth and the fifth pair of legs have two prolateral and one retrolateral foot papillae. On the same pairs of legs, the nephridial tubercle occurs between the third and fourth spinous pads. However, the delimitation of E. evansi is doubtful, because their features easily overlapped with related species. For example, E. imthurni presents similar dorsal papillae distribution and morphology although E. evansi does not present the same small accessory papillae on the dorsal 
furrow between two plicae. Here prudently the name E. evansi is kept, but this species needs a detailed revision.

Type locality: Guyana, Demerara River (See Evans 1903: 158; Bouvier 1905: 286). Oliveira et al. 2012a said the type locality is Maccasseema on Pomerrom River, but this is unlikely, as Evans (1903) only mentioned "on the eastern bank of the Demarara river", although this is a uncertain information.

Distribution: Guyana.

\section{9) Epiperipatus betheli (Cockerell, 1913)}

Peripatus (Epiperipatus) biolleyi var. betheli Cockerell, 1913: 87

Epiperipatus biolleyi var. betheli: Peck: 1975: 349 (misidentification)

Epiperipatus betheli: Oliveira et al. 2012a: 8

Examined material: IZ 83640; 1ठ; GuATEMALA, Holha, El Peten; 19.iii.1922; Loomis, H.F. leg.; 83642 and 83643; 1 q and 1 unsexed; Honduras, San Juan Pueblo; no date data; no data of the collectors. Type material not examined.

Redescription: Measurements. The holotype is a female is $34 \mathrm{~mm}$ long and $4.5 \mathrm{~mm}$ wide. On the specimens here examined, the measurements vary with from 12 to $50 \mathrm{~mm}$ long, 2.3 to $4.0 \mathrm{~mm}$ wide and 2.0 to $2.7 \mathrm{~mm}$ tall. Between the sexes, the single male examined is $12.0 \mathrm{~mm}$ long, $2.3 \mathrm{~mm}$ wide and $2.7 \mathrm{~mm}$ tall, while the female is $50 \mathrm{~mm}$ long, $4.0 \mathrm{~mm}$ long and $2 \mathrm{~mm}$ tall. Color. The color of living species is not clearly known (no living specimens).

Body description. Despite the original description cite "no median dorsal line" (Cockerell 1913: 87), the dorsomedian furrow and hyaline organs are clearly evident for the whole length of the axis on the three specimens examined. The dorsal plicae has a uniform width as described in the previous species descriptions. There are twelve complete plicae per segment, two of them are incomplete and seven cross over to the ventral side. Primary papillae seem the largest dorsal papillae, all of them presenting a roundish insertion dome and an asymmetrical cylindrical apical piece, although Cockerell (1913) described the primary papillae with elongated base with a conical piece. The bristle is moved to the posterior region of the apical piece. The accessory papillae are the smallest, and they 
are more abundant than the primary papillae on the plicae. Primary papillae can be close together or separated, and if separated the number of accessory papillae vary from one to five between two primary papillae.

Head. No evident structures or patterns on the head. The antennae are composed of forty-two to forty-five rings. The antennal tip is composed of six large rings, excluding the disc on the top, and followed by a sequence of slim and large rings until at least the middle of the antenna body. Eyes and frontal organs present in the external ventrolateral region of the antennal base. The length of the frontal organs is equivalent to three or five fused antennal papillae. The mouth seems surrounded by one small and unique lobe followed by seven lobes. Different to the original description, the jaws dental formula on the better preserve specimen is: $1 / 0$ and $1 / 1 / \geq 8$.

Legs. Intra-specifically the number of legs varies from twenty-five to thirty pairs of legs. The male examined has twenty-five pair of legs, while the females seem to have twenty-nine or thirty pairs of legs. On the fourth and fifth pair of legs there are at least four complete spinous pads and rarely a vestigial fifth spinous pad. Sometimes the fourth spinous pad is broken in to inequivalent fragments, although the original description says that the last spinous "pad is well developed and not divided". The nephridial tubercle occurs on the fourth and the fifth pair of legs, between the third and the fourth spinous pads. This organ is connected by the top with the third spinous pad and free from the fourth spinous pad, sometimes a little bit exposed due to the length of the last spinous pad. Two prolateral and one retrolateral foot papillae on the feet of the fourth and fifth legs. The gonopore is located close to the penultimate pair of legs in both.

Sexual dimorphism. On the unique male examined one pregenital legs present crural papillae with one crural papilla each. Inconspicuous anal glands represented by two pores on the anterior board of anal opening.

Comments. On the original description the species was nested in Epiperipatus, based on similarities shared with E. biolleyi. Peck (1975) suggested E. betheli as synonym of Peripatus ruber Fuhrmann, 1913, without offering a discussion about that and a formal synonymization. Oliveira $e t$ al. (2012a) regarded E. betheli as valid name for the specimens from Porto Barrios, Puerto Rico. The position of the nephridial tubercles and the roundish dorsal papillae insertion are enough to keep $E$. betheli nested in Epiperipatus, but the species still requires revision.

Type locality: Guatemala, Puerto Barrios.

Distribution: Puerto Barrios and adjacencies. 


\section{0) Epiperipatus vespuccii Brues, 1914}

Peripatus (Epiperipatus) vespuccii Brues, 1914: 375

Epiperipatus vespucci: Peck 1975: 346; Oliveira et al. 2012a: 13

Type material examined: (Holotype) ONYC-239; 1q; COLOMBIA, 18 miles S of Santa Marta, Cincinnati Plantation (2300 ft. elevation); 15.vii.1913; Ruthven, A. G. and Pearse, A.S. leg, on the Bryant Walker Expedition (University of Michigan), 1913. (Paratype) ONYC-240; 1§; COLOMBIA, 18 miles S of Santa Marta, Cincinnati Plantation (2200 ft. elevation); 21.vii.1913; Ruthven, A. G. and Pearse, A.S. leg, on the Bryant Walker Expedition (University of Michigan), 1913. ONYC-349; 1q; Colombia, Santa Marta; no data of date; Chamberlin, R. V. leg.

Diagnosis: This species varies from 20 to $50 \mathrm{~mm}$ long, 2.0 to $3.0 \mathrm{~mm}$ wide and 1.0 to $4.0 \mathrm{~mm}$ tall. Twelve plicae per segment with uniform width, with seven cross over to the ventral side. There are two incomplete plicae per segment, extending near to halfway between the dorsomedian furrow and the insertions of the legs. The dorsal papillae diameter do not exceeds the plicae width. The largest primary papillae show base and apical piece with similar dimension, although the former is slightly larger than the latter. The primary papillae can be close together, but one to four accessory papillae can be separate two primary papillae.

Redescription: The specimens examined were a male and two females. Measurements. Varying from: 20 to $50 \mathrm{~mm}$ long, 2.0 to $3.0 \mathrm{~mm}$ wide and 1.0 to $4.0 \mathrm{~mm}$ tall. Color. The specimens are totally decolorized on the both body sides and there no signs of dorsal pattern. However in the original description the presence of continuous diamonds and a interrupted dorsomedian furrow pattern were cited for the dorsal region.

Body description. Evident dorsomedian furrow and hyaline organs. Twelve plicae per segment with uniform width, with seven crossing over to the ventral side. There are two incomplete plicae per segment, extending near to halfway between the dorsomedian furrow and the insertions of the legs. Primary papillae distributed on all plicae, with three different sizes all of them randomly distributed among the dorsal plicae. Primary papillae diameter of the basal piece does not exceeds the plicae width. On the largest primary papillae, the base and the apical piece show similar dimensions, although the former is slightly larger than the latter. The bristle is moved to posterior region of the 
apical piece. It was not possible to examine the range of scale ranks of the dorsal papillae. Accessory papillae are the smallest and present a roundish insertion. In quantity, the accessory papillae are more abundant that the primary papillae on the plicae. The accessory papillae occur on the top of the plicae and on the furrow between two plicae. The primary papillae can be close together, it was observed sequences of three primary papillae, or separated by accessory papillae. Among one to four accessory papillae, occur between two primary papillae.

Head. No evidence of patterns on the head. On the antennae there were forty-four to forty-six antennal rings. The top of the antennae is composed by seven large rings follow by the first narrow antennal ring. These rings are followed by a sequence of slim and large rings until last rings of the antenna. Eyes and frontal organs present in the external ventro-lateral region of the antenna insertion. Frontal organs present the length equivalent to three fused antennal papillae. The mouth opening is surrounding (from anterior to posterior side) by one unpaired small lobe and seven pairs of lobes in a decreasing sequence. The jaws dental formula is $1 / 1$ and $1 / 1 / 9$, according the original description.

Legs. The range of pairs of legs on E. vespucci varies from around thirty (the male) to thirtyfour (both females). The fourth and fifth pair of legs, show four complete spinous pads and a vestigial fifth spinous pad. The nephridial tubercle occurs on the fourth and the fifth pair of legs, between the third and the fourth spinous pads, connected only to the third spinous pad. The feet have two prolateral and one retrolateral foot papillae on the feet of the fourth and the fifth pair of legs. Ventral and preventral organs are visible.

Sexual dimorphism. Two pregenital legs present crural papillae one crural papilla each. Inconspicuous anal glands represented only by the respective two pores on the anterior board of anal aperture.

Comments on E. vespucci and E. edwardsii and E. imthurni from Santa Marta, Colombia: Brues (1914) examined specimens from Santa Marta (Colombia) and identified three species ( $E$. edwardsii, E. imthurmi and E. vespucci) occur in sympatry. We examined the "E. edwardsii" specimens examined by Brues (1914). This species differs to E. vespucci only through the number of antennal rings and the size of primary papillae, E. vespucci shows reduced numbers of antennal rings and small apical piece compared to "E. edwarsii". The E. edwardsii from Santa Marta probably is a wrong determination. According to the description of E. edwardsii previously presented (see above), this species shows dorsal papillae with large insertions, which includes the accessory papillae as well, so differing from "E. edwardsii" from Santa Marta. The identification of E. imthurni is very imprecise (see Brues 1914) and based on a questionable combination of characters of the unique 
specimen: presence of dorsal diamonds pattern, and number of legs and position of the nephridial tubercles. It is totally possible that it is a sympatry case at Santa Marta, but it improbable that the occurrence E. edwardsii and E. imthurni are both in the area and it is probably that the specimens of those species belong to two unknown species. Unfortunately, we could not resolve this problem based only in the original specimens examined by Brues (1914).

Type locality: Santa Marta, Colombia.

Distribution: Colombia, Province of Magdalena, Santa Marta.

11) Epiperipatus vagans (Brues, 1925)

(Figures 28 to 31 )

Peripatus (Epiperipatus) brasiliensis var. vagans Brues, 1925: 162

Epiperipatus brasiliensis vagans: Peck 1975: 345

Epiperipatus vagans: Oliveira et al. 2012a: 13

Type material examined: Holotype: IZ 102112; 1q; PANAMA, Barro Colorado Island; 06.ii.1924; Snyder, T. E. leg. Paratypes: IZ 83602; 1 q; PANAMA, San Pablo; no date of data; Lesley,

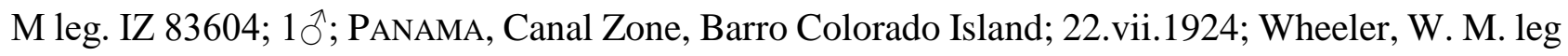
(see Brues 1925). IZ 83629; 1ठ; idem; 26.ii.1924; Snyder, T. E. leg (see Brues 1925). IZ 83606; $1 \delta^{\Uparrow}$; PANAMA, Rio Chinilla; 22.ii.1924; no data of the collectors. IZ 83627; 19; PANAMA, Canal Zone, Las Cascadas; 12.ii.1924; Snyder, T. E. leg. IZ 83628; 1 qand 1ડ̋; PANAMA, Canal Zone, Ft. Sherman; ii.1924 (J. B. Shropshire) (see Brues 1925). IZ 83645; 1 9 ; PANAMA, Rio Tapia; 07.ii.1924; Snyder, T. E. leg.

Examined material: MZUSP 0088; 1 đ̊; PANAMA, Colón, Parque Nacional Soberanía, Sendero El Charco; 01.ii.2014; Pinto-da-Rocha, R and Bernal, J. leg. MZUSP 0101; 1q; idem; 07.ix.2014; Costa, C. S., Cabra García, J.J., Bernal, J., Aguirre, Y. leg. MZUSP 0113 - 0115; 3q; idem; 14.ix.2014; Costa, C. S. and Cabra García, J.J. leg.

Diagnosis: The measurements varies from: 20 to $62 \mathrm{~mm}$ long, 2.5 to $6.0 \mathrm{~mm}$ wide and 1.0 to $4.2 \mathrm{~mm}$ tall. Dorsal body background moderate brown, dorsomedian furrow segment deep brown 
followed by parallel waved and opaque bands. The primary papillae have a conical base and cylindrical apical piece. The range of pairs of legs varies from thirty to thirty-three.

Redescription: Measurements. The species varies in measurements from: 20 to $62 \mathrm{~mm}$ long, 2.5 to $6.0 \mathrm{~mm}$ wide and 1.0 to $4.2 \mathrm{~mm}$ tall. Color (living specimens). The type material specimens are totally decolorized on both body sides and the original description does not mention the color and dorsal pattern for the specimens. However the recently captured specimens show a dorsal body background Moderate Brown (58) (Figure 28). The dorsomedian furrow is Deep Brown (56) and segmented. This segmentation is created by waved and opaque bands of Light Brown (57), which constrict the dorsomedian furrow in each body segment (Figure 28). Random large primary papillae Light Yellowish Brown (76) are present on the whole dorsal side and the antenna are Grayish Reddish Brown (45) (Figure 28). The Brownish Pink (33) spreads through out, the whole, ventral body background. Ventral organs Pinkish White (9) and spinous pad seem Grayish Pink (91).

Body description. The dorsomedian furrow and hyaline organs are evident, although pretty hard to find. Twelve plicae per segment with uniform width, with seven crossing over to the ventral side and no evidence of incomplete plicae. Dorsal papillae with roundish insertion that do not exceeds the plicae width (Figure 29). The primary papillae do not varying among each other and all of them are distributed on the whole dorsal plicae. The primary papillae show a conical base and cylindrical (sometimes conical) apical piece, but they differ in size (Figure 30). The basal piece ranges from five to six scale ranks, while the apical piece are two scale ranks on the anterior and posterior regions (Figure 30). The bristle is symmetrically placed on the apical piece (Figure 30). The primary papillae only occur on top of the plicae, while the accessory papillae, which are smaller than the dorsal papillae, occur on the top of the plicae, the flank of the plicae and the furrows (Figure 29). The primary papillae can be close together or separated by accessory papillae that can occur in numbers of five between two primary papillae, at least (Figure 29).

Head. No evidence of patterns on the head. On the antennae forty-nine to fifty-seven antennal rings. The top of the antennae is composed by five largest rings follow by the first narrow antennal ring. These rings are followed a sequence of slim and large rings until around the twentieth ring. Eyes and frontal organs present in the external ventro-lateral region of the antenna insertion. Frontal organs are present, that in length are equivalent to five fused antennal papillae. The mouth opening is surrounded (from anterior to posterior side) by one unpaired small lobe and seven pairs of lobes in a decreasing sequence. The jaws dental formula is $1 / 1$ and $1 / 1 / \geq 9$. 
Legs. The study of the type material figured out that there were five males and only two were as described by Brues (1925). The range of pairs of legs varies from thirty to thirty-three. For each sexes the number of pairs of leg is twenty-nine to thirty for males, and thirty-two and thirty-three for females. The fourth and the fifth pair of legs, at least, showing four complete spinous pads without the vestige of the fifth spinous pad. The nephridial tubercle occurs on the fourth and the fifth pair of legs, between the third and the fourth spinous pads, connect only to the third spinous pad. The feet have two prolateral and one retrolateral foot papillae on the feet of the fourth and the fifth pair of legs. Ventral and preventral organs are visible.

Sexual dimorphism. The reasonably well preserved males show one or two pregenital legs present with crural papillae, two crural papilla on each, although one male shows only one pregenital leg which carries only one crural papillae. Inconspicuous anal glands represented only by the respective two pores on the anterior board of anal aperture.

Comments: E. vagans is closely related with E. brasiliensis through the number of pairs of legs, absence of incomplete plicae and the morphology of the primary papillae. However, both species differ in number of antennal rings composing the top of the antennae and body measurement. For example, the top of the antennae is composed by five large antennal rings on E. vagans, while $E$. brasiliensis shows seven large rings in the same part of the antennae. Moreover the latter seems a smaller species comparative to E. vagans. Oliveira et al. (2012a) prudently separates E. vagans and E. brasiliensis in to two species based the huge distance between Santarém and Barro Colorado. Here this argument is corroborated with the addition of the morphological differences between these two species.

Type locality: Panama, Canal Zone, Barro Colorado island, Colón, Las Cumbres, Las Cascadas and around to the Panama City.

Distribution: Panama, middle of Panama in the area between Colón and Panama City. 


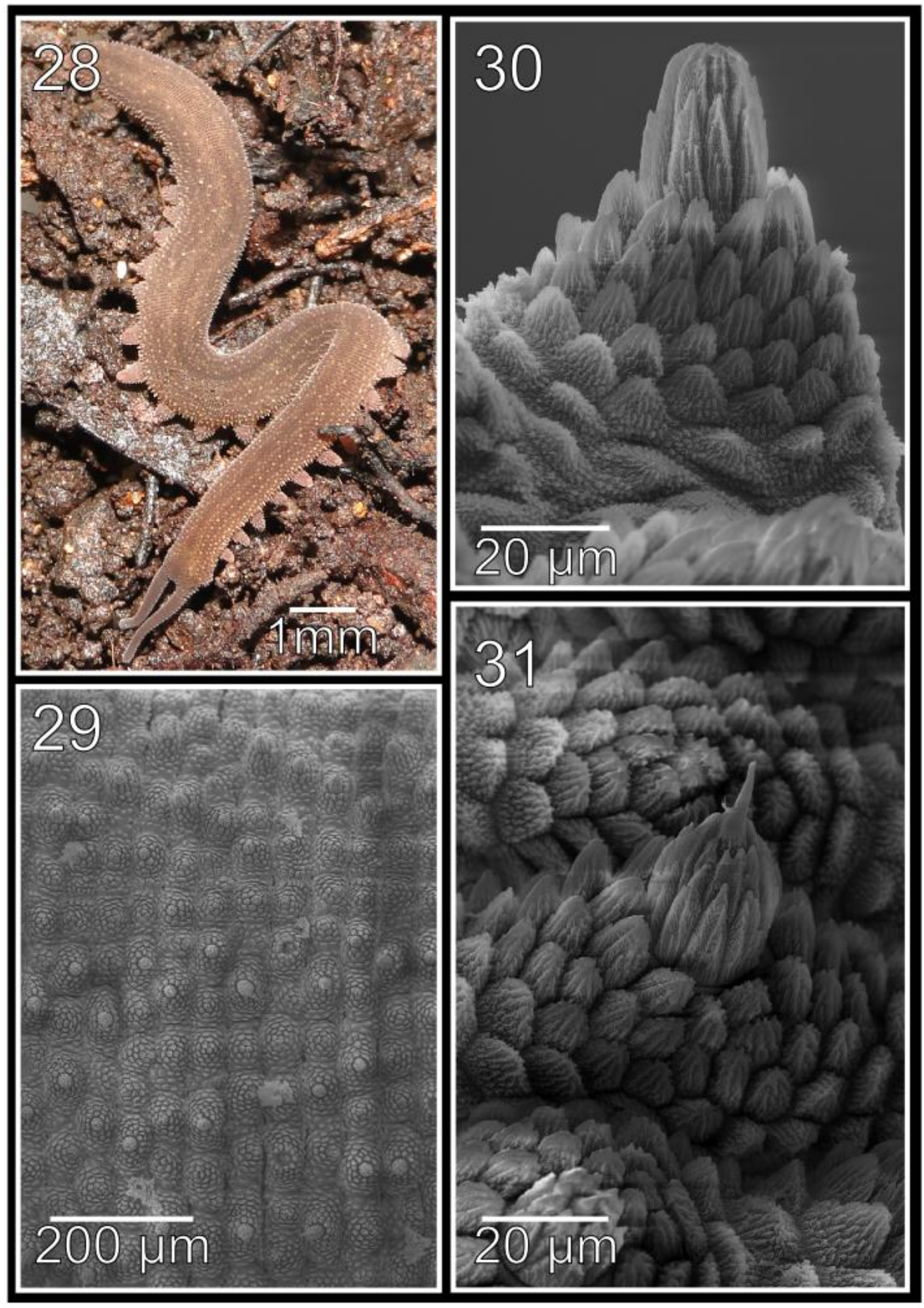


Figures 28 to 31. Epiperipatus vagans Brues; Panama, Colón, Parque Nacional Soberanía, Sendero El Charco. MZUSP 0088. 28. Body background of dorsal side. Scale bar = 1 mm. MZUSP 0101. 29. Dorsal plicae arrangement. The image shows the arrangement near to the dorsomediam furrow. Scale bar $=200 \mu \mathrm{m}$. 30. Primary papilla in anterior view. The bristle is broke on this papilla. Scale bar $=$ $20 \mu \mathrm{m} .31$. Another primary papillae detailing the bristle in posterior view. Scale bar $=20 \mu \mathrm{m}$. 


\title{
12) Epiperipatus acacioi (Marcus \& Marcus, 1955)
}

\author{
(Figures 32 to 39)
}

Peripatus acacioi Marcus \& Marcus, 1955: 189

Peripatus (Macroperipatus) acacioi: Froehlich 1968: 168

Macroperipatus acacioi: Peck 1975: 346; Sampaio-Costa et al. 2009: 557

Epiperipatus acacioi: Oliveira et al. 2010: 21; Oliveira et al. 2012a: 7

Type material examined: (Syntypes) MZUSP 0048; 2, $2 \AA$ and 3 embrions; BRAZIL, Minas Gerais, Ouro Preto; no date data; Acácio Costa leg.

Examined material: MNRJ 0044; 21 , 3 ${ }^{\wedge}$; BRAZIL, Minas Gerais, Ouro Preto, Estação Ecológica do Tripuí; 11.vii.2009; Costa, C. S. and Oliveira, I de S. leg. DZUFMG-ONY0041; $1 \delta^{\lambda}$; BrazIL, Minas Gerais, Ouro Preto, Estação Ecológica do Tripuí; 10.iv.2008; Oliveira, I de S. leg. DZUFMG-ONY0049; 1ठ; idem; 15.v.2008; idem. DZUFMG-ONY 0051, 0052, 0054, 0056, 0158; $5 \AA$; BRAZIL, Minas Gerais, Ouro Preto/Mariana, Parque Estadual do Itacolomi; 05-06.vi.2008; idem. DZUFMG-ONY 0164, 0166, 0167; 3ð; idem; 11-13.x.2008; idem.

Diagnosis: Dorsal body background strong Red. There are twelve plicae per segment, all of them with uniform width. Incomplete plicae present. The primary papillae presents roundish dorsal papillae insertion and spherical apical piece. The accessory papillae is always separated by two primary papillae. There are twenty-five to twenty-eight pair of legs.

Redescription: Measurements. The measurements vary from 13 to $51 \mathrm{~mm}$ long, 2.0 to $5.0 \mathrm{~mm}$ wide and 1.0 to $3.0 \mathrm{~mm}$ tall. Between the sexes, in males it varies from 13 to $30 \mathrm{~mm}$ long, 2.0 to 3.0 $\mathrm{mm}$ wide and 1.0 to $2.0 \mathrm{~mm}$ tall. In females, which are a little bit larger vary with from 18 to $51 \mathrm{~mm}$ long, 2.0 to $5.0 \mathrm{~mm}$ and 1.0 to $3.0 \mathrm{~mm}$ tall. Among the syntypes, the females vary around $30 \mathrm{~mm}$ long and the unique male is $25 \mathrm{~mm}$ long. Color (living specimens). Dorsal body background; Dark Red (16) and a waved band Light Yellowish Pink (28) is extended for the whole body axis (length axis) (Figure 32). Over this band is shown the dorsomedian furrow which is Very Dark Purplish Red (260) and overlapped by diamonds with the same body background color (Figure 32). The color of the Antenna and the head is the same as the body background as well. The Strong Red (12) spread throughout, on the whole ventral body background (Figure 33). 
Body description. The dorsomedian furrow and hyaline organs are clearly evident for the whole of the axis. There are twelve complete plicae per segment, two of them are incomplete and other seven cross over to the ventral side. The dorsal plicae have a uniform width as described in the previously described species. Dorsal papillae distributed on all plicae (Figure 34). Primary papillae are the largest dorsal papillae, all of them presenting a roundish insertion dome and asymmetrical spherical apical piece. The basal piece is bigger than the apical piece, showing a range from seven to nine scale ranks, while on the posterior region the apical piece ranges from two or three scale ranks (Figures 35 and 36). The bristle is moved to the posterior region of the apical piece (Figure 35). Accessory papillae are the smallest and present a roundish insertion as well. In quantity, the accessory papillae are more abundant than the primary papillae on the plicae (Figure 34). Primary papillae are never close together with an accessory papilla between two of them, moreover it is possible to count long lines with more than five accessory papillae between two primary papillae (Figure 34). All dorsal papillae are on the plicae, but only the accessory papillae occur over the flanks.

Head. No evident structures or patterns on the head. The antennae are composed of thirty-four to forty-five rings on both sexes. The antennal tip is composed of seven large rings, excluding the disc on the top, and then followed by a sequence of slim and large rings until close to the last of the antennal rings (Figure 38). Eyes and frontal organs are present in the external ventro-lateral region of the antennal base. The length of the frontal organs is equivalent to two or four fused antennal papillae. The mouth opening is surrounded by one small and unique lobe followed by seven lobes in a decreasing sequence from anterior to posterior sides of the mouth. The jaws dental formula is $1 / 0-$ 1 and 1/1/8-13 (Figure 37).

Legs. Intra-specifically the number of legs varies from twenty-five to twenty-eight pairs. This number varies in males from twenty-five to twenty-six and in females twenty-five to twenty-eight pairs. On the fourth and fifth pair of legs there are at least four complete spinous pads and a vestigial fifth spinous pad could be present rarely on the specimens. The nephridial tubercle occurs on the fourth and the fifth pair of legs, between the third and the fourth spinous pads (Figure 39). This organ is connected by the top with the third spinous pad and free from the fourth spinous pad. Two prolateral and one retrolateral foot papillae in the feet of the fourth and fifth legs. Ventral and preventral organs are evident, with similar aspect as found in another species. The gonopore is located close to the penultimate pair of legs in both sexes as all species of Peripatidae 


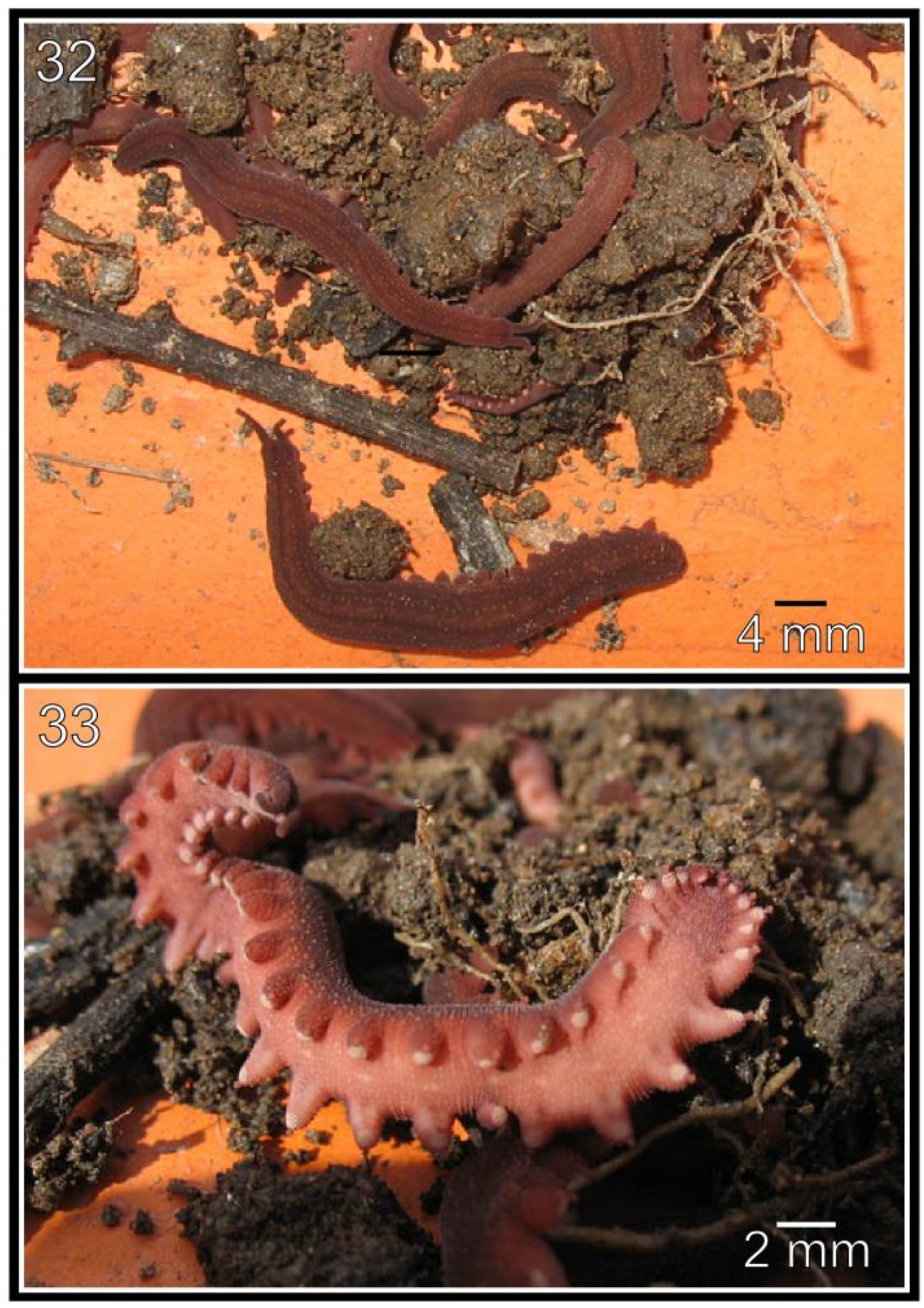


Figures 32 and 33. Epiperipatus acacioi Marcus \& Marcus; MNRJ 0044; Ouro Preto. 32. Body background of dorsal side. Scale bar $=4 \mathrm{~mm}$. 33. Body background of ventral side. Scale bar $=2$ mm. 


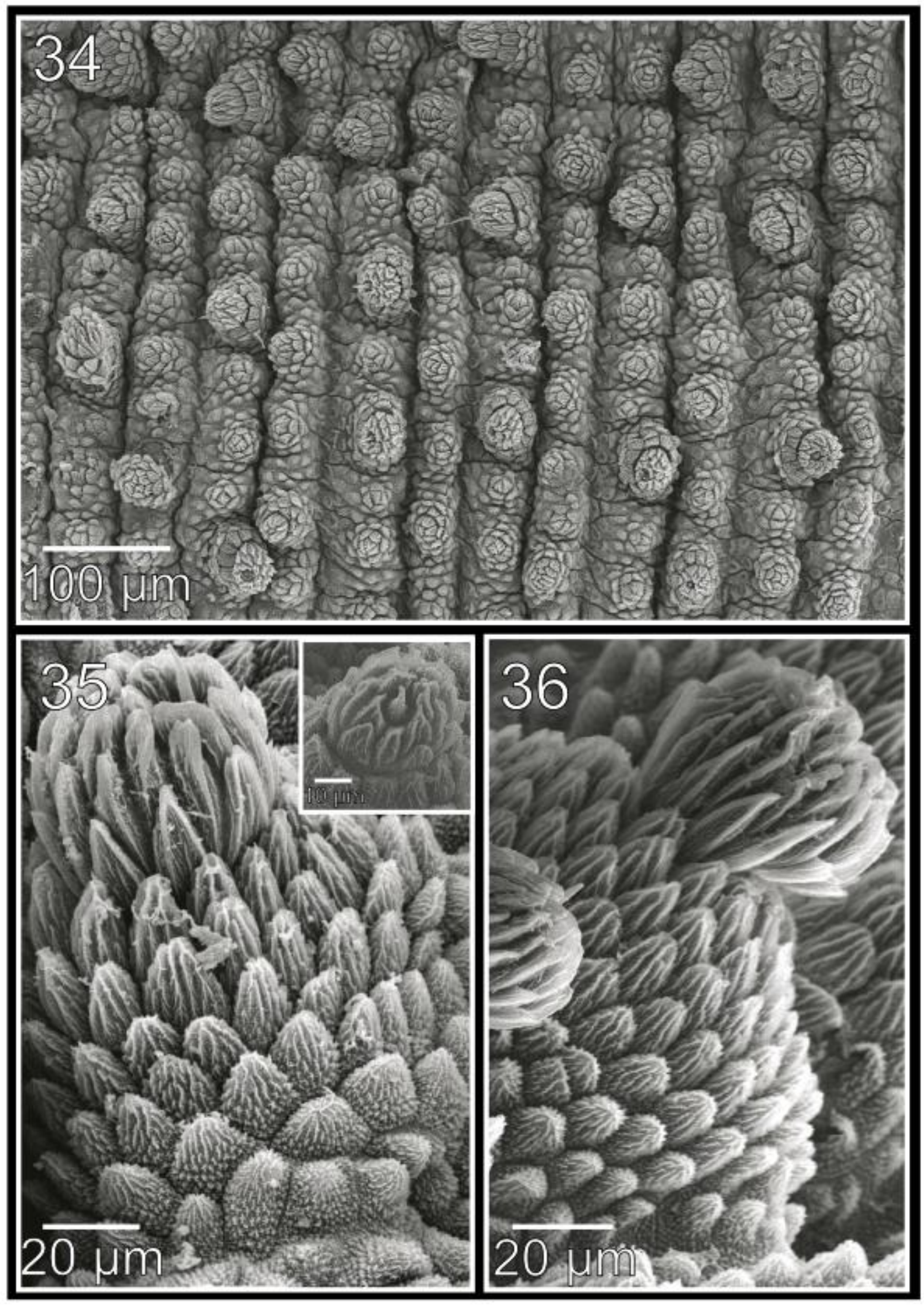


Figures 34 to 36. Epiperipatus acacioi Marcus \& Marcus; MNRJ 0044; Ouro Preto. 34. Dorsal papillae arrangement near to the dorsomedian furrow. Scale bar $=100 \mu \mathrm{m}$. 35. Primary papillae posterior region. Note the small box, detailing another apical piece with one scales in the same view. Scale bar $=20 \mu \mathrm{m}$. 36. Primary papillae in anterior view. Scale bar $=20 \mu \mathrm{m}$. 

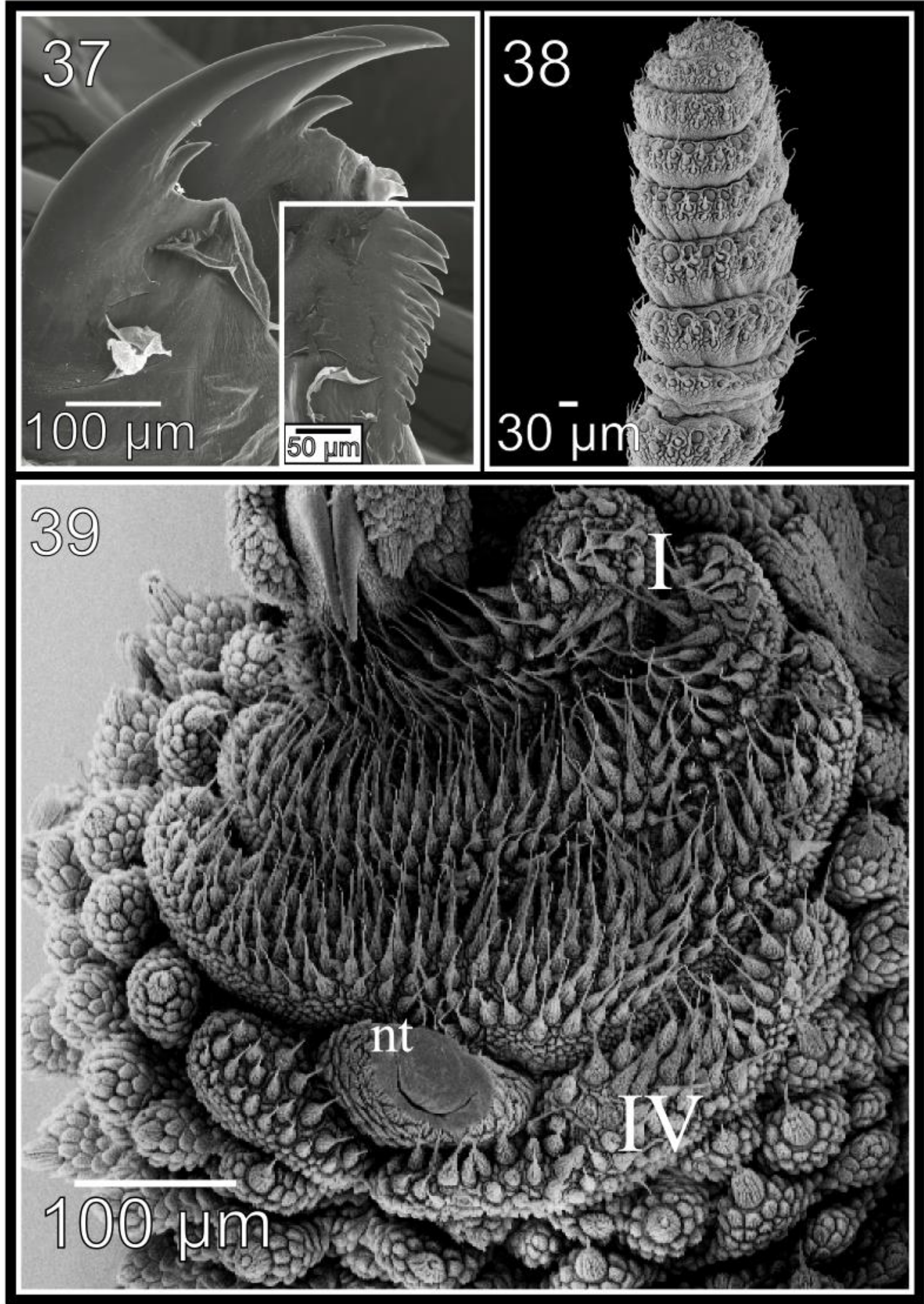
Figures 37 to 39. Epiperipatus acacioi Marcus \& Marcus; MNRJ 0044; Ouro Preto. 37. Right Jaw (outer blade in first plan). Scale bar $=100 \mu \mathrm{m}$. Detail of the denticles series of the outer blade (on the small box). Scale bar $=50 \mu \mathrm{m}$. 38. Right antenna. Note the sequence of seven large follow by narrow ring on the top. Scale bar $=30 \mu \mathrm{m}$. 39. Spinous pad of the fourth right leg. The roman numerals showing the first and last spinous pads. Scale bar $=100 \mu \mathrm{m}$. Legend: $\mathrm{nt}=$ nephridial tubercle. 
Sexual dimorphism. Two or three pregenital legs present crural papillae and there can be one or two crural papillae present on each. The male syntype has two pregenital legs present with crural papilla and one crural papilla on each. Inconspicuous anal glands represented only by the respective two pores on the anterior board of anal aperture.

Comments: Except for the syntypes, the majority of the examined specimens were pretty well preserved due to them being in the collection since 2008 and were pretty well preserved. E. acacioi is one of most studied Peripatidae species such as is E. biolleyi. The species was revised by Oliveira et al (2010) and was transferred to Epiperipatus. The generic characters of E. acacioi do not refute it is current taxonomic position, so this species is one the best representative species of Epiperipatus. Historically, E. acacioi is the most studied among the Epiperipatus species. Recently this species suffered a morphological revision (Oliveira et al. 2010), and frequently is included on phylogenetic studies (Oliveira et al. 2012b, Costa et al. in prep.).

Type locality: Brazil, Minas Gerias, Ouro Preto, Estação Ecológica do Tripuí and Parque Estadual do Itacolomi.

Distribution: Brazil, Minas Gerais, Ouro Preto and Mariana.

13) Epiperipatus barbadensis (Froehlich, 1962)

Peripatus (Peripatus) dominicae barbadensis Froehlich, 1962: 325.

Peripatus barbadensis: Peck 1975: 348.

Epiperipatus barbadensis: Read 1988b: 237; Oliveira et al. 2012a: 8

Type material examined: (Holotype) MZUSP 0044; 19 and 3 juveniles; Barbados, Saint John, Codrington College; 05.viii.1960; Pearce, E.J. leg. (Paratypes) MZUSP 0045; 2 ; idem; 22.ii.1963; idem.

Diagnosis: Species varies from 17 to $32 \mathrm{~mm}$ long. Primary papillae show roundish insertion dome and asymmetrical cylindrical apical piece. Six large rings on the top of the antennae, excluding the disc on the top.

Redescription: Measurements. According to the type material examined, the measurements vary from: 17 to $32 \mathrm{~mm}$ long, 4.0 to $5.0 \mathrm{~mm}$ wide and $2.0 \mathrm{~mm}$ tall. Color (living specimens). 
According to the original description the color is in the spectrum of reddish brown on dorsal side. A narrow brown band, which is in some regions free of dorsal papillae, follows the dorsomedian furrow. There is no information of the ventral side of E. barbadensis.

Body description. The dorsomedian furrow and hyaline organs are barely visible. There are twelve plicae per segment, two of them are incomplete and extending near to halfway between the dorsomedian furrow and the insertions of the legs. Seven of the twelve plicae cross over to the ventral side. The dorsal plicae have a uniform width as described in previously described species. Dorsal papillae distributed on all plicae. Primary papillae are the largest dorsal papillae, all of them presenting a roundish insertion dome and asymmetrical cylindrical apical piece with the basal piece being larger than the apical piece. The bristle is moved to the posterior region of the apical piece. $E$. barbadensis has a basal piece with few scales, to a maximum of eight scale ranks. The apical piece is small, with three scale ranks, according Read (1988b: 239). The accessory papillae present a roundish insertion and are the smallest, but some of those are as big as the basal piece of a primary papilla. In quantity, the accessory papillae are clearly dominant on the plicae. Primary papillae can be close together or separated by one to three accessory papilla between two primary papillae. All dorsal papillae occur on the top of the plicae, but only the accessory papillae occur over the flanks.

Head. No evident structures or patterns on the head. The antennae are composed of forty-three to forty-nine rings on both sexes. The antennal tip seems to be composed of six large rings, excluding the disc on the top, and the first five rings are largest with same width. Eyes and frontal organs present in the external ventrolateral region of the antennal base. The length of the Frontal organs is equivalent to three or four fused antennal papillae. The Jaws dental formula: 1/1 and 1/1/8-9.

Legs. There is no description of males for this species and all specimens examined have thirtyone pairs of legs. On the fourth and fifth pairs of legs there are at least four complete spinous pads with a vestigial fifth spinous pad. The nephridial tubercle occurs on the fourth and the fifth pair of legs, between the third and the fourth spinous pads. This organ is free of the adjacent spinous pads. There are two pro-lateral and one retro-lateral foot papillae on the feet of the fourth and fifth legs. Ventral and preventral organs are evident. The gonopore is located close to the penultimate pair of legs in both.

Comments: Unfortunately, the morphological information of E. barbadensis is provided by old specimens, which result in profoundly bad phylogenetic studies. This species is another example of an endemic distribution in the Caribbean islands. As the other species analyzed here only has old specimens E. barbadensis needs a more detailed revision. 
Type locality: Barbados Island, St. John, Codrington College

Distribution: Barbados Island.

\section{4) Epiperipatus tucupi (Froehich, 1968)}

Peripatus (Epiperipatus) tucupi Froehlich, 1968: 168

Epiperipatus tucupi: Peck 1975: 346; Oliveira et al. 2012a: 14

Type material examined: (Holotype and Paratype) MZUSP 0046; 2q, 1 embrion; Brazil, Pará; 1939; Lima, E. C. leg.

General comments: E. tucupi is only recognized by the two females described by Froehlich (1968). Oliveira et al. 2012a, consider E. tucupi nomina dubia due to the imprecise type locality data. In spite of the description containing imprecise type locality data, there is useful morphology data, which justifies this species belong to Epiperipatus. The types were examined and the analysis corroborates with the original description, so there are no reasons to questioning the delimitation of this species. The relevant features of E. tucupi to redescribe are as follows:

Redescription. The color and dorsal pattern were not examined.

Head. No evident structures or patterns on the head. Forty-three or forty-four antennal rings were counted on the holotypes. The antennal tip is composed of seven large rings, excluding the disc on the top, and followed by a sequence of slim and large rings until at least the eighteenth ring. Eyes and frontal organs present in the external ventrolateral region of the antennal base. The length of the frontal organs is equivalent to five fused antennal papillae. There are twelve dorsal plicae present per segment with uniform width across the dorsal integument and seven of them cross over to the ventral side. There is no evidence of the incomplete dorsal plicae across the segments. Dorsal papillae distributed on all plicae. The dorsal papillae measurement is variable among them, but all of them present a roundish insertion dome and basal piece. The integument had damage, but in areas with reasonable preservation the largest primary papillae apparently occur in all plicae without differentiation among them. The primary papillae present a roundish insertion dome and asymmetrical spherical and well-developed apical piece, and the base and the apical piece showing similar measurement. The bristle is moved to the posterior region of the apical piece. The accessory papillae seems to be the smallest dorsal papillae as the described in the previously species, but there 
is no condition to check if some of those are as big as a primary papilla. In the arrangement of the dorsal papillae, the accessory papillae are more abundant than the primary papillae on the plicae. All dorsal papillae occur on the plicae, but only the accessory papillae can occur over the flanks, but only rarely. The primary papillae can be close together or separated by accessory papillae. Around one to four accessory papillae are between two primary papillae, when they are separated.

Legs. On the fourth and fifth pair of legs there are at least four complete spinous pads and no evidence of a fifth spinous pad. The nephridial tubercle occurs on the fourth and the fifth pair of legs, between the third and the fourth spinous pads, connected only to the third spinous pad. The feet have two prolateral and one retrolateral foot papillae on the fourth and the fifth pair of legs. Ventral and preventral organs are visible.

Sexual dimorphism. This information is unknown to E. tucupi, because only the females are known for this species.

Comments. Based on the morphology of the primary papillae E. tucupi clearly differs from $E$. brasiliensis. The former has spherical and well-developed apical piece, while the latter shows a cylindrical apical piece. Among the Brazilian Epiperipatus that not presenting incomplete plicae, E. tucupi and E. cratensis are more related to each other than with E. brasiliensis, because the spherical apical piece is present on the first two species.

Type locality: (Imprecise data) Brazil, Pará is the type locality presented on the original description, and there are no more records to E. tucupi after its description.

Distribution: Brazil, Pará. Maybe the specimens of E. tucupi were collected close to Belém (the Capital city of Pará state) which was frequently visited by researchers and collectors from southeastern Brazil.

15) Epiperipatus machadoi (Oliveira \& Wieloch, 2005)

(Figures 40 to 47 )

Macroperipatus machadoi Oliveira and Wieloch, 2005: 61

Epiperipatus machadoi: Oliveira et al. 2010: 25; Oliveira et al. 2012a: 12 
Examined material: MNRJ 0043; 6९, 4§; BRAZIL, Minas Gerais, Caratinga, Reserva Particular do Patrimônio Natural Feliciano Miguel Abdala; 09-13.iv.2009; Costa, C.S., Oliveira, I. de S., Queirós, F.N.S. leg.; MNRJ 0048; 4오 2ð; idem; 09.viii.2009: Costa, C. S, leg. DZUFMGONY 0002; $1 \delta^{\jmath}$; BRAZIL, Minas Gerais, Ipanema, Reserva Particular do Patrimônio Natural Feliciano Miguel Abdala; 21.xii.2001; Silva Junior, J.C. leg. DZUFMG-ONY 0069; 1§̊; BRAZIL, Ipanema, Reserva Particular do Patrimônio Natural Feliciano Miguel Abdala; 27.vii.2000; Silva Junior, J.C. leg. Type material not examined.

Diagnosis: The measurements varies from 20 to $66 \mathrm{~mm}$ long, 2.0 to $5.0 \mathrm{~mm}$ wide and 1.0 to $3.0 \mathrm{~mm}$ tall. Dorsal body background is Strong Brown with unclear irregular circles overlapping the dorsomedian furrow. On this species the number of legs varies from twenty-seven to thirty-two. The inner blade of the jaw presents two accessory teeth and the second one is vestigial normally.

Redescription: Measurements. The measurements vary from 20 to $66 \mathrm{~mm}$ long, 2.0 to $5.0 \mathrm{~mm}$ wide and 1.0 to $3.0 \mathrm{~mm}$ tall. Between the sexes, in males it varies from 20 to $35 \mathrm{~mm}$ long, 2.0 to 3.0 $\mathrm{mm}$ wide and 1.0 to $2.0 \mathrm{~mm}$ tall. In females, which are a little bit larger vary from 26 to $66 \mathrm{~mm}$ long, 2.0 to $5.0 \mathrm{~mm}$ and 1.0 to $3.0 \mathrm{~mm}$ tall. The holotype, a female, is $30 \mathrm{~mm}$ long, $3.5 \mathrm{~mm}$ wide and 2.3 mm tall. Color (living specimens). Dorsal body background; Strong Yellowish Brown (74) with a waved band of Brilliant Orange Yellow (67) extending for the whole large body axis (length axis) (Figure 40). Over this band is the narrow dorsomedian furrow that is Very Dark Purplish Red (260) overlapped by unclear "circles" with the same color as the body background. The Antenna and the head are Dark Purple (224). Moderate Yellowish Brown (77) spreads out on the whole ventral body background (Figure 41).

Body description. The dorsomedian furrow and hyaline organs are clearly evident for the whole length of the axis. There are twelve complete plicae per segment, two of them are incomplete and other seven cross over to the ventral side. The dorsal plicae have a uniform width, as described in the previously described species (Figure 42). Dorsal papillae distributed on all plicae (Figure 42). Primary papillae are the largest dorsal papillae, all of them presenting a roundish insertion dome and asymmetrical spherical apical piece (Figure 43 and 44). The basal piece is bigger than the apical piece, showing a range from five to eight scale ranks, while in the posterior region the apical piece range varies from two to three scale ranks (Figure 44). The bristle is moved to the posterior region of the apical piece (Figure 44). The accessory papillae are the smallest, but some of those are as big as the basal piece of a primary papilla. The accessory papillae present a roundish insertion also. In quantity, the accessory papillae are more abundant than the primary papillae on the plicae. Primary 
papillae never close together and have one accessory papilla between two of them, accessory papillae are in small sequences up to four papillae (Figure 42). One to four accessory papillae could be present between two primary papillae. All dorsal papillae are on the plicae, but only the accessory papillae occur over the flanks, and rarely (Figure 42).

Head. No evident structures or patterns on the head. The antennae are composed of from thirtyeight to forty-five rings in both sexes. The antennal tip is composed of seven large rings, excluding the disc on the top, and followed by a sequence of slim and large rings until the eighteenth antennal ring, at least. Eyes and frontal organs present in the external ventro-lateral region of the antennal base. The length of the frontal organs is equivalent to four fused antennal papillae. The mouth opening is surrounded by one small and unique lobe followed by seven lobes in a decreasing sequence from anterior to posterior sides of the mouth. In the original description there is no data about the jaws. The holotype was not examined, but the species dental formula is: 1/1-2 and 1/1-2/9-11 (Figure 45 and 46). The second accessory tooth is vestigial.

Legs. Intra-specifically the number of legs varies from twenty-seven to thirty-two pairs. This number varies with in males from twenty-seven to twenty-nine and in females from twenty-eight to thirty-two. On the fourth and fifth pairs of legs there are at least four complete spinous pads and rarely a vestigial fifth spinous pad (Figure 47). The nephridial tubercle occurs on the fourth and the fifth pair of legs, between the third and the fourth spinous pads. This organ is connected by the top with the third spinous pad and free of the fourth spinous pad. There are two prolateral and one retrolateral foot papillae on the feet of the fourth and fifth pairs legs. Ventral and preventral organs are evident. The gonopore is located close to the penultimate pair of legs in both.

Sexual dimorphism. Two or three pregenital legs present crural papillae and one crural papilla each. Inconspicuous anal glands represented only by the respective two pores on the anterior board of anal aperture.

Comments: E. machadoi, as other species from Minas Gerais, presents a good sampling due to the easy access to the type locality. This species is clearly recognized due to the primary papillae morphology with a blow up basal piece and cylindrical apical piece. Moreover on the color pattern the diamonds are changed into circles. The restricted distribution of E. machadoi is a good example of an endemic species of Epiperipatus.

Type locality: Brazil, Minas Gerais, Caratinga, RPPN Feliciano Miguel Abdala.

Distribution: Brazil, Minas Gerais, Caratinga. 

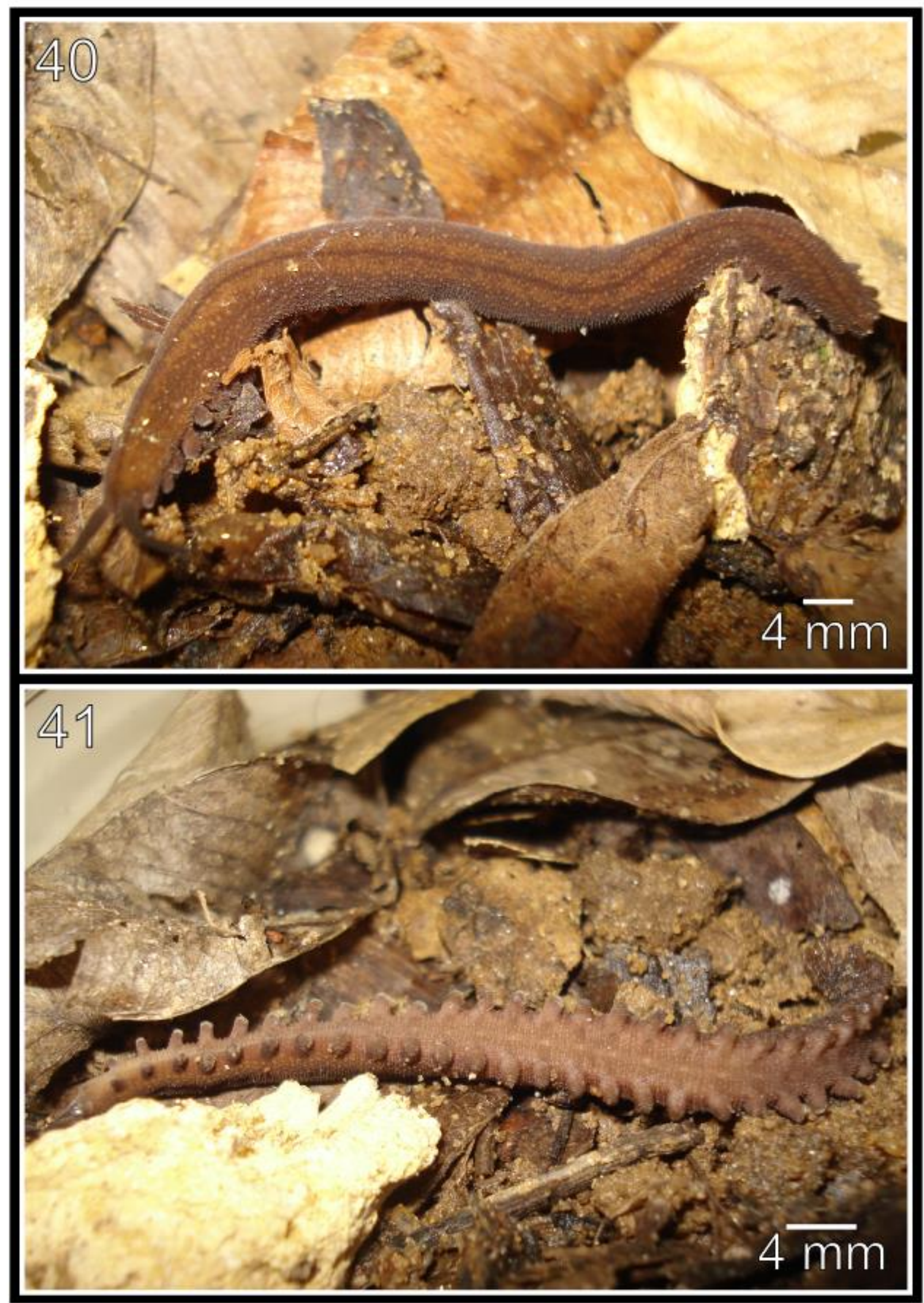
Figures 40 and 41. Epiperipatus machadoi Oliveira and Wieloch; MZUSP 0043; Caratinga. 40. Body background of dorsal side. Scale bar $=4 \mathrm{~mm}$. 41. Body background of ventral side. Scale bar $=4 \mathrm{~mm}$. 


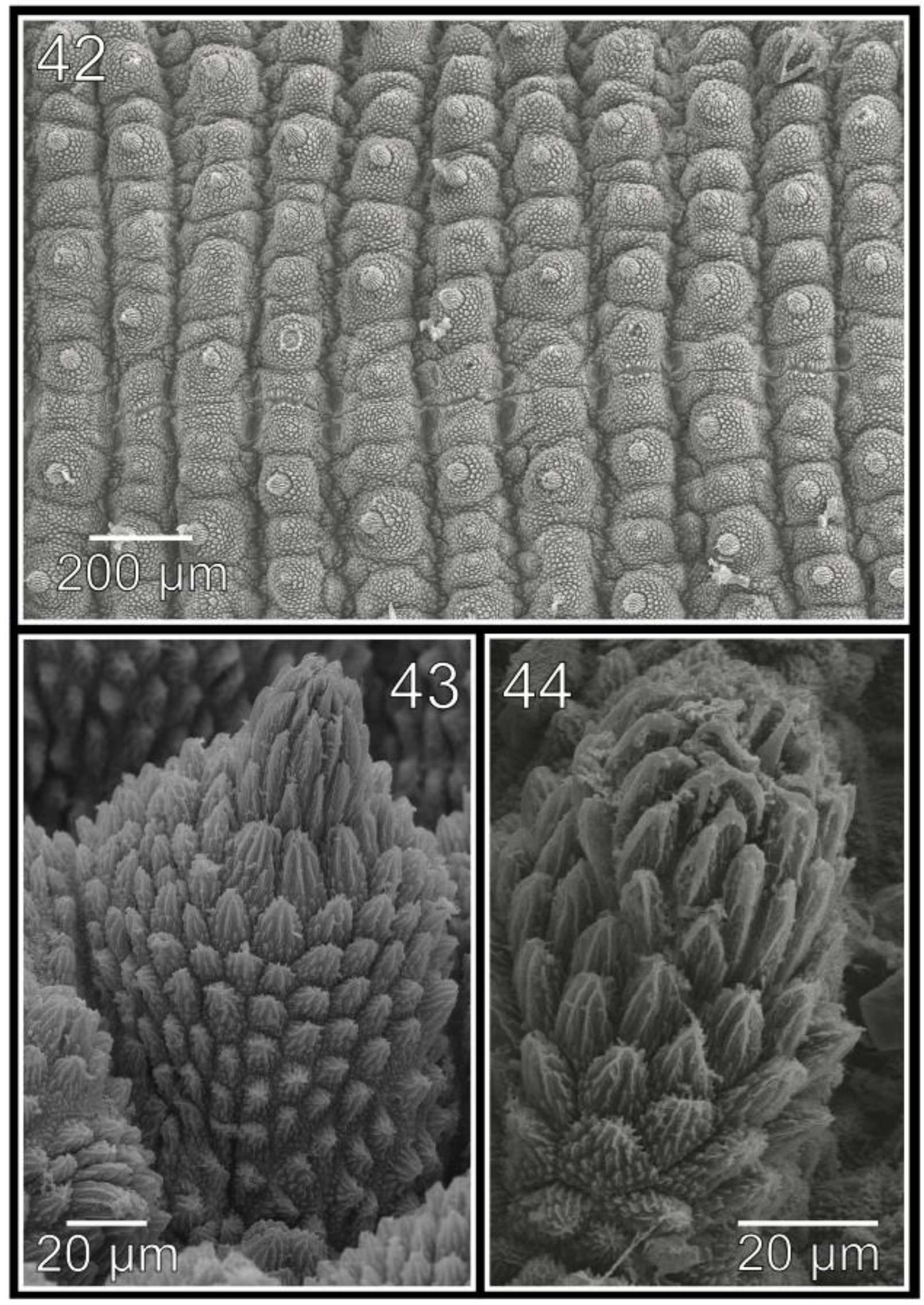


Figures 42 to 44. Epiperipatus machadoi Oliveira and Wieloch; MZUSP 0043; Caratinga. 42. Dorsal papillae arrangement around the dorsomediam furrow (in the middle of image). Scale bar $=200 \mu \mathrm{m}$. 43. Primary papillae shape (posterior view). Note the elongate apical piece and the large number of rank of scales on the base. Scale bar $=20 \mu \mathrm{m}$. 44. Another primary papillae shape (posterior view). Note the spherical apical piece and the small number of rank of scales on the base. Scale bar $=20$ $\mu \mathrm{m}$. 

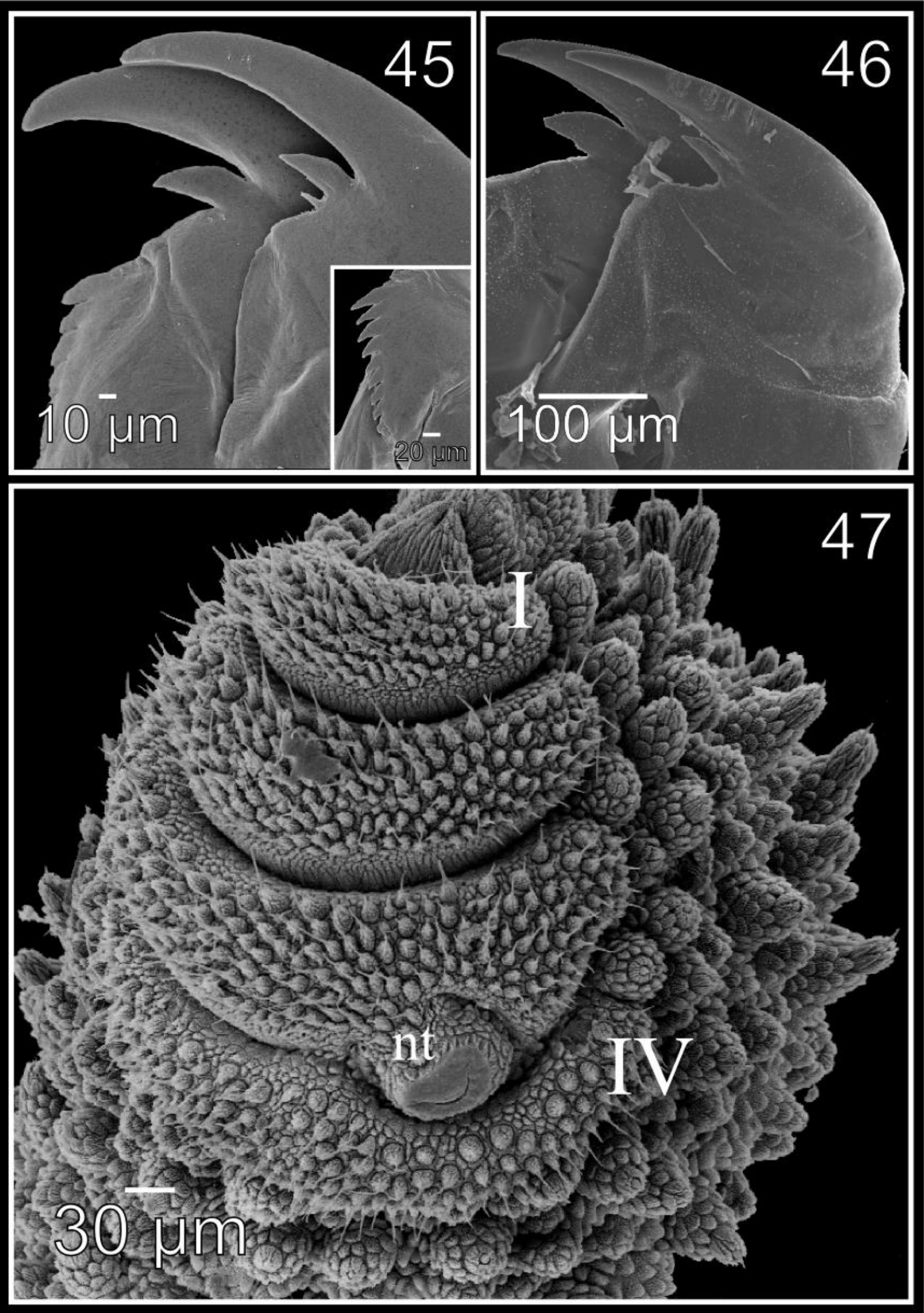
Figures 45 to 47. Epiperipatus machadoi Oliveira and Wieloch; MZUSP 0043; Caratinga. Teeth formula and shape. 45. Left jaw (outer blade in first plan). Note the reduced second accessory tooth. Scale bar $=10 \mu \mathrm{m}$. Detail of the denticles series of the outer blade (see the small box). Scale bar $=$ $20 \mu \mathrm{m}$. 46. Left jaw of another specimen, but without evidence of a second accessory tooth. 47. Spinous pad of the fourth left leg. The roman numerals show the first and last spinous pads. Note the connexion between the fourth spinous pad and the nephridial tubercle. Scale bar $=30 \mu \mathrm{m}$. Lengend: $\mathrm{nt}=$ nephridial tubercle. 


\title{
16) Epiperipatus cratensis Brito, Pereira, Ferreira, Vasconscellos \& Almeida, 2010
}

\author{
(Figures 48 to 56)
}

Epiperipatus cratensis Brito et al., 2010: 49; Oliveira et al. 2012: 9

Epiperipatus brasiliensis: Sampaio-Costa et al. 2009: 556 (misidentification)

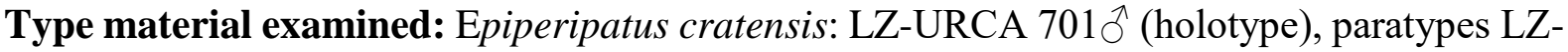
URCA 591, , 702 $\hat{\jmath}, 703 \hat{\jmath}$ (paratypes); BRAZIL, Municipality of Crato, State of Ceará, northeastern Brazil; lost, not examined.

Examined material. MZUSP 0083; 1§ึ; BRAZIL, Ceará, Crato, APA da Chapada do Araripe; 20-30.i.2014; Sampaio, C. S., DaSilva, M. B. e Saraiva, N. E. V. leg. MZUSP 0084; 2 , 1 $\oint^{\Uparrow}$; BRAZIL, Ceará, Crato, FLONA de Araripe-Apodi; 20-30.i.2014; Sampaio, C. S., DaSilva, M. B. e Saraiva, N. E. V. leg. MNRJ 0022; unsexed; BRAZIL, Ceará, Crato; no date data; Rolim Alencar leg.

Diagnosis: The measurements vary from 27 to $34 \mathrm{~mm}$ long, 4.7 to $5.2 \mathrm{~mm}$ wide and $2.7 \mathrm{~mm}$ tall. Dorsal body background is Moderate Brown and has no evidence of dorsal patterns. Twelve complete plicae per segment and no evidence of incomplete plicae. Dorsal papillae present roundish insertion dome, and the primary papillae show asymmetrical and spherical apical piece, which is well-developed. The number of legs varies with from thirty to thirty-four pairs.

Redescription: Measurements. The measurements vary from 27 to $34 \mathrm{~mm}$ long, 4.7 to $5.2 \mathrm{~mm}$ wide and $2.7 \mathrm{~mm}$ tall. However, there is no details about the holotype. Between the sexes, in males the measurement varies from $27 \mathrm{~mm}$ long and $4.7 \mathrm{~mm}$ wide. In females the measurement varies from $32 \mathrm{~mm}$ long and $5.2 \mathrm{~mm}$ wide. Among the specimens examined here, the measurements vary from 44 to $55.3 \mathrm{~mm}$ long, 2.1 to $4.0 \mathrm{~mm}$ wide and 1.4 to $2.8 \mathrm{~mm}$ tall. Males are 41.6 to $44 \mathrm{~mm}$ long, 2.1 to $4.0 \mathrm{~mm}$ wide and 1.4 to $2.0 \mathrm{~mm}$ tall. Females are 47.4 to $55.3 \mathrm{~mm}$ long, 3.0 to $3.7 \mathrm{~mm}$ wide and 1.4 to $2.8 \mathrm{~mm}$ tall. The neotype is $44 \mathrm{~mm}$ long, $4.0 \mathrm{~mm}$ wide and $2.0 \mathrm{~mm}$ tall. Color (living specimens). Dorsal body background is Moderate Brown (58). The dorsomedian furrow is Grayish Reddish Brown (46), without dorsal patterns, but random big primary papillae that are Light Brown (57) are present on whole dorsal side. The Antenna are Moderate Brown (58) like the body background, but with the head Brownish Orange (54). A slim band of Moderate Brown (58) connects the antennae and dorsomedian furrow on the front of the head. Brownish Pink (33) spreads out on 
the whole ventral body background. Ventral organs Light Grayish Yellowish Brown (79) and spinous pads Dark Grayish Yellow (91).

Body description. The dorsomedian furrow and hyaline organs are clearly evident for the whole length of the axis. There are twelve complete plicae per segment, no evidence of incomplete plicae as in E. brasiliensis. The dorsal plicae have uniform width across the dorsal integument and seven of them cross over to the ventral side. Dorsal papillae distributed on all plicae. Primary papillae are the largest dorsal papillae, all of them presenting a roundish insertion dome and asymmetrical spherical and well-developed apical piece. However, some primary papillae are as small as accessory papilla. The base and the apical piece show similar measurements. These parts present a long range of scale ranks. Five to eight scales ranks for the whole contour of the base. The apical piece shows strong asymmetry of scale ranks between anterior and posterior regions. In the anterior region the range varies from three to six scales ranks, while in the posterior region there are two or three scale ranks. The bristle is moved to the posterior region of the apical piece. The accessory papillae are the smallest and present a roundish insertion as well. In quantity, the accessory papillae are more abundant than the primary papillae on the plicae. Usually the primary papillae are separated (and are rarely close together) from each other by one to five accessory papillae. In arrangements with more than three accessory papillae, they are distributed by the top and the flanks of the plicae. On the top of the body the dorsal papillae are more isolated from each other, but they become close together near to the ventral side. All dorsal papillae occur on the plicae, but only the accessory papillae can occur over the flanks, and rarely.

Head. No evidence of structures or patterns on the head. In the original description it cites a variation of between thirty-one to thirty-six antennal rings. However, forty-one to forty-four antennal rings were counted among the specimens examined. The antennal tip is composed of seven large rings, excluding the disc on the top, and followed by a sequence of slim and large rings until the twenty-fifth ring, at least. Eyes and frontal organs present in the external ventrolateral region of the antennal base. The length of the frontal organs is equivalent to five fused antennal papillae. In the original description only five pairs of mouth lobes were counted, but it seems to be unlikely. The mouth opening shows one small and unique lobe followed by seven lobes in a decreasing sequence from anterior to posterior sides of the mouth. Jaws dental formula: 1/1 and 1/1/9-10.

Legs. Intra-specifically the number of legs varies from thirty-three to thirty-four pairs (see Brito et al. 2010: 51). Reexamining the species these numbers vary within males from thirty to thirty-three and in females from thirty-three to thirty-four. On the fourth and fifth pair of legs there are at least 
four complete spinous pads, without evidence of a fifth spinous pad. The nephridial tubercle occurs on the fourth and the fifth pair of legs, between the third and the fourth spinous pads. This organ is connected by the top with the third spinous pad and free of the fourth spinous pad. There are two prolateral and one retro-lateral foot papillae on the feet of the fourth and fifth legs. Ventral and preventral organs are evident. The gonopore is located close to the penultimate pair of legs in both.

Sexual dimorphism. Two or three pregenital legs present crural papillae and there are one or two crural papilla each. Inconspicuous anal glands represented only by the respective two pores on the anterior board of anal aperture.

Diagnostic molecular characters: Characterized for unambiguous synapomorphies transformations for $12 \mathrm{~S}$ in nine positions, for $16 \mathrm{~S}$ in six positions and for $18 \mathrm{~S}$ in four positions (See Costa et al. in prep.).

Comments: Sampaio-Costa et al. (2009: 556) expanded the E. brasilensis distribution including records from the Crato states. In schedula Mello-Leitão, whom was an important Brazilian arachnologist, identified the Crato's specimen as Epiperipatus brasiliensis xerophilus that was corroborated by Sampaio-Costa et al. (2009). Brito et al. (2010) did not mention this specimen and in consequence Crato became a locality shared by E. brasiliensis and E. cratensis. The type material was deposited at the collection of Universidade Regional do Cariri (URCA) from Crato (Ceará state) with the collection number LZ-URCA 701 (holotype) and LZ-URCA 591, 702 and 703. This institution was visited, but the collection does not exist nowadays. At URCA there are four specimens not identified that were used for the original description of this species. Two of those are accompanied by the labels containing the data (labels data literally copied):

1. Brasil, Ceará, Crato, Nascente do Rio Batateiras, 05.ii.2003, L. A. Souza. col.

2. Brasil, Ceará, Crato, Rio Batateiras, 05.viii.2007, Brito, S.V. col.

In this case, the specimens that were examined seem to belong to E. cratensis. After comparing the specimens, the present study concluded only E. cratensis occurs in Crato. This species shows that the primary papillae with spherical apical piece differs from E. brasiliensis, which presents primary papillae with cylindrical apical piece. Epiperipatus cratensis seems to be an endemic species and restrict to the Chapada do Araripe, on the Caatinga enclaves moist forests areas.

Type locality: Brazil, Ceará, Crato, APA da Chapada do Araripe/FLONA de Araripe-Apodi. 


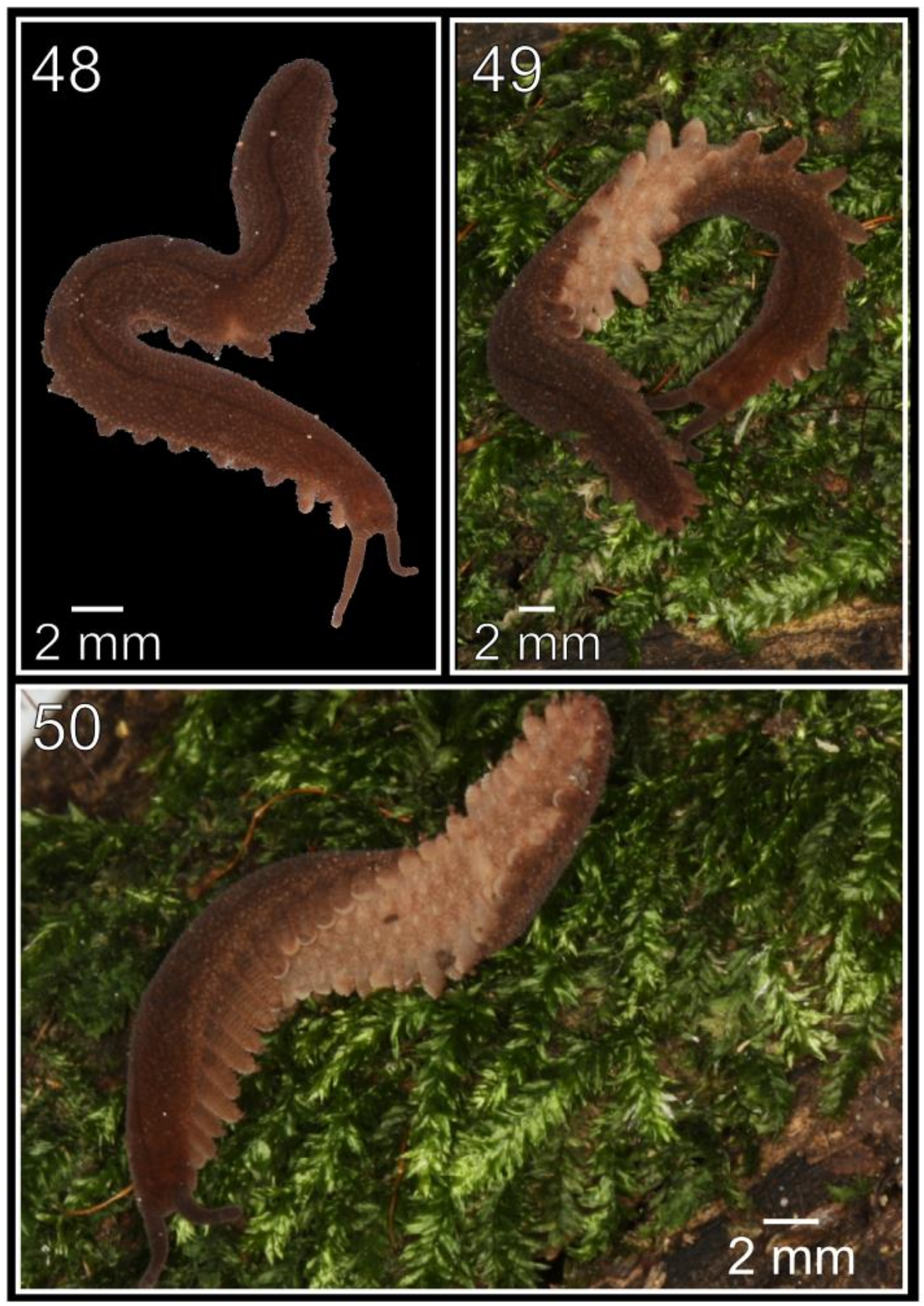


Figures 48 to 50. Epiperipatus cratensis Brito et al.; MZUSP 0084; Crato. 48. Body background of dorsal side. Scale bar $=2 \mathrm{~mm}$. 49 and 50. Body background of the dorsal and ventral side. In the last two images the ventral organs are clearly visible. Scales bar $=2 \mathrm{~mm}$. 


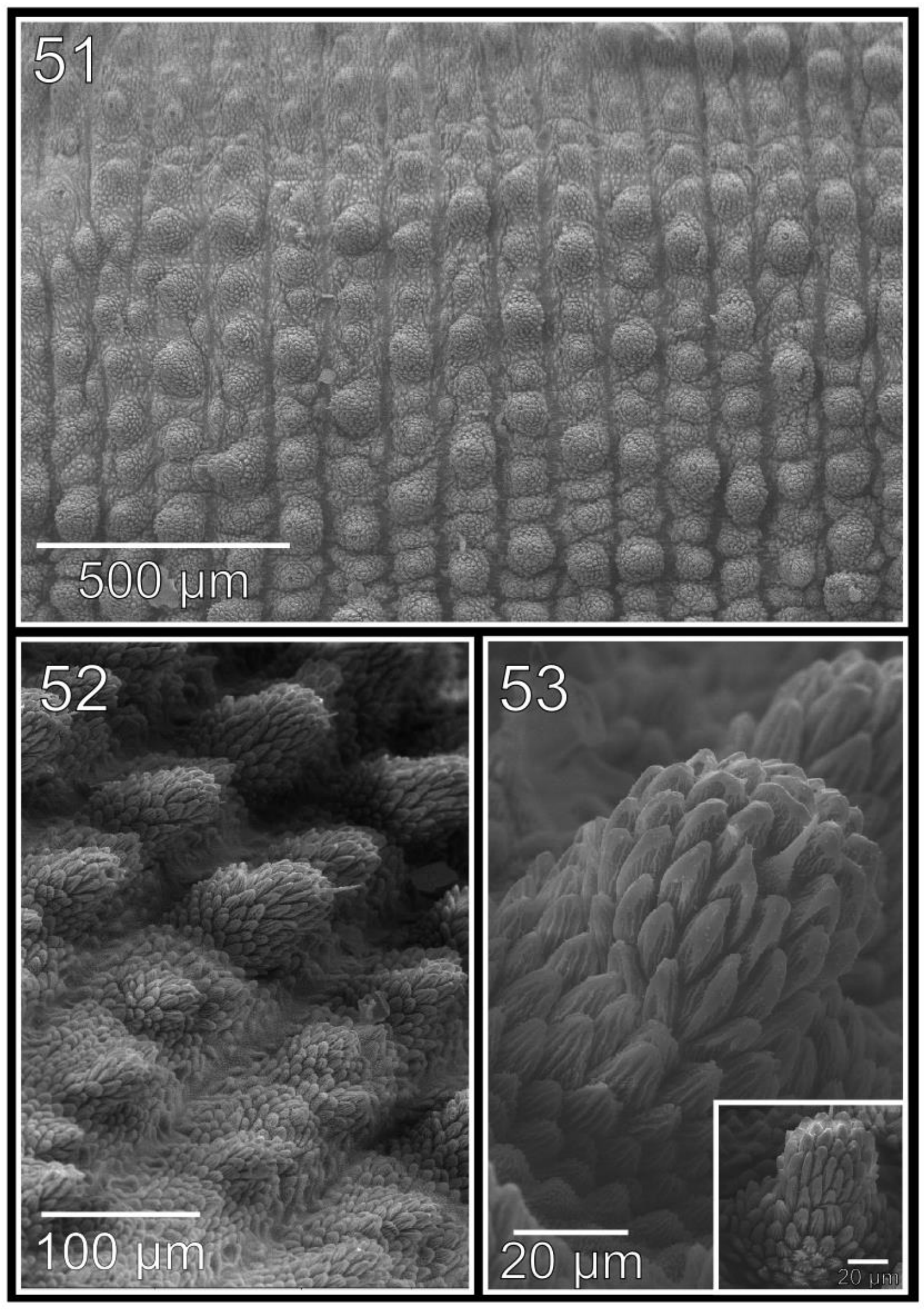


Figures 51 to 53. Epiperipatus cratensis Brito et al.; MZUSP 0084; Crato. 51. Dorsal papillae arrangement around to the dorsomediam furrow (in the top of image). Scale bar $=500 \mu \mathrm{m}$. 52. Dorsal papillae arrangement in lateral view with the bristle moved to the posterior region. Note the different size between the primary and accessory papillae also. Scale bar $=100 \mu \mathrm{m}$. 53. Primary papillae shape in the posterior region. Note the range of three scale ranks on the apical piece. Scale bar $=20 \mu \mathrm{m}$. The anterior region presents a range of four scale ranks as demonstrated in the small box. Scale bar $=20 \mu \mathrm{m}$. 

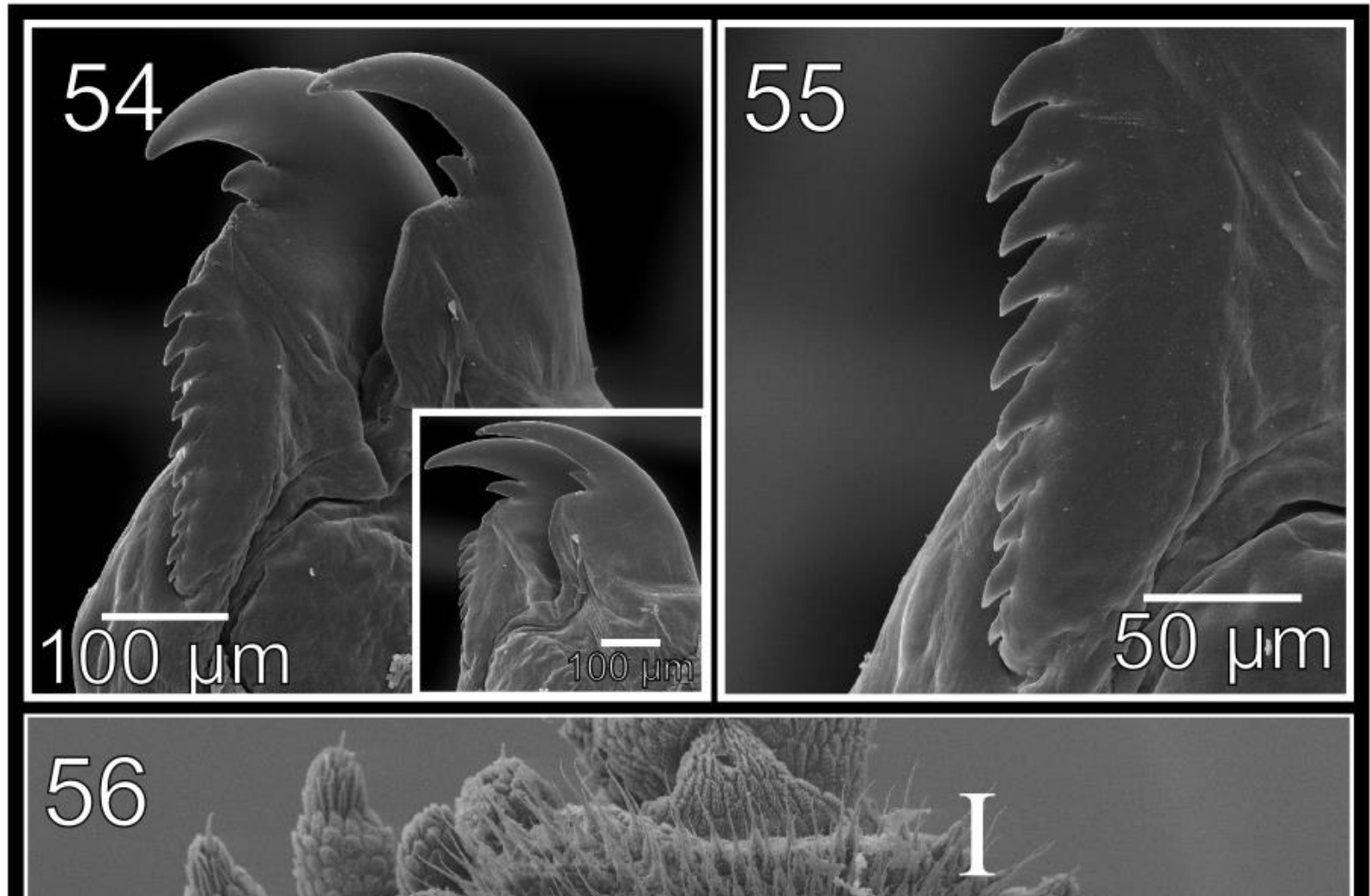

nt

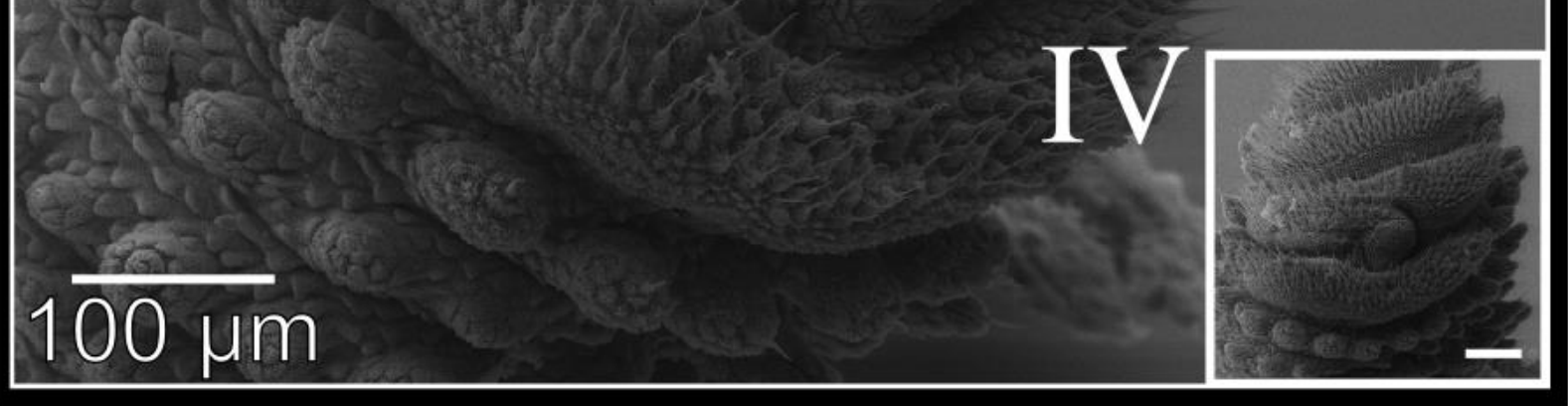


Figures 54 to 56. Epiperipatus cratensis Brito et al.; MZUSP 0084; Crato. Teeth formula and shape. 54. Left jaw (outer blade in first plan). Scale bar $=100 \mu \mathrm{m}$. The principal teeth shape are observed in small box. Scale bar $=100 \mu \mathrm{m}$. 55. Detail of the denticles series of the outer blade, with ten denticles. Scale bar $=50 \mu \mathrm{m}$. 56. Spinous pad of the fourth right leg. The Roman numeral showing the first and last spinous pads. Scale bar $=100 \mu \mathrm{m}$. The spinous pads from the second to the fourth pairs of legs can be observed in the complete ventral region (see the small box). Scale bar $=100 \mu \mathrm{m}$. Legend: $\mathrm{nt}$ $=$ nephridial tubercle. 
Distribution: Brazil, Ceará, around to the APA da Chapada do Araripe/FLONA de AraripeApodi complex.

\section{7) Epiperipatus diadenoproctus Oliveira, Lacorte, Fonseca, Wieloch \& Mayer, 2011}

Epiperipatus diadenoproctus Oliveira et al., 2011: 4; Oliveira et al. 2012a: 10

Type material examined: (Paratypes) UFMG 0110, 0113, 0141, 0155; 4우 BRAZIL, Minas Gerais, Simonésia, Reserva Particular do Patrimônio Natural Mata do Sossego; 15-19.vii.2008; Oliveira, I. de S., Queirós, F.N.S. leg.

Examined material. MNRJ 0012; 1 ; ; BRAZIL, Minas Gerais, Simonésia, Reserva Particular do Patrimônio Natural Mata do Sossego; 07-19.iii.1999; Caramaschi, U., Feio, R.N., Niemeyer, H. de \& Napoli, M.F., leg.; MZUSP 0038, 0039; 1 ㅇ and 10ึ; idem; 25-31.v.2012; Costa, C. S., Guil, A. L. F., Silva, M. P. leg.

Diagnosis: This species combines morphology and molecular data in the original diagnosis. However E. diadenoproctus presents a body background of Reddish Brown, and anal glands have two well-developed pores (like light spots) on the anterior board of anal aperture (male feature). The number of legs varies from twenty-six to thirty pairs of legs: twenty-six to twenty-eight in males, and twenty-nine to thirty in females.

Redescription: Measurements. The measurements vary from 10 to $68 \mathrm{~mm}$ long, 2.0 to $5.0 \mathrm{~mm}$ wide and 1.0 to $3.0 \mathrm{~mm}$ tall. In the specimens examined here the measurements are included in the range described of the original description. Between the sexes, the unique male examined is $30 \mathrm{~mm}$ long, $3.0 \mathrm{~mm}$ wide and $1.7 \mathrm{~mm}$ tall. Among the females examined, the measurements vary from 32 to $68 \mathrm{~mm}$ long, 2.4 to $4.2 \mathrm{~mm}$ and 1.5 to $4.0 \mathrm{~mm}$ tall. Color (living specimens). The dorsal and ventral colors patterns are the same observed for E. adenocryptus (see detail describe in E. adenocryptys description here and in Oliveira et al. 2011:2).

Body description. The dorsomedian furrow and hyaline organs are clearly evident for the whole length of the axis. Hyaline organs are sometimes are hard to observe. The dorsal plicae as width uniform as described of the previously described species. There are twelve complete plicae per segment, two of them are incomplete and seven cross over to the ventral side. Primary papillae are the largest dorsal papillae, all of them presenting a roundish insertion dome and asymmetrical 
spherical apical piece. The basal piece is bigger than the apical piece and showing a range of five to eight scale ranks, while in the posterior region. The apical piece range varies from two or three scale ranks in the anterior region. The bristle is moved to the posterior region of the apical piece. The accessory papillae are the smallest, but some of those as big as the basal piece of a primary papilla. The accessory papillae present a roundish insertion as well. In quantity, the accessory papillae are more abundant than the primary papillae on the plicae. Primary papillae are separated from each other (rarely close together) with one to three accessory papilla. However, on the incomplete plica there are sequences of six accessory papillae after a primary papilla. All dorsal papillae are on the plicae and never occur over the flanks.

Head. No evident structures or patterns on the head. The antennae are composed of thirty-four to forty-two rings in both sexes. The antennal tip is composed of seven large rings, excluding the disc on the top, and followed by a sequence of slim and large rings until around, at least, the twentieth antennal ring. Eyes and frontal organs present in the external ventrolateral region of the antennal base. The length of the frontal organs is equivalent to four fused antennal papillae. The mouth opening is surrounded by one small and unique lobe followed by seven lobes in a decreasing sequence from anterior to posterior sides of the mouth. In the original description the jaws dental formula is: 1/1-2 and $1 / 2 / 10$. However, among the specimens examined the inner blade dental formula was 1/1-2/810.

Legs. Intra-specifically the number of legs varies from twenty-six to thirty pairs of legs. These numbers vary within males from twenty-six to twenty-eight and in females from twenty-nine to thirty. On the fourth and fifth pair of legs there are at least four complete spinous pads and rarely a vestigial fifth spinous pad. The nephridial tubercle occurs on the fourth and the fifth pair of legs, between the third and the fourth spinous pads. This organ is connected at the top with the third spinous pad and free of the fourth spinous pad. There are two prolateral and one retrolateral foot papillae on the feet of the fourth and fifth legs. Ventral and preventral organs are evident. The gonopore is located close to the penultimate pair of legs in both sexes.

Sexual dimorphism. In males there are two pregenital legs present crural papillae and have one crural papilla each. However, a male with double crural papillae in one pregenital leg was reported in the original description. In the male examined three pregenital pair of legs presented crural papillae with the same number of crural papillae per legs. Conspicuous anal glands represented by welldeveloped two pores on the anterior board of anal aperture. 
Comments: E. adenocryptus, E. paurognostus and E. diadenoproctus share a lot of characteristics, but the well-developed anal glands distinguish E. diadenoproctus from the first two species. However, recent phylogenetic studies contrast to the original description. Costa et al. (in prep.) did not recovered the monophyly of Epiperipatus diadenoproctus, E. adenocriptus and E. parougnostus. However, these authors believe that technical artifact could provoke this result. Therefore, prudently this species is kept valid, but it needs revision.

Type locality: Brazil, Minas Gerais, Simonésia, RPPN Mata do Sossego.

Distribution: Brazil, Minas Gerais, Simonésia.

18) Epiperipatus adenocryptus Oliveira, Lacorte, Fonseca, Wieloch \& Mayer, 2011 Epiperipatus adenocryptus Oliveira et al., 2011: 6; Oliveira et al. 2012a: 7

Epiperipatus analogos (invalid name): Lacorte et al. 2010: 342

Examined material: UFMG 0072, 0083, 0089, MNRJ 0084; 4ㅇ; BRAZIL, Minas Gerais, Santa Bárbara do Leste, Córrego dos Ferreiras; 17.vi.2008; Oliveira, I. de S., Genelhú, S. leg.; MZUSP 0030-0032; 3̧ึ; 25-31.v.2012; Costa, C. S., Guil, A. L. F., Silva, M. P. leg. Type material not examined.

Diagnosis: This species combined morphology and molecular data in the original diagnosis. However, with the morphology, the species is able to be recognized due to a poorly developed anal gland papillae, which was bean-shaped, hardly visible, and similar in color to surrounding body. There are twenty-six to thirty pairs of legs, in males this number varies from twenty-six to twentyseven and in females twenty-eight to thirty, without overlap between sexes.

Redescription: Measurements. As the original description the measurements vary from 12.3 to $43.0 \mathrm{~mm}$ long, 1.7 to $4.4 \mathrm{~mm}$ wide and 1.1 to $3.6 \mathrm{~mm}$ tall. In the specimens examined here the measurements are included in the range described in the original description. The males are smaller than the females, as observed for another Peripatidae species. In the examined specimens, among males the measurements vary from 25 to $33 \mathrm{~mm}$ long, 2.0 to $3.0 \mathrm{~mm}$ wide and 1.0 to $2.0 \mathrm{~mm}$ tall. In females, measurements varies from 35 to $43 \mathrm{~mm}$ long, 2.7 to $4.0 \mathrm{~mm}$ and 2.1 to $2.3 \mathrm{~mm}$ tall. Color (living specimens). Dorsal body background Grayish Reddish Brown (46). The narrow dorsomedian furrow is Grayish Red (19) overlapped by unclear diamonds of Strong Yellowish Pink (26). Big 
primary papillae Pale Orange Yellow (73) random distributed over the dorsal side. The antenna and the head are Light Reddish Brown (42). The Grayish Yellowish Pink (32) spreads out, on the whole, ventral body background. Ventral organs, randomly distributed ventral papillae and spinous pads are Light Yellowish Pink (28).

Body description. The dorsomedian furrow and hyaline organs are evident for the whole length axis, but the hyaline organs sometimes can be hard to observe in some specimens. There are twelve plicae per segment, two of them are incomplete and seven cross over to the ventral side. Oliveira et al. 2011 does not described the incomplete plicae and the opposite four dorsal plicae are in anastomosis. Here it was recognized the anastomosis among four plicae, but two of them are the smallest and recognized as incomplete plicae. This trend will be considered for E. diadenoproctus and E. paurognostus. The dorsal plicae has a uniform width as described in previously described species. Dorsal papillae distributed on all plicae. Primary papillae are the largest dorsal papillae, all of them presenting a roundish insertion dome and an asymmetrical spherical apical piece. The basal piece is bigger than the apical piece and showing a range of five to seven scale ranks. In the posterior region of the apical piece, the range varies from two to three (see Oliveira et al. 2011: 2) scale ranks. However, in the specimens examined the apical piece presents only two scales ranks in the posterior region. The bristle is moved to the posterior region of the apical piece. The accessory papillae are the smallest and they present a roundish insertion as well. In quantity, the accessory papillae are more abundant than the primary papillae on the plicae. Primary papillae can be close together or separated by a variable number of accessory papillae. When separated, there are one to six accessory papillae present between two primary papillae. All dorsal papillae are on the plicae, but the accessory papillae, rarely, occur over the flanks.

Head. No evident structures or patterns on the head. The antennae are composed of thirty-six to forty-two rings in both sexes. Different to the original description, here the antennal tip is considered to only be the largest antennal rings until the first narrow ring. So the antennal tip is composed of seven large rings, excluding the disc on the top, and followed by a sequence of slim and large rings until the middle length of the antennae, at least. Eyes and frontal organs present in the external ventrolateral region of the antennal base. The length of the frontal organs is equivalent to four fused antennal papillae. The mouth opening is surrounded by one small and unique lobe followed by six to seven lobes in a decreasing sequence from anterior to posterior sides of the mouth. The jaws dental formula: $1 / 1$ and 1/2/7. On the inner blade, the accessory teeth are not equivalent in size. 
Legs. Intra-specifically the number of pairs of legs varies from twenty-six to thirty. This number varies within males from twenty-six to twenty-seven and in females twenty-eight to thirty. In the specimens examined here the measurements are included in the range described in the original description. The original description has cited, on the fourth and fifth pair of legs that there are at least four complete spinous pads and a fragmented (vestigial) fifth spinous pad. However, the examined specimens do not present vestiges of a fifth spinous pad. The nephridial tubercle occurs on the fourth and the fifth pair of legs, between the third and the fourth spinous pads. This organ is connected at the top with the third spinous pad and free of the fourth spinous pad. There are two prolateral and one retrolateral foot papillae on the feet of the fourth and fifth legs. Ventral and preventral organs are evident. The gonopore is located close to the penultimate pair of legs in both.

Sexual dimorphism. In males there are two pregenital legs present with crural papillae and one crural papilla on each. Inconspicuous anal glands represented only by the respective two pores on the anterior board of anal aperture.

Comments: E. adenocryptus is very similar to E. diadenoproctus and E. paurognostus. Recent phylogenetic study contrasts to the results of the original description (See Costa et al. in prep.). However, prudently this species is kept valid, but it needs revision (See remarks for $E$. diadenoproctus).

Type locality: Brazil, Minas Gerais, Santa Bárbara do Leste, Córrego dos Ferreiras.

Distribution: Brazil, Minas Gerais, Santa Bárbara do Leste.

\section{9) Epiperipatus paurognostus Oliveira, Lacorte, Fonseca, Wieloch \& Mayer, 2011}

Epiperipatus paurognostus Oliveira et al., 2011: 7; Oliveira et al. 2012a: 12

Epiperipatus schedocrypticus (nomen nudum): Lacorte et al. 2010: 342

Type material examined: (Paratypes) UFMG 0060; 1q; BRAZIL, Minas Gerais, Piedade de Caratinga, Mata do Eremitério; 14.vi.2008; Oliveira, I. de S., Genelhú, S. leg.; UFMG 0181; 1 q; idem; 22.vii.2009; Oliveira, I. de S., Lacorte, G.A. leg.; UFMG 0184; 1§; idem; 23.iv.2009; Coelho, H. 
Examined material. MZUSP 0033-0035; 19 and 2§; BRAZIL, Minas Gerais, Piedade de Caratinga, Mata do Eremitério; 25-31.v.2012; Costa, C. S., Guil, A. L. F., Silva, M. P. leg.

Diagnosis: This species combined morphology and molecular data in the original diagnosis. The body background is Reddish Brown, anal glands are poorly developed in two pores on the anterior board of anal aperture (male feature). The number of pairs of legs varied from twenty-six to twenty-nine pairs: twenty-six to twenty-seven in males, and twenty-seven to twenty-nine in females.

Redescription: Measurements. The measurements vary from 10 to $44 \mathrm{~mm}$ long, 1.6 to $5.0 \mathrm{~mm}$ wide and 1.2 to $3.0 \mathrm{~mm}$ tall. Between the sexes, the unique male examined was $29.6 \mathrm{~mm}$ long, 3.0 $\mathrm{mm}$ wide and $1.7 \mathrm{~mm}$ tall. Among the females examined, the measurements varied from 31.8 to 68.4 $\mathrm{mm}$ long, 2.4 to $4.2 \mathrm{~mm}$ and 1.5 to $4.0 \mathrm{~mm}$ tall. Color (living specimens). The dorsal and ventral colors patterns are the same observed for E. adenocryptus (see detail describe E. adenocryptus description here and in Oliveira et al. 2011: 2).

Body description. The dorsomedian furrow and hyaline organs are clearly evident for the whole length axis. Generally the hyaline organs are clearer on the posterior half of the dorsal body. The dorsal plicae have a uniform width as described in the previously described species. There are twelve plicae per segment, two of them are incomplete and other seven cross over to the ventral side. Primary papillae are the largest dorsal papillae, all of them presenting a roundish insertion dome and asymmetrical spherical apical piece. Usually the basal piece is bigger than the apical piece, but sometimes both are equal in size. The basal piece shows a range of five to eight scale ranks, while in the posterior region the apical piece has a range that varies from two to three scale ranks. The bristle is moved to the posterior region of the apical piece. The accessory papillae are the smallest, but some of them are as big as the basal piece of a primary papilla. The accessory papillae present a roundish insertion as well. In quantity, the accessory papillae are more abundant than the primary papillae on the plicae. Primary papillae are never close together with one to five accessory papilla between two primary papillae.

Head. No evident structures or patterns on the head. The antennae are composed of thirty-six to forty-one rings in both sexes. The antennal tip is composed of seven large rings, excluding the disc on the top, and followed by a sequence of slim and large rings until middle of the body antennal, at least. Eyes and frontal organs are present in the external ventrolateral region of the antennal base. The length of the frontal organs is equivalent to five fused antennal papillae. The mouth opening is surrounded by one small and unique lobe followed by seven lobes in a decreasing sequence from 
anterior to posterior sides of the mouth. In the original description the jaws dental formula is: $1 / 1$ and 1/1-2/6-9. However, among the specimens examined the inner blade dental formula is $1 / 1 / 8-10$.

Legs. Intra-specifically the number of legs varies from twenty-six to twenty-nine pairs of legs. These numbers vary within males from twenty-six to twenty-seven and in females twenty-seven to twenty-nine. On the fourth and fifth pair of legs there are at least four complete spinous pads and rarely a vestigial fifth spinous pad. Sometimes the fourth spinous pad is broke in two equivalent fragments. The nephridial tubercle occurs on the fourth and the fifth pair of legs, between the third and the fourth spinous pads. This organ is connected by the top with the third spinous pad and free of the fourth spinous pad. There are two prolateral and one retrolateral foot papillae on the feet of the fourth and fifth legs. Ventral and preventral organs are evident. The gonopore is located close to the penultimate pair of legs in both.

Sexual dimorphism. Two pregenital legs present crural papillae and one crural papilla each. Inconspicuous anal glands represented by poor developed two pores on the anterior board of anal aperture as E. adenocryptus.

Comments: Different to E. diadenoproctus, E. paurognostus is very similar to Epiperipatus adenocryptus. Among the specimens examined it was not possible to find morphological characters exclusive of E. paurognostus. As commented for E. diadenoproctus and E. paurognostus, recent phylogenetic study contrasts to the results of the original description. However, prudently this species is kept valid, but it needs revision (See remarks for E. diadenoproctus).

Type locality: Brazil, Minas Gerais, Piedade de Caratinga, Mata do Eremitério.

Distribution: Brazil, Minas Gerais, Piedade de Caratinga.

\section{0) Epiperipatus simoni (Bouvier, 1899)}

Peripatus simoni Bouvier, 1899b: 271

Peripatus (Epiperipatus) simoni: Clark 1913a: 18

Epiperipatus simoni: Peck 1975: 346; Oliveira et al. 2012a: 12

General comments. The type material was not examined, but the results here concluded that it is not possible for E. simoni to occur in Brazil, as mentioned by Sampaio-Costa et al. (2009: 556), 
due to the large distance between these two localities. It was considered misidentification of E. simoni the specimens from Breves, Ilha do Marajós (Pará state) and from Rio de Janeiro (See Sampaio-Costa et al. 2009). The both records certainly belong to unknown species. E. simoni probably occurs only around Caracas, Venezuela and needs revision.

Type locality: Venezuela, Caracas.

Distribution: Venezuela, Caracas.

\section{1) Epiperipatus barbouri (Brues, 1911)}

Peripatus barbouri Brues, 1911: 305

Peripatus (Epiperipatus) barbouri: Clark 1913a: 18

Epiperipatus barbouri: Peck 1975: 345; Read 1988a: 239; Oliveira et al. 2012a: 8

General comments. It was not examined, but in the original description of E. barbouri there are good generic characteristics which approximate this species to Epiperipatus, because of the roundish dorsal papillae insertion and the nephridial tubercles positioned between the third and fourth spinous pad (Brues 1911: 311). Moreover the range of scale ranks are large on the base (twelve) and small on the apical piece (two) approximate this species to Epiperipatus (Read 1988b: 239).

Type locality: Grenada Island, Grand Etang

Distribution: Grenada Island.

22) Epiperipatus broadwayi (Clark, 1913)

Peripatus (Epiperipatus) trinidadensis var. broadwayi, Clark 1913b: 255

Epiperipatus trinidadensis broadwayi: Peck: 1975: 346

Epiperipatus broadwayi: Read 1988b: 245; Oliveira et al. 2012a: 9

Generic comments. In the original description, Clark (1913b) proposed a variation of $E$. trinidadensis in a weak comparative examination of the color, measurement and number of pairs of 
legs. For Read (1988a), "the differences are considered to be too great to retain sub specific status" and so separated them into two species E. trinidadensis and E. broadwayi. Consequently the former became restrict to Trinidad, while E. broawdayi is endemic of Tobago (See more details about this discussion in Read 1988b).

Type locality: Tobago Island, Scarborough neighbor (See Read 1988b and Oliveira et al. 2012a for details)

Distribution: Tobago.

\section{3) Epiperipatus torrealbai Scorza, 1953}

Epiperipatus torrealbai Scorza, 1953: 785; Oliveira et al. 2012a: 12

Generic comments. The species is only known by the holotype deposited at the Museo de Zoologia de la Universidad Central de Venezuela, and Epiperipatus torrealbai requires revision (See Oliveira et al. 2012a for more details).

Type locality: Venezuela, Caracas, Los Chorros

Distribution: Caracas.

\section{4) Epiperipatus lewisi Arnett, 1961}

Epiperipatus lewisi Arnett, 1961: 218; Peck 1975: 346; Oliveira et al. 2012a: 11

Generic comments. E. lewisi shows primary papillae with a cylindrical apical piece (see figure 5 in Arnett 1961: 217), which is very similar to E. vagans (see previous redescription above) and the nephridial tubercles are positioned between the fourth and fifth spinous pads approximating the species to Epiperipatus. This species requires revision (See Oliveira et al. 2012a for more details).

Type locality: Jamaica, Portland, John Crow Mountains, ca. 16 km (10 miles) southwest of Priestman's river.

Distribution: Extreme east of Jamaica. 


\section{5) Epiperipatus hilkae Morera-Brenes \& Monge-Nájera, 1990}

Epiperipatus hilkae Morera-Brenes \& Monge-Nájera, 1990: 449; Oliveira et al. 2012: 10

Generic comments. Costa Rica is the third most diverse country in number of onychophorans species (nine species) and E. hilkae is one of them. The range of scale ranks on the primary papillae, "apparently two -maximum three- scale ranks in the apical part of the primary papillae; basal diameter about 12 ranks" (Morera-Brenes \& Monge-Nájera 1990: 450) and the position of the nephridial tubercle between the fourth and fifth spinous approximates this species to Epiperipatus. This species requires revision (See Morera-Brenes \& Monge-Nájera 1990 for more details of E. hilkae).

Type locality: Costa Rica, Península de Nicoya, Parque Nacional Barra Honda.

Distribution: Across to Nicoya peninsula.

\section{NOMINA DUBIA}

26) Epiperipatus nicaraguensis (Bouvier, 1900)

Peripatus nicaraguensis Bouvier, 1900a: 395

Peripatus (Epiperipatus) nicaraguensis: Clark: 1913a: 18

Epiperipatus nicaraguensis: Peck: 1975: 346; Oliveira et al.: 2012a: 14

Generic comments. The species was described based on a unique female (with 32 pair of legs) from Matapalga collected by Rothschule, and located at Museum für Naturkunde Berlin (Bouvier 1900). Bouvier also suggested a second record from San Benito, although it seems he did not examine it himself. Oliveira et al. (2012a) considered E. nicaraguensis to be a nomina dubia due to the imprecise type locality (Matagalpa is a huge area in Nicaragua). Therefore, the specimens included in the redescription (Bouvier 1905) brought imprecise data to the identification of the species. $E$. nicaraguenis is closely related to E. edwardsii and E. isthmicola (Bouvier 1905). The relationship to E. nicaraguensis is inferred by the small variation in size among the primary papillae, and to $E$. 
isthimicola by the shape of the fourth spinous pad on the fourth and fifth pair of legs. We do not have access the syntype. Prudently, we prefer to keep the suggestion of Oliveira et al. (2012a) for E. nicaraguensis.

Type locality: Nicaragua, Matapalga.

Distribution: Nicaragua, imprecise data (See Oliveira et al. 2012a).

\section{7) Epiperipatus bouvieri (Fuhrmann, 1913) n. comb.}

(Figures 57 to 63)

Peripatus bouvieri Fuhrmann, 1913: 245; Fuhrmann 1914:186; Peck 1975: 348; Oliveira etal.: 2012a: 24

Examined material: ICN-ONY-13; 19; COLOMBIA, Cundinamarca, Soacha, Vereda San Francisco, Granja Ecológica El Porvenir (2.500 m alt.); 17.viii.2009; Luna, D.. leg. ICN-ONY-27 and 28; 19 and 1ठ; Colombia, Cundinamarca, San Antonio del Tequendama, Reserva Los Tunos; 28.v.2012; Chagas-Junior, A. and Chaparro, E. leg. Type material not examined.

Diagnosis: The measurements varies from: 30 to $56 \mathrm{~mm}$ long, 4.2 to $6.3 \mathrm{~mm}$ wide and 2.5 to $7.0 \mathrm{~mm}$ tall. The primary papillae have a dome base and flat apical piece without clear limit (constriction) between these two parts. The basal piece shows a range around fifteen to eighteen scale ranks, while the apical piece range shows three scale ranks in the anterior and posterior regions. The range of pairs of legs varies from twenty-eight to thirty-three. Males with conspicuous anal glands represented by two light pores on the anterior board of anal aperture.

Redescription: Measurements. The species varies in measurements from: 30 to $56 \mathrm{~mm}$ long, 4.2 to $6.3 \mathrm{~mm}$ wide and 2.5 to $7.0 \mathrm{~mm}$ tall. Color. The examined specimens are discolored and with poorly preserved dorsal diamonds pattern, although a red body background with clear sequences of diamonds were described for the species. Light primary papillae are present, but not so clearly defined.

Body description. Evident dorsomedian furrow and hyaline organs. Twelve plicae per segment with uniform width, with seven crossing over to the ventral side and no evidence of the incomplete plicae. Dorsal papillae with a roundish insertion with a diameter that exceeds the plicae width. Both 
types of dorsal papillae appear to have small size variation, although the accessory papillae on the flanks of the plicae are the smallest dorsal papillae. The primary papillae do not vary in size much among each other and all of them distributed for the whole dorsal plicae. The primary papillae show a dome base and flat apical piece, the limit is not clear between these two parts. The basal piece shows a range around fifteen to eighteen scale ranks, while the apical piece has a range of three scale ranks in the anterior and posterior region. The bristle is asymmetrically accommodated in the posterior region of the apical piece. Only the smallest accessory papillae occur on the flanks of the plicae and rarely on the furrows. The primary papillae can be close together or separate by accessory papillae. The number of the accessory papillae between two primary papillae were pretty hard to determine, but at least from one to three accessory papillae were observed between two primary papillae.

Head. No evidence of patterns on the head. On the antennae there were forty-five to fifty-six antennal rings. The top of the antennae is composed of five large rings followed by the first narrow antennal ring. These rings are followed by a sequence of slim and large rings until around the twentieth ring. Eyes and frontal organs were present in an external ventrolateral region of the antenna insertion. Frontal organs were present, that are in length equivalent to two fused antennal papillae. The mouth opening was surrounded (from anterior to posterior side) by one unpaired small lobe and seven pairs of lobes in a decreasing sequence. Included in the description was data for the jaws dental formula and number of legs; the jaw's formula is $1 / 1-2$ and $1 / 1-2 / 10$, and the range of pairs of legs varies from twenty-eight to thirty-three.

Legs. For each sex the number of pairs of legs were twenty-eight for the unique male examined, and twenty-eight and thirty-three for females. The fourth and the fifth pair of legs show, at least, five complete spinous pads, the last one is the smallest and moved to prolateral position. The nephridial tubercles occur on the fourth and the fifth pair of legs, between the third and the fourth spinous pads, connected only to the third spinous pad. The feet have two prolateral and one retrolateral foot papillae on the feet of the fourth and the fifth pair of legs. Ventral and preventral organs were visible.

Sexual dimorphism. The male showed one pregenital pairs of legs presenting crural papillae and two crural papilla each. Conspicuous anal glands represented by two light pores on the anterior board of anal aperture.

Diagnostic molecular characters: Characterized for unambiguous synapomorphies transformations for COI in thirty-three positions, for $12 \mathrm{~S}$ in twenty-six positions, for $16 \mathrm{~S}$ in thirteen positions and for $18 \mathrm{~S}$ in fifteen positions (See Costa et al. in prep.). 


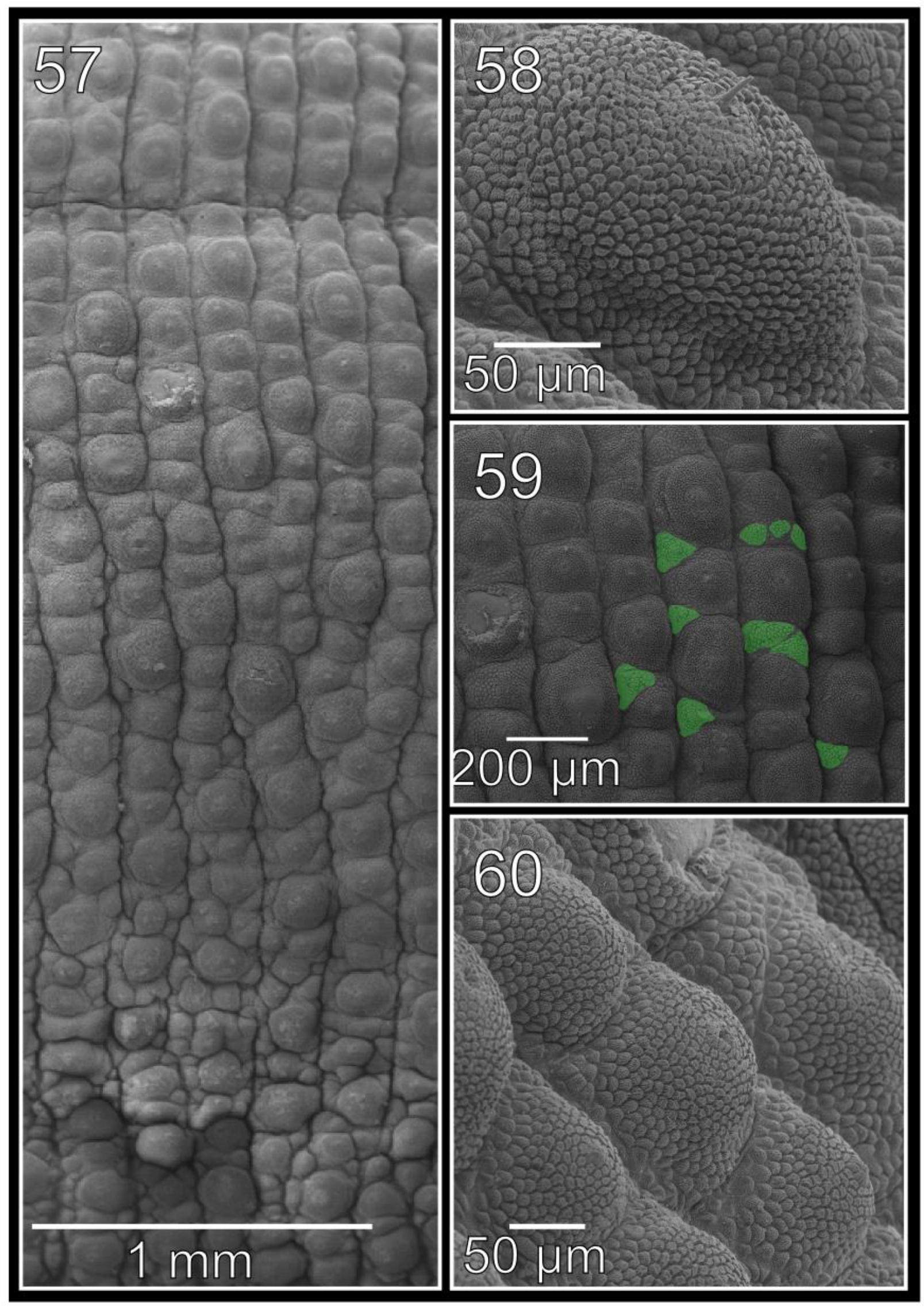


Figures 57 to 60. Epiperipatus bouvieri Fuhrmann n. comb.; ICN-ONY=28; Cundinamarca. 57. Dorsal papillae arrangement around to the dorsomediam furrow (in the top of image). Scale bar $=1$ $\mathrm{mm}$. 58. Primary papillae in anterior view. Note the large range of scale ranks on the base and the flat apical piece. Scale bar $=50 \mu \mathrm{m}$. 59. Dorsal papillae arrangement in dorsal view. Note the small accessory papillae (highlighted in green) present on the flanks of the plicae. Scale bar $=200 \mu \mathrm{m} .60$. Dorsal papillae arrangement. Note the small difference in size of the primary and accessory papillae. Scale bar $=50 \mu \mathrm{m}$. 

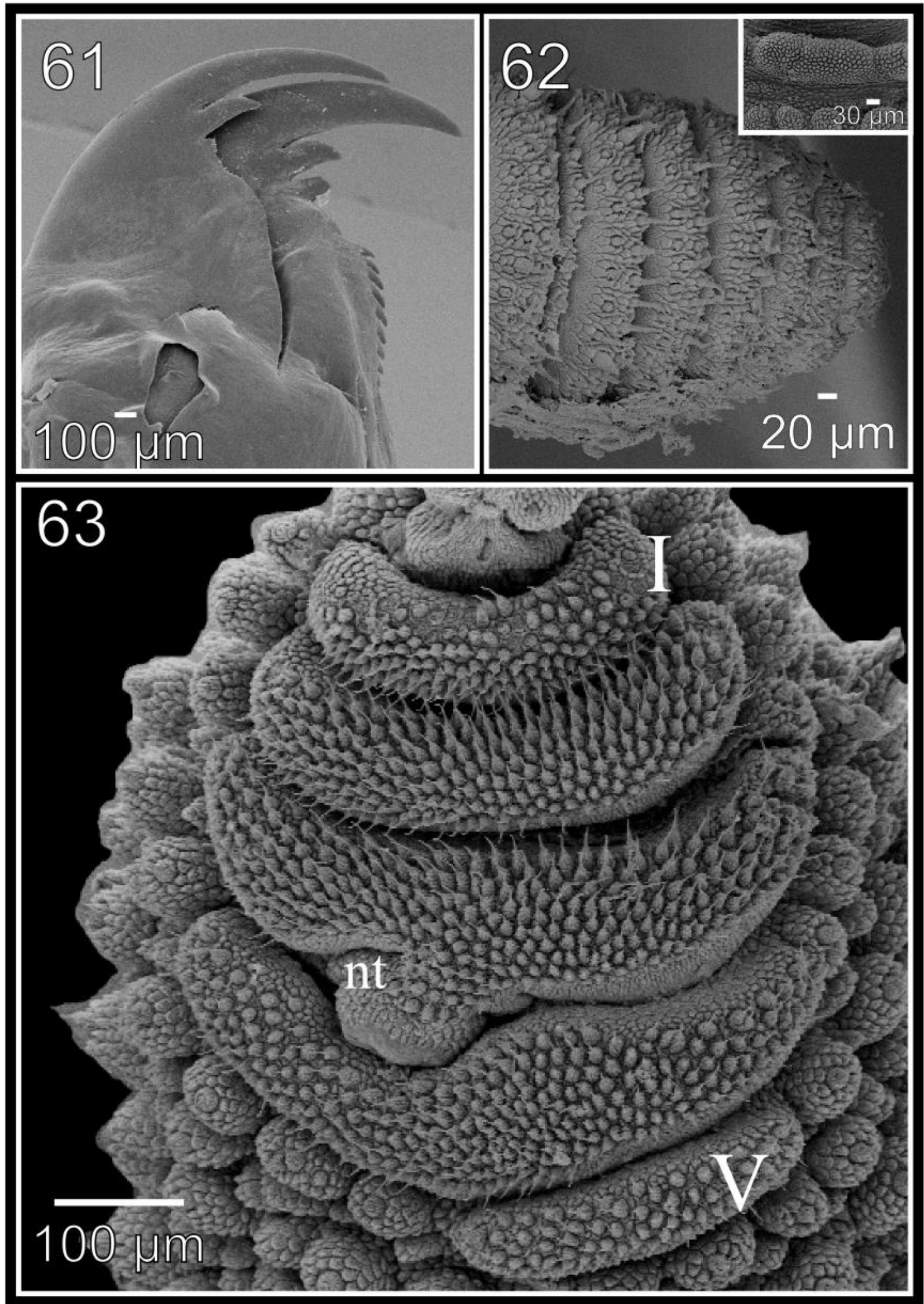
Figures 61 to 63. Epiperipatus bouvieri Fuhrmann n. comb.; ICN-ONY=28; Cundinamarca. 61. Teeth formula and shape of the right jaw (outer blade in first plane). Scale bar $=100 \mu \mathrm{m}$. Note the reduced second accessory tooth, close to the first one, on the outer blade. Scale bar $=100 \mu \mathrm{m}$. 62 . Detail of the top of the right antenna showing five large rings follow by the first slim ring. Scale bar $=20 \mu \mathrm{m}$. 63. Spinous pad of the fourth right leg. The roman numerals show the first and last spinous pads. Scale bar $=100 \mu \mathrm{m}$. Note the fifth spinous shape and length compared with the others three spinous pads. Scale bar $=100 \mu \mathrm{m}$. Legend: $\mathrm{nt}=$ nephridial tubercle. 
Comments: E. bouvieri is one of the largest species of Peripatidae, here the specimens studied were $56 \mathrm{~mm}$ long. The morphology of the primary papillae with a big base and flat apical piece was the most evident characteristic to be able to recognize the species. Moreover, here was the first time a male of E. bouvieri was known and is clearly recognized through the highly evident anal glands. Oliveira et al. 2012a highlighted the nomenclature inconsistency in one Plicatoperipatus mutation, called Peripatus jamaicensis mut. bouvieri (see Cockerell 1901: 326). Here we regard the name bouvieri for the species from Colombia, Boca del Monte described by Fuhrmann (1913).

Type locality: Colombia, Boca del Monte.

Distribution: Colombia, Aruaca, Casanare (See Oliveira et al. 2012a: 24) and Cundinamarca (new record).

\section{8) Epiperipatus solorzanoi (Morera-Brenes \& Monge-Nájera, 2010) n. comb.}

Peripatus solorzanoi Morera-Brenes \& Monge-Nájera, 2010: 979; Oliveira et al.: 2012a: 27.

Examined material: MZUSP 0013; 2ᄋ, 10; COSTA RICA, Limón Province, Guayacán de Siquirres; 01-14.ix.2012; Miguel leg. Type material not examined.

Generic comments. Complementary to the original description, here is described the living specimens color and male features in more detail. The living color is based on the same specimens used by Concha et al. (2015), the body background is Grayish Reddish Orange (39), with random primary papillae of Strong Reddish Brown (40), and any trace of diamond or dorsal patterns and legs were Yellowish White (92). On the ventral side the color was predominantly Light Reddish Brown (44), ventral organs were Light Yellowish Pink (28) and the legs were Pale Yellowish Pink (31). The unique male examined was a juvenile and it showed three pregenital pairs of legs presenting crural papillae and one or two crural papillae on each. The anal glands seem delimited. In spite of being originally described as Peripatus, our work's hypothesis showed P. solorozanoi being closely related to E. biolleyi and E. isthmicola and prudently the combination Epiperipatus solorzanoi was suggested by Costa et al. (in prep). Two dorsal color patterns were recognized in the species. It could mean the existence of a complex species (Morera-Brenes in personal communication), but here it was not tested.

Type locality: Costa Rica, Limón Province, Guayacán de Siquirres. 
Distribution: Costa Rica, Limón Province, Guayacán and Liverpool de Siquirres and Barbilla National Park.

29) Epiperipatus hitoyensis (Oliveira et al., 2012) n. comb.

Principapillatus hitoyensis Oliveira et al.: 2012b: 11

Examined material: IZ 131339; unsexed 2 body segments; CosTA RICA, neat Limón, Reserva Biologica Hitoy-Cerere; xi.2005; Mayer, G. leg; DNA Reference Code: DNA103564. Type material not examined.

Generic comments. The species has the molecular and morphological data support provided by 1000 specimens obtained from cultures producing a good morphology documentation (Oliveira $e t$ al. 2012). In spite of originally being described as a new genus, the phylogenetic results (see Costa et al. in prep.) of the species showed it is close related to E. isthimicola, E. biolleyi and E. solorzanoi, and prudently as the latter the combination Epiperipatus hitoyensis was suggested by Costa et al. (in prep.).

Type locality: Costa Rica, Limón Province, Reserva Biologica Hitoy-Cerere.

Distribution: Costa Rica, Limón Province.

30) Epiperipatus sucuriuensis (Oliveira et al. 2015) n. comb.

Cerradopatus sucuriuensis Oliveira et al.: 2015: 216.

Molecular data accessed: ONY-MTS08; BRAZIL, Mato Grosso do Sul, Chapadão do Sul; xi.2005; Mayer, G. leg; GenBank accession number: KM095121 (COI), KM095127 (12S rRNA). Type material not examined.

Generic comments. This species has the molecular and morphological data support provided by 42 specimens, some of those kept in culture $(n=20)$ producing a good morphology documentation (Oliveira et al. 2012). According to the observations by Costa et al. (in prep.), C. sucuriuensis is closely related to E. acacioi and both species are nested in Epiperipatus. To avoid paraphyly of 
Epiperipatus, Cerradopatus was synonymized with Epiperipatus and the combination Epiperipatus sucuriuensis was suggested by Costa et al. (in prep.). The specimens (approximately 40 specimens) of E. sucuriuensis were examined and the original description mentioning legs with two prolateral and another two retrolateral foot papillae and broke fourth spinous pads. In this case these features could be autapomorphies or mutations that occur in this species.

Type locality: Brazil, Mato Grosso do Sul, Chapadão do Sul.

Distribution: Endemic of the municipality of Chapadão do Sul.

\section{1) Epiperipatus [sp 17] n. sp.}

(Figures 64, 66, and 68-74)

Epiperipatus sp. 1: Sampaio-Costa et al.: 2009: 556 and 557.

Type material examined. Holotype ( + , MNRJ 0057); Brazil, Alagoas state, Murici, Estação Ecológica de Murici (Mata da Bananeira area); no data date; Lo-Man-Hung, N.F. leg. Paratype (ô, MNRJ 0035); idem; 11-18.xiii.2009; Costa, C.S., Giupponi, A. and Chagas-Jr leg.

Examined material. DZUFMG-ONY 0008 and 0009; 2 ; Brazil, Alagoas state, Murici, Estação Ecológica de Murici (Mata da Bananeira); 21.vii.1995 by Freitas, L.M. and Natali, M.S. leg.; MNRJ 0053; 9 +. 4 $\lesssim$ and 1 unsexed; idem; 11-18.xii.2009; Costa, C.S., Giupponi, A. and ChagasJr, A, leg. MZUSP 0010; 1q; idem; 26-29.vii.2012; Costa, C.S., Alcântara, D.M.C., Dias, P.S. and Nihei, S.S. leg. MZUSP 0009; 1 ; ; Brazil, Alagoas state, Estação de Floração e Cruzamento da Serra do Ouro, Universidade Federal de Alagoas; 26-29.vii.2012; idem.

Diagnosis. The species has symmetrical, reduced or hidden apical piece. The pale primary papillae are present in alternate folds. Large body dimension with till $76 \mathrm{~mm}$; Number of legs thirtyeight to thirty-nine.

Description. Measurements. Post-fixated the body dimensions in millimeters, length 16 to 76 , width 2.5 to 6.0 and height 1.0 to 3.0. Color. The body background in vivo is Dark Grayish Red (20), with a dorsal wavy band of Light Grayish Red (18) and overlaid by diamond-shape marks, the same color as the body background (Figure 69). Dorsomedian furrow is Very Dark Purplish Red (260) (Figure 69). Anterior portion of head and antennae are dark purple (224). Color of the dorsal portion 
of the legs is the same as predominant dorsal body color. The biggest primary papillae are pale and distinguishable in vivo by the Light Brown (57) color. They are found on alternate plicae and forming longitudinal sequences on the dorsal integument. There is an increment of number of pale primary papillae as near as to the legs. The legs and ventral surface have the same color pale Pink (7) (Figure 70).

Body description. Dorsal papillae are aligned on the top of the folds with two primary papillae separated by one to three accessory papillae and rarely occurring close together. Both dorsal papillae have conical basal pieces, artichoke like, composed of the lanceolate scales which never overlap each other on the base of papillae (Figure 73). The primary papillae are the biggest and on it is base there are eight or ten scale ranks. The apical piece can be reduced and in both cases there is just one scale rank (Figures 73 and 74). This rank can be overlapped by a scale rank of the base papilla and consequently the constriction between the two parts of the primary papillae is hidden (Figures 73 and 74. See also Sampaio-Costa et al. 2009: 557, figures 6 to 8). When the apical piece is evident it is symmetric and conical with narrow and elongated scales (Figure 73). The needle-shaped sensory bristle is curved or straight placed in central point of apical piece. The accessory papillae are similar to the primary papillae in respect of scale shape and base morphology however it does not have an apical piece.

Head. The number of complete antennal tips counted in the holotype and paratype are fortyfour and forty-five respectively with seven of them composing the antennal tips. On the holotype the interchange among narrow and large rings is from the eighth to the twentieth rings. On the paratype this interchange is observed from the eighth to the eighteenth rings. The mouth opening surrounded by one anterior oral lobe (unpaired lip) and seven pairs of oral lips (Figure 64). The jaws have two blades and both are composed of one long curved principal tooth followed by one accessory tooth (Figures 71 and 72). However the inner blade differs to the outer blade by having a series of teeth composed of seven to eleven denticles. The formula of the inner and outer jaw blades can be interpreted as 1/1 and 1/1/7-11 respectively (Figures 71 and 72).

Legs. Number of legs thirty-eight to thirty-nine. The nephridial tubercle occurs on the fourth and the fifth pair of legs, between the third and the fourth spinous pads such as another species of Epiperipatus (Figure 66). On the fourth and the fifth pair of legs, the fifth spinous pad is present and always reduced (Figure 66). 


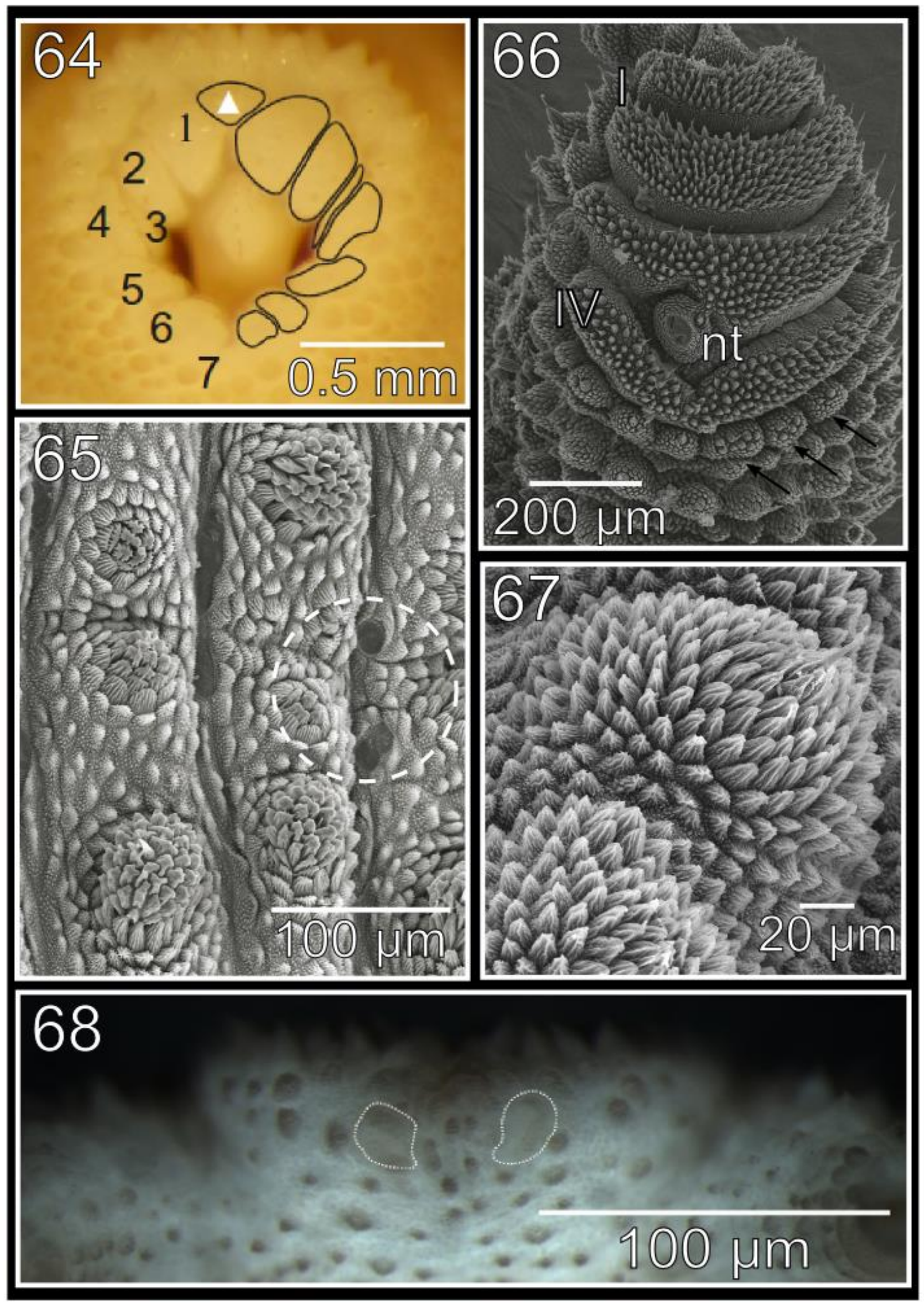


Figure 64. Epiperipatus [sp17] n. sp. holotype mouth opening (lips). The sequence 1 to 7 indicating the pair lips.

Figure 65. Epiperipatus [sp1] n. sp. dorsal papillae. 76, Holotype primary papillae top view following the dorsomedian furrow Note the hyaline organs (highlighted through of the dashed circle) in each side of the dorsomedian furrow.

Figure 66. Epiperipatus [sp17] n. sp. paratype leg on ventral view. Spinous pad and nephridial tubercles. The Roman numbers indicate the first and last spinous pad of the leg. Legend: nt Nephridial tubercles.

Figure 67. Holotype Epiperipatus [sp16] n. sp. primary papilla shape in posterior view. Note the reduced apical piece compare with the basal piece.

Figure 68. Epiperipatus [sp17] n. sp. holotype ventral view with anal opening showed. The dashed draw indicates the anal glands opening. 


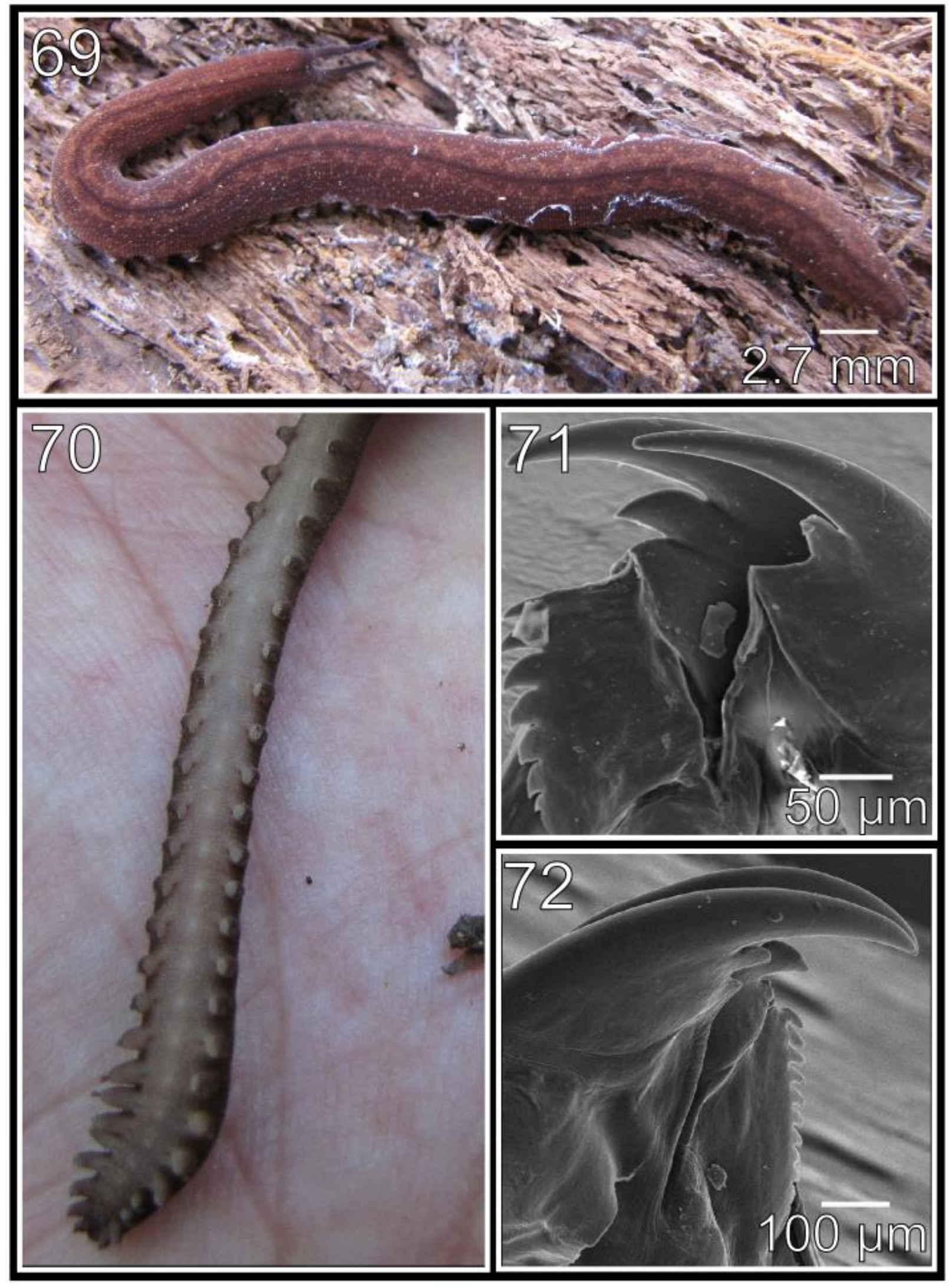


Figures 69 to 72. Epiperipatus [sp17] n. sp. habitus and jaws. 69. Living specimen in dorsal habitus. 70. Living specimen in ventral habitus. 71. Holotype blades. The accessory tooh of outer jaws is broken. 72. Paratype blades. Outer blade in first plane in the both figures, and the white stars indicating a reduced tooth in the inner blade. OJ - outer blade; IJ - inner blade. 
Sexual dimorphism. The males show two or three pregenital legs with one crural papilla each. Inconspicuous anal glands represented only by the respective two pores on the anterior board of anal aperture (Figure 68).

Comments. The males can vary from 29 and $41 \mathrm{~mm}$ long and females from 16 to $76 \mathrm{~mm}$ in length. The antennae have a large number of rings varying from forty to fifty-two rings always with seven of them composing the antennal tips. The interchange among narrow and large rings is observed from the eighth to sometimes the forty-ninth ring.

The number of legs pairs in species varies from thirty-six to thirty-nine. The number overlapping between sexes, thirty-six to thirty-eight in males and thirty-six to thirty-nine in females.

Type locality. Brazil, Alagoas, Murici, Estação Ecológica de Murici.

Distribution. Brazil, Alagoas, Murici.

\section{2) Epiperipatus [sp2] n. sp.}

(Figure 75)

Type material examined. Holotype (ð̂, MNRJ 0101); Brazil, Alagoas state, Murici, Estação Ecológica de Murici (Mata da Bananeira area); 11-18.xii.2009; Costa, C.S., Giupponi, A. and Chagas-Jr leg. Paratype ( $\odot$, MNRJ 0102); idem.

Examined material. MNRJ 0103; $13 q .6 \hat{\sigma}$ and 3 unsexed; razil, Alagoas state, Murici, Estação Ecológica de Murici (Mata da Bananeira area); 11-18.xii.2009; Costa, C.S., Giupponi, A. and Chagas-Jr leg. MZUSP 0011; 1q; idem; 26-29.vii.2012; Costa, C.S., Alcântara, D.M.C., Dias, P.S. and Nihei,S.S. leg.

Diagnosis. Apical piece is cylindrical, asymmetric composed by two scale ranks on back side and three on front side; number of legs twenty-nine to thirty. Description. Measurements. Postfixated the body dimensions in millimeters are, length 13 to $44 \mathrm{~mm}$, width 1.0 to $4.0 \mathrm{~mm}$ and high 1.0 to $3.0 \mathrm{~mm}$. Color. In vivo the body background on dorsal and the disposition of the pale primary papillae, and ventral region are the same as Epiperipatus [sp17] previously described.

Body description. Dorsal papillae are aligned on the top of the folds with two primary papillae occurring close together or separated by one to five accessory papillae. The dorsal papillae have a 
conical basal piece, composed of overlapping lanceolate scales. The primary papillae are of regular size and on their bases there are four to eight of the scale ranks. The apical piece is cylindrical, asymmetrical, composed of two scale ranks on back side and three on front side (Figure 75). This rank is overlapped by a scale ranks of the base papilla and hides the constriction between the two parts of the primary papillae. The needle-shaped sensory bristle is curved or straight and dislocated to back side of the apical piece.

Head. The number of complete antennal rings counted on the holotype were thirty-nine rings with interchanging between narrow and large rings occurring from the eighth to the twentieth rings. Counted on the paratype was forty-six rings and the interchange of the width occurring from the eighth to the eighteenth rings. Antennal tips were composed of seven large rings and a terminal bud. The jaw blades were similar to Epiperipatus [sp17] and the number of denticles on inner blade is eight $(1 / 1 ; 1 / 1 / 8)$.

Legs. Number of leg pairs was twenty-nine to thirty.

Sexual dimorphism. One or two pregenital legs present crural papillae with one crural papilla each, although the structure can be absent on some specimens. Inconspicuous anal glands represented only by the respective two pores on the anterior board of anal aperture.

Diagnostic molecular characters: Characterized for unambiguous synapomorphies transformations for $\mathrm{COI}$ in eleven positions, for $12 \mathrm{~S}$ in four positions and for $16 \mathrm{~S}$ in four positions (See Costa et al. in prep.).

Comments of intra specific variation. Body length of males varied from 13 and $29 \mathrm{~mm}$ and in females from 23 to $44 \mathrm{~mm}$ length. The interchange between narrow and large rings were observed from the eighth to sometimes the twentieth ring. The number of legs pairs varied from twenty-nine to thirty with the number overlapping between the sexes, twenty-eight to twenty-nine in males and twenty-nine to thirty-one in females.

Type locality. Brazil, Alagoas, Murici, Estação Ecológica de Murici.

Distribution. Brazil, Alagoas, Murici. 


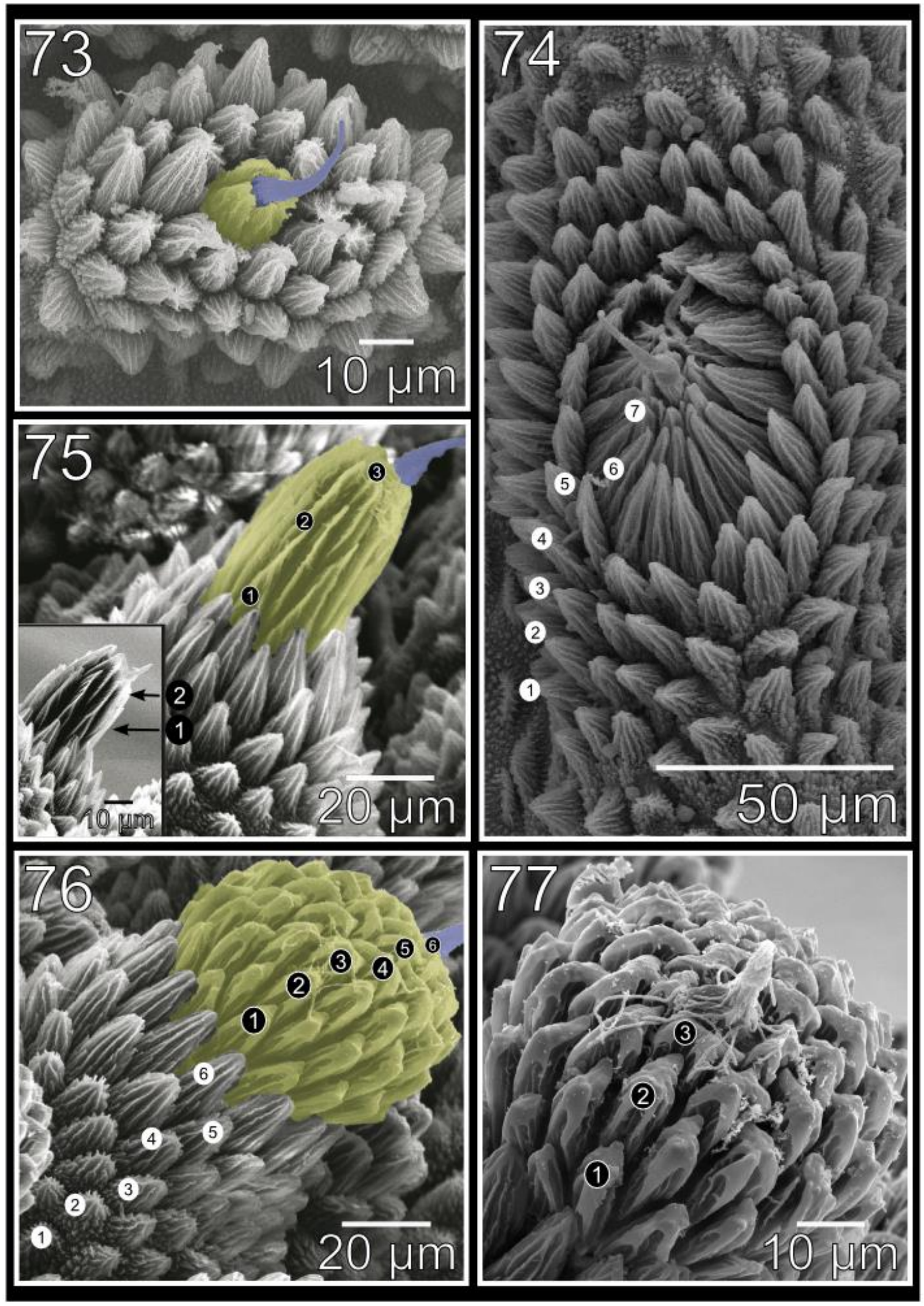


Figures 73 and 74. Epiperipatus [sp17] n. sp. primary papillae. 73. Holotype primary papillae on top view. The apical piece and bristle are highlighted in yellow and purple respectively. 74. Paratype, primary papillae on top view. The white dots indicating the scales on the basal piece, and the small stars indicates the bristle.

Figures 75. Epiperipatus [sp2] n. sp. holotype primary papillae in lateral view. Note the range of three scale ranks in anterior and lateral regions, and two scales ranks in posterior region (see the small square) on the apical piece. The apical piece and bristle are highlighted in yellow and purple respectively such as represented for Epiperipatus [sp17]. Legend: black dots indicating the scales on the apical piece.

Figures 76 and 77. Epiperipatus [sp1] n. sp. primary papillae. 76. Holotype primary papillae anterior view. Note the range of six scale ranks in anterior region. The apical piece and bristle are highlighted in yellow and purple respectively such as represented for Epiperipatus [sp17]. 77. Primary papillae in posterior, showing three scales ranks on the apical piece. Legend: white dots indicating scales from the basal piece, while the black dots indicating the scales from the apical piece. 


\title{
33) Epiperipatus [sp1] n. sp.
}

\author{
(Figures 65, 76 and 77)
}

Type material examined. Holotype ( $\widehat{\jmath}$, MNRJ 0104); Brazil, Alagoas state, Murici, Estação Ecológica de Murici (Mata da Bananeira); 11-18.xii.2009; Costa, C.S., Giupponi, A. and Chagas-Jr leg. Paratype ( 9 , MNRJ 0105); idem.

Examined material. MNRJ 0106; 2 ; Brazil, Alagoas state, Murici, Estação Ecológica de Murici (Mata da Bananeira); 11-18.xii.2009; Costa, C.S., Giupponi, A. and Chagas-Jr leg.

Diagnosis. The species has dorsal papillae with conical basal piece, composed of truncated robust scales and primary papillae are a regular size with six or seven scale ranks on the base and with a robust and asymmetric spherical apical piece; Number of legs twenty-three to twenty-five.

Description. Measurements. Post-fixated the body dimensions in millimeters are length of 26 to $31 \mathrm{~mm}$, width $3.0 \mathrm{~mm}$ and height $3.0 \mathrm{~mm}$. In vivo the body background on dorsal and the disposition of the pale primary papillae, and ventral region is the same as Epiperipatus [sp17].

Body description. Dorsal papillae are aligned on the top of the folds with two primary papillae occurring close together or separated by one to three accessory papillae. The dorsal papillae have a conical basal piece, composed of truncated scales (Figures 65 and 76). The primary papillae have a regular size with six or seven scale ranks on the base and with a robust and asymmetric spherical apical piece (Figures 76 and 77). This one is composed of overlapped scale ranks of six or seven on front side and three on back side (Figure 77). The constriction between the two parts of the primary papillae is hidden (Figures 65, 76 and 77). The needle-shaped sensory bristle is the same as Epiperipatus [sp2].

Head. The number of complete antennal tips counted on the holotype were thirty-seven rings with interchanges between narrow and large rings occurring from the eighth to the fourteenth rings. In the paratype there were thirty-eight rings and the interchange of the widths occurring from the eighth to the sixteenth rings. In both specimens the antennal tips were composed of seven large rings and a terminal bud. The jaws blades are similar to that of Epiperipatus [sp17] and the number of denticles on the inner blade 29like the holotype (dental formula: 1/1/7) and eleven in the paratype (dental formula: 1/1/11).

Legs. Number of leg pairs on the holotype is twenty-three and on the paratype is twenty-five. 
Sexual dimorphism. One or two pregenital legs present with crural papillae and one crural papilla on each. Inconspicuous anal glands represented only by the respective two pores on the anterior board of anal aperture.

Diagnostic molecular characters: Characterized for unambiguous synapomorphies transformations for COI in seventeen positions, for $12 \mathrm{~S}$ in fourteen positions, for $16 \mathrm{~S}$ in twelve positions and for $18 \mathrm{~S}$ in five positions (See Costa et al. in prep.).

Comments of intra specific variation. Male are $26 \mathrm{~mm}$ long, but the females vary from 29 to $31 \mathrm{~mm}$ in length. Moreover, for Epiperipatus [sp1] the number of antennal rings vary from thirty-six to forty-one rings with seven of them composing the antennal tips. The number of legs pairs varies from twenty-three to twenty-five. Females can have twenty-four or twenty-five pair of legs.

Type locality. Brazil, Alagoas, Murici, Estação Ecológica de Murici.

Distribution. Brazil, Alagoas, Murici.

\section{4) Epiperipatus [sp16] n. sp.}

(Figures 67, 78 - 83)

Type material examined. Holotype ( $($, MNRJ 0045) from Reserva Particular do Patrimônio Natural Serra Bonita, Camacan, State of Bahia, collected in 11-15.vi.2009 by Chagas-Jr, A., Dill, V., Giupponi, A., Pedroso, D. \& Kury.

Examined material. ( $1 q$ and 4 juveniles, MZUSP 0017) from Reserva Particular do Patrimônio Natural da Serra Bonita, Camacan, state of Bahia, collected 14.ii to 12.iii.2009 by M. Teixeira Junior

Diagnosis. Apical piece of the primary papillae is symmetrical, reduced, not hidden in the base; the constriction that separates the basal piece and apical piece is not evident; Primary papillae with eight to twelve scale ranks on the base and only one scale rank on the apical piece In vivo the body background is Moderate Yellowish Pink (29) with diamond areas lighter than body background; Light Violet (210) antennae.

Description of holotype. Measurements. Post-fixated the body dimensions in millimeters were a length of 35 to $53 \mathrm{~mm}$, width $2.0 \mathrm{~mm}$ and height $4.0 \mathrm{~mm}$. Color. In vivo the body background on the 
dorsal region and the disposition of the pale primary papillae, and ventral region and is the same as Epiperipatus [sp17]. In vivo the body background of the specimen is Moderate Yellowish Pink (29) with a mid-longitudinal Pale Orange Yellow (73) wavy stripe interrupted by well-defined background color cardioid patches (Figure 78). Dorsomedian furrow thin, Dark Yellowish Pink (30). Anterior portion of head Strong Yellowish Pink (26) gradually turning to Light Violet (210) in the antennae (Figure 78). The body background color of the juvenile is Light Violet (210).

Body description. Dorsal papillae are roundish and close together, rarely varying in the size. The larger pale primary papillae are present, except in juveniles (see comments) and are marked only by the discolored aspect. Dorsal papillae are aligned on the top of the folds and the primary papillae when separated, there are 2 to 4 accessory papillae between them (Figure 79). Base of the primary papillae is conical and the apical piece is symmetrical and reduced, with some exceptions (see comments) (Figures 67 and 80). There are eight to twelve scale ranks on the base and only one scale rank on the apical piece (Figure 80). The bristle on the apical piece is narrow and long, sometimes it seems as long as the apical piece. The accessory papillae are conical, generally with the same size as the primary papillae, but without an apical piece (Figure 81). Plicae are regular and have 12 per segment over the legs, with seven of them crossing to the ventral side and the incomplete plicae can reach half the length of dorsal side (Figure 79).

Head. Number of complete antennal tips counted on the holotype were forty-four rings interchanging between narrow and large rings occurring from the eighth to the fourteenth rings. Among the specimens there were counted forty and forty-two rings and the interchange of the widths occurred from eighth to the sixteenth. The outer blade is composed by one long and curved principal tooth and two accessory teeth (1/2) (Figure 82), while the inner blade has one principal tooth, two accessory teeth and a series composed of twelve denticles (1/2/12) (Figures 82 and 83).

Leg. Number of leg pairs vary from twenty-eight to thirty. On the fourth and fifth pair of legs the nephridial tubercle is observed and it is positioned between the third and fourth spinous pads. It is connected on the top with the third spinous pad by a short isthmus and free from the fourth one, although it is indented in region surrounding the nephridial tubercle. Each foot has three foot papillae, two anterior and one posterior.

Sexual dimorphism. Unknown, only females and juveniles were examined.

Diagnostic molecular characters: Characterized for unambiguous synapomorphies transformations for $12 \mathrm{~S}$ in eight positions and for $16 \mathrm{~S}$ in eight positions (See Costa et al. in prep.). 


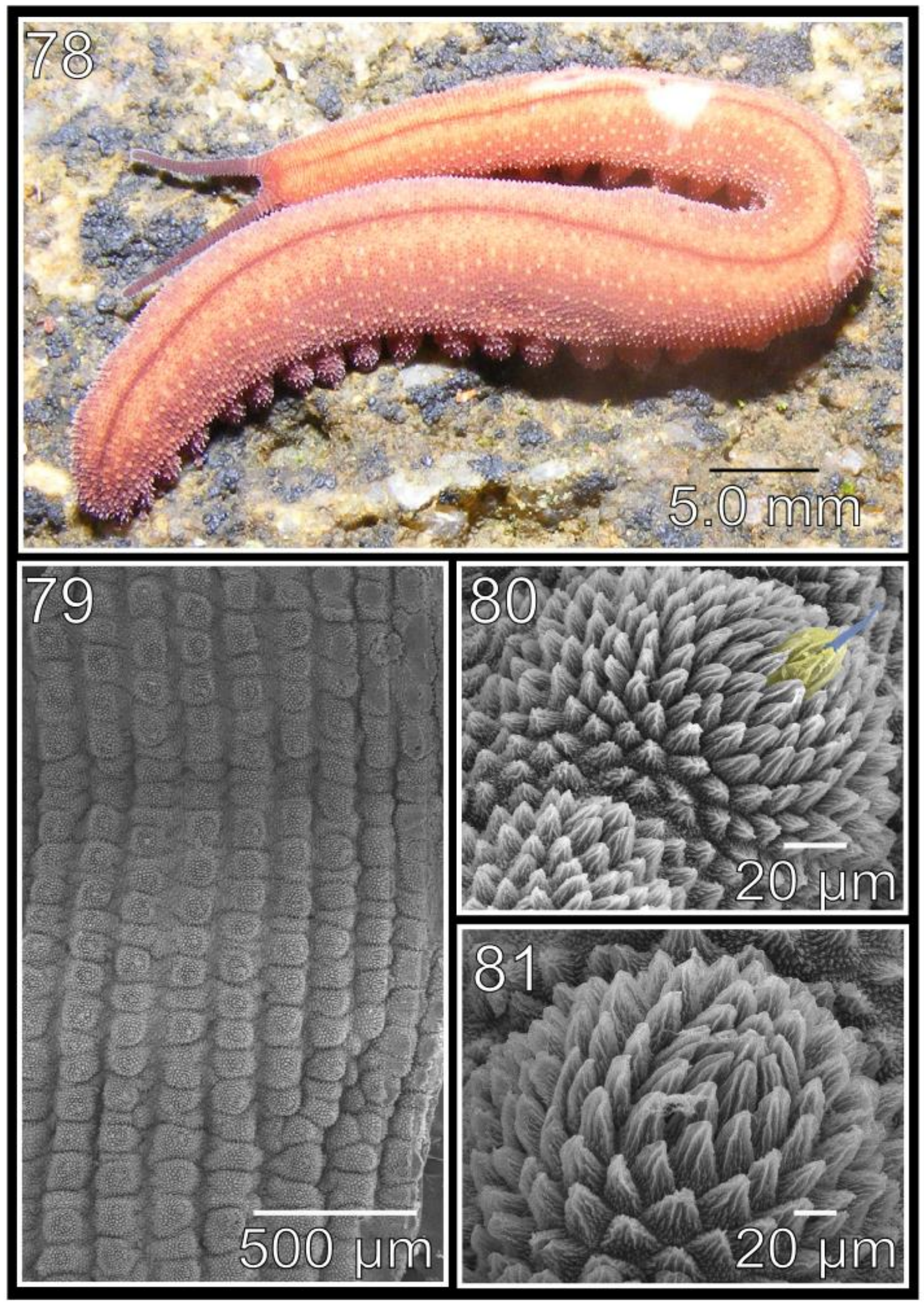


Figures 78 to 81. Holotype. Epiperipatus [sp16] n. sp. dorsal body background and papillae. 78. Body background of dorsal side. 79. Dorsal plicae and papillae arrangement. The dashed rectangle indicates the incomplete plicae. 80. Primary papilla shape in posterior view. Note the range of one scale ranks on the apical piece. The apical piece and bristle are highlighted in yellow and purple respectively such as represented for $E$. [sp17]. 81. Accessory papilla in posterior view. Note slight different shape between the accessory and primary papillae (see the figure 80 ). 

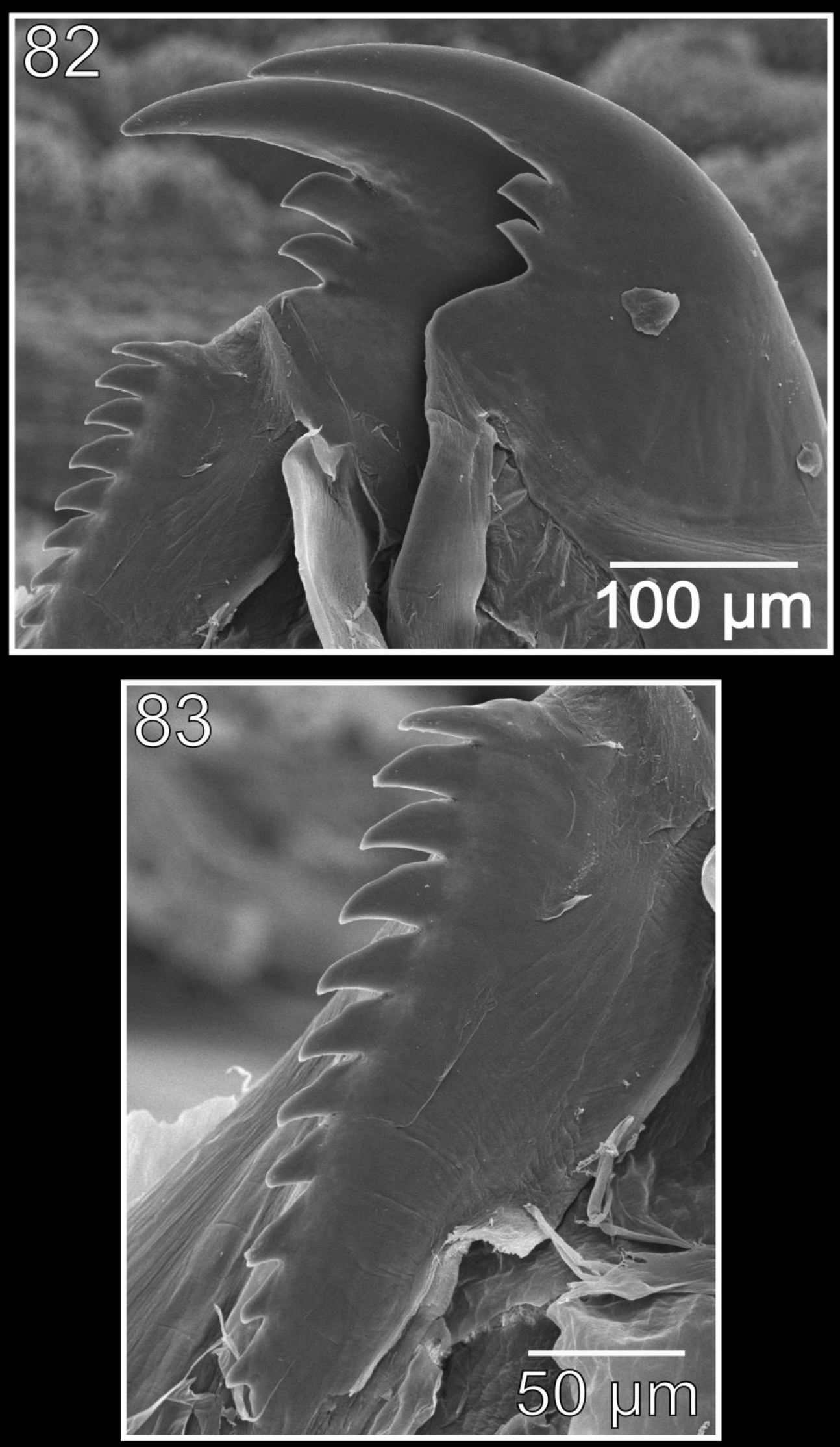
Figures 82 and 83. Holotype. Epiperipatus [sp16] n. sp. teeth formula and shape. 82. Note two accessory teeth for both blades. 83. Detail of the denticles series of the outer blade, with eleven denticles. Legend. OJ - outer blade; IJ - inner blade. 
Comments. A juvenile was photographed in vivo and the body background is Very Dark Purplish Red (260) without diamond areas. The other juvenile post-fixed is darker than the adults, with body background like a Strong Brown (55), diamond areas Brownish Orange (54) and the legs in dorsal region are Pale Yellow (89). Ventrally the body has the same color as the dorsal side of the legs. The juveniles' length varies from 5.0 to $10 \mathrm{~mm}$ long and the width was $10 \mathrm{~mm}$. These measurements were common in all of juveniles. The number of antennal tips counted was 40 plus the terminal button, the frontal organs were present and not distinguished. The dorsomedian furrow, dorsal folds, oral lobes are like in the adults and the hyaline organs seem to be absent. The main difference comparing juveniles and adults is the kind of dorsal papillae. The regular primary papillae and accessory papillae have similar size. In the juveniles, the largest pale primary papillae are more diverse on the dorsal plicae. These primary papillae have a spherical everted and robust apical piece, its arrangement forming longitudinal lines similar to the holotype. The number of pairs of legs counted was twenty-seven to thirty pairs.

Type locality. Brazil, Bahia, Camacan, Reserva Particular do Patrimônio Natural Serra Bonita.

Distribution. Brazil, Bahia, Camacan.

\section{5) Epiperipatus [sp10] n. sp.}

(Figures $84-86$ )

Type material examined. Holotype ( $\curvearrowright$, MZUSP 0022) and paratype ( + , MZUSP 0027); Brazil, Pará state, Marajó island, Breves, Reserva de Extrativista Mapuá, Breves; 4-8.xii.2012; Cristiano Sampaio Costa leg. Syntypes (4 §̋, MZUSP 0023 to 0026), idem.

Diagnosis. Primary papillae are large; base with five or six scale ranks. Apical piece conical and reduced, formed by three scale ranks on the front side and two scale ranks on the back side; primary papillae with small cylindrical apical piece. 


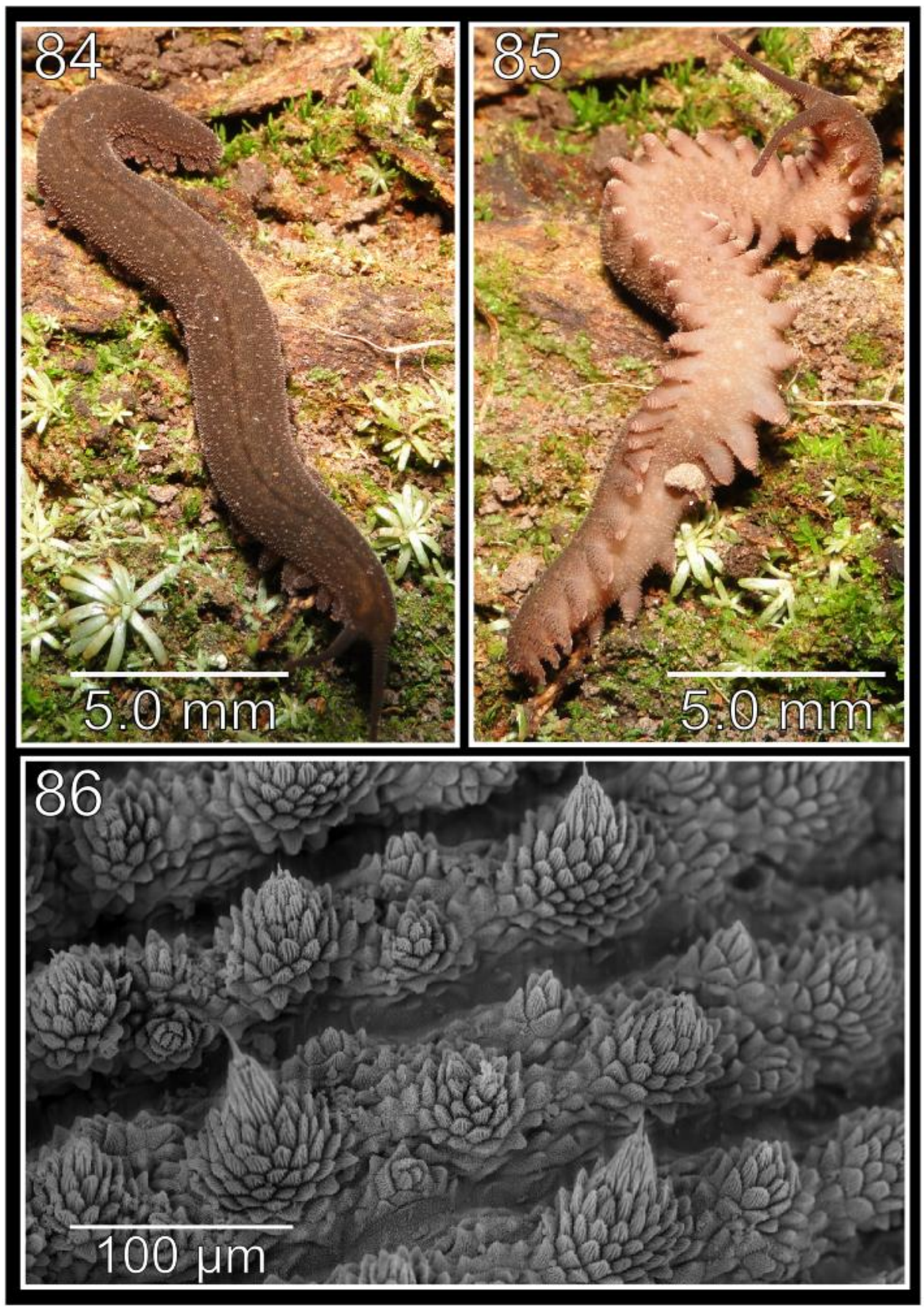


Figures 84 and 85. Epiperipatus [sp10] n. sp. body patterns. 84. Body background of dorsal side. 85. Body background of the dorsal and ventral side. Note the ventral organs clearly visible.

Figure 86. Epiperipatus [sp10] n. sp. holotype. Dorsal papillae arrangement around the dorsomediam furrow in anterior view. Note the elongate apical piece in the primary papillae and the small scale ranks (six) on the basal piece. 
Description of holotype. Measurements. Post-fixated the body dimensions in millimeters were a 27.0 to 34.4 , width 2.0 to 6.0 and height 1.0 to 6.0. Color. The body background is Light Grayish Brown (60) overlaid by Brownish Pink (33) diamond-shaped makers. The Dorsalmedian furrow is Moderate brown (58) and antennae are Grayish Reddish Brown (46) (Figure 84). The biggest primary papillae are pale and distinguishable in vivo by the Light Brown (57) color. They are found on alternate plicae and form longitudinal sequences on the dorsal integument. The dorsal side of legs is the same of color as the dorsal body background. The color is uniform on the ventral surface Grayish Yellowish Pink (32), except by the white spot splashed on the integument (Figure 85). There is an increment of number of pale primary papillae near to the legs.

Body description. Dorsal papillae are aligned on the top of the folds with two primary papillae separated by one to three accessory papillae (Figure 86). Both have conical and artichoke like basal pieces, and they are composed by overlap lanceolate scale ranks. The primary papillae are the largest dorsal papillae and on their bases there are five to six scale ranks. The apical piece is conical and reduced (Figure 86), formed by three scale ranks on front side and two scale ranks on the back side. The constriction between the base and the apical piece is hidden by the scale ranks of the base. The bristle is a little bit moved to the posterior region of the apical piece.

Head. The antennae are composed of forty-three to forty-seven rings. The antennal tip is composed of seven large rings, excluding the disc on the top, and followed by a sequence of slim and large rings until the eighteenth antennal ring, at least. Eyes and frontal organs present in an external ventrolateral region of the antennal base. The length of the frontal organs is equivalent to four fused antennal papillae, although it can be absent also. The jaws have two blades and both are composed by one long curved principal tooth followed by one accessory tooth. The holotype and paratype, on the inner blade, have eight denticles on the tooth series (1/1/8).

Legs. Number of legs in holotype is twenty-seven and paratype is thirty-one.

Sexual dimorphism. One or two pregenital legs present crural papillae with one or two crural papilla on each. Inconspicuous anal glands represented only by the respective two pores on the anterior board of anal aperture.

Diagnostic molecular characters: Epiperipatus [sp10] is characterized for unambiguous synapomorphies transformations only for COI in twenty-one positions (See Costa et al. in prep.).

Comments. Males vary from 27 and $34.4 \mathrm{~mm}$ in length. The antennae have a variation of the number of rings from forty-three to forty-four rings always with seven of them composing the 
antennal tips. The interchange among narrow and large rings is observed from the eighth to sometimes the sixteenth ring. The number of leg pairs varies from twenty-seven to thirty-one and all males examined had twenty-seven pairs of legs and the unique female collected had thirty-one pairs of legs.

Type locality. Brazil, Pará, Breves, Reserva Extrativista Mapuá.

Distribution. Brazil, Pará, Breves.

\section{ACKNOWLEDGEMENTS}

Jerome Murienne, Eduardo Florez, Julián Monge-Nájera and Bernal Morera-Brenes provided specimens to the present study. We also acknowledge partial support funding such as Labex CEBA (ANR-10-LABX-25-01) to collect the Epiperipatus edwardsii specimen. This work was partially supported by FAPESP 2011/20211-0, 2012/02969-6 and 2014/20557-2 to C.S. and R.P.R. authors. Beka Buckman, Brittany Damron and Denis Jacob provided help and comments. We acknowledge the support of the electron microscope laboratory at Bioscience Institute, Bioscience Institute of the Universidade São Paulo, the electron microscope laboratory at Museu de Zoologia da Universidade São Paulo, and the Center for Nanoscale Systems, Harvard University for the SEM images. 


\section{REFERENCES}

Arnett, R. H. 1961. The Onychophora of Jamaica. Entomological News, 72: 213-220.

Blanchard, E. 1847. Recherches sur 1'organisation des Vers. Annales des Sciences Naturelles, [3e Série] 8: 119-149.

Bouvier, E. L. 1899a. Nouvelles observations sur les Péripates américains. Comptes Rendus Hebdomadaires des Seances de l'Academie des Sciences, 129: 1029-1031.

Bouvier, E. L. 1899b. Sur les caractères externes des Péripates. Proceedings of the International Congress of Zoology, 4: 269-271.

Bouvier, E. L. 1900a. Observations nouvelles sur le Peripatus [Onych.]. Bulletin de la Société Entomologique de France [1900]: 394-395.

Bouvier, E. L. 1900b. Nouveau Péripate des environs de Rio-de-Janeiro. Bulletin de la Société Entomologique de France, [1900]: 66-68.

Bouvier, E. L. 1902a. Peripatus biolleyi, Onychophore nouveau de Costa Rica. Bulletin de la Société Entomologique de France, 16: 258-259.

Bouvier, E. L. 1902b. Un Péripate de Costa Rica. Bulletin de la Société Entomologique de France [1902]: 239-240.

Bouvier, E.L. 1904. Sur les Péripates des Guyanes. Bulletin du Museum National d'Historie Naturelle, 10: 52-55.

Bouvier, E. L. 1905. Monographie des Onychophores. Annales des Sciences Naturelles, Zoologie et Biologie Animale, (Série 9) 2: 1-383.

Bouvier E. L. 1907. Monographie des Onychophores. Annales des Sciences Naturelles, Zoologie et Biologie Animale (Série 9) 5: 61-318.

Brito, S. V., Pereira, J. C., Ferreira, F. S., Vasconcellos, A. \& Almeida, W.O. 2010. Epiperipatus cratensis sp. nov. (Onychophora: Peripatidae) from northeastern Brazil. Neotropical Biology and Conservation, 5: 47-52.

Brues, C. T. 1911. A new species of Peripatus from Grenada, with observations on other species of the genus. Bulletin of the Museum of Comparative Zoology, 54: 303-318.

Brues, C. T. 1914. A new Peripatus from Columbia. Bulletin of the Museum of Comparative Zoology, 
58: $375-382$.

Brues, C. T. 1925. Notes on neotropical Onychophora. Psyche, 32: 159-165.

Chagas-Junior, A. \& Costa, C.S. 2014. Macroperipatus ohausi: redescription and taxonomic notes on its status (Onychophora : Peripatidae). Revista de Biología Tropical, 62: 977-985.

Clark, A. H. 1913a. Revision of the American species of Peripatus. Proceedings of the Biological Society Washington, 26: 15-19.

Clark, A. H. 1913b. Piccole note su degli Onychophora. Zoologischer Anzeiger, 42: 253-255.

Clark, A. H. 1915. The present distribution of the Onychophora, a group of terrestrial invertebrates. Smithsonian Miscellaneous Collections, 65: 1-25.

Cockerell, T. D. A. 1901. The Jamaican species of Peripatus. Nature, 63: 325-326.

Cockerell, T. D. A. 1913. A Peripatus from Guatemala. Proceedings of the Biological Society of Washington, 26: 87-88.

Concha, A., Mellado, P., Morera-Brenes, B., Costa, C. S. Mahadevan, L. \& Monge-Nájera, J. 2015. Oscillation of the velvet worm slime jet by passive hydrodynamic instability. Nat. Commun. 6:6292 doi: 10.1038/ncomms7292 (2015).

Costa, C. S., Pinto-da-Rocha, R. \& Giribet, G. Phylogenetic inferences of Epiperipatus Clark 1913 (Onychophora: Peripatidae) based on molecular and morphological data. In preparation.

Ernst, A. 1881. Some remarks on Peripatus edwardsii, Blanch. Nature, 23 (593): 446-448.

Evans, R. 1903. On Peripatus guianensis (sp. nov.). Quarterly Journal of Microscopical Science, 47: $145-160$

Froehlich, C. G. 1962. A Peripatus from Barbados. Boletim da Faculdade de Filosofia Ciências e Letras Universidade de São Paulo, Série Zoologia, 261: 325-334.

Froehlich, C. G. 1968. On some Brazilian onychophores. Beiträge zur Neotropischen Fauna, 5: 160171.

Fuhrmann, O. 1913. Über einige neue neotropische Peripatus-Arten. Zoologischer Anzeiger, 42: 241248.

Fuhrmann, O. 1914. Quelques nouveaux Péripates américaines. In: O. Fuhrman \& E. Mayor (eds). Voyage d'Exploration Scientifique en Colombie. Attinger Frères: Neuchatel, Switzerland. 
Memoires de la Société Neuchateloise de Sciences Naturelles, 5: 176-192.

Gleeson, D. M. 1996. Onychophora of New Zealand; past, present and future. New Zealand Entomologist, 19(1): 51-55.

Graham, L. D., Glattauer V., Li, D., Tyler, M. J. \& Ramshaw, J. A. 2013. The adhesive skin exudate of Notaden bennetti frogs (Anura: Limnodynastidae) has similarities to the prey capture glue of Euperipatoides sp. velvet worms (Onychophora: Peripatopsidae). Comparative Biochemistry and Physiology Part B: Biochemistry and Molecular Biology, 165(4): 250-259. PMID: 23665109; http://dx.doi.org/10.1016/j.cbpb.2013.04.008.

Hertel, W., Wirkner, C. S. \& Pass, G. 2002. Studies on the cardiac physiology of Onychophora and Chilopoda. Comparative Biochemistry and Physiology Part A, 133: 605-609.

Lacorte, G. A., Oliveira, I. S. \& Fonseca, C. G. 2010. Sistemática molecular de onicóforos (Filo: Onychophora) do estado de Minas Gerais. In: $56^{\circ}$ Congresso Brasileiro de Genética. Guarujá, São Paulo, Brazil, 342 pp.

Marcus, E. \& Marcus, E. 1955. A new Peripatus from Minas Gerais, Brazil. Anais da Academia Brasileira de Ciências, 27: 189-193.

Monge-Nájera, J. 1995. Phylogeny, biogeography and reproductive trends in the Onychophora. Zoological Journal of the Linnean Society of London, 114: 21-60.

Morera-Brenes, B. \& León, M.D. 1986. Description of Macroperipatus valerioi n. sp. from Costa Rica, and comments on the genus Macroperipatus (Onychophora: Peripatidae). Revista de Biología Tropical, 34(2): 277-282.

Morera-Brenes, B. \& Monge-Nájera, J. 1990. Epiperipatus hilkae, n. sp. from Costa Rica (Onychophora: Peripatidae). Revista de Biología Tropical, 38: 449-455.

Morera-Brenes B. \& Monge-Nájera J. 2010. A new giant species of placented worm and the mechanism by which onychophorans weave their nets (Onychophora: Peripatidae). Revista de Biología Tropical, 58: 1127-1142.

Moseley, H. N. 1879. Notes on the species of Peripatus, and especially on those of Cayenne and the West Indies. Annals and Magazine of Natural History, [Series 5] 3: 263-267.

Mundie, D. A. 1995. The NBS/ISCC Color System/ David A. Mundie Pittsburgh, PA: Polymath Systems 535.6 dc-20. Retrieved from http://www.anthus.com/ Colors/Cent.html 
Murienne, J., Daniels, S. R., Buckley, T. R., Mayer \& G., Giribet, G. 2014. A living fossil tale of Pangaean biogeography. Proceedings of the Royal Society. B, 281: 20132648. http://dx.doi.org/10.1098/rspb.2013.2648.

Oliveira, I. S. \& Wieloch, A. H. 2005. Macroperipatus machadoi sp. n. (Onychophora: Peripatidae) da floresta atlântica de Minas Gerais, Brasil. Lundiana, 6 (supplement): 61-66.

Oliveira, I. S., Wieloch, A. H. \& Mayer, G. 2010. Revised taxonomy and redescription of two species of the Peripatidae (Onychophora) from Brazil: a step towards consistent terminology of morphological characters. Zootaxa, 2493: 16-34.

Oliveira, I. S., Lacorte, G. A., Fonseca, C. G., Wieloch, A. H. \& Mayer, G. 2011. Cryptic Speciation in Brazilian Epiperipatus (Onychophora: Peripatidae) Reveals an Underestimated Diversity among the Peripatid Velvet Worms. PLoS ONE, 6: 1-13.

Oliveira, I. S.; Read, V. M. St. J., Mayer \& G. 2012a. A world checklist of Onychophora (velvet worms), with notes on nomenclature and status of names. ZooKeys, 211: 1-70.

Oliveira, I. S., Franke, F. A., Hering, L., Schaffer, S. \& Rowell, D. M. 2012b. Unexplored Character Diversity in Onychophora (Velvet Worms): A Comparative Study of Three Peripatid Species. PLoS ONE 7(12): e51220.

Oliveira, I. S, Tait, N. N., Strübing, I. \& Mayer, G. 2013. The role of ventral and preventral organs as attachment sites for segmental limb muscles in Onychophora. Frontiers in Zoology, 2013 $10: 73$.

Oliveira, I. S., Lacorte, G. A., Weck-Heimann, A., Cordeiro, L. M., Wieloch, A. H. \& Mayer, G. 2015. A new and critically endangered species and genus of Onychophora (Peripatidae) from the Brazilian savannah - a vulnerable biodiversity hotspot. Systematics and Biodiversity 13: 211 233.

Peck, S. B. 1975. A review of the New World Onychophora with the description of a new cavernicolous genus and species from Jamaica. Psyche, 82: 341-358.

Read, V. M. S. J. 1988a. The application of scanning electron microscopy to the systematics of the neotropical Peripatidae (Onychophora). Zoological Journal of the Linnean Society, 93: 187223.

Read, V. M. S. J. 1988b. The Onychophora of Trinidad, Tobago and the Lesser Antilles. Zoological Journal of the Linnean Society, 93: 225-257. 
Reid, A. L. 1996. Review of the Peripatopsidae (Onychophora) in Australia, with comments on peripatopsid relationships. Invertebrate Taxonomy, 10: 663-936. doi: 10.1071/IT9960663.

Röhlig, D., Dunlop, J.A., Ruhberg, H. \& Friederichs, A. 2010. An annotated catalogue of the velvet worms (Onychophora) held in the Museum für Naturkunde Berlin. Zoosystematics and Evolution, 86(2): 225-234.

Ruhberg, H. 1985. Die Peripatopsidae (Onychophora). Systematik, Ökologie, Chorologie und phylogenetische Aspekte. In: Schaller F (Ed) Zoologica, Heft 137. E. Schweizerbartïsche Verlagsbuchhandlung, Stuttgart.

Sampaio-Costa, C.; Chagas-Junior, A., Baptista \& R. L. C. 2009. Brazilian species of Onychophora with notes on their taxonomy and distribution. Zoologia, 26(3): 553-561.

Sclater, W. L. 1887. Notes on the Peripatus of Brithish Guiana. Proceedings of the Scientific Meetings of the Zoological Society of London, 9: 130-137.

Sclater, W. L. 1888. On the early stages of the development of South American species of Peripatus. Quarterly Journal of Microscopical Science, 28: 343-363.

Sedgwick, A. 1888. A monograph on the species and distribution of the genus Peripatus (Guilding). Quarterly Journal of Microscopical Science, 28: 431-493.

Scorza, J. V. 1953. Contribución al estudio de los Peripatus Caribes (Epiperipatus) de Venezuela, con adición de una nueva especie. Revista de sanidad y asistencia social, 18: 783-788. 


\section{Capítulo 4. Conclusões}

\section{I - AS ANÁLISES ESCOLHIDAS E SEUS RESULTADOS}

Ainda não há filogenia morfológica proposta para Peripatidae. A maioria dos estudos filogenéticos em Peripatidae que contemplam dados moleculares é baseada em métodos estatísticos como Máxima Verossimilhança e Bayesiana (Daniels \& Ruhberg 2010, Oliveira et al. 2011, Oliveira et al. 2015). Lacorte et al. (2011) e Oliveira et al. (2011) foram os únicos autores a estudarem um gênero de Peripatidae (Epiperipatus), aplicando o método de parcimônia. Esses autores investigaram a diversidade de onicóforos de cinco localidades em Minas Gerais, compreendidas numa área de aproximadamente $100 \mathrm{~km}$ de raio. Para três das cinco localidades, esses autores examinaram em torno de 130 espécimes. Essa investigação culminou na descoberta de E. adenocryptus, E. diadenoproctus e E. paurognostus e na discusão sobre suas relações filogenéticas com E. acacioi e E. machadoi, com base em análises filogenéticas que tiveram E. biolleyi como único grupo-externo. Ambos os autores não explicitaram as estratégias de busca adotadas, o que dificulta a replicação de seus resultados.

O presente estudo contemplou o maior conjunto de dados de Peripatidae, até o momento, analisando conjuntamente dados moleculares e morfológicos, examinados sob os critérios de Máxima Parcimônia (MP) e Máxima Verossimilhança(ML). Métodos de MP e ML apresentam bases teórica e filosófica distintas (conforme apresentado no Capítulo 2), e caracteriza-se um erro comparar resultados de análises cladísticas baseadas em critérios de optimalidade diferentes. As análises em ML foram utilizadas para exame da sensibilidade dos dados sobre diferentes critérios de optimatidade e comparação com resultados do mesmo método presentes na literatura.

Nossos resultados da análise de evidência total contestam o monofiletismo das espécies $E$. adenocryptus, E. diadenoproctus e E. paurognostus apresentados por Oliveira et al. (2011), pois as sequências originais juntamente com as disponíveis no GenBank não resultaram em grupos monofiléticos. Nosso intuito de juntar os dados do GenBank e as sequências originais foi tentar recuperar a topologia apresentada por Oliveira et al. (2011), que, no entanto, não foi recuperada. Entretanto, é possível que esse resultado seja um artefato de técnica, devido à diferença de tamanho (medida em número de pares de base) e quantidade de "missing data" presentes nas sequências originais e do GenBank.

Com relação ao posicionamento de Principapillatus hitoyensis e Cerradopatus sucuruiensis, obtivemos resultados contrários aos resultados que deram origem à proposição desses dois gêneros. 
A topologia apresentada por Oliveira et al. (2012) possui representantes de nove gêneros (quinze espécies), incluindo P. hitoyensis. Essa espécie, junto com Oroperipatus sp., P. solorzanoi e E. biolleyi, formaram um clado que resultou em grupo-irmão das cinco espécies de Epiperipatus abordadas por Oliveira et al. (2011). Na última filogenia de Peripatidae publicada (Oliveira et al. 2015) as espécies neotropicais estavam divididas em dois grandes clados. No primeiro clado, Oroperipatus (do grupo “andicola”) resultou em grupo-irmão do clado formado por E. biolleyi, $P$. solorzanoi e $P$. hitoyensis. No segundo clado, exclusivamente sul-americano, C. sucuriuensis resultou em grupo-irmão de E. machadoi, E. diadenoproctus, E. adenocryptus, E. paurognostus e E. acacioi. Em oposição, os resultados desta tese apontam que o grupo "andícola” é grupo-irmão do grupo “caraíba”, sem exceções, e isso se aproxima dos resultados de Murienne et al. (2014), exceto pelo único Epiperipatus (uma espécie não identificada) inserido no clado de Oroperipatus presente na topologia apresentada por esses autores.

A descrição original de Cerradopatus sucuriuensis Oliveira et al., 2015 é acompanhada de uma análise filogenética que utiliza um número maior de grupos-externos (17 espécies). A topologia mostra um panorama evolutivo aceitável entre as espécies de Peripatidae selecionadas e se aproxima de nossos resultados apresentados no Capítulo 2 (ver Figuras 1 e 2). No entanto, ramos longos evidenciam a presença de clados confiáveis, mas no caso de $C$. sucuriuensis não se justifica a necessidade da criação do gênero. Em nossa interpretação, o resultado de Oliveira et al. (2015) evidencia a existência de dois clados, um da América Central e outro restrito a espécies brasileiras (também mostrado no Capítulo 2), além de existir uma espécie representante de Epiperipatus no cerrado. As características que delimitam esse gênero (estruturas interpedais e deformações do tegumento ventral) são autapomorfias da sua única espécie. A aceitação de Cerradopatus como válido consequentemente resultaria na parafilia de um gênero maior (Epiperipatus) e na criação de gêneros novos para cada clado de espécies monofiléticas encontradas em nossos resultados.

\section{II - CONTRIBUIÇÃO DA MORFOLOGIA E DOS DADOS MOLECULARES PARA OS ESTUDOS FILOGENÉTICOS.}

Bouvier (1905) e Peck (1975) delimitam Epiperipatus a partir das características de distribuição das papilas sobre as dobras dorsais (a distância entre duas papilas adjacentes), e o número de pares de pernas pregenitais que portam papilas crurais (ver Capítulo 2, Lista de Caracteres: caráter 29:1). Read (1988a, 1988b) delimita esse gênero através das fileiras de escamas nas papilas principais (ver Capítulo 2, Lista de Caracteres: caráter 16:1). A distância entre as papilas dorsais aparentemente é um caráter subjetivo e de difícil codificação e, por isso, não foi levado em consideração em nossas análises. Nossos resultados mostram que as características delimitadoras de Peripatus são 
compartilhadas com as espécies de Epiperipatus e vice-versa. Por exemplo, machos de Peripatus possuem papilas crurais em mais de dois pares de pernas pregenitais. No entanto, machos de Epiperipatus cratensis Brito et al., 2010, Epiperipatus diadenoproctus Oliveira et al., 2011 e Epiperipatus solorzanoi (Morera-Brenes \& Monge-Nájera, 2010) n. comb. podem apresentar papilas crurais em três pares de pernas pregenitais. Além disso, a espécie nova Epiperipatus [whitehead2] [ony 125] n. sp. apresenta as papilas crurais em quatro pares de pernas pregenitais.

Em geral, as espécies de Epiperipatus apresentam poucas escamas enfileiradas verticalmente nas duas partes das papilas principais: três ou menos escamas na peça apical (na região posterior) e até dez escamas na base (aproximadamente). Entretanto, Epiperipatus bouvieri (Fuhrmann, 1913) n. comb. apresenta doze ou mais escamas enfileiradas na base e três escamas na região posterior da peça apical. Nossos resultados mostram que não há evidência morfológica para separação de Epiperipatus e Peripatus. Embora, haja suporte molecular para Epiperipatus, este gênero não apresentou suporte morfológico. Entretanto, a maioria das espécies de Epiperipatus apresentam menos de cinco escamas na peça apical (na região posterior), com exceção de E. solorzanoi. Por isso, com a reinterpretação dos caracteres sugeridos por Read (1988a) poderíamos separar de Epiperipatus e Peripatus da seguinte forma: (1) Epiperipatus: a base da papila primária apresenta de quatro a dezoito escamas enfileiradas. A região posterior da peça apical apresenta de uma a quatro escamas enfileiradas. A exceção é E. solorzanoi, que possui dois tamanhos de papilas principais e as pequenas papilas principais possivelmente foram confundidas com papilas acessórias (Morera-Brenes \& Monge-Nájera 2010). (2) Peripatus: a base da papila primária apresenta mais de quinze escamas enfileiradas. A região posterior da peça apical apresenta quatro ou mais escamas enfileiradas.

Com relação aos caracteres morfológicos sugeridos por Oliveira et al. (2012, 2013, 2015), não conseguimos estudar adequadamente os arcos antenais e suas papilas sensoriais, a morfologia do tegumento ventral e a estrutura dos embriões. Examinamos espécimes de diversas coleções e fixados de diversas maneiras. Além disso, o método de fixação que adotamos não permitiu bons resultados na preservação das estruturas examinadas por Oliveira et al. (2012, 2013 e 2015). Dados embriológicos podem ser bons, mas dependem da amostragem, que em nosso caso foi irregular entre as espécies examinadas neste estudo. Assim, nos estudos filogenéticos de Peripatidae é mais eficiente buscar por caracteres amplamente difundidos que investir por grandes amostragens de uma mesma espécie.

Por outro lado, a utilização de sequências de DNA inaugurou uma nova era de descoberta de espécies que permitiu a identificação de espécies crípticas (Brickford et al. 2007). Peripatidae se beneficiou com as novas abordagens dentro da sistemática filogenética, devido à complementaridade entre os diferentes tipos de informação. Por exemplo, dados genéticos sugerem que essa família 
surgiu antes da Gondwana (Murienne et al. 2014). Além disso, esses dados também revelam uma grande diversidade de espécies em Peripatidae (Oliveira et al. 2012, 2013, 2015).

Dados moleculares são mais rápidos de serem obtidos que dados morfológicos. Proporcionalmente, os dados moleculares contribuíram muito mais que os dados morfológicos devido ao volume de informação obtida para cada conjunto de dados. Por exemplo, na análise de MP exclusiva para os dados morfológicos, o consenso das 100 árvores mais parcimoniosas não apresenta resolução em Peripatidae (ver Capítulo 2). Com nossos resultados, Epiperipatus só pode ser delimitado morfologicamente a partir de simplesiomorfias, embora seja suportado por muitas sinopormofias moleculares.

Embora não suportado pela morfologia, Epiperipatus é claramente suportado por todos os marcadores e diversas sinapormafias moleculares. Epiperipatus apresenta sinapomorfias não ambíguas para COI 12S e 16S, e 18S. Dessa forma, comprovou-se a superioridade dos dados moleculares em relação aos morfológicos em Peripatidae. Apesar disso, alguns clados são suportados por ambos os conjuntos de dados, embora alguns clados sejam suportados por poucas transformações moleculares em relação a morfologia, (por exemplo, E. solorzanoi. Ver Capítulo 2, tabela S.3). Contudo, fica evidenciada a vantagem de se utilizar mais de uma fonte de dados.

\section{III - EPIPERIPATUS É MONOFILÉTICO?}

A análise de evidência total demonstrou que Epiperipatus é parafilético, pois nesse gênero estão inseridas P. bouvieri, P. solorzanoi, P. hitoyensis e C. sucuriuensis. No entanto, transferimos essas espécies para o gênero Epipepatus e propomos as novas combinações E. sucuriuensis n. comb., E. bouvieri n. comb. e E. hitoyensis n. comb., o que torna Epiperipatus monofilético. Tornar Epiperipatus monofilético trouxe como consequência imediata a descrição de cinco espécies novas, sem aumentar o número de gêneros neotropicais. Nesse contexto, o fraco suporte morfológico nos resultados das análises de MP não só é evidencia da morfologia conservativa em Peripatidae, como também corrobora a diversidade concentrada em poucos gêneros, sendo Epiperipatus um deles.

As famílias Peripatopsidae e Peripatidae são monofiléticas, porém Peripatidae só tem suporte molecular (ver Capítulo 2, Figura 2). O clado Neotropical de Peripatidae (clado D+E) é monofilético e suportado por duas sinapomorfias não únicas (ver Capítulo 2, Figura 2 e a Lista de Caracteres):

- caráter 1 (padrões na região dorsal do corpo), estado 1 (presente)

- caráter 2 (losangos dorsais) estados 0 (ausente) e 1 (presente) 
Oroperipatus apresenta duas sinapomorfias únicas, homoplásticas e uma sinapomorfia exclusiva (ver Capítulo 2, Figura 2 e a Lista de Caracteres):

- caráter 20 (número de papilas retrolaterais do pé), estado 1 (duas)

- caráter 27 (posição das papilas urinárias) estado 1 (deslocado para posição retrolateral do terceiro arco de sola).

- caráter 24 (forma do terceiro arco de sola do quarto e quinto para de pernas), estado 2 (dividida em dois fragmentos desiguais)

Entretanto, Epiperipatus não é sustentado por caracteres morfológicos, e sua delimitação morfológica foi feita com base em simplesiomorfias.

As relações filogenéticas observadas neste estudo corroboram a hipótese de relação entre os gêneros americanos e africanos sugerida por Bouvier (1905) e testada por Murienne et al. (2014). Todos os resultados filogenéticos apresentados sugerem o grupo africano (representado por $M$. tholoni) como grupo-irmão de um clado Neotropical, monofilético. Este clado, por sua vez, é claramente dividido em dois clados correspondentes aos grupos "andícola" e "caraiba" de onicóforos, representados por Oroperipatus e Epiperipatus respectivamente.

A maior contribuição deste estudo foi realizar uma avaliação explícita do posicionamento filogenético de Epiperipatus, utilizando o método de evidência total. Além disso, o presente estudo também enfatiza a importância dos dados moleculares para os estudos filogenéticos em Peripatidae, devido a pouca variação morfológica observada dentro dessa família. Este estudo encontrou clados suportados por diferentes fontes de dados. Clados suportados por uma única fonte de dados podem ser usados para justificar o uso de fontes de dados diversas. Clados suportados por poucos caracteres morfológicos podem ser suportados por transformações moleculares. Por exemplo, Epiperipatus é suportado por muitas transformações moleculares e nenhum caráter morfológico.

O tamanho da amostra também é importante para a qualidade dos resultados. Quanto maior a base de dados, maior será a quantidade de informação agregada aos resultados. A amostragem utilizada neste estudo, com a inclusão da espécie-tipo de Epiperipatus, foi essencial para detectar os problemas taxonômicos desse gênero e realizar os atos taxonômicos propostos neste estudo. Além de Epiperipatus, pelo menos outro três gêneros merecem revisões filogenéticas e são eles: Macroperipatus, Peripatus e Speleoperipatus. Esses três gêneros apresentam problemas taxonômicos semelhantes aos observados inicialmente em Epiperipatus. Por fim, este estudo é encorajador de mais revisões sistemáticas dentro de Peripatidae, com a inclusão da maior quantidade amostral possível e de diferentes fontes de dados. 
Bickford D., Lohman D. J., Sodhi N. S., N. P. K., Meier R., Winker K., Ingram K. \& Das I. 2007. Cryptic species as a window on diversity and conservation. Trends in Ecology \& Evolution, 22:148-155.

Daniels, S. \& Ruhberg, H. 2010. Molecular and morphological variation in a South African velvet worm Peripatopsis moseleyi (Onychophora, Peripatopsidae): evidence for cryptic speciation. Journal of Zoology, 282 (3): 171-179.

Lacorte, G. A., Oliveira, I. S .F. \& Cleusa, G. 2011. Phylogenetic relationships among the Epiperipatus lineages (Onychophora: Peripatidae) from the Minas Gerais State, Brazil. Zootaxa, 65: 57-65.

Morera-Brenes, B. \& Monge-Nájera, J. 2010. A new giant species of placented worm and the mechanism by which onychophorans weave their nets (Onychophora: Peripatidae). Revista de Biología Tropical, 58(4), 1127-1142.

Murienne, J., Daniels, S. R, Buckley, T. R., Mayer, G. \& Giribet, G. 2014. A living fossil tale of Pangaean biogeography. Proceedings of the Royal Society B: Biological Sciences, 281: 20132648. http://dx.doi.org/10.1098/rspb.2013.2648.

Oliveira, I. S., Lacorte, G. A., Fonseca, C. G., Wieloch, A. H. \& Mayer, G. 2011. Cryptic Speciation in Brazilian Epiperipatus (Onychophora: Peripatidae) Reveals an Underestimated Diversity among the Peripatid Velvet Worms. PLoS ONE, 6: 1-13.

Oliveira, I. S., Franke, F. A., Hering, L., Schaffer, S. \& Rowell, D. M. 2012. Unexplored Character Diversity in Onychophora (Velvet Worms): A Comparative Study of Three Peripatid Species. PLoS ONE 7 (12): e51220.

Oliveira, I. S., Schaffer, S., Kvartalnov, P. V., Galoyan, E. A., Palko, I. V., Weck-Heimann, A., Geissler, P., Ruhberg, H. \& Mayer, G. 2013. A new species of Eoperipatus (Onychophora) from Vietnam reveals novel morphological characters for the South-East Asian Peripatidae. Zoologischer Anzeiger, 252 (4): 495-510. http://dx.doi.org/10.1016/j.jcz.2013.01.001

Oliveira, I. S., Lacorte, G. A., Weck-Heimann, A., Cordeiro, L. M., Wieloch, A. H. \& Mayer, G. 2015. A new and critically endangered species and genus of Onychophora (Peripatidae) from the Brazilian savannah - a vulnerable biodiversity hotspot. Systematics and Biodiversity, 13: 211-233. 


\title{
ABSTRACT \\ Systematic and Phylogenetic analysis of Epiperipatus Clark, 1913 (Onychophora: Peripatidae) based on molecular and morphological data
}

PhD candidate: Cristiano Sampaio Costa

Advisor: Ricardo Pinto da Rocha

Coadvisor: Fernando Portella de Luna Marques

\begin{abstract}
PhD Thesis submitted to the Graduate Program of Zoology of the Institute of Biosciences, University of São Paulo - USP, as part of the requisites for the completion of a PhD degree in Biological Sciences.
\end{abstract}

The "caraibes" onychophorans present both a large diversity and weakly defined genera. Epiperipatus Clark, 1913 is the largest genus, but it has not been revised so far. This genus is herein incorporated into the currently most comprehensive molecular phylogenetic analysis of Peripatidae, assisted by morphology. Four markers were used: cytochrome $c$ oxidase subunit I (COI), 12S rRNA, 16S rRNA (mitochondrial) and 18S rRNA (nuclear). Moreover, 33 morphological characters were obtained. The dataset was used in two Maximum Parsimony (MP) and one Maximum Likelihood (ML) analyses. In a total of 175 specimens of Onychophora, nine genera and twenty-nine species were examined, eighteen of them belonging to Epiperipatus. We adopted as work hypothesis the MP based on total evidence.

The result showed that morphological by itself cannot be used to resolve the phylogenetic relationships of this group, because the number of characters is smaller than the number of terminals examined. Here, Peripatidae was based on molecular data and this conflicts with the characters traditionally used to define genera in the family. It means that clades supported by molecular data shows high morphological disparity which might be reflected on the adaptation to different environments in the Caribbean clade.

Also, the result suggests that Epiperipatus seems to be not monophyletic, as it includes others genera and these genera should be synonymized. Epiperipatus presented stable relationships across three clades of Neotropical onychophorans, but it was observed the unstable position of Epiperipatus 
edwardsii (Blanchard, 1847) and four groups also. To reconcile Epiperipatus systematics with the phylogeny, the monotypic genera Principapillatus Oliveira et al., 2014 and Cerradopatus Oliveira et al., 2015 should be considered as junior synonyms of Epiperipatus. Hence, the new combinations were proposed: Epiperipatus hitoyensis (Oliveira et al., 2012) n. comb. and Epiperipatus sucuriuensis (Oliveira et al., 2015) n. comb.. Moreover, the new species Epiperipatus [sp1] n. sp., Epiperipatus [sp2] n. sp., Epiperipatus [sp10] n. sp., Epiperipatus [sp16] n. sp. and Epiperipatus [sp17] n. sp. were presented and described here. Rooting the Onychophora phylogeny in Peripatopsidae resulted in the Neotropical group as the sister group relationship to the African species, and an apparently ancestral group from Asia. The demonstrated Epiperipatus monophily confirmed its widespread distribution, in the same way as Peripatus. Both are recorded from Central America to Brazil. However, in Brazil, while Peripatus occurs only until the Central-West region, Epiperipatus is found in all Brazilian territories, except in the South region. 


\title{
RESUMO
}

\section{Sistemática e análise filogenética de Epiperipatus Clark, 1913 (Onychophora: Peripatidae) baseada em dados moleculares e morfológicos}

\author{
Doutorando: Cristiano Sampaio Costa \\ Orientador: Ricardo Pinto da Rocha \\ Coorientador: Fernando Portella de Luna Marques
}

\begin{abstract}
Este resumo, submetido ao Programa de Pós-Graudação em Zoologia do Instituto de Biociências, da Universidade de São Paulo, é parte dos requisitos necessários para a conclusão do grau de Doutor em Ciências Biológicas.
\end{abstract}

O grupo de onicóforos "caraíbas" apresenta grande diversidade de espécies, mas também gêneros fracamente delimitados. Epiperipatus Clark, 1913 é o maior dos gêneros neotropicais de Onychophora, mas ainda não sofreu revisão taxanômica. Este gênero foi incorporado no presente estudo, que contemplou o mais abrangente conjunto de dados moleculares, assistido por dados morfológicos. Quatro marcadores moleculares foram utilizados: cytochrome $c$ oxidase subunit I (COI), 12S rRNA, 16S rRNA (mitochondriais) e 18S rRNA (nuclear). Além disso, trinta e três caracteres morfológicos foram levantados. A base de dados foi submetida a duas análises de Máxima Parcimônia (MP) e uma de Máxima Verossimilhança (ML). No total foram examinados 175 espécimes, cobrindo nove gêneros e vinte e nove espécies, dezoito delas pertencentes a Epiperipatus.

Foi adotado como hipótese de trabalho o cladograma resultante da análise de evidência total que contemplou os dados moleculares e morfológicos. O resultado mostrou que os dados morfológicos não são capazes de resolver por si só as relações internas de Peripatidae, pois o número de caracteres morfológicos é menor que o número de terminais examinados. Peripatidae é suportado por dados moleculares e isso é conflitante com a delimitação morfológica tradicional dos gêneros da família. Isso demonstra que clados suportados por dados moleculares mostram elevada disparidade morfológica, que pode estar relacionada a adaptação a diferentes ambientes do clado Neotropical.

Além disso, o resultado também sugeriu Epiperipatus como parafilético, pois engloba outros gêneros que devem ser sinonimizados. Epiperipatus apresentou estabilidade em três clados 
neotropicais, apesar de que Epiperipatus edwardsii (Blanchard, 1847) e outros quatro grupos mostraram posição instável. Para reconciliar a sistemática e a filogenia de Epiperipatus, os gêneros monotípicos Principapillatus Oliveira et al., 2014 e Cerradopatus Oliveira et al., 2015 devem ser considerados sinônimo-junior de Epiperipatus. Consequentemente, as novas combinações foram propostas: Epiperipatus hitoyensis (Oliveira et al., 2012) n. comb. e Epiperipatus sucuriuensis (Oliveira et al., 2015) n. comb.. Além disso, foram apresentadas e descritas as espécies novas Epiperipatus [sp1] n. sp., Epiperipatus [sp2] n. sp., Epiperipatus [sp10] n. sp., Epiperipatus [sp16] n. sp. e Epiperipatus [sp17] n. sp.. O enraizamento da filogenia de Onychophora em Peripatopsidae resultou no grupo Neotropical como grupo-irmão do grupo africano, e um aparente ancestral Asiático. A demonstrada monofilia de Epiperipatus confirmou sua larga distribuição, da mesma forma que Peripatus. Ambos os gêneros ocorrem da América Central ao Brasil. Entretanto, no Brasil enquanto Peripatus ocorre apenas no centro-oeste desse país, Epiperipatus é encontrado em quase todo o território desse país, com exceção da região sul. 